\title{
Taideverokirja Verot taiteessa ja taiteet verotuksessa
}

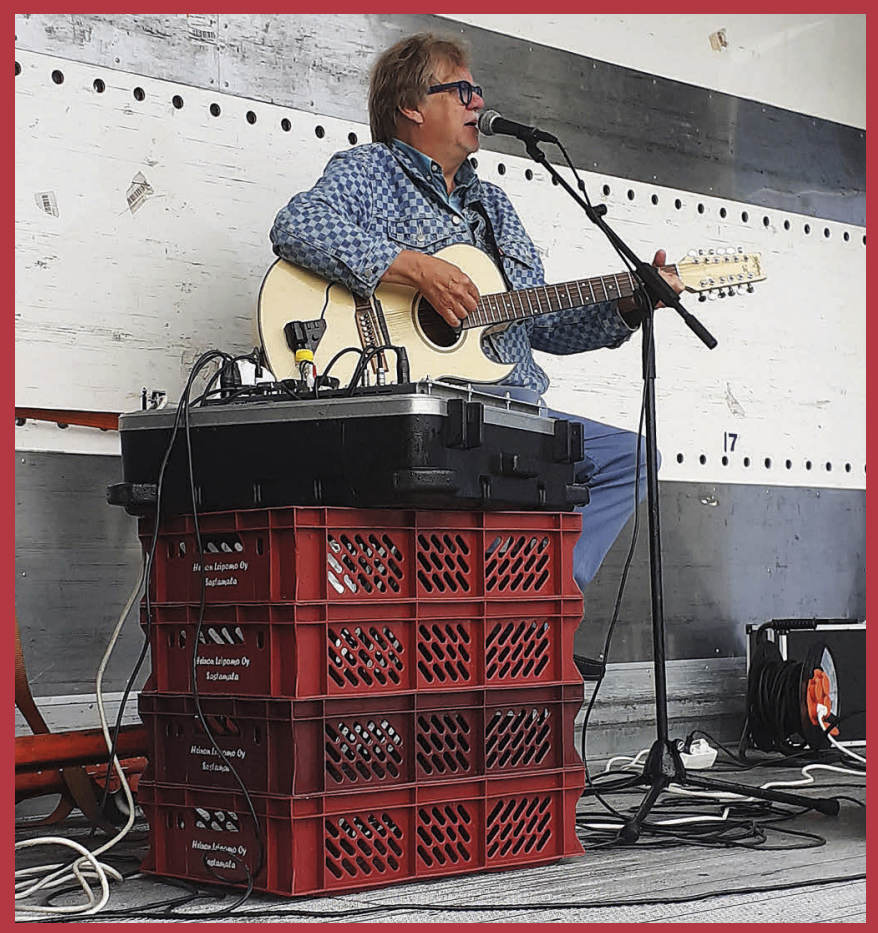

Esko Linnakangas 



\section{Taideverokirja}





\section{Esko Linnakangas}

\section{Taideverokirja Verot taiteessa ja taiteet verotuksessa}




\section{$\approx$ \\ HELDA Open Books}

Alkuperäisen teoksen on julkaissut Esko Linnakangas

vuonna 2021. Tämän version, joka on

samansisältöinen alkuperäisen julkaisun kanssa, on

julkaissut Helsingin yliopiston kirjasto Esko Linnakankaan

luvalla vuonna 2021.

ISBN: 978-952-69372-4-3 (PDF)

DOI: $10.31885 / 9789526937243$

Tämä teos on julkaistu Creative Commons-lisenssillä CC BY (4.0)

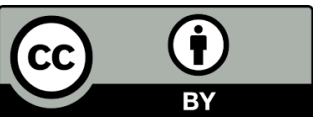

Copyright (C) 2021 Esko Linnakangas

ISBN 978-952-69372-3-6 (nid.)

ISBN 978-952-69372-4-3 (PDF)

Kansi ja sivunvalmistus: NotePad

Kirjapaino: Grano Oy

Helsinki 2021 


\section{Parannuksentekoa}

Lohjalainen kansakoulunopettaja, joka oli hyvin musikaalinen, totesi vanhemmilleni, että tätä poikaa ei kannata edes yrittää oppikouluun, koska ei riitä, että pärjää laskennossa. Opettajan pettymykseksi läpäisin pääsykokeen. Sitten keskikoulussa paras arvosanani oli 10, joka annettiin käytöksestä. Uskonnosta ja historiasta tuli alkuaikoina arvosanaksi 10 (uskonto 5 + historia 5). Myöhemmin heikoimmat arvosanat sain urheilussa, laulussa, kuvaamataidossa ja suomen kielessä.

Parannuksenteon urheilussa ja suomessa aloitin ylioppilaskirjoituksissa valitsemalla äidinkielen kokeen teemaksi urheilun yliarvostamisen. Siitä tuli jo kiitosta latinaksikin. Urheilun parissa jatkoin Helsingin yliopistossa tekemällä urheiluverotuksesta väitöskirjan. En edelleenkään ollut urheilumiehiä, mutta vastaväittäjäni professori Jaakko Voipio arveli kirjani esipuheessa kiiteltyjen urheilujohtajien vaikuttaneen alalle myönteisiin kannanottoihini.

Lapin yliopistossa, jossa on nykyisin myös taiteiden tiedekunta, siirryin urheilusta taiteiden pariin tekemällä kirjan "Elokuvaverotus". Timo Viherkenttä vertasi kirja-arvostelussa minua Alpo Suhoseen, joka noihin aikoihin siirtyi jääkiekkovalmentajasta teatterinjohtajaksi.

Uskonnon ja historian kouluaikaisten tietojen vajavuutta olen eläkkeelle jäätyäni paikkaillut laatimalla professori Leila Juannon kanssa teokset "Verojen historia - Synty, kehitys, kuolema, ylösnousemus, reinkarnaatio" ja "Synti- ja haittaverokirja - Anekaupasta paheveroihin ja kompensaatiomaksuihin".

Musikaalisuuteni arvioitiin koulussa kutoseksi, joten en ole sittemmin paljon lauleskellut. Aikuisiällä tanssikurssilla opin lähinnä sen, 
mitä tarkoittaa "sujuminen kuin tanssi": se on jotain tosi vaikeaa. Nyt palaan sävel- ja kuvataiteisiin ja laajennan tarkastelun muihinkin taiteenlajeihin.

Tämä tutkimus sai alkunsa pääsiäisviikolla 2021, kun istuin autossa ruokakaupan parkkipaikalla. Vuosia kestäneiden murreopintojen perusteella jo tiesin kaupan olevan Sastamalan Häijäässä eikä Häijäällä. Radiosta tuli Mikko Alatalon "Yhdentoista virran maa”, jonka yksi kohta antoi innoituksen tutkia taiteen ja verotuksen suhdetta:

\footnotetext{
"Se maa, jossa kasvoin, se on vihan maa.

Siellä vihataan nälkää ja lakkoilijaa.

Siellä vihataan herraa, ei omistajaa,

ei enää niin ryssää, aina verottajaa.”
}

Mikko Alatalo on esittänyt kymmenkunta muutakin veropitoista laulua; se taitaa olla Suomen ennätys. Ottamassani kansikuvassa Alatalo esiintyy Sastamalassa Suodenniemi-viikolla heinäkuussa 2021.

Taiteen verotuksen aikaisemmista tutkimuksista voidaan mainita professori Edward Anderssonin ja taidemaalari, varatuomari Katy Gyllströmin teos "Kuvataiteilijan verotuksesta" (1982) sekä Pauli Rautiaisen väitöskirja "Kuvataiteilijan oikeudellinen asema: Ammattimaista taiteellista toimintaa rajoittava ja edistävä oikeussääntely" (2012). Jälkimmäinen tutkimus on taustoiltaan ja syntyprosessiltaan minun tutkimukseni vastakohta. Rautiainen aloitti taiteiden tutkijana, ja taiteilla on ollut hänen elämässään tärkeä rooli. Hän on siis taiteiden sisäpiiristä, minä sen sijaan tutkin taiteen ja verotuksen suhdetta ulkopuolisen silmin. Käsillä olevassa kirjassa selvitetään juridiikan ohella sitä, miten verotus on näkynyt ja näkyy taiteissa. Jostakin syystä sitä ei ole aikaisemmin juuri lainkaan tutkittu.

Tämä tutkimus julkaistaan sekä painettuna kirjana että kaikille vapaana sähköisenä versiona. Harkinnassa oli äänikirjakin, jossa olisin laulanut otteita kirjan verobiiseistä. Äänikirjasta kuitenkin luovuttiin mm. tekijänoikeudellisten kysymysten vuoksi ja siksi, että useimmat kappaleet ovat kokonaisina kuunneltavissa YouTubessa.

Monet taiteellisetkin henkilöt - joiden nimiä en tässä paljasta - ovat ystävällisesti valistaneet minua ja rikastuttaneet kirjaa kommenteillaan 
ja vinkeillään. Kaikenlaisesta avusta tässäkin hankkeessa kiitän omaa kustannustoimittajaani Taija Haapaniemeä. Hän on myös ottanut kirjan takakannen valokuvat; toisessa on lämpimästi pukeutunut köyliöläinen verokapinallinen Lalli ja toisessa alaston pirkkalainen veronkantaja Tammerkosken sillalla.

Karkussa suomalaisen kirjallisuuden päivänä 10.10.2021

Esko Linnakangas

finanssioikeuden emeritusprofessori

esko.linnakangas@professori.fi 



\section{Sisällys}

PARANNUKSENTEKOA

\section{OSA}

\section{TUTKIMUKSEN TAUSTA, TARKOITUS JA}

\section{TOTEUTUS ............................................................ 19}

1.1 Taide, taiteenlajit ja taiteilijat................................ 19

1.1.1 Taidekäsite ja käsitetaide................................... 19

1.1.2 Taiteilijat, viihde ja viihdetaiteilijat................... 21

1.1.3 Taiteilijoista erikoisina verovelvollisina - vertailua urheilijoihin ............................................. 22

1.2 Taiteen sääntely ja taiteilijan oikeudet................... 25

1.2.1 Perustuslaki ja taidelainsäädäntö ....................... 25

1.2.2 Taloudelliset ja moraaliset tekijänoikeudet tekijänoikeuslain mukaan ............................... 26

1.3 Vero ja verovelkasuhteen osapuolet....................... 27

1.3.1 Veron käsite.................................................. 27

1.3.2 Verosubjektit, vero-objektit ja verolajit .............. 27

1.3.3 Verotuksen toimittamisen ja veronkannon kehitys 28

1.3.3.1 Välitön verotus................................... 28

1.3.3.2 Tullit ja muu kulutusverotus ............... 33

1.3.3.3 Yhteenvetoa ….................................. 35 
1.3.4 Verosanastoa eri kielissä.................................... 35

1.3.4.1 Vero............................................... 35

1.3.4.2 Muuta verosanastoa .......................... 36

1.4 Taideverokirjan tarkoitus ja toteutus...................... 37

\section{|| OSA}

2 VEROTEEMA TAITEISSA

2.1 Tehtävän tarkentaminen ja jäsentely sekä aineiston hankinta

2.2 Taulut, patsaat, muistomerkit ja rakennukset........... 40

2.3 Romaanit, elokuvat, rikossarjat ja kuunnelmat......... 42

2.3.1 Suomalaisia romaaneja, näytelmiä ja elokuvia ..... 42

2.3.2 Ulkomaisia romaaneja ja elokuvia ..................... 45

2.3.3 Kuunnelmat ................................................. 47

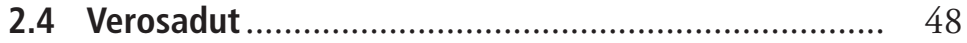

2.4.1 Mitä ovat sadut?........................................... 48

2.4.2 Zacharias Topelius.......................................... 48

2.4.3 Jonathan Swift .............................................. 49

2.4.4 Astrid Lindgren ja Janosch.............................. 50

2.5 Piirrokset, sarjakuvat ja sketsit............................. 53

2.5.1 Pilapiirrokset ja verokarhu ............................... 53

2.5.2 Verotarkastajat, verokonsultit ym..................... 55

2.6 Runot............................................................ 56

2.6.1 Pyhän Henrikin surmavirsi ja Kalevala .............. 56

2.6.2 Nuijasota ja Kaarlo Kramsu ............................. 58

2.6.3 Eino Leinon runot ...................................... 58

2.6.4 Veroaiheisia käyttörunoja .............................. 60

2.7 Laulut ................................................................ 64

2.7.1 Vallankumous- ja työväenlaulut ........................ 64

2.7.2 Pohjois-Amerikan 1900- ja 2000-lukujen verolauluja.................................................... 68

2.7.2.1 Country ja rap................................... 68

2.7.2.2 1900-luku.......................................... 69

2.7.2.3 2000-luku.......................................... 71 
2.7.3 Brittiläisiä verolauluja 1960- ja 1980-luvulta ....... 75

2.7.3.1 The Kinks.......................................... 75

2.7.3.2 The Beatles ......................................... 77

2.7.3.3 Billy Bragg ................................... 78

2.7.4 Suomalaisia verolauluja .................................. 78

2.7.4.1 Kansanlauluista ................................ 78

2.7.4.2 Protestilaulujemme teemoista............... 79

2.7.4.3 Eino Virtanen ja Lasse Kuusela............. 80

2.7.4.4 Irwin Goodman ................................ 80

2.7.4.5 Mikko Alatalo ................................... 85

2.7.4.6 Juha Vainio ........................................ 88

2.7.4.7 Sleepy Sleepers .................................. 89

2.7.4.8 Klamydia ja Iglu ............................... 90

2.7.4.9 Veikko Lavi (Pertti Koivula) sekä Heikki Kinnunen ja Satu Silvo ........................ 91

2.7.4.10 Vilperin perikunta (1999) .................... 95

2.7.4.11 Veropakolaislauluja (Julle ja Hilipiliboys, Turo's Hevi Gee, Petri Hankonen) ......... 96

2.7.4.12 Alkoholi ja verotus, autovero, Yle-vero ja lentovero.............................................. 98

2.7.4.13 Tullilauluista ................................... 100

2.7.4.14 Vaihtoehtoinen joululaulu sekä uutta räppiä ja punk-rockia........................... 101

2.7.5 Henkivero (poll tax) protestilauluissa ................. 104

2.7.5.1 Henkiveron käsite, historia ja suhde muihin veroihin ................................. 104

2.7.5.2 Thatcher ja poll tax verolauluissa .......... 106

2.7.6 Venäläinen lapsettomuusverolaulu..................... 107

2.7.7 Viron, Ruotsin ja Norjan 2000-luvun verolauluja.................................................... 108

2.7.8 Saksan-, ranskan- ja espanjankielisistä verolauluista ............................................... 110

2.8 Verolajeittainen tarkastelu ................................. 111 


\section{OSA}

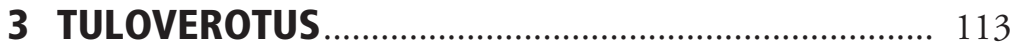

3.1 Tuloverotuksen synty ja kehitys ................................. 113

3.2 Varallisuusverosta ja kiinteistöverosta ...................... 115

3.2.1 Varallisuusveron historia..................................... 115

3.2.2 Taide-esineet kumotussa varallisuusverotuksessa... 117

3.2.3 Kiinteistövero ………………………………..... 118

3.2.3.1 Kiinteistöveron historiasta...................... 118

3.2.3.2 Yleishyödyllisten yhteisöjen asema kiinteistöverotuksessa.............................. 119

3.3 Tulot ja menot taiteesta .............................................. 120

3.3.1 Tulojen veronalaisuus ja tulolähde........................ 120

3.3.2 Tulolajit ……………………….................... 121

3.3.2.1 Ansiotulot ja pääomatulot ...................... 121

3.3.2.2 Aineettomista oikeuksista saatujen tulojen tulolaji..................................... 122

3.3.3 Verovapaita tuloja …………………………..... 123

3.3.3.1 Stipendit ja apurahat.............................. 123

3.3.3.2 Tunnustuspalkinnot................................ 125

3.3.3.3 Kilpailupalkinnot ................................ 127

3.3.3.4 Taide verovapaana henkilökuntaetuna.... 129

3.3.3.5 Elokuvatuotantotuki.............................. 133

3.3.4 Taiteilijan tulonhankkimismenojen vähennyskelpoisuus............................................ 134

3.4 Ajallinen kohdistaminen .......................................... 138

3.4.1 Tulojen ja menojen jaksotuksesta yleensä............. 138

3.4.2 Aineettoman hyödykkeen hankintameno ja sen vähentäminen ...................................................... 140

3.4.3 Tappiontasaus...................................................... 142

3.4.3.1 Tappiontasausjärjestelmä......................... 142

3.4.3.2 Luonnolliset henkilöt............................. 142

3.4.3.3 Yhtiöt ……………………………..... 143

3.4.4 Tulontasaus .................................................... 144

3.4.5 Menovarausta ja taiteilijatiliä koskevat ehdotukset................................................. 147 
3.4.6 Ruotsin taiteilijatili ja Suomen urheilutulojen rahastointi

3.5 Veromäärä ja progressio 154

\subsection{Henkilöllinen kohdistaminen ja taidetoiminnan} yhtiöittäminen.

3.6.1 Verosuunnittelu ja veronkiertäminen lähikäsitteineen

3.6.2 Palkkiosta luopuminen ja palkkion luovuttaminen - puu ja hedelmät -oppi

3.6.3 Henkilöyhtiöiden verotusaseman ja sivuuttamiskäytännön kehitys 160

3.6.4 Taiteilijoiden osakeyhtiöt 161

3.6.4.1 Osakeyhtiön verotusaseman kehitys....... 161

3.6.4.2 Osakeyhtiöiden sivuuttamiskäytännön kehitys

3.6.4.3 Tekijänoikeustuloja koskevaa oikeuskäytäntöä

3.6.4.4 Tekijänoikeuksien luovutus määräajaksi musiikintekijän yhtiölle

3.7 Taiteilijoiden kansainvälinen tuloverotus

3.7.1 Kaksinkertaisesta verotuksesta ja vajaaverotuksesta

3.7.2 Verotusvaltion määräytyminen

3.7.2.1 Kansallinen lainsäädäntö ja verosopimukset

3.7.2.2 Taiteilija-artikla verosopimuksissa 174

3.7.2.3 Rojaltit

3.7.3 Ulkomaisten taiteilijoiden alhainen lähdevero...... 180

3.7.4 Taiteilijat avainhenkilöiden lähdeverolaissa ......... 181

3.8 Taiteen tukijoiden tuloverotus

3.8.1 Taidetta tukemaan perustetut yhteisöt

3.8.2 Taidemenot yritysten luonnollisina vähennyksinä

3.8.2.1 Vaihto-omaisuus 
3.8.2.2 Käyttöomaisuus................................. 185

3.8.2.2.1 Irtain kuluva

käyttöomaisuus ................... 185

3.8.2.2.2 Taide-esineet kulumattomana käyttöomaisuutena.............. 186

3.8.2.2.3 Taide rakennuksen osana...... 186

3.8.2.3 Suhdetoiminta- yms. menot ................ 186

3.8.2.4 Yhteisön lahjoitusvähennys ................. 187

3.8.2.5 Luonnollisen henkilön lahjoitusvähennys 188

4 PERINTÖ- JA LAHJAVEROTUS

4.1 Perintö- ja lahjaveron historiasta............................ 190

4.2 Taidesäätiöiden ja -yhdistysten asema .................... 191

4.3 Taideteokset tavanomaisena koti-irtaimistona......... 192

4.4 Tekijänoikeudet oikeuskäytännössä ....................... 193

5 HUVI- JA ELOKUVAVEROTUS .................................. 197

5.1 Huvien verotus ennen Suomen itsenäistymistä ........ 197

5.2 Itsenäistymisestä 1960-luvun alkuun...................... 198

5.3 1960- ja 1970-luvut............................................ 199

5.4 Huviverotuksen kumoaminen 1980-luvun alussa...... 200

5.5 Elokuvaveron hiipuminen 1980-luvulla ja

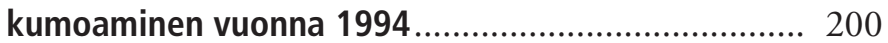

6 ARVONLISÄVEROTUS JA TULLIVEROTUS............... 202

6.1 Yleisen kulutusverotuksen historiasta .................... 202

6.2 Pakollinen ja vapaaehtoinen arvonlisäverovelvollisuus...................................... 203

6.3 Esiintymispalkkioiden ja tekijänoikeuskorvausten arvonlisäverollisuus ............................................... 204

6.3.1 Verottomat ja verolliset suoritukset.................... 204

6.3.2 Esiintyvien taiteilijoiden vapaaehtoinen verovelvollisuus............................................. 209

6.4 Taide-esineiden marginaaliverotus ........................ 211 
6.5 Yleinen ja alennettu verokanta ............................... 212

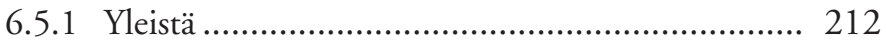

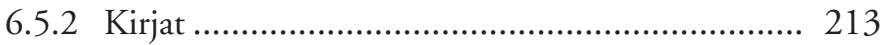

6.5.3 Tekijänoikeusjärjestön saama tekijänoikeuteen liittyvä korvaus .......................................... 213

6.5.4 Taide-esineet.............................................. 213

6.5.5 Kulttuuritilaisuuksien sisäänpääsymaksut ........... 214

6.5.6 Esiintyvien taiteilijoiden palkkiot...................... 215

6.6 Kulttuuri- yms. palvelujen myyntimaa..................... 215

6.7 Tulliverotus....................................................... 216

6.7.1 Tulliverotuksen historiaa................................. 216

6.7.2 Taideteosten tulli ........................................ 217

7 ARVONIMIVERO ...................................................... 219

7.1 Sääntelyn historiasta .......................................... 219

7.2 Taiteilijoille sopivat arvonimet ja niiden hinta ........ 220

8 VEROJEN VANHENTUMINEN JA ANTEEKSIANTO... 221

\section{OSA}

\section{VEROTUKSEN TAIDESUHTEEN KEHITYS JA}

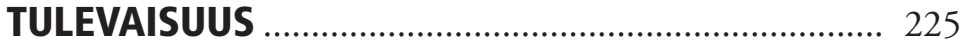

9.1 Taiteen julkisen tukemisen perustelut ...................... 225

9.2 Taiteen julkisen rahoituksen historiasta Suomessa 1830-luvulta 2020-luvulle ....................................... 228

9.3 Verotuksen tavoitteista............................................ 230

9.4 Verotuet sekä niiden edut ja haitat verrattuna suoriin tukiin

9.5 Taiteen asema verotusta uudistettaessa ................... 232

9.6 Veropoliittisen taiteen tulevaisuus - maailman onnellisin kansa 
LIITE: tekijänoikeuksien yksinomaisen

käyttöoikeuden luovuttaminen määräajaksi

musiikintekijän yhtiölle................................................... 235

TUTKIMUSKIRJALLISUUTTA ………………………...... 253

OIKEUSTAPAUSHAKEMISTO ......................................... 256

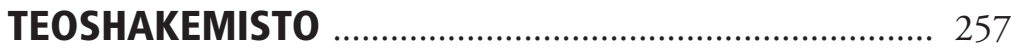

TAITEILIJAHAKEMISTO …………………………........ 261

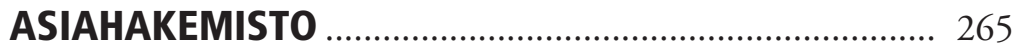




\section{Lyhenteitä}

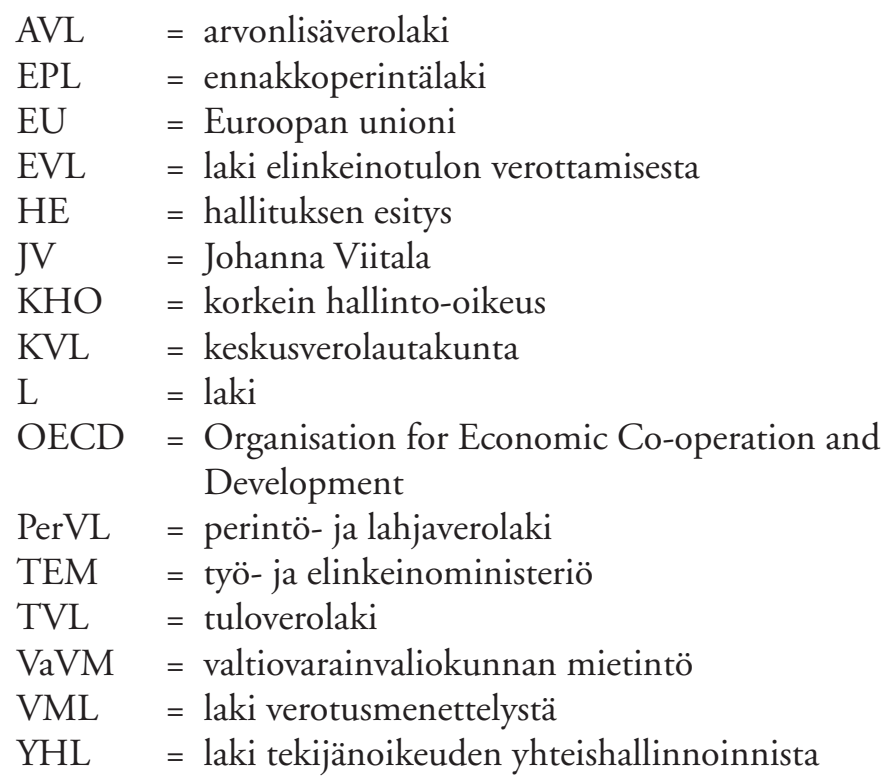





\section{I \\ osa}

\section{Tutkimuksen tausta, tarkoitus ja toteutus}

\subsection{Taide, taiteenlajit ja taiteilijat ${ }^{1}$}

\subsubsection{Taidekäsite ja käsitetaide}

Taide on yksi kulttuurin peruskäsitteistä. Se koostuu erilaisten elementtien tarkoituksellisen järjestelyn tuloksista sekä prosesseista, joilla pyritään vaikuttamaan tunteisiin ja ajatteluun. Taide on ilmaisun, viestinnän, kannanoton ja mielihyvän tuottamisen väline. Se, onko jokin teos taidetta, riippuu paljolti tarkastelijan omaksumasta taidekäsityksestä.

Kuvataiteet kuuluvat ns. vapaiden taiteiden tai kaunotaiteiden traditioon. Kaunotaiteiksi kutsutaan niitä taiteenlajeja, ${ }^{2}$ joilla pyritään

Taiteen käsitteestä ja jaotteluista esim. Wikipedia, mm. taide, käsitetaide, kirjallisuus, sadut, viihdetaiteilijat.

2 Taiteenlaji on tässä parempi ilmaus kuin taidelaji, koska taidelajilla voidaan tarkoittaa vaikka sellaista urheilulajia, jossa kilpailijoiden tuloksiin vaikuttavat myös taiteelliset seikat. 
puhtaasti esteettiseen lopputulokseen. Sana juontaa antiikin ajalta peräisin olevaan perinteiseen määritelmään, jonka mukaan kaunotaiteita ovat maalaustaide, kuvanveisto, arkkitehtuuri, runous ja musiikki. Kaunotaiteiden vastakohtana ovat soveltavat taiteet. Ne ovat käytännön tarkoituksia palvelevaa taidetta, esimerkiksi taideteollisuuden tuotteita ja mainosgrafiikkaa.

Taiteet voidaan jakaa esittäviin ja ei-esittäviin. Esittävät taiteet, kuten teatteri, elokuva, tanssi ja musiikki, esitetään ajallisessa jatkumossa, ja esitys suunnitellaan siten, että yleisön oletetaan seuraavan esitystä alusta loppuun. Arkkitehtuuri, maalaustaide, grafikka, kuvanveisto, muotoilu ja kirjallisuuden eri lajit eivät perustu aikaan sidottuihin esityksiin, vaan katsoja tai lukija itse valitsee ja päättää katselutilanteen pituuden tai lukemisajankohdan. Tämän takia näitä taidemuotoja kutsutaan ei-esittäviksi taiteiksi. Esittäviä ja ei-esittäviä taiteenaloja voidaan myös yhdistää esimerkiksi performanssissa tai videotaiteessa.

Usein kirjallisuudella viitataan kaunokirjallisiin teoksiin, joiden funktio on esteettisen kokemuksen tuottaminen. Muita kirjallisuuden lajeja ovat tieto-, muistelma- ja viihdekirjallisuus sekä poliittinen, uskonnollinen ja ammattikirjallisuus. Erityisesti tietokirjallisuus pyrkii tiedonvälitykseen.

Runous on vanhin kirjallisuuden laji. Se alkoi suullisena sanataiteena, joka siirtyi runonlaulajan muistista toisen muistiin. Muistia auttoivat runomitat alku- ja loppusoinnuin sekä rytmisin keinoin. Runoille tyypillinen tyylikeino on toisto.

Käsitetaide (konseptualismi) on taidesuuntaus, jota on käytetty 1960-luvun lopulta kuvaamaan sellaisia erilaisia taiteenlajeja, jotka eivät enää saaneet perinteisen taide-esineen muotoa. Käsitetaiteilijat eivät pyri tekemään maalausta tai veistosta ja sitten sovittamaan ajatuksiaan siinä olevaan muotoon. He suuntautuvat perinteisen median rajojen ulkopuolelle ja sen jälkeen työstävät käsitettään tai ajatustaan sopivaan materiaaliin. Käsitetaide voi olla melkein mitä tahansa, mutta 1960-luvun lopulla sen yhteyteen ilmaantui merkittäviä suuntauksia, esimerkiksi performanssitaide ja maataide. Taiteeseen tuli halpoja materiaaleja, kuten peruukkeja, vaatteita ja kaikenlaisia löydettyjä esineitä ja romutavaraa. 


\subsubsection{Taiteilijat, viihde ja viihdetaiteilijat}

Taiteen tekijöitä ovat taiteilijat. Sana on yleisnimitys eri taiteita tekeville. Taiteilija-sanaa voidaan käyttää esimerkiksi musiikin, kirjallisuuden, teatterin, kuvataiteen tai muotoilun harjoittajasta. Kuka tahansa, joka tuntee olevansa luovan taiteellisen työn tekijä jollain kulttuurin taiteenalalla, voi kutsua itseään taiteilijaksi. Kun puhutaan vapaista taiteilijoista, tarkoitetaan yleensä sellaisia taiteilijoita, jotka toimivat itsenäisesti, ilman työnantajaa, mutta se ei estä heitä tekemästä tilaustöitä.

Usein taiteilijalla tarkoitetaan kuitenkin vain taiteen tekemistä ammatikseen harjoittavaa. Ammattitaiteilijan ja taidetta vain harrastuksena tekevän asema poikkeavat toisistaan mm. verotuksessa. Anderssonin ja Gyllströmin teoksessa Kuvataiteilijan verotuksesta (1982) s. 9-10 todetaan seuraavaa:

Rajan vetäminen ammattitaiteilijan ja harrastelijan välille voi tietenkin olla vaikeaa. Käsityksemme mukaan ammattilaisuus on vero-oikeudellisesti laajempi käsite kuin taidepoliittisesti. Joka teknisen taitamattomuutensa takia on ansioituneempien kilpailijoittensa mielestä harrastelijatasolla, on silti katsottava täysin ammattimaisesti toimivaksi kuvataiteilijaksi, jos hän valmistaa taideteoksia myyntiä varten ja tämä tapahtuu siinä laajuudessa, että toiminta on otettava "vakavasti”. Usein juuri nämä taiteellisessa mielessä hieman kyseenalaiset "taiteilijat" menestyvät taloudellisesti paljon paremmin kuin moni ns. tunnustettu taiteilija. Sitä paitsi on muistettava, että ns. hyvä tai huono maku on hyvin suhteellinen käsite, joka vaihtelee aikakaudesta toiseen, eikä tällaisten kysymysten ratkaiseminen kuulu veroviranomaisille.

Verotuksessa kuvataiteilijaa on mielestämme pidettävä ammattilaisena toimintansa laajuudesta ja muista seikoista riippumatta ainakin seuraavissa kolmessa tapauksessa:

1) Jos hän on käynyt maamme korkeimman kuvataidealan oppilaitoksen, Suomen taideakatemian koulun;

2) Jos hän on tai on ollut Taidemaalariliiton, Suomen Kuvanveistäjäliiton tai Suomen Taidegraafikkojen jäsen;

3) Jos hänelle on myönnetty valtion taiteilija-apuraha, valtion taidepalkinto tai taiteilijaeläke.

Yhden yllä mainitun ehdon täyttäminen mielestämme riittää, eikä muuta selvitystä ammattilaisuudesta tällöin tarvitse esittää. 
Verovelvollinen, joka muulla tavalla voi selvittää harjoittavansa kuvataiteilijan ammattia, olisi verotuksessa katsottava ammattilaiseksi riippumatta siitä, onko toiminta voitollista tai tappiollista. Taiteellisen toiminnan taloudellinen tulos on usein jyrkästi epäsuhteessa taiteilijan työpanokseen ja menoihin, joten ammattilaisuutta arvosteltaessa on kiinnitettävä ratkaisevasti enemmän huomiota taiteelliseen toimintaan sinänsä kuin myyntituloihin.

Kuvataiteilija voi periaatteessa toimia vapaana ammattitaiteilijana olematta silti elinkeinoverolain tarkoittama ammatinharjoittaja.

Harrastelija kyllä saattaa kehittyä ammattitaiteilijaksi, mutta päinvastainen kehitys ei sen sijaan liene mahdollinen.

Viihde on yleisnimi kevyelle ajanvietteelle, jonka tarkoitus on tuottaa huvia tai mielihyvää. Esimerkkejä viihteestä ovat mm. sirkus, tanssi, huumori, taikuus, musiikki, elokuvat, pelit, urheilu, teatteri, kirjat, televisio, radio ja lehdet. Useilla viihteen muodoilla on muitakin tarkoituksia kuin viihdyttäminen. Viihdetaiteilijoina pidetään $\mathrm{mm}$. hypnotisoijia, imitaattoreita, klovneja, sirkustaiteilijoita, steppaajia, vatsastapuhujia, drag-artisteja ja showpainijoita.

\subsubsection{Taiteilijoista erikoisina verovelvollisina - vertailua urheilijoihin}

Edellä mainitussa Anderssonin ja Gyllströmin teoksessa taiteilijoita, erityisesti kuvataiteilijoita, ja heidän ongelmallista suhdettaan verotukseen kuvataan seuraavasti (s. 17):

Asiaa hieman kärjistäen voidaan sanoa, että kuvataiteilija yleisen mielipiteen mukaan on vähän hassahtanut henkilö, joka karttaa tavanomaista työtä, elää köyhyydessä, kuolee nuorena ja tulee kuuluisaksi kuolemansa jälkeen. Valitettavasti tässä romanttisessa määritelmässä on aika paljon perää. Elämäntapansa ja työtapojensa suhteen taiteilijat ja varsinkin kuvataiteilijat eroavat huomattavasti ns. tavallisista ihmisistä, ja tällä asialla on vero-oikeudellisessakin mielesstä oleellinen merkitys.

Taiteilija ei yleensä kiinnitä suurta huomiota siihen, tuleeko hän löytämään taideteoksilleen ostajia, vaan hänen toimintansa noudattaa epäkaupallisia periaatteita. Taideteos sinänsä on taiteilijalle tärkeämpi kuin sen taloudellinen tulos. Sen takia sattuukin usein, että taloudellinen tulos ei ole järkevässä suhteessa suoritettuun työpanokseen valmistuskustannuksineen. 
Emme tietenkään väitä, ettei taiteilijoidenkin piiristä löytyisi kylmästi rahallista kannattavuutta ajattelevia yksilöitä, vaikka he ehkä eivät itse haluaisi sitä myöntää. Kaupallisuus on nimittäin taiteesta puheen ollen suorastaan ruma sana. Ja taidefilosofisesti ajatellen taideteoksen todellinen olemus piilee $\mathrm{mm}$. tässä epäkaupallisuudessa ja hyödyttömyydessä.

Olisi erinomaisen tärkeää, että veroviranomaiset ymmärtäisivät tämän taiteelliselle toiminnalle perustavaa laatua olevan erikoispiirteen. Asialla on suuri merkitys varsinkin tulonhankkimiskulujen suhteen. Veroviranomaisten ja taiteilijoiden väliset erimielisyydet tulonhankkimiskulujen vähennyskelpoisuudesta johtuvat usein juuri siitä, että veroviranomaiset arvostelevat asiaa järkevien kannattavuusperiaatteiden mukaisesti, vaikka tällaiset periaatteet ovat taiteelliselle toiminnalle vieraita. Mikäli taiteilijat ryhtyisivät soveltamaan järkeviä kannattavuusperiaatteita toimintaansa, tämä johtaisi kieltämättä useimmissa tapauksissa siihen, että he lopettaisivat toimintansa kannattamattomana ja siirtyisivät ns. porvarilliseen ammattiin.

Taiteellinen toiminta sisältää aina epärationaalisia piirteitä. Psykologiasta yleisesti tunnettu tosiasia on, että taiteellinen lahjakkuus ei edellytä älyllistä lahjakkuutta kuten esim. taloudellista järkevyyttä ja laskutaitoa. Tästä johtuu mm. että asianmukainen kirjanpito tuottaa taiteilijoiden suurelle enemmistölle suuria tai suorastaan ylipääsemättömiä vaikeuksia.

Taiteilijan arvojärjestyksessä tietoisuus hänen taideteoksensa onnistumisesta merkitsee hänelle yleensä eniten. Sen jälkeen hän antaa arvoa kunnialle ja vasta sen jälkeen rahalle. Taiteilijoiden usein täysin järjettömiltä vaikuttavat sijoitukset ja suuret henkilökohtaiset uhraukset taiteensa puolesta on ymmärrettävä tätä taustaa vasten. On myös ymmärrettävä, että kaikki nämä henkilökohtaiset "erikoisuudet" ovat erottamattomasti sidottuina niihin ominaisuuksiin, jotka tekevät ihmisestä taiteilijan. Verotus, joka ei ota huomioon näitä taiteelliselle toiminnalle oleellisia epäkaupallisia piirteitä, ei ole oikeudenmukainen vaan voi kohdella taiteilijoita muita veronmaksajia ankarammin. Verotuksen asiana ei ole säädellä ihmisten käyttäytymistä, vaan sen tulee määrittää veronsaajien osuus siitä todellisesta taloudellisesta tuloksesta, johon verovelvollinen on toiminnallaan päässyt.

Taidetta verrataan usein urheiluun. Urheilua on luonnehdittu kirjassani Urheilu ja verotus (1984) s. 1 ss. seuraavasti:

Urheilussa on elämänilmiönä vaihteleva määrä piirteitä leikistä ja työstä. Urheilun omaleimaisuutta on pyritty varjelemaan mm. amatöörisäännöillä, joiden tarkoituksena on ollut urheilun säilyttäminen yksilön omaehtoisena, työlle vastakkaisena harrastuksena. Huippu-urheilijat eivät kuitenkaan aina kovinkaan paljon poikkea tässä toiminnassa normaalia 
työtä tekevistä, vaikka heitä pidettäisiinkin urheilusääntöjen mukaan amatööreinä. Amatöörisäännöt ovat melkoisesti väljentyneet ja niiden merkitys muutoinkin vähentynyt. Urheilu on ammatillistunut.

Tapahtunutta kehitystä voidaan kutsua myös ammattilaistumiseksi ja ammattimaistumiseksi. Termi "ammatillistua" lienee näitä parempi, koska se on hieman lyhyempi ja myös helpommin pidettävissä erillään käsitteistä "ammattilaisurheilu" ja "ammattiurheilu". Ammattilaisurheilun eli ammattiurheilun käsite ei ole vakiintunut, mutta usein sillä tarkoitetaan urheilusääntöjen mukaan ammattiurheiluna pidettävää urheilua, jota voidaan kutsua myös varsinaiseksi ammattiurheiluksi. Tämä käsite on hankala mm. sen vuoksi, ettei kaikissa urheilumuodoissa ole amatöörisääntöjä lainkaan.

Urheilun ammatillistumisesta puhuttaessa ongelmaa tarkastellaan lähinnä urheilijoiden ajankäyttöä ja tuloja silmällä pitäen. Urheilun ammatillistumiseen liittyy läheisesti kaupallistuminen. Mikäli urheilun rahoitus on keskeisesti esimerkiksi pääsylipputulojen tai mainostulojen varassa, joutuvat urheilijat helposti kiinteään riippuvuussuhteeseen liiketaloudellisten periaatteiden mukaan menettelevän yritystoiminnan kanssa. Urheilijoista tulee eräänlaisia kauppatavaroita, joita myydään, ostetaan ja vuokrataan.

Vaikka ammatillistuminen ja kaupallistuminen liittyvät läheisesti toisiinsa, ne ovat kuitenkin ainakin periaatteessa pidettävissä toisistaan erillään. On mahdollista ajatella järjestelmää, jossa urheilija päätyökseenkin urheilee ja saa tästä kunnollisen taloudellisen korvauksen ilman, että häntä käytetään kaupallisesti hyväksi. Toisaalta on mahdollinen myös sellainen järjestelmä, jossa urheilija joutuu kaupallisen hyväksikäytön kohteeksi ilman, että hän saa tästä taloudellista hyötyä.

Suomessa aatteelliselta pohjalta syntyneiden urheiluorganisaatioiden asema on ollut varsin vahva. Ammatillistunut ja kaupallistunutkin urheilu on yleensä säilynyt ainakin kohtalaisesti niiden valvonnassa. Ammatillistumiseen ja erityisesti kaupallistumiseen liittyvä urheilun arvorakenteen järkkyminen voi kuitenkin merkitä urheilun muuttumista joksikin muuksi ilmiöksi näennäisestä samankaltaisuudestaan huolimatta; se voi muuttua esimerkiksi viihdeteollisuudeksi tai mainostoiminnaksi, jolla ei ole sosiaalipedagogista arvoa.

Urheilun merkitys vaihtelee eri aikoina ja erilaisissa yhteiskunnissa. Yhteiskunnan voidaan odottaa yleensä ohjaavan myös urheilua palvelemaan yleisiä tavoitteitaan. Varsin keskeisellä sijalla urheilun yhteiskunnallisessa ohjauksessa on toiminnan organisaatioita koskevan säännöstön lisäksi julkinen rahoitus.

Julkista rahoitusta voi tapahtua esimerkiksi urheilupaikkojen yhteiskunnallisen omistuksen muodossa. Sitä voi tapahtua myös siten, että tietynlaiset varainhankintakeinot annetaan tietynlaisten yhteisöjen yksinoikeudeksi. Suorempaa julkista rahoitusta toteutetaan mm. julkisilla 
avustuksilla. Julkiseen rahoitukseen liittyy myös verotuksella tapahtuva puuttuminen yksityiseen toimintaan.

Jäljempänä kirjan III osassa käsitellään useita taiteelle ja urheilulle yhteisiä verokysymyksiä.

\subsection{Taiteen sääntely ja taiteilijan oikeudet}

\subsubsection{Perustuslaki ja taidelainsäädäntö ${ }^{3}$}

Perustuslain 16.3 \$:n mukaan tieteen ja taiteen vapaus on turvattu. Taiteen vapauden ydin muodostuu taiteen harjoittamisen periaatteellisesta rajoittamattomuudesta, johon kuuluu myös oikeus itse valita aiheensa, menetelmänsä ja ilmaisemisen tapansa. Vapaus koskee sekä ammatillista taiteen harjoittamista että harrastuspohjaista toimintaa. ${ }^{4}$

Toinen tärkeä perusoikeus on sananvapaus, ja se koskee taiteilijoitakin. Perustuslain $12 \$$ :n mukaan sananvapauteen kuuluu oikeus ilmaista, julkistaa ja vastaanottaa tietoja, mielipiteitä ja muita viestejä kenenkään ennakolta estämättä. Tarkempia säännöksiä sananvapauden käyttämisestä annetaan lailla. Lailla voidaan myös säätää kuvaohjelmia koskevia lasten suojelemiseksi välttämättömiä rajoituksia.

Perustuslain 20 \$:n mukaan vastuu luonnosta ja sen monimuotoisuudesta, ympäristöstä ja kulttuuriperinnöstä kuuluu kaikille, siis myös taiteilijoille. Jokaisella on perustuslain $18 \$$ :n mukaan oikeus hankkia toimeentulonsa valitsemallaan työllä, ammatilla tai elinkeinolla. Elinkeinovapaus, kuten perustuslain 15 \$:ssä turvattu omaisuuden suojakin, koskee myös taiteilijoita.

Suomessa on runsaasti erityistä taidelainsäädäntöä. Verotuksenkin kannalta kiinnostavia ovat esimerkiksi seuraavat lait: laki taiteilijaprofessorin viroista ja valtion taiteilija-apurahoista (734/1969), laki eräistä kirjailijoille ja kääntäjille suoritettavista apurahoista ja avustuksista (236/1961), laki eräistä kuvataiteen tekijöille suoritettavista

Ks. tarkemmin Rautiainen Taiteen vapaus perusoikeutena (2007).

Arajärvi Tieteen termipankki, taiteen vapaus (perusoikeutena). 
apurahoista (115/1997) sekä tekijänoikeuslaki (404/1961). Näistä viimeksi mainittua on syytä tarkastella seuraavaksi hieman laajemmin.

\subsubsection{Taloudelliset ja moraaliset tekijänoikeudet tekijänoikeuslain mukaan}

Tekijänoikeuksien merkitys kasvoi 1800-luvulla mm. sanomalehdistön ja kirjateollisuuden laajentuessa. Tekijänoikeuksista on 1880-luvulta lähtien tehty myös kansainvälisiä sopimuksia. Nykyisin tärkeitä ovat mm. tekijänoikeuksia sääntelevät EU-direktiivit.

Suomessa tekijänoikeuksia säännellään tekijänoikeuslaissa (404/1961). Sillä, joka on luonut kirjallisen tai taiteellisen teoksen, on tekijänoikeus teokseen, olkoonpa se kaunokirjallinen tahi selittävä kirjallinen tai suullinen esitys, sävellys- tai näyttämöteos, elokuvateos, valokuvateos tai muu kuvataiteen teos, rakennustaiteen, taidekäsityön tai taideteollisuuden tuote taikka ilmetköönpä se muulla tavalla (1 $\$)$. Kirjallisena teoksena pidetään myös karttaa sekä muuta selittävää piirustusta tai graafista taikka plastillisesti muotoiltua teosta sekä tietokoneohjelmaa.

Tekijänoikeus tuottaa laissa säädetyin rajoituksin yksinomaisen oikeuden määrätä teoksesta valmistamalla siitä kappaleita ja saattamalla se yleisön saataviin, muuttamattomana tai muutettuna, käännöksenä tai muunnelmana, toisessa kirjallisuus- tai taidelajissa taikka toista tekotapaa käyttäen $(2 \$)$.

Tekijänä pidetään, jollei näytetä toisin olevan, sitä, jonka nimi taikka yleisesti tunnettu salanimi tai nimimerkki yleiseen tapaan pannaan teoksen kappaleeseen tai ilmaistaan saatettaessa teos yleisön saataviin $(7 \$)$.

Julkistetusta teoksesta on lupa hyvän tavan mukaisesti ottaa lainauksia tarkoituksen edellyttämässä laajuudessa (22 \$). Julkistetuista taideteoksista saa ottaa tekstiin liittyviä kuvia arvostelevaan tai tieteelliseen esitykseen $(25 \$)$.

Teoksen tekijä on luonnollinen henkilö eli ihminen. Tekijänoikeus voidaan luovuttaa kokonaan tai osittain $(27 \$)$. Luovutuksen saajana voi olla myös yhtiö, yhdistys tai säätiö. Tekijän kuoltua sovelletaan tekijänoikeuteen avio-oikeutta, perintöä ja testamenttia koskevia sääntöjä (41 \$). Tekijä saa testamentilla, myös eloon jäänyttä puolisoa 
sekä rintaperillistä, ottolasta ja tämän jälkeläistä sitovasti, antaa määräyksiä tämän oikeuden käyttämisestä tai valtuuttaa toisen antamaan sellaisia määräyksiä.

Tekijänoikeus on yleensä voimassa, kunnes 70 vuotta on kulunut tekijän kuolinvuodesta $(43 \$)$. Oikeus valokuvaan on voimassa, kunnes 50 vuotta on kulunut sen vuoden päättymisestä, jona kuva valmistettiin ( 49 a $\$$ ).

Edellä on ollut puhetta lähinnä taloudellisista tekijänoikeuksista. Tekijänoikeuslain 3 \:ssä säädetään moraalisista oikeuksista. Kun teoksesta valmistetaan kappale taikka kun teos kokonaan tai osittain saatetaan yleisön saataviin, on tekijä ilmoitettava sillä tavoin kuin hyvä tapa vaatii $(3 \$)$. Teosta ei saa muuttaa tekijän kirjallista tai taiteellista arvoa tahi omalaatuisuutta loukkaavalla tavalla. Moraaliset oikeudet eivät ole verotuksessa yhtä merkityksellisiä kuin taloudelliset, mutta eivät nekään aivan merkityksettömiä ole ainakaan vahingonkorvausten osalta.

\subsection{Vero ja verovelkasuhteen osapuolet}

\subsubsection{Veron käsite}

Nykyisin vakiintuneen määritelmän mukaan vero on rahasuoritus, joka ei ole korvaus tai vastike julkisen vallan maksuvelvolliselle antamista eduista tai palveluksista ja jolle on ominaista julkisten menojen rahoittaminen. Maksulla puolestaan tarkoitetaan korvausta tai vastiketta viranomaisten virkatoimista, palveluksista tai muusta toiminnasta. Sellainen valtion perimä "maksu", joka selvästi ylittää kustannukset, ei valtiosääntöoikeudellisesti ole maksu vaan vero.

\subsubsection{Verosubjektit, vero-objektit ja verolajit}

Verotusoikeuden omaavia julkisyhteisöjä, joita ovat ennen kaikkea valtio ja kunnat, kutsutaan veronsaajiksi. Niitä, joiden velvollisuutena on veron maksaminen, sanotaan verovelvollisiksi. Joskus veronsaajia nimitetään myös aktiivisiksi verosubjekteiksi ja verovelvollisia 
passiivisiksi verosubjekteiksi, mutta tällainen nimittely tuskin selventää asiaa, pikemminkin päinvastoin.

Verovelvollisuus liittyy johonkin tiettyyn seikkaan, jota voidaan kutsua vero-objektiksi. Vero-objektina voi olla esimerkiksi tulo, perintö tai kuluttaminen. Tärkeimpiä verolajeja Suomessa ovat nykyisin tulovero, perintö- ja lahjavero, arvonlisävero, monet valmisteverot, autovero, ajoneuvovero ja varainsiirtovero sekä kunnallinen kiinteistövero.

\subsubsection{Verotuksen toimittamisen ja veronkannon kehitys}

\subsubsection{Välitön verotus}

Keskiajalla Ruotsin kruunu sai pääosan tuloistaan erilaisista veroista, joista vastasivat kaksi alempaa säätyä eli porvaristo ja talonpojat. Maallinen rälssi (aatelisto) ja kirkollinen rälssi (papisto), olivat kumpikin veroista vapautettuja.

Verotulot kulutettiin hallintokuluihin, linnojen ja kartanoiden ylläpitoon sekä sotaväen palkkoihin. Käsitettä "kruunun sosiaalipolitiikka" ei tunnettu, eikä kruunu jakanut tulonsiirtoja rahvaalle, vaan väestön huollosta, köyhäinhoidosta ja kyläyhteisön muista tehtävistä huolehtivat kirkko ja koko pitäjäyhteisö. Kruunu alisti myös keskiajan mahdin, kirkon, taloudellisen vallan ottamalla haltuunsa ensimmäiseksi piispanverot. Vähitellen yhä useampi kirkollinen vero liukui kruunun kontrolliin. Kustaa Vaasan hallitsijakaudella 1500-luvulla alettiin pitää maakirjoja ja veronkantoluetteloita säännöllisesti kaikissa Suomen maakunnissa. Sekä talonpojille että verot kerääville voudeille oli tärkeää, että verotus jatkui pääsääntöisesti vanhaan malliin - luku- ja kirjoitustaidottomien talonpoikaisten veronkerääjien oli helpompi kerätä vuotuiset ja säännölliset verot samaan tapaan kuin aina ennenkin.

Kuninkaan vallan kasvu perustui ratkaisevasti valtiontalouden tehostamiseen. Tärkein keskushallinnon instituutio oli verokamari, joka jakautui tilikamariin ja laskukamariin ja toimi suoraan kuninkaan käskyvallan ja kontrollin alaisena. Kustaa Vaasan ansiona on pidetty sitä, että kruunusta tuli myös kirkon ja paikallishallinnon verojen vartija. 
Kruunun paikallishallinto koostui voutikunnista, joiden johdossa toimivat voudit. He kontrolloivat verojen maksamista. Luotettava vouti oli kuninkaalle kultaakin kalliimpi, mutta talonpoika näki asian toisin. Valtiovalta ruumiillistui talonpojan silmissä usein juuri voutiin. Voutia pidettiin ahneena ja julmana, ja hän sai tuntea rahvaan vihat niskassaan. Kustaa Vaasa jätti jälkeensä hyvin hoidetun maan talouden, mutta hänen poikiensa aikana säästöt hupenivat ja valtakunta oli lähes kaiken aikaa sodassa.

Niin sanotun suuren reduktion jälkeen 1600-luvun lopulla Ruotsin kruunu ulkoisti veronkannon monilla valtiolle palautuneilla alueilla. Simon Affleck eli Simo Hurtta oli veronvuokraaja (arrendaattori), jonka kansa muistaa säälimättömänä ja julmana. Häneen palataan jäljempänä taidekirjallisuutta koskevassa osassa.

Vuosi 1865 oli merkittävä myös Suomen vero-oikeuden historiassa. Tuolloin annettiin keisarin julistus siitä suostuntaverosta, jonka Suomenmaan Säädyt olivat ottaneet maksaakseen vuosina 1865-1867. Julistuksella otettiin Suomessa ensi kertaa käyttöön yleinen tuloverotus.

Jokaisen tuli "suostuntawerokomitealle ilmoittaa, kuinka suureksi hän arvaa puhtaan tulonsa wiimeksi kuluneelta wuodelta". Ilmoittamisvelvollisuuden merkitys jäi todellisuudessa vähäiseksi, koska velvollisuutta ei ollut sanktioitu. Tulojen todellinen märää jäikin verovelvollisen moraalin varaan, joten verotus muistutti nykyistä arvioverotusta. Ensimmäinen tuloverotus epäonnistui, mihin vaikutti osaltaan asennoituminen tulojen ilmoittamiseen: liberalistinen veropolitiikka suhtautui varsin torjuvasti ilmoittamisvelvollisuuteen. Epäonnistuminen johtui myös talouden rakenteesta; verotus nettotulojen perusteella edellyttää markkinatalouden, teollisuuden ja rahatalouden kehittyneisyyttä.

Myöhemmän kehityksen kannalta suuri tapahtuma oli ennakkoperintäjärjestelmän synty. Suomen ensimmäinen ennakkoperintälaki säädettiin vuonna 1943 , ja sitä perusteltiin mm. sodasta johtuvalla verojen perinnän kehittämistarpeella (HE 59/1943).

Ennen 1960-lukua verovelvollisten oli laadittava erilliset veroilmoitukset valtionverotusta varten ja kunnallisverotusta varten. Siihen aikaan valtiolla ja kunnilla oli omat erilliset paikalliset verotuselimensä. 
Verotus oli pitkään käsityötä. Verohallinnossa 1940-luvun alussa pidetyssä esitelmässä esimerkiksi todettiin:

" [- - ] olisi huomiota kiinnitettävä siihen, että ainakin kaikki suuremmat verotuslautakunnat saisivat käytettäväkseen lasku- ja kirjoituskoneen. [- - ] Nykyhetkellä on ehkä vaikea tätä toivomusta toteuttaa, joten verotuslautakuntien täytynee toistaiseksi tulla toimeen vuokraamillaan lasku- ja kirjoituskoneilla, sikäli kun he onnistuvat niitä vuokraamaan.”

Valtiovarainministeriön kirjeen 17.1.1927 mukaan "Verotuskonsulenttien tehtävänä on antaa tulo- ja omaisuusverotusta varten verotuslautakunnille sekä perintöverolautakunnille ohjausta ja neuvoja sekä erityisesti toimia verovelvollisten kirjanpitoa koskevissa asioissa [- - ] asiantuntijana”. Sittemmin verotuskonsulentteja alettiin kutsua verotusneuvojiksi. Veroviranomaisia opastavien verotuskonsulenttien rooli näkyy olleen hyvin toisenlainen kuin nykyajan verokonsulteilla, jotka maksua vastaan neuvovat verovelvollisia.

Vuoden 1943 alusta lakkautettiin lääninhallituksissa olevat verotusneuvojain toimet ja verotusneuvojain tehtävät siirtyivät verotarkastajien tehtäväksi. Verotarkastajilla oli verotusviranomaisten päätöksiin nähden samanlainen valitusoikeus kuin valtion etua valvovalla lautakunnan jäsenellä.

Vuoden 1943 tulo- ja omaisuusverolain mukaan lääninhallitus asetti verotuslautakuntaan kolmeksi vuodeksi puheenjohtajan sekä puolet jäsenistä, joista yksi määrättiin valtion asiamieheksi. Valtion asiamies oli siis verotuslautakunnan äänivaltainen jäsen ja niin ollen oikeutettu ottamaan osaa sekä asian käsittelyyn että päätösten tekemiseen.

Verotoimistoissa verovirkailijat tallensivat palautetut veroilmoitukset, ja puuttuvia tietoja tiedusteltiin erikseen. Ilmoitukset aakkostettiin, mapitettiin ja sitten säilytettiin verotoimistossa. Kaikkien verovelvollisten ilmoitukset ja kaikki ilmoitetut asiat tutkittiin. Tulojen maksajilta alettiin saada 1970-luvulla enemmän tietoja, joita käytettiin aluksi tarkkailutietoina siten, että verovelvollisen ilmoittamia tietoja verrattiin tietojen luovuttajilta saatuihin tietoihin. Ns. suora tiedonsaanti tuli verotuksen perustaksi 1980-luvulla, kun voitiin luottaa saatujen tietojen oikeellisuuteen. Esimerkiksi eläkkeet vapautettiin 
verovelvollisen ilmoittamisvelvollisuuden piiristä, ja Verohallinto pystyi esitäyttämään ne veroilmoituksiin.

Vuoden 1960 alussa voimaan tulleen verotuslain mukaan veronsaajien etua valvoivat erityiset asiamiehet, jotka olivat verovelvollisen vastapuolia. Asiamiesjärjestelmän avulla luotiin verotukseen kaksiasianosaissuhde turvaamaan ratkaisutoiminnan tosiasiallista puolueettomuutta, jolloin veronsaajien edun erityinen valvominen ei ollut verotuksen toimittajan tehtävänä. Verolautakunta oli asianosaisiin nähden näiden yläpuolella oleva puolueeton elin: sen tehtävänä oli toimittaa verotus asianosaisten esittämien tosiseikkojen perusteella. Joka kunnassa oli verolautakunta, johon valtiovarainministeriö määräsi valtionasiamiehen. Kunnallishallitus puolestaan määräsi lautakuntaan kunnanasiamiehen. Valtionasiamiehenä ja kunnanasiamiehenä saattoi olla samakin henkilö. Joka läänissä oli lääninverolautakunta, johon valtiovarainministeriö kuultuaan kunnallisia keskusjärjestöjä määräsi verotusasiamiehiä. Verotusasiamiehet valvoivat valtion, kuntien, seurakuntien ja Kansaneläkelaitoksen oikeuksia. Lääninoikeudessa näiden tahojen oikeutta valvoi tarkastusasiamies, jonka valtiovarainministeriö määräsi kuultuaan kunnallisia keskusjärjestöjä.

Vuodesta 1996 alkaen siirryttiin vaiheittain päätoimisten veroasiamiesten järjestelmään, jossa Verohallinto huolehti oikeudenvalvonnan järjestämisestä. Erilaiset veronsaajien asiamiesten nimikkeet korvattiin nimikkeellä veroasiamies. Veronsaajien oikeudenvalvonta säädettiin vuodesta 2008 Verohallinnon tehtäväksi. Verohallinto sekä toimittaa verotuksen että valvoo veronsaajan oikeutta verotuksessa, mutta nämä kaksi tehtävää pidetään erillään toisistaan. Oikeudenvalvontatehtävää hoitaa erityinen Veronsaajien oikeudenvalvontayksikkö (VOVA).

Vuodesta 2005 alkaen verovelvollisen ei ole tarvinnut palauttaa veroilmoitustaan, jos hänellä ei ole ollut lisättävää tai korjattavaa siinä oleviin esitäytettyihin tietoihin. Kaikkien verovelvollisten (joita nykyisin kutsutaan asiakkaiksi) verotustiedot käsitellään koneellisesti. Lisäksi veroviranomainen tutkii valikoivan verovalvonnan perusteella osan aineistosta tarkemmin tapauskohtaisessa käsittelyssä. Koneellisessa käsittelyssä tutkitaan mm. tietojen loogisuutta ja tietojen ilmoittamista tai ilmoittamatta jättämistä, ja tietoihin sovelletaan Verohallinnon laatimia salassa pidettäviä ja valtakunnallisesti yhdenmukaisia valikointitietoja. Mikäli asia ei valikoidu tapauskohtaiseen 
käsittelyyn, verotuspäätös syntyy koneellisessa käsittelyssä. Verovuodesta 2013 alkaen on otettu käyttöön valtakunnalliset työjonot. $\mathrm{Ne}$ merkitsevät käytännössä sitä, että verotusta ei enää toimiteta paikallisessa verotoimistossa, vaan virkailijat voivat ottaa työjonosta asiakkaan käsittelyyn missä tahansa verotoimistossa.

Ennakkoperintää on kehitetty viime aikoina voimakkaasti niin, että se yhä paremmin vastaa lopullista verotusta.

Ennakkoperintälain (1118/1996) 2 \$:n mukaan ennakkoperintä toimitetaan ennakonpidätyksenä tai ennakonkantona. Lain 3 \$:n mukaan ennakonpidätyksen määrän on vastattava mahdollisimman tarkoin verovelvollisen ennakonpidätyksen alaisesta tulosta verovuoden veroasteikkolain ja muiden verovuoden veroperusteiden mukaan maksettavaa verojen ja maksujen yhteismäärä. Ennakonkannossa veroa määrätään verovelvollisen maksettavaksi määrä, joka vastaa mahdollisimman tarkoin verovelvollisen tuloista verovuonna sovellettavien veroperusteiden mukaan maksettavaa verojen ja maksujen yhteismärää, vähennettynä ennakonpidätyksenä kertyväksi arvioidulla määrällä.

Verohallinto voi verovelvollista kuulematta merkitä ennakonpidätyksen määrän prosentteina suorituksen saajan verokorttiin tai siirtää tiedon suoraan ennakonpidätyksen toimittamiseen velvolliselle (10 \$). Ennakonpidätys toimitetaan siten, että suorituksen maksaja vähentää ennakonpidätysprosentin mukaan lasketun määrän rahana maksettavasta määrästä suorituksen yhteydessä tai merkitessään sitä tilille asianomaisen hyväksi $(11 \S)$.

Palkalla tarkoitetaan EL 13 \$:n mukaan:

1) kaikenlaatuista palkkaa, palkkiota, etuutta ja korvausta, joka saadaan työ- tai virkasuhteessa;

2) kokouspalkkiota, henkilökohtaista luento- ja esitelmäpalkkiota, hallintoelimen jäsenyydestä saatua palkkiota, toimitusjohtajan palkkiota, avoimen yhtiön ja kommandiittiyhtiön yhtiömiehen nostamaa palkkaa sekä luottamustoimesta saatua korvausta.

Harkittaessa sitä, onko korvaus saatu työsuhteessa, ei oteta huomioon sellaisia työn teettäjän ja työn suorittajan välisen sopimussuhteen ulkopuolisia seikkoja, joita työn teettäjä ei voi havaita. Tällaisia seikkoja voivat olla esimerkiksi työn suorittajan toimeksiantajien lukumäärä ja muun toiminnan laajuus.

Työnantaja voi korvata palkansaajan vaatimuksesta hänelle kertyvät työstä välittömästi johtuvat kustannukset tai vähentää kustannusosuuden ennen ennakonpidätyksen toimittamista (EPL 15 \$). Tällaisina 
kustannuksina voidaan ennakonpidätystä toimitettaessa ottaa huomioon työvälineistä sekä valmistus- ja tarveaineista aiheutuneet menot, matka- ja edustusmenot sekä muut palkansaajalle työn suorittamisesta välittömästi aiheutuneet menot.

Ennakonkannon toimittamisesta säädetään EPL 23 \$:ssä. Elinkeinotoiminnan ja muun tulonhankkimistoiminnan tuottaman tulon perusteella määrättävän veron suoritukseksi toimitetaan yleensä ennakonkanto. Verovelvollinen maksaa ennakonkannossa määrätyn veron Verohallinnon päätöksen mukaisesti yhteen tai useampaan erään jaettuna, viimeistään valtiovarainministeriön asetuksessa säädettynä eräpäivänä.

Suorituksen maksajan on EPL 25 \$:n mukaan toimitettava ennakonpidätys, jos saajaa ei ole merkitty ennakkoperintärekisteriin:

1) työstä, tehtävästä tai palveluksesta muuna kuin palkkana maksettavasta korvauksesta (työkorvaus);

2) tekijänoikeuden, valokuvaan perustuvan oikeuden ja teollisoikeuden, kuten patentin tai tavaramerkin käyttämisestä, käyttöoikeudesta tai käyttöoikeuden myynnistä suoritettavasta korvauksesta taikka teollisia, kaupallisia ja tieteellisiä kokemuksia koskevista tiedoista suoritettavasta korvauksesta (käyttökorvaus).

Ennakkoperintärekisterin käyttötarkoituksena on parantaa suorituksen maksajan oikeusturvaa ja tehostaa verojen kertymistä.

\subsubsection{Tullit ja muu kulutusverotus}

Tullimaksujen kanto Suomessa liittyy yhteiseen historiaamme Ruotsin kanssa. Samalla tullimaksut ovat olleet olennaisesti yhteydessä kaupunkien syntyyn ja kaupan kasvuun.

Kun Ruotsi oli Suomen sodassa (1808-1809) menettänyt Suomen alueen Venäjälle, keisari Aleksanteri I hyväksyi vuonna 1812 ohjesäännön Suomen suuriruhtinaskunnan tullihallinnolle. Suomeen perustettiin oma tulliasioista vastaava keskusvirasto, jonka nimi oli aluksi päätullijohtokunta ja vuodesta 1885 alkaen Tullihallitus. Se vastasi mm. tullitulojen kannosta ja valvoi tullikamareiden toimintaa. Tullilaitoksen voidaan sanoa kuuluneen 1800-luvulla itsenäisyytemme tärkeisiin pohjustajiin. Tullilaitosta kehitettiin ensi sijassa maamme omien tarpeiden mukaisesti, ja niin tullissa ei tarvittukaan suuria muutoksia, kun Suomi vuoden 1917 lopulla itsenäistyi. Yhtä joustavasti tullilaitoksemme mukautui 1990-luvun puolivälissä osaksi EU:n tullijärjestelmää, jossa tullitulot kerätään EU:lle. 
Tullien osuus Suomen valtion verotuloista oli 1830-luvun lopulla vajaa viidennes ja 1850-luvulla yli $40 \%$. 1900-luvun alussa tullien osuus valtionverotuloista kohosi $70 \%$ :iin. Tullitulot olivat 1930-luvulle asti Suomen valtiontalouden selkäranka. Kun tullit alenivat, niiden fiskaalinen merkitys vähentyi olennaisesti. Silti tullilaitos säilyi tärkeänä veronkantolaitoksena.

Valmisteverotus on Suomessa kuulunut pitkään tullilaitokselle. Vuosina 1937-1949 valmisteverotuksesta huolehti leima- ja valmisteverokonttori, joka muodostettiin yhdistämällä Suomen leimakonttori ja tullilaitoksen yhteydessä toiminut aksiisikonttori. Vuonna 1949 leima- ja valmisteverokonttorin leimatoimiston tehtävät siirrettiin Suomen Pankille ja muu osa konttorista muutettiin valtiovarainministeriön alaiseksi valmisteverokonttoriksi. Valmisteverokonttori lakkautettiin vuoden 1970 alussa, ja sen tehtävät siirrettiin Tullihallitukselle.

Autoverotuksen toimittava viranomainen maahantuotujen ajoneuvojen osalta oli pitkään Tulli. Suomessa valmistettujen ajoneuvojen osalta verotuksen toimittava viranomainen sen sijaan vaihteli. Aikoinaan nämä verotustehtävät kuuluivat liikevaihtoverotoimistolle, mutta liikevaihtoverotoimistojen lakkauttamisen jälkeen kotimaassa valmistettujen ajoneuvojen verotuksen toimitti lääninverovirasto. Vuoden 1995 alussa myös kotimaassa valmistettujen ajoneuvojen autoverotus siirrettiin Tullin tehtäväksi.

Ajoneuvoverotuksen hallinnointi kuului 1920-luvulta aina 1960-luvulle asti lääninhallituksille, joissa toimitettiin myös autojen ja moottoripyörien rekisteröinti. Ajoneuvojen rekisteröinti lääninhallituksissa päättyi vuoden 1965 lopussa, ja se jatkui 1.1.1966 valtakunnallisessa Autorekisterikeskuksessa. Autorekisterikeskuksen tilalle tuli vuonna 1996 Ajoneuvohallintokeskus, jonka taas vuoden 2010 alussa korvasi Trafi.

Liikevaihtoverotusta varten perustettiin liikevaihtoverokonttori, joka aloitti toimintansa 1.2.1941. Paikallisviranomaisina toimivat lääneissä ja Helsingin kaupungissa liikevaihtoverotoimistot. Liikevaihtoverokonttorin tehtävät siirrettiin vuonna 1970 silloin perustetulle Verohallitukselle. Liikevaihtoverotoimistot puolestaan lakkautettiin vuonna 1989, ja niiden tehtävät siirtyivät lääninverovirastoille. Maahantuonnin arvonlisäverotus kuului pitkään Tullille. 
Nykyisin myös valmisteverotus, autoverotus ja maahantuonnin arvonlisäverotus ovat Verohallinnon hoidettavina. Pyrkimyksenä on ollut parantaa palvelua ja ohjausta sekä tehostaa verovalvontaa, kun toiminnassa mahdollistuu veronmaksajien kokonaisvaltainen tarkastelu verolajikohtaisen tarkastelun sijaan. Tavoitteena on myös välttää päällekkäisten tietojärjestelmien rakentaminen ja ylläpito eri organisaatioissa sekä saavuttaa kustannussäästöjä.

\subsubsection{Yhteenvetoa}

Verotusmenettely on kehittynyt viime aikoina voimakkaasti. Voidaan sanoa, että luottamusmiesten ja virkamiesten toimittamasta verotuksesta on siirrytty tietokoneelliseen verotukseen ja hyvin lähelle sellaista itseverotusta, jossa verovelvolliset suurelta osin itse toimittavat oman verotuksensa.

\subsubsection{Verosanastoa eri kielissä}

\subsubsection{Vero}

Maamme vanhimman verohistorian jälkiä etsittäessä huomio kiinnittyy joihinkin suomalaisiin nimityksiin. Yksi sellainen nimitys on itse sana vero. Saamen kielen värro on merkinnyt sekä uhria että veroa. ${ }^{5}$ Muun muassa veroja välttääkseen saamelaiset siirtyivät yhä pohjoisemmaksi. Lapissa valtioiden rajat olivat 1700-luvun puoliväliin asti niin epämääräiset, että laajoja alueita verotti kaksi tai kolmekin valtiota yhtä aikaa. Tuolloin ei ollut vielä solmittu esimerkiksi OECD:n mallin mukaisia verosopimuksia useampikertaisen verotuksen välttämiseksi.

Vero-sana on ilmeisesti suomessakin alkuaan merkinnyt uhria, mutta vero on sittemmin saanut maallisen merkityksen. Tämä tukee sitä yleistä katsomusta, että yksi julkisoikeudellisen verotuksen juuri johtaa muinaiseen uhriyhteiskuntaan.

Ruotsiksi vero on skatt. Sama sana merkitsee myös aarretta. Skatta on verbi, jolla on seuraavat merkitykset: 1) maksaa veroa, 2) verottaa,

5 Veron etymologiasta esim. Voionmaa Suomalaisia keskiajan tutkimuksia (1912) s. 41 ss. 
ryöstää ja 3) arvioida. Skatte puolestaan tarkoittaa veromaata. Myös norjassa vero on skatt, tanskassa se on skat. ${ }^{6}$

Englannin tax-sanan pohjana on latinan arvioimista tarkoittava verbi taxare. Varsinkin tuontiveroista käytetään termiä duty, joka tarkoittaa myös velvollisuutta. Amerikansuomessa eli fingelskassa täksi on tarkoittanut sekä veroa että taksia. ${ }^{7}$

Saksan kielessä veroa tarkoittava Steuer tulee muinaisyläsaksan sanasta stiura, joka tarkoitti tukea ja apua. Veroa tarkoittava Steuersana on die-sukuinen, ja se voi tarkoittaa myös vapaaehtoista avustusta ja lahjaa. Neutrisukuinen Steuer puolestaan tarkoittaa ruoria ja ohjauspyörää. Ranskassa vero on impót, espanjassa impuesto ja italiassa imposta. Näiden sanojen etymologisena pohjana on latinan verbi imponere, joka tarkoittaa mm. määrätä jonkun rasitukseksi.

Veroa tarkoittava termi virossa on maks. Myös suomessa veroista käytetään joskus termiä maksu ja ruotsissa avgift, vaikka valtiosääntöoikeudellisesti veron ja maksun ero on suuri. Viron kielessä sana taks tarkoittaa taksaa ja mäyräkoiraa ${ }^{8}$, sana takso puolestaan taksia.

Venäjäksi vero on nalog tai sbor. Tässä kirjassa itäeurooppalaisen aineiston osuus on mm. kielirajoitteitten vuoksi vähäinen. Puolaksi vero on podatek, mutta esimerkiksi Kayahin laulussa (2017) "Podatek Od Miłości" (rakkauden vero) käsitellään inhimillisiä rakkausongelmia eikä julkisyhteisölle maksettavaa veroa.

\subsubsection{Muuta verosanastoa}

Taiteen piirissä ei juuri käytetä virallisluonteisia ilmauksia verolainsäätäjä, veronsaaja, verohallinto, veroviranomainen, verotuomari ja verovelvollinen. Siksi ne eivät ole hyviä hakusanoja etsittäessä aineistoa kirjan alkuosaan eli siihen, miten verot ilmenevät taiteessa. Viralliset termit sen sijaan ovat käyttökelpoisia kirjan loppupuolella tutkittaessa taiteiden verotusta.

Erikielisten veroa tarkoittavien sanojen lisäksi tämän tutkimuksen alkupuolen osalta kiinnostavia verotukseen liittyviä suomen sanoja ovat arkikieliset tai vanhentuneet termit. Sellaisia ovat verottaja,

\footnotetext{
6 Skat on myös sanaristikoissa usein esiintyvä korttipeli.

7 Virtaranta Amerikansuomen sanakirja (1992).

8 Myös ruotsissa tax tarkoittaa mäyräkoiraa.
} 
veronkantaja, vouti ${ }^{9}$, veromies ja verokarhu sekä niiden vastineet muissa kielissä.

Taide ja tiede ovat kansainvälisiä, ja niitä tehdään kaikilla kielillä. Tässä tutkimuksessa taidetta tarkastellaan suomalaisin silmin ja korvin hyödyntäen ennen kaikkea suomen kieltä. Aineistoa on Suomen lisäksi lähinnä Ruotsista, Saksasta, Britanniasta ja USA:sta, jolloin on turvauduttu myös ruotsiin, saksaan ja englantiin. Jonkin verran on hyödynnetty myös espanjaa.

\subsection{Taideverokirjan tarkoitus ja toteutus}

Verotuksen päätarkoitus on fiskaalinen eli valtion ja kuntien toiminnan rahoittaminen. Monia muitakin tavoitteita verotuksella on. Verotusta käytetään myös kulttuuripolitiikan välineenä; esimerkiksi taidetta tuetaan monilla eri aikoina säädetyillä verohelpotuksilla.

Taiteessa on samoja piirteitä kuin urheilussa. Urheilun verotuksesta on tehty jo vuonna 1984 oikeustieteellinen väitöskirja (Linnakangas: Urheilu ja verotus), jossa huomion kohteena olivat mm. aikoinaan tärkeät amatöörisäännöt. Urheilun verokysymyksiä on käsitelty sittemmin laajasti muissakin kirjoissa, artikkeleissa, opinnäytteissä ja vero-ohjeissa. ${ }^{10}$

Taiteen oikeudellisia kysymyksiä on tarkasteltu viime aikoina erityisesti Pauli Rautiaisen lähinnä valtiosääntöoikeudellisessa tuotannossa, jossa on vero-oikeudellisiakin liityntöjä ja myös Verohallinnon ohjeita. Verolakien kommentaareissa ja yleisesityksissä puolestaan on tarkasteltu taidetta ja taiteilijoita varsin suppeasti. Syvemmin teemaa on aikaisemmin tutkittu erillisartikkeleissa sekä Anderssonin ja

9 Vouti (ruots. fogde) on ollut valtion virkamies, jonka tehtäviin on kuulunut mm. verojen kantaminen. Voudilla on tarkoitettu myös esim. tilanhoitajaa tai tiettyyn tehtävään valittua luottamushenkilöä. Esim. Aleksis Kiven romaanissa ”Seitsemän veljestä" (1870) mainitaan Viertolan kartanon vouti ja toisaalta kyläläisten keskuudestaan valitsema jahtivouti. Silta- ja jahtivoutien palkkaamiseksi kerättiin aikoinaan myös erityistä silta- ja jahtivoudin kapoiksi kutsuttua veroa. Ks. tarkemmin esim. Wikipedia Vouti.

10 Ks. esim. Halila - Norros Urheiluoikeus (2017). 
Gyllströmin satasivuisessa kirjassa Kuvataiteilijan verotuksesta (1982), jonka esipuheessa todetaan:

Maamme taiteilijoita verotetaan usein epätyydyttävällä tavalla. Tämä johtuu käsittääksemme kolmesta eri syystä: Ensinnäkin lainsäätäjä ei ole ottanut huomioon taiteilijoiden erityisongelmia. Toiseksi veroviranomaiset, jotka eivät ymmärrä taiteellisen toiminnan erikoisluonnetta kuten esim. sen epäkaupallisia piirteitä, soveltavat eräitä voimassa olevia säännöksiä taiteilijoille epäedullisella tavalla. Kolmanneksi taiteilijat eivät itse ymmärrä vero-oikeutta eivätkä osaa laatia veroilmoituksiaan oikein.

On puuttunut sellainen tutkimus, jossa olisi käsitelty sekä verotuksen asemaa taiteissa että taiteen asemaa kaikissa taiteenlajeissa. Tässä kirjassa (II osa) tutkitaan, miten veroteema on esiintynyt ja esiintyy taiteissa. Osassa III, joka on kirjan laajin, selvitetään taiteeseen liittyviä verokysymyksiä verolajeittain seuraavassa järjestyksessä: tulo- ja varallisuusverotus, perintö- ja lahjaverotus, huvi- ja elokuvaverotus, arvonlisäverotus ja arvonimivero. Sen jälkeen IV osassa arvioidaan tapahtunutta kehitystä ja nykytilaa ja katsotaan tulevaisuuteen. Kirjan lopussa on luettelo viitatusta tutkimuskirjallisuudesta, oikeustapaushakemisto, teos- ja taiteilijahakemistot sekä asiahakemisto. Hakuteoksiin, Wikipediaan, lainvalmisteluasiakirjoihin, työryhmämuistioihin, viranomaisohjeisiin yms. lähteisiin viitataan vain alaviitteissä. 


\section{II \\ Osa}

\section{Veroteema taiteissa}

\subsection{Tehtävän tarkentaminen ja jäsentely sekä aineiston hankinta}

Seuraavaksi selvitetään, miten verotusta on käsitelty taiteen keinoin. Taiteiden veroesiintymiä tarkastellaan ennen kaikkea taidelajikohtaisesti seuraavasti:

- taulut ja patsaat,

- romaanit, elokuvat, rikossarjat ja kuunnelmat

- sadut,

- piirrokset, sarjakuvat ja sketsit,

- runot,

- laulut.

Aineistoa veroteeman esiintymisestä taiteessa on kirjan tähän osaan etsitty erityisesti netistä useilla hakusanoilla ( $\mathrm{mm}$. vero, tulli, tax, skatt, Steuer, sanat, lyrics). Hakutavastakin johtuen eniten osumia on kohdistunut lauluihin; veroliityntä löytyi yli sadasta laulusta, joista 
puolet suomenkielisiä. Apua on saatu mm. Wikipediasta, jossa on esitelty lähes kaikki tässä kirjassa mainitut taiteilijat ja heidän tuotantonsa. Suurimman osan lauluista on voinut kuunnella esimerkiksi YouTubesta, ja useimpien sanatkin ovat saatavilla netissä. ${ }^{11}$ Joidenkin kappaleiden hankinnassa on turvauduttu ystävien ja levykauppiaiden apuun. Hyvin vaikeaa oli löytää kuunneltavaksi Eino Virtasen vuodelta 1965 oleva kappale "Verotus on kauhistus"; se onnistui vain Kansalliskirjastossa. ${ }^{12}$

Verotusta on selvitetty monenlaisissa talous- ja oikeustieteellisissä tietokirjoissa, dokumenttielokuvissa ${ }^{13}$ sekä uskonnollisessakin kirjallisuudessa. ${ }^{14}$ Tuollaisia julkaisuja ei kuitenkaan käsillä olevassa kirjassa pidetä taideteoksina, eikä niitä sen vuoksi myöskään tämän kirjan II osassa käsitellä. ${ }^{15}$ Sen sijaan kirjan oikeustieteellisessä osassa III myös tieteellisellä kirjallisuudella on tärkeä rooli.

\subsection{Taulut, patsaat, muistomerkit ja rakennukset}

Menneiden aikojen veroista ja suurista verokapinoista muistuttavat $\mathrm{mm}$. vanhat piirrokset ja maalaukset, joita on käytetty useiden historiakirjojen kuvituksena. ${ }^{16}$ Verotusta kuvaa myös arvostettu taideteos "The Tax Collectors", jonka alankomaalainen taiteilija Quinten Massys

11 Monissa lauluissa sanat ääntyvät niin epäselvästi, että kuuntelija ei voi olla varma, mitä tarkoitetaan.

12 Tämä laulu mainitaan ensimmäisenä sellaisena suomenkielisenä äänitteenä, jonka nimessä on sana "vero". Sanojen ensiesiintymisistä suomenkielisissä äänitteissä (fi.wikiquote.org/wiki).

13 Amerikkalaisten Randy ja Betsy Cornerin kieltäytymisestä maksaa veroja sotamenoihin on tehty dokumenttielokuva "An Act of Conscience" (1997).

14 Jeesuksen syyttäminen Pilatuksen edessä koski myös veroprotestiin yllyttämistä: "Hän kieltää maksamasta veroa keisarille ja väittää olevansa Messias, kuningas" (Luukas 23:2). Vrt. Matteus 22:18-22: "Sano siis meille, mitä mieltä olet: onko oikein maksaa keisarille veroa vai ei?” [ - - ] "Antakaa siis keisarille mikä keisarille kuuluu ja Jumalalle mikä Jumalalle kuuluu.”

15 Tämän tutkimuksen ulkopuolelle jää mm. dokumentaarinen tv-sarja "Suomen Tulli”.

16 Esim. teoksessa Burg A World History of Tax Rebellions - An Encyclopedia of Tax Rebels, Revolts, and Riots from Antiquity to the Present (2004). 
(1466-1530) elämänsä viime vuosina maalasi kahdesta veronkantajasta. Taulua säilytetään nykyisin Liechtensteinissa. ${ }^{17}$

Verotukseen ei sen sijaan liity taidemaalari Paolo Veronalaisen tuotanto. Hän joutui inkvisition tutkittavaksi maalattuaan vuonna 1573 sopimattomana pidetyn taulun "Viimeinen ehtoollinen" mutta selvisi ongelmasta muuttamalla teoksensa nimeksi "Juhlat Leevin talossa". ${ }^{18}$ Paolo oli syntyisin Veronasta (siis Veronese), minkä vuoksi häntä on kutsuttu suomeksi myös Veronalaiseksi.

Perimätiedon mukaan talonpoika Lalli surmasi piispa Henrikin Köyliönjärven jäällä vuonna $1156 .{ }^{19}$ Lallia voidaan pitää ulkomaalaista verottajaa vastaan taistelleena veronmaksajain edustajana. ${ }^{20}$ Köyliöön on vuonna 1989 pystytetty Lallia esittävä Aimo Tukiaisen suunnittelema isokokoinen patsas. Siinä lämpimästi pukeutuneen Lallin vasemmassa kädessä on pitkä keihäs. Oikeassa kädessä Lalli pitelee suurikokoista lukkoa, ja kainalossa hänellä on iso kirves. Patsaan (kuva kirjan takakannessa) kustansi Köyliön Säästöpankki 100-vuotisjuhlansa kunniaksi.

Tampereen Hämeensillalla on neljä patsasta, joista yksi esittää alastonta veronkantajaa (kuva kirjan takakannessa). ${ }^{21}$ Veistokset lahjoitti Tampereen kaupungille kauppaneuvos Rafael Haarla, joka juhlisti näin oman teollisuuslaitoksensa 20 -vuotisjuhlaa. Hän ilmoitti vuonna 1923 kaupunginhallitukselle lahjoittavansa 100000 markkaa vastaisuudessa rakennettavan Hämeensillan kaiteiden taiteelliseen somistamiseen. Teokset tilattiin kuvanveistäjä Wäinö Aaltoselta. Ne valmistuivat kaupungin 150-vuotisjuhliin, ja ne sijoitettiin paikoilleen syyskuussa 1929. Patsaat esittävät 1200-1500-luvuilla vaikuttaneen pirkkalaisliikkeen sankarillisena myyttinä. Pirkkalaiset tekivät kauppa- ja eräretkiä pohjoiseen ja verottivat lappalaisia. ${ }^{22}$

17 Ks. Larry Silver Massys and Money: The Tax Collectors Rediscovered, Journal of Historians of Netherlandish Art.

18 Tarkemmin Rautiainen Kuvataiteilijan oikeudellinen asema (2012 (s. 10-11).

19 Ks. myös esim. IS.fi 19.1.2021 "Suomen kuuluisin murha nosti piispa Henrikin suojeluspyhimykseksi - mutta onko liki 900-vuotiaassa legendassa perää?"

20 Lalliin liittyy myös ikivanha runo, jota selvitetään jäljempänä luvussa 2.6.1.

21 Wikipedia Hämeensillan Pirkkalaisveistokset.

22 Pirkkalaisista esim. Voionmaa Suomalaisia keskiajan tutkimuksia (1912) s. 59 ss. 
Pirkkalaiset eli pirkkamiehet tai pirkat (ruots. birckarlar) olivat Tornion, Luulajan ja Piitimen pitäjissä asuneita, suurelta osin savolais-, karjalais- ja hämäläistaustaisia talonpoikia, joilla oli oikeus verottaa saamelaisia ja käydä kauppaa heidän kanssaan. ${ }^{23}$ Pirkkalaisten lapinverotuksen ja -kaupan juuret olivat rautakaudessa, mutta kirjallisissa lähteissä heidät mainitaan Lappia ja Peräpohjaa koskevissa hallinnollisissa asiakirjoissa 1300-luvun alusta aina 1600-luvun alkuun. ${ }^{24}$

Verotus oli yhtenä syynä 1590-luvulla käytyyn nuijasotaan, josta muistuttava Ilkan patsaaksi kutsuttu mukulakivistä rakennettu Matti Visannin suunnittelema monumentti pystytettiin Ilmajoelle vuonna 1924. Nokialla taas on Gabriel Engbergin suunnittelema graniittipaasi nuijasodan Nokian taistelun muistomerkkinä (1933).

Verotuksen näkymisestä rakennustaiteesta voidaan mainita Alvar Aallon vuonna 1954 Muuratsaloon valmistunut huvila. Sen sanotaan saaneen nimekseen "Koetalo", koska sen rakennuskustannukset koetettiin saada verovähennyksiin. ${ }^{25}$

\subsection{Romaanit, elokuvat, rikossarjat ja kuunnelmat}

\subsubsection{Suomalaisia romaaneja, näytelmiä ja elokuvia}

Suomen verohistorian tunnetuimpia nimiä on Simon Affleck eli Simo Hurtta, joka syntyi Narvassa noin vuonna 1660 ja kuoli Pielisjärvellä vuonna $1725 .{ }^{26}$ Hänet muistetaan suomalaisessa kansanperinteessä säälimättömänä ja julmana veronvuokraajana. Hän keräsi veroja

23 Pirkkalainen on siis eri asia kuin pirkkalalainen; pirkkalalaiset asuvat Tampereen kyljessä sijaitsevassa Pirkkalassa. Siitä, mistä tämän Pirkkalan nimi johtuu, on useita teorioita.

24 Ks. tarkemmin Wikipedia Pirkkalaiset.

25 Alvar Aallon rakkauselämästä ja urasta kertovan elokuvan (ks. areena.yle.fi/ 1-4586720) 55 minuutin kohdalla oleva maininta.

26 Ks. esim. Wikipedia Simon Affleck. Paljon viitteitä Simon Affleckiin on Katajalan vuonna 1994 julkaistussa väitöskirjassa Nälkäkapina - Veronvuokraus ja talonpoikainen vastarinta Karjalassa 1683-1697. 
kruunulta vuokraamallaan alueella nykyisen Lieksan seudulla, jossa häntä vastaan nousi useita talonpoikien kapinaliikkeitä. Hurtta-nimi tuli mahdollisesti siitä, että hänen sanottiin pitäneen veronkantoapuna isoa pelottavaa koiraa. Toisen tulkinnan mukaan nimi viittasi hänen omaan pelottavaan olemukseensa.

Simo Hurtta on esiintynyt useasti kaunokirjallisuuden aiheena. Anni Kepplerus julkaisi vuonna 1897 Affleckin kuvitteellisesta sukulaistytöstä kertovan historiallisen romaanin "Hovin Inkeri”. Eino Leino kirjoitti vanhojen tarinoiden pohjalta runoelman "Simo Hurtta" sekä vuonna 1908 samannimisen viisinäytöksisen historiallisen näytelmän. Sotakirjailija Onni Palaste on kirjoittanut Hurtasta kolmessa romaanissa: "Simo Hurtta" (1978), "Simo Hurtta ja Anna" (1982) sekä "Simo Hurtta ja isoviha" (1983). Mauri Sariola kirjoitti vuonna 2002 kirjana julkaistun jatkokertomuksen "Simo Hurtta ja kultainen pikari”. Eino Leinon näytelmän pohjalta valmistui vuonna 1940 myös elokuva "Simo Hurtta". Tauno Pylkkänen on säveltänyt vuonna 1948 kantaesitetyn oopperan "Simo Hurtta".

Verotusta on käsitelty muissakin historiallisissa romaaneissa. Santeri Ivalon vuonna 1909 ilmestyneessä kirjassa "Erämaan taistelu” kuvataan hämäläisten ja savolaisten kahakoita 1400-luvulla. Veronkantoon liittyy esimerkiksi seuraava romaanin kohta (s. 149):

Siellä oli rahvas kirkkomäellä koolla, kovin kiihtyneessä mielentilassa näkyivät olevan pitkähihaiset karjalaiset, kirjamiestä kyselivät. Heitä kuohuttivat ne uudet ja moninkertaiset verot, joita heiltä Viipurin linnanherra kiskotti, kahdet kesäverot se oli jo ottanut samana kesänä ja miehiltä oli loppunut luonto. Minä kuuntelin niitä heidän valituksiaan ja jopa heille kirjamieheksi rupesinkin. Sillä synkkää oli se komento, jonka alle he olivat joutuneet, jos olivat julmat Hannu-herran voudit Hämeessä, niin vielä sydämettömämmin liikkuivat Kristerin verohuovit Karjalassa.

Veroista on mainintoja useissa muissakin suomalaisissa teoksissa. Esimerkiksi vuonna 1909 julkaistussa Ilmari Kiannon kirjassa "Punainen viiva" on kohta, jossa Riika antoi miehelleen Topille kourallisen kuparirahoja ja pyysi Topia ostamaan tytölle punakukkaista kangasta leningiksi. Kun Topi ihmetteli, mistä Riika oli lantit saanut, niin Riikka vastasi karjalaiskieltä tavoitellen, että "Ryssän musikat Ruotshin akoille veroa masetah. Hospo miilui". Riikan vastaus kuuluisi kai 
suomeksi suunnilleen näin: "Ryssän miehet Ruotsin akoille veroa maksavat. Herra armahda." 27

Ensio Rislakin menestysnäytelmän "Kunnioittaen" kantaesitys oli Suomen Kansallisteatterissa vuonna 1952, ja teoksesta tehtiin vuonna 1954 myös elokuva. Kysymyksessä oli poliittisaiheinen komedia, jossa kansanedustajiksi pyrkivät Yleisen Vakauttamispuolueen ehdokas taloneuvos Elmeri Vara ja Vapaan Valistuspuolueen ehdokas rouva Selma Vuorinen. Verotus oli esillä kummankin vaaliohjelmassa. Taloneuvos Vara vaati suuriperheisille veronhuojennuksia, kun taas rouva Vuorinen, jonka tunnuksena oli "Rahaa, rauhaa, ravintoa", vaati veronhuojennuksia kaikille. Eduskuntaan ei valittu kumpaakaan, mutta tarinalla oli onnellinen loppu: Vara ja Vuorinen avioituivat keskenään.

Veroilla on ollut jonkinlainen rooli muissakin suomalaisissa viihdeelokuvissa. Esimerkiksi elokuvassa "Molskis, sanoi Eemeli" (1960) ulosottomies saapuu perimään 50000 markan veroa aikamiespoika Eemeliltä, joka joutuu lähtemään kaupunkiin ansaitsemaan verorahoja. Matkalla hänet heitetään 12 kertaa ulos linja-autosta. Päästyään vihdoin Helsinkiin Eemeli saa paikan vossikan apukuskina. Filmissä "Älä nuolaise" (1962) kaksi kaverusta voittaa veikkauksen täysosuman, mutta odottamiensa miljoonien sijaan he saavat tyytyä murto-osaan summasta. He päättävät hankkia lisää rahaa esiintymällä amerikansuomalaisina öljymiljonääreinä. Aihe on menettänyt ajankohtaisuutensa, koska veikkausvoittoja ei enää tuloveroteta vaan ne ovat arpajaisverotuksen piirissä.

Risto Jarvan hauskassa ihmissuhteita ja ympäristökysymyksiä käsittelevässä elokuvassa "Mies, joka ei osannut sanoa ei" (1975) pieni rooli oli myös verotuksella: kauppiasperheen asunto oli pantu verotussyistä alaikäisen lapsen nimiin, ja lapsi siihen vedoten äitinsä kehotuksesta eväsi isältä pääsyn kotiin. ${ }^{28}$

Vuonna 1980 valmistui suomalais-unkarilaisena yhteistyönä komediaelokuva "Tullivapaa avioliitto". Sen juoni liittyi pikemminkin avioliitto- ja matkusteluongelmiin kuin veroetujen tavoitteluun. Elokuva sai Unkarissa enemmän katsojia kuin Suomessa.

\footnotetext{
27 Kysy kirjastonhoitajalta -verkkotietopalvelu 17.10.2018.

28 Tapahtuma on elokuvan 81. minuutin kohdalla.
} 
Tarinassa budapestiläisen taksinkuljettajanaisen sulhanen muuttaa Ruotsiin, ja on keksittävä keino, miten morsian voisi vierailla hänen luonaan laillisesti ja palata aina takaisin Unkariin. Laiton loikkaus epäisi mahdollisuuden palata. Ratkaisuksi tulee kulissiavioliitto suomalaisen liikemiehen kanssa, mutta asiat mutkistuvat, kun tästä syntyykin unkarilais-suomalainen romanssi. ${ }^{29}$

\subsubsection{Ulkomaisia romaaneja ja elokuvia}

Robin Hood oli englantilaisen tarinaperinteen mukaan Sherwoodin metsissä, Nottinghamin kaupungin läheisyydessä joskus 1100-luvun lopulla tai 1200-luvulla elänyt lainsuojaton ja taitava jousimies, joka otti rikkailta ja antoi köyhille. Hänen arkkivihollisensa oli Nottinghamin sheriffi. Sheriffi kuvataan epäoikeudenmukaisena tyrannina, joka kohtelee paikallisia ihmisiä huonosti ja verottaa heitä kohtuuttomasti. Tarina perustuu enimmäkseen 1400-luvulta peräisin oleviin balladeihin, mutta Robin on mainittu sitä vanhemmissakin kirjoituksissa. Hänen historiallisuudestaan ei olla varmoja, mutta tarina saattaa pohjautua usean todellisen henkilön vaiheisiin. Robin Hoodin legendaa on kerrottu vuosisatojen ajan balladeissa, näytelmissä, kirjoissa ja elokuvissa. Nykyään Robin Hood elää taloustieteessä; puhutaan Robin Hood -ilmiöstä, jossa taloudellinen epätasa-arvo vähenee.

Rikollispomo Al Caponessa (1899-1947) on joskus nähty robinhoodilaisiakin piirteitä. Hänen elämäänsä liittyvän tv-sarjan ”Lahjomattomat" pohjana ovat tositapahtumat, mutta tarina on suurelta osin fiktiivinen. Vaikka Elliot Nessin joukko taisteli Caponen järjestöä vastaan, sillä ei ollut mitään tekemistä veropetosjutussa, josta Capone lopulta joutui vankilaan.

"Tuulen viemää" ("Gone with the Wind") 30 on yhdysvaltalaisen Margaret Mitchellin klassikkoromaani vuodelta 1936. Se kertoo varakkaan etelävaltiolaisen plantaasinomistajan tyttärestä ja tämän ihmissuhteista USA:n sisällissodan aikaan. Kirjan pohjalta tehtiin vuonna 1939 samanniminen elokuva, joka sai kahdeksan Oscar-palkintoa. Teosta on toisaalta myös arvosteltu rasistiseksi. Päähenkilöllä

29 Esim. Wikipedia Tullivapaa avioliitto.

30 Kirjasta ja elokuvasta tarkemmin esim. Wikipedia Tuulen viemää ja Gone with the Wind. 
on lemmensuhteiden lisäksi taloudellisia huolia mm. suurten maaverojen vuoksi. Tästä teoksesta onkin jäänyt elämään sanonta "Kuolema, verot ja lapsen syntymä! Koskaan ei ole sopivaa aikaa millekään niistä."

Herbert Ernest Bates (1905-1974) oli englantilainen kirjailija, jonka pääteoksena voidaan pitää vuonna 1958 ilmestynyttä kirjaa ”Darling Buds of May" ja sen seuraavina vuosina julkaistuja jatko-osia. Kirjoista tehtiin vuosina 1991-1993 Suomessakin suosittu mainio televisiosarja "Oi ihana toukokuu". Siinä kerrotaan maatilallaan elelevästä isosta perheestä, jonka liiketoimissa ei noudateta lakia turhan tarkkaan. Maatilalle lähetetään nuori ja ujo verotarkastaja. Perhe tarjoilee runsaskätisesti talon antimia, ja verotarkastajan arvomaailma menee kaikin puolin uusiksi: hän rakastuu tilan kauniiseen tyttäreen ja päätyy tarkastuskohteeseensa kotivävyksi. ${ }^{31}$

Verotarkastajiin liittyvistä romaaneista voidaan mainita myös australialaisen Peter Careyn teos "The Tax Inspector" (1991). Romaani kertoo oikeudenmukaisuudesta ja raskaana olevasta verotarkastajasta. Tämä selvittää korruptoituneen yrittäjäperheen ongelmia, jotka kirjassa ulottuvat veronkierrosta lapsen seksuaaliseen hyväksikäyttöön.

Verotarkastajasta kertoo myös japanilaisen Juzo Itamin elokuva "A Taxing Woman" (1987). Päähenkilönä on naispuolinen verotarkastaja, joka tutkii rakkaushotelliketjun omistajan epäiltyä veronkiertoa. Verotuksen lisäksi liikkeenharjoittaja ja verotarkastaja käsittelevät omien lastensa kasvatukseen liittyviä ongelmia. ${ }^{32}$

Verorikollisten ja veroviranomaisten lisäksi mm. verokonsulteilla on ollut filmirooleja. Esimerkiksi saksalaisen Syyttäjä-sarjan jaksossa (Ylen ykköskanavalla 30.5.2021) selvitettiin veroneuvojan surmaa, johon liittyi mm. viinien väärennyksiä, rahanpesua ja mustasukkaisuutta.

Vuonna 2018 valmistui elokuva "On the Basis of Sex", joka tuli seuraavana vuonna Suomen elokuvateattereihin nimellä "Oikeuden puolesta". Elokuva kertoo sukupuolten tasa-arvon puolustajana tunnetun tuomari Ruth Bader Ginsburgin uran alkuvaiheista. Verojuristina työskennellyt Ginsburgin aviomies näytti vaimolleen tapauksen,

31 Tarkemmin esim. Wikipedia Oi ihana toukokuu ja The Darling Buds of May.

32 Ks. Wikipedia A Taxing Woman. 
jossa äitinsä omaishoitajana toimiva mies ei saanut verovähennystä hoitajan palkkaamisesta äidilleen, koska laissa oletettiin omaishoitajan aina olevan nainen. Ruth Bader Ginsburg alkoi käydä läpi lakeja ja huomasi USA:ssa olevan 178 sellaista lakia, jotka syrjivät ihmisiä sukupuolen perusteella. - Suomessakin on aikaisemmin ollut useita sukupuolisidonnaisia verosäännöksiä, mutta nykyisin sellaisia on vaikea löytää.

\subsubsection{Kuunnelmat}

Kuunnelma on näytelmästä kehittynyt pelkästä äänestä koostuva taidemuoto, jossa näyttelijöiden esittämällä vuoropuhelulla kerrotaan tarina. Kuunnelman historia alkoi radiossa, ja radio on yhä kuunnelmien pääasiallinen lähetyskanava. Kuunnelmia voidaan kuitenkin levittää myös tallenteina ja netissä. ${ }^{33}$ Kuunnelmien uusia sukulaisia ovat äänikirjat, jotka toimivat samalla periaatteella kuin e-kirjat mutta joissa tekstiä lukemisen sijaan kuunnellaan äänitiedostolta.

Juice Leskinen kirjoitti Yleisradiolle vuonna 1984 tunnin pituisen kuunnelman "Ravintola Wunderbar", joka on ollut tammikuusta 2020 alkaen Yle Areenassa. Kuunnelmassa päihtyneet asiakkaat juttelevat ja sönköttävät valomerkkiin asti. ${ }^{34}$ Taustalla kuuluu myös iskelmämusiikkia. Iltaa viettämässä on paikallinen verojohtajakin, ei kuitenkaan viranomaisena vaan yksityishenkilönä. Kuunnelman esitteessä verojohtajaa luonnehditaan yhteiskunnalliseksi pahaksihengeksi.

Vuonna 1985 Yleisradio esitti kuunnelman "Arvaamaton arvonlisävero", joka on ollut heinäkuusta 2021 alkaen Yle Areenassa. Kuunnelma oli suomennos brittiläisten Edward Taylorin ja John Grahamin tekstistä. Esityksessä mm. kerrottiin arvonlisäverotusta koskevan opaskirjan painovirheestä, jossa verohallinnon yhteystiedoissa sana "suoraan" oli vaihtunut sanaksi "huoraan". Lavista puhuminen kyseisessä kuunnelmassa saattaa hieman kummastuttaa. Lavilla ei tässä

33 Tarkemmin esim. Wikipedia Kuunnelma.

34 Kuunnelman äänimaailma muistuttaa paikoin juopuneiden örinää. Kysymys ei kuitenkaan ole örinäksi kutsutusta aggressiivisesta laulutyylistä, jossa pyritään tuottamaan mahdollisimman epäinhimillistä ja jopa hirviömäistä ääntä pallealihaksen ja kurkunpään avulla. Wikipedia Örinälaulu. 
tarkoiteta esimerkiksi taiteilija Veikko Lavia vaan lisäarvonveroa eli arvonlisäveroa, jota nykyisin kutsutaan tuttavallisesti alviksi.

Tämä kuunnelma keskittyy lähinnä selvittämään tietyn panimon yhden myyntierän veroa 300 vuoden takaa. ${ }^{35}$ Panimon 1600-luvun lopulla verohallinnon henkilökuntatilaisuuteen myymästä oluesta näyttäisi vero jääneen aikanaan maksamatta. Alun perin mitättömän pienen veron arvo on vuosisatojen aikana lisääntynyt valtavaksi, mihin ehkä viittaa myös näytelmän nimessä oleva sana "arvonlisävero". Tutkimuksissa selviää, että panimo ei ollut saanut suoritusta myymästään oluesta, ja lopuksi ilmenee, ettei olutta ollut edes toimitettu. Missään vaiheessa kuunnelmassa ei tule puheeksi veron vanhentuminen.

\subsection{Verosadut}

\subsubsection{Mitä ovat sadut?}

Satu voidaan määritellä todellisen elämän ylittäväksi mielikuvitukseen vetoavaksi kertomukseksi, joka usein on tarkoitettu lapsille, mutta satu voi olla kirjoitettu myös aikuisille. Kirjallisuustieteessä sadut jaetaan kansansatuihin ja taidesatuihin. Kansansadut ovat anonyymejä kansanperinteen tuotteita, kun taas taidesadut ovat tunnettujen kirjailijoiden tekemiä ja usein taiteellisesti kunnianhimoisia.

\subsubsection{Zacharias Topelius}

Suomen tunnetuin satusetä on Zacharias Topelius. Hänen kirjaansa "Lukemisia lapsille" (1893) sisältyy "Hopearahan kertomukset", jossa mainitaan lyhyesti veroistakin:

Vuonna 558. Kauas Bosporan sinisen vedenpinnan ylitse loisti suuren Sofiankirkon kullattu kupukatto Konstantinoopelissa. Keisari Justinianus istui valta-istuimellansa ja kantoi veroa monelta hänen allensa kuuluvalta kansakunnalta. Hänen rahavartijansa kokoili suuret maljat täyteen kultarahoja rikkaasta Aasiasta; mutta tuosta ennen niin kopeasta Roomasta tuli hänelle vaan pieni maljallinen hopearahoja. Minä olin siinä maljassa

35 Nykyisin olutveroa pidetään niin Britanniassa kuin Suomessakin valmisteverona, mutta oluesta suoritetaan myös arvonlisäveroa. 
ja kuulin keisarin sanovan: missä on nyt Rooman loisto, koska ei minulle tuoda sieltä suurempia aarteita? Herra keisari, sanoi palvelija, Rooman loisto on mennyt, barbaarit ovat hävittäneet sen aarteet ja repineet maahan kauniit hovilinnat siinä kaupungissa, jota mainittiin maailman pääkaupungiksi. Keisari kääntyi pahoilla mielin pois ja näki kaksi munkkia, jotka tulivat, matkasauvat kädessä, vierailta mailta. He lankesivat polvillensa keisarin eteen ja tarjoten hänelle sauvojansa sanoivat: "Herramme, me pyydämme sinun katsomaan, mitä nämät sauvat sisältävät." Keisari avautti nuo ontelot sauvat ja löysi niistä aivan pieniä madonmunia. Silloin kirkastuivat hänen kasvonsa ja hän sanoi munkeille: "Te olette tehneet sangen hyvän työn, ja minä tahdon antaa teille suuren palkinnon, sillä näissä sauvoissa olette tuoneet silkkimadon munia Itämailta, joten me nyt voimme kutoa kotona kaikki nuo kauniit ja kalliit silkkikankaat, jotka meidän tähän asti on täytynyt ostaa ahneilta Persialaisilta." Ja keisari sekä kaikki kansa ylisti munkkeja tästä hyödyllisestä lahjasta. Sillä ihmisten valta on katoavainen, ja suuret sotasankarit jättävät jälkeensä verta ja raunioita; mutta rauhalliset keksinnöt ja hyödylliset toimet, joita ahkerat ihmiset maan päällä saavat aikaan, kantavat pitkiksi ajoiksi hedelmiä, tuottaen varallisuutta ja menestystä.

\subsubsection{Jonathan Swift}

Jonathan Swift (1667-1745) oli angloirlantilainen valistusajan kirjailija ja runoilija sekä anglikaanipappi. Swift tunnetaan n. 150 teosta käsittävästä proosatuotannostaan, mutta hän ehti myös kirjoittaa lähes 300 runoa. Erityisen hyvin hänet muistetaan alun perin vuonna 1726 ilmestyneestä satiirisesta allegoriasta "Gulliverin retket" (tai "Gulliverin matkat"). Kirja on neljään osaan jaettu allegorinen kertomus merimiehestä, joka joutuu sattuman ohjastamana kummallisiin maihin. Romaani oli alun alkaen suunnattu aikuisväestölle satiiriksi hallitsijoista ja koko ihmiskunnasta, mutta selkeytensä ja mielikuvituksellisen kerrontansa ansiosta se on saanut mainetta ahkeraan luettuna lastenkirjana.

Swiftin satiiri on terävimmillään kirjan kolmannessa osassa, jossa Gulliver matkustaa Laputaan ${ }^{36}$ ja sen naapurimaihin ja kohtaa omituisia tiedemiehiä. Tuossa osassa käsitellään myös verotusta. Seuraava sitaatti on J. A. Hollon suomentamasta vuonna 1988 ilmestyneestä 4. painoksesta (s. 220-221).

36 Espanjan kielen (la) puta on suomeksi seksityöntekijä. 
Kuulin kahden professorin erittäin kiihkeästi väittelevän siitä, miten voitaisiin mukavimmin ja tehokkaimmin kantaa valtiolle rahoja herättämättä alamaisissa tyytymättömyyttä. Toinen arveli, että olisi oikeudenmukaisinta verottaa paheita ja hullutuksia ja että kunkin henkilön suoritettava summa oli jätettävä hänen naapuriensa muodostaman lautakunnan märättäväksi. Toinen oli aivan vastakkaisella kannalla. Hänen mielestään oli asetettava veronalaisiksi ne ruumiin- ja sielunkyvyt, joita ihmiset itse pitivät arvokkaimpina; veromärän piti vaihdella riippuen puheenalaisten kykyjen erinomaisuuden asteesta, ja tämän seikan ratkaiseminen oli jätettävä yksinomaan henkilöiden itsensä asiaksi. Suurimman veromäärän tulisivat suorittamaan ne henkilöt, jotka olivat toisen sukupuolen suosiossa, ja summan ratkaisisi heidän nauttimiensa suosionosoitusten lukumäärä ja laatu, heidän oman ilmoituksensa mukaan. Sukkeluus, urhoollisuus ja kohteliaisuus joutuisivat nekin runsaan verotuksen kohteeksi, ja kannettava summa määriteltäisiin samalla tavalla, kunkin itse ilmaistessa, millainen määrä mainittuja ominaisuuksia hänessä piili. Kuntoa, oikeamielisyyttä, viisautta ja oppia sitä vastoin ei pitänyt ollenkaan laskea veronalaisiksi, koska nämä ominaisuudet ovat siitä merkilliset, ettei kukaan tahdo tunnustaa niitä lähimmäisessään olevan eikä pitää niitä arvokkaina itsessään.

Naisten verottamisen perusteena tuli olla heidän kauneutensa ja vaatetuksen aistikkuus, ja heidän piti nauttia samaa erioikeutta kuin miesten: saada itse arvostella itseänsä. Uskollisuutta, siveyttä, tervettä järkeä ja hyvää luonnonlaatua sitä vastoin ei sopinut ottaa huomioon, koska siten ei saataisi kokoon edes veronkantokulunkeja.

\subsubsection{Astrid Lindgren ja Janosch}

Astrid Lindgren (1907-2002) oli maailmankuulu ruotsalainen lastenkirjailija. Tunnetuin hänen luomistaan hahmoista on Peppi Pitkätossu. Lindgrenin kirjoja on käännetty yli sadalle kielelle, ja hän kuuluu maailman luetuimpien kirjailijoiden joukkoon. Veroista Astrid Lindgren, joka oli ollut kymmeniä vuosia sosiaalidemokraattisen puolueen kannattaja, kirjoitti Expressen-lehteen maaliskuussa 1976 sadun "Pomperipossa i Monismanien"; siinä satukirjailijalta perittiin $102 \%$ :n marginaaliveroa. ${ }^{37}$ Lindgrenin kirjoitus herätti Ruotsissa verojen vastustusta, ja saman vuoden vaaleissa Olof Palmen johtama

37 Astrid Lindgrenin satu on innostanut ruotsalaisen muusikon Lars Berghagenin levyttämään vuonna 2002 laulun "Pomperipossa”, jossa ei kuitenkaan mainita nimenomaisesti verotusta. 
sosiaalidemokraattinen puolue menetti valtansa ensimmäisen kerran 44 vuoteen. Verosäännöksiä uusittiin tämän jälkeen. ${ }^{38}$ Seuraavassa on lyhennelmä tuosta sadusta:

Nu skall jag berätta en saga. Den handlar om en människa, Pomperipossa kan vi kalla henne, för det brukar ju folk heta i sagorna. Hon bodde i ett land som vi kan kalla Monismanien, nånting måste vi ju kalla det.

Det fanns i Monismanien nånting som hette marginalskatt. Det betydde att ju mer pengar man tjänade, dess större del av dessa pengar skulle riksskattemästaren ha för att få ihop till välfärdskakan. Men mer än 80 à $83 \%$ ville han inte ta av någon, nej, för han var ju resonabel. "Kära Pomperipossa", sa han, "så där en 17 till $20 \%$ får du behålla själv och göra med vad du vill." Och Pomperipossa var innerligt nöjd med det och levde glad och lustelig. Ändock fanns det i landet många missnöjda människor som slog på sköldarna och gnydde över "det höga skattetrycket" som de kallade det. Det gjorde Pomperipossa aldrig, ingen i hela Monismanien hade någonsin hört henne gny det allra minsta över sina bidrag till välfärdskakan. Tvärtom, hon tyckte det var alltigenom bra och rättvist och hon tänkte att nog ska jag ge min röst för att dessa vise män ska få fortsätta att styra vårt kära Monismanien.

En vacker dag var de vise männen som styrde Monismanien samlade på ett slott som vi kan kalla Haga, eftersom det hette så, och på en kafferast antagligen, när de inte hade tid att räkna efter så noga, fattade de ett märkligt beslut som gjorde livet mer än lovligt knepigt inte bara för Pomperipossa utan också för många andra människor i Monismanien. Men om detta visste Pomperipossa i förstone intet. Inte förrän hon plötsligt tillfrågades av en god vän:

"Vet du om att i år är din marginalskatt $102 \%$ ?"

"Du pratar", sa Pomperipossa. "Så många procent finns ju inte!"

För hon var inte särskilt hemma i den högre matematiken nämligen.

Jo då, fick hon höra, i Monismanien fanns det hur många procent som helst, och om man la ihop inkomstskatten och de sociala avgifter som Pomperipossa skulle betala, eftersom hon var egen företagare, så blev det $102 \%$, sen fick Pomperipossa säga vad hon ville! Arma Pomperipossa, där satt hon och skrev och gnetade så flitigt och visste inte ens att hon var egen företagare.

Mer och mer tänkte Pomperipossa i sin vrå. Hon kom ihåg Josef $i$ Egypten, han som så bra hade förstått att man under de feta åren måste sörja för de magra åren som kunde väntas komma. Så klok hade Pomperipossa minsann också varit. Hon hade tagit pensionsförsäkringar, rätt höga. Det

38 Ks. mm. Wikipedia Pomperipossa i Monismanien. 
är rimligt, hade hon tänkt, att jag sörjer för min ålderdom. När pennan faller ur min darrande hand och jag inte kan skriva längre, då vill jag ju inte ligga samhället till last. Har jag då dessa pensionsförsäkringar, så har jag mitt levebröd, även om jag naturligtvis måste betala skatt på det belopp som faller ut. Men det blir då det! För de vise männen som styrde Monismanien hade helt förnuftigt bestämt att premierna för dylika pensionsförsäkringar skulle vara avdragsgilla.

Vad är det som har farit i dom, tänkte Pomperipossa i sin mörka vrå. Är detta verkligen de vise män som jag beundrade och värderade så högt? Vad är det de strävar efter att åstadkomma - ett samhälle så vrångt och omöjligt som möjligt? $\mathrm{O}$, du min ungdoms rena blossande socialdemokrati, vad har de gjort med dej, tänkte hon (för nu började hon bli lite patetisk), hur länge ska ditt rena namn missbrukas för att skydda ett maktfullkomligt byråkratiskt orättfärdigt förmyndarsamhälle? Hon hade trott att i ett demokratiskt land skulle allas rätt värnas. Människor skulle inte straffas och förföljas bara för att de på hederligt sätt - med eller mot sin vilja - råkade tjäna pengar. Men det var, såvitt Pomperipossa kunde förstå, vad som pågick nu. Så här kan det inte få vara, för då tar all företagsamhet slut $\mathrm{i}$ vårt land och där blir inga egna företagare kvar att beskatta.

Det var mer Pomperipossa hann tänka i sin mörka vrå! På den gamla goda tiden, när marginalskatten var högst $83 \%$, då fanns det också något som hette "periodiska understöd". Det betydde att om man - som Pomperipossa på den gamla goda tiden - hade något mer pengar än man behövde för livets nödtorft och hade några mindre välförsedda anhöriga eller andra människor man brydde sej om, så kunde man ge dom ett periodiskt understöd. Sådana understöd fick man nämligen göra avdrag för i sin deklaration, och bara därför var det möjligt att ge dem.

Och Pomperipossa tog fram och läste om igen en liten vers, som en av Monismaniens yppersta skalder nyligen hade skrivit:

Att du skapar ett värde kan samhället icke tåla,

byråkraternas tjafs är du skyldig att delta $\mathrm{i}$,

du skall hjälpa Castro att föra krig i Angola

eller ock skall du sitta på gubbhus och få terapi.

Astrid Lindgrenin kritiikin kohteena siis olivat kohtuuton marginaaliveroprosentti, yrittäjän eläkevakuutusmaksut ja niiden verokohtelu sekä toistuvaisavustuksen verovähennyskelpoisuuden lopettaminen. ${ }^{39}$

39 Suomessakin toistuvaisavustuksen edullinen verokohtelu oli poistettu vuonna 1975 voimaan tulleilla säännöksillä. 
Janosch (oik. Horst Ecker) on kirjoittanut ja piirtänyt vuonna 1980 julkaistun suositun lastenkirjan ”Aarretta etsimässä”. Siinä pikku tiikeri ja pikku karhu ajattelevat, että maailman suurin onni on rikkaus. Sitä varten he etsivät aarretta ja vihdoin he löytävät kultaomenia. Sitten paikalle tulee virkamies ottamaan kuninkaalle säädetyn osuuden eli verottamaan, jopa moneen kertaan. Näin karhu ja tiikeri menettävät löydöstään yhteensä 87,5\%; loput vie varas, jolta kuninkaan piti heitä suojella. Sadulla on kuitenkin onnellinen loppu: onni ei nimittäin ole rikkaus vaan ystävät ja toisten auttaminen.

\subsection{Piirrokset, sarjakuvat ja sketsit}

\subsubsection{Pilapiirrokset ja verokarhu}

Meillä on julkaistu ja julkaistaan jatkuvasti hyvin paljon verotukseen liittyviä ajankohtaisia poliittisia pilapiirroksia. ${ }^{40}$ Niitä teki myös pilapiirtäjä Kari Suomalainen (1920-1999) Helsingin Sanomissa. Hänen piirrostensa yhteiskuntaelämä oli pitkälti poliittisen eliitin (tai virkamieseliitin) ja kansalaisten välistä kamppailua. Kamppailu tosin oli yksipuolista, koska Karin piirroksissa kansalainen usein alistui vastaan panematta hallituksen mielivaltaan; eliitti huolehti omista eduistaan veronmaksajien kustannuksella. Veroilla ahdisteltu kansalainen oli yleensä kaupunkilainen palkkatyöntekijä, eikä verokarhu Karin kuvauksissa juuri kouraissut maanviljelijöitä. ${ }^{41}$

Uusista pilapiirtäjistä mainittakoon esimerkiksi Ville Ranta. Hänet muistetaan mm. lentoveroaiheisesta piirroksesta (2019), jonka tekstissä pohditaan keinoja vähentää matkustajien (pahanhajuisia) päästöjä. Myös Seppo Leinonen on tehnyt useita veroaiheisia piirroksia.

Vaikka suomen verokarhu-sana tulee ruotsista (björna=karhuta), "skattebjörn" on Ruotsissa melko harvinainen. ${ }^{42}$ Saksassa "Steuerbär"

40 Piirroksia löytyy netistä esim. hakusanoilla "pilapiirros" ja "vero".

41 Näin Marja Ylönen Suomalainen, Kari Kansallisbiografia 13.10.2020.

42 Verokarhu sai 19.7.2021 googlella n. 308000 osumaa; skattebjörn sai vain n. 3000 , ja niistäkin suuri osa oli Suomen puolelta. 
on miltei tuntematon; ${ }^{43}$ siellä verottajasta käytetään nykyaikana yleisesti termiä "Elster", harakka. Suomessakin harakkaa syytetään varastelusta. Elster on Saksassa myös lyhenne termistä Elektronische Steuererklärung.

Suomen merkittävimpiä verokarhupiirtäjiä on kirjailija Mikko Kunnas (s. 1962). Hän on kuvittanut ja käsikirjoittanut mm. sarjakuva-albumin "Verokarhu.fi - Verotuksen alkeet" (2014), jossa päähenkilö on metsänväkeä verottava karhu. Mikko Kunnasta itseään voidaan sanoa verokarhun pennuksi, koska hänen isänsä oli Huittisten verojohtaja. Mikko Kunnaksen kirja on erittäin kattava. Pienestä koosta (56 sivua) huolimatta siihen ovat mahtuneet seuraavat verot: perintövero, huvivero, kiinteistövero, arvonlisävero, metsävero, progressiivinen tulovero, alkoholivero, ennakkovero, suojeluvero, paitavero, autojen verot, kalastusverot ja lentokenttävero. Albumin alussa käsitellään tapausta, jossa rikas Nallekarhu on lähtenyt veroja pakoon Ruotsiin, mutta esillä ovat muutkin veropakolaiset. Kunnaksen kirjan teksti on suurelta osalta runomitassa, usein vanhaa tuttua sanontaa muuttaen, kuten seuraavat esimerkit osoittavat:

Kun aika sielut ruumiista erottaa, ${ }^{44}$ niin silloin Nalle kuolinpesät helposti verottaa.

Viekää vaikka hunajat pesästä, ${ }^{45}$

mutta tämä poika nauttii kesästä.

Piirroksilla on usein elävöitetty verotusta koskevia artikkeleja. Verokarhu esiintyy joskus myös juridisten verotuskirjojen kansissa. Esimerkiksi Edward Anderssonin ja Katy Gyllströmin kirjan Kuvataiteilijan verotuksesta (1982) kannessa, jonka on piirtänyt Katy Gyllström, taiteilijan ja verokarhun välinen taistelu vaikuttaa jääneen kesken. Esko Linnakankaan, Leila Juannon ja Päivi Laatikaisen teoksen Arvonlisäverotus ja muu uusi kulutusverotus (1994) kannessa

43 Vain n. 3000 osumaa.

44 Mallina lienee anekauppa. Ks. siitä Linnakangas - Juanto Synti- ja haittaverokirja - Anekaupasta paheveroihin ja kompensaatiomaksuihin (2020) s. 17 ss.

45 Mallina lienee tuhkan vieminen pesästä, joka liittyi salpietariveroon. Ks. Linnakangas - Juanto Verojen historia - Synty, kehitys, kuolema, ylösnousemus, reinkarnaatio (2016) s. 36 ss. 
(tekijä Timo Huhtala) verokarhulla on toisessa kädessään miekka ja toisessa suuri rahasäkki; ilmeisesti veronkanto on onnistunut. Liisa Mariaporin kirjan Verottaja tappolinjalla (1998) kannessa (tekijä Katri Paakkari) sen sijaan voitonriemuinen verovelvollinen näyttää kaataneen verokarhun.

Veroaiheiset piirrokset ovat erittäin kiinnostavia. Niiden laajempi esittely sopii kuitenkin kuvateoksiin paremmin kuin käsillä olevaan tutkimukseen.

\subsubsection{Verotarkastajat, verokonsultit ym.}

Verokarhun lisäksi rooleja on piirretyissä annettu joskus myös verotarkastajille ja muillekin veroasiantuntijoille. Saksalaisessa salapoliisisarjassa Nikke Knatterton on mukana myös verotarkastaja Nuusku. ${ }^{46}$ Jaksossa "Tiirikoita, turvasäilöjä ja tekijöitä" erään yhtiön tulos romahti Nuuskun käynnin jälkeen, minkä seurauksena yritys joutui turvautumaan rikolliseen varainhankintaan.

Saksassa Walther Keim ja Klaus Saalmann ovat vuonna 1994 toimittaneet teoksen "Krötenwanderung ${ }^{47}$ - Karikaturisten sehen Steuerstress und Steuerrecht in Deutschland”. Tähän piirroksin ja tekstein varustettuun kirjaan on kerätty verotusta koskevaa huumoria monista lähteistä eri ajoilta.

Sketsi (engl. sketch) on tavallisesti tilannekomiikan varaan rakentuva, yleensä kestoltaan lyhyt komediallinen esitys (ks. esim. Wikipedia). Nykyään sketsejä esitetään tavallisesti internetin videopalveluissa, televisiossa, radiossa tai sopivissa tilaisuuksissa. Sketsin avulla voidaan esimerkiksi parodian keinoin käsitellä asioita ja ilmiöitä. Useasti sketsit rakentuvat jonkin kärjistetyn tai epätavallisen tapahtuman varaan. Tavallista on yhdistää sketsissä asioita, joiden ei yleensä kuvitella liittyvän toisiinsa, ja näin rakentaa huvittava tilanne.

Vuoden 2020 sketsihahmoksi valittiin mm. Putous-sarjassa esiintynyt virolainen talouskonsultti Urmas Viilunk, jota esitti Mikko Töyssy. Viilunkin tärkein hokema oli "Alvi pitää maksaa aina, muuten

46 Hahmosta ja sen luojasta ks. Wikipedia Nikke Knatterton.

47 Kröte on suomeksi (rupi)konna. Kirjassa on kuva, jossa konnat vaeltavat maarajan alitse Saksasta Luxemburgiin. 
verottaja laittaa myrskynhyrskyn”. Sen sijaan muusta veronmaksusta voitiin Viilunkin mukaan tinkiä, ja mm. palkkojen maksaminen pimeästi oli suotavaa. Ohjelmasta ei selviä, perustuivatko neuvot esimerkiksi Viron verojärjestelmän erityispiirteisiin.

Arvonlisävero on ollut esillä myös Jope Ruonansuun Jopet-show'ssa: rautakaupan kirjanpitäjä tulee lääkäri Kaikkosen vastaanotolle ja valittaa mm. sitä, että arvonlisäverot ovat maksamatta. Potilas saa sairaslomaa.

Tamperelaisen Kummeli-ryhmän televisiosarjassa on esiintynyt verotarkastaja, joka huomasi yrityksen jättäneen arvonlisäveroja maksamatta ja tehneen virheellisiä vähennyksiä (yksityiskäyttöön menneet tavarat ja mahdottoman suuret kilometrikorvaukset). Yritys selvisi ongelmista antamalla verotarkastajalle rakennustarvikkeita ym. tavaroita.

Verotarkastajalla on ollut rooli myös Spede-show'ssa. Tarkastuksessa selviteltiin mm. sitä, olivatko yhtiön omistajien golf-kustannukset verotuksessa vähennyskelpoisia. Verovelvollisten mielestä vähennyskelpoisuus oli selvä, koska peluu tapahtui vain työaikana. Tarkastuksessa oli esillä myös hartiapankkiveron määrääminen, koska osakkaat eivät olleet nostaneet palkkaa vapaa-ajalla tekemästään työstä.

\subsection{Runot}

\subsubsection{Pyhän Henrikin surmavirsi ja Kalevala}

Ehkä vanhin veroruno Suomessa on "Pyhän Henrikin surmavirsi”. ${ }^{48}$ Se on merkitty muistiin 1600-luvulla, mutta sen alkumuoto lienee peräisin 1200-luvun lopulta. Tuntemattoman runoilijan tekstissä kerrotaan, miten piispa tuli palvelijoineen talonpoika Lallin taloon ja vaati emäntä Kertulta kestitystä. ${ }^{49}$ Kerttu kuvasi tapahtuman miehelleen alla olevalla tavalla. Julmistunut Lalli hiihti piispan perään ja surmasi hänet Köyliönjärven jäällä.

48 Tarkemmin esim. v. 2002 ilmestynyt Katajalan kirja Suomalainen kapina Talonpoikaislevottomuudet ja poliittinen kulttuuri Suomessa Ruotsin ajalla (n. 1150-1800) s. 93 ss. ja Tarkiainen Ruotsin itämaa - Esihistoriasta Kustaa Vaasaan (2010) s. 78 ss.

49 Runo on erittäin pitkä, ja siitä on myös uudempia versioita. 
Lalloi cujn sitten tulli kotihin walehteli wanha naara ja sanoi pojkaiseni nuorempanj jopa on täsä sitten käynyt ruoka Ruotzin Syömä Saxa otti kakon uunjn pääldä otti ollutta kellärista heitti tuhkia sijahan heinät hejnä huonehesta kaurat kaura hingalosta heitti tuhkia sijahan.

Ruokaruotsi (ruots. gingärd) oli sen veron nimi, joka liittyi matkalla olleen piispan ja hänen seurueensa huoltoon. Saksa (ruots. trantysk) tarkoitti henkilöä, joka kierteli pitäjässä keräämässä voiveroa. Veronkantajan ammattiin liittyvä nimi viittaa siihen, että tämä henkilö ei ollut suomalaista syntyperää. Kyseessä saattoikin verokapina, jossa Lalli ja Kerttu eivät hyväksyneet ulkomaalaisten kantamia veroja.

Elias Lönnrotin 1800-luvulla kokoamassa "Kalevalassa" veroliittymä on Kullervosta ${ }^{50}$ kertovassa 35. runossa. Sitä on kuitenkin vaikea löytää, koska sanan "vero" sijasta käytetään sanaa "veto". ${ }^{1}$ Kun Kullervosta ei ole muihin töihin, isä lähettää hänet viemään veroja, jotka tuohon vanhoina aikoina maksettiin luonnontuotteina: ${ }^{52}$

Ei sinusta tarpojaksi,

Tarvoit nuotan tappuroiksi,

Ruumeniksi pullot rouhit,

Selykset paloin paloitit;

Lähe viemähän vetoja,

Maarahoja maksamahan!

Lienet matkassa parempi,

Taipalella taitavampi.

50 Katajala on ottanut kirjansa "Suomalainen kapina - Talonpoikaislevottomuudet ja poliittinen kulttuuri Suomessa Ruotsin ajalla (n. 1150-1800)" kanteen Gallen-Kallelan maalauksen "Kullervon kirous". Katajalan mukaan (s. 5) "Kullervo ilmentää aiheen kannalta olennaisia asioita: voimakas väärin kohdelluksi tulemisen kokemus, viha yhteisön ylempiä kohtaan, vimmainen huuto ja protesti metsästä”.

51 Kysymyksessä ei ole kirjoitusvirhe, vaan veto on kansankielessä merkinnyt myös veroa. Vilkuna Veto, veikka ja maanrahat, Virittäjä 1959 s. 452-465.

52 Kysymys oli ns. veroparseleista. Jonkinlaisena veroparselina voidaan pitää myös sellaista ihmisveroa, jossa maksu suoritetaan luovuttamalla hallitsijan käyttöön sotilaita Ihmisveron käsitteestä esim. Kujala Voudintileistä veroparatiiseihin (2021) s. 13 . 


\subsubsection{Nuijasota ja Kaarlo Kramsu}

Kuten jäljempänä laulujen yhteydessä selvitetään, vuosina 1596-1597 käydyn nuijasotana tunnetun talonpoikaiskapinan syynä oli myös verotus. Nuijasotaan liittyy Kaarlo Kramsun runo "Ilkka" (1878). ${ }^{53}$ Siitä siteerataan yleensä seuraavaa kohtaa, jossa korostetaan toimintaa valittelemisen sijasta; varsinaisena verorunoilijana Kramsua ei kuitenkaan voi pitää.

Vaan koska kansa valittaa,

Hän neuvon sille antaa:

"Niin kauan huolta nähdä saa,

Kun tahtoo sitä kantaa."

"Ken vaivojansa vaikertaa,

On vaivojensa vanki,

Ei oikeutta maassa saa

Ken itse sit' ei hanki."

\subsubsection{Eino Leinon runot}

Vuonna 1903 Eino Leinolta ilmestyi Helkavirsissä runo "Orjan poika", joka liittyy pirkkalaisten suorittamaan veronkantoon ${ }^{54}$ Lapissa. Siinä on $\mathrm{mm}$. seuraavat kohdat:

Puhui Pirkka puuhkalakki:

"Hoi miehet, ylös urohot, satanut on uutta lunta, läkkäme Lapin kylihin, Lapin lasta velkomahan!”

Palasivat pirkkalaiset, pulkat täynnä turkiksia, vempelet verohelyjä. ${ }^{55}$

53 Siitä on myös sävellettyjä ja laulettuja versioita.

54 Pirkkalaisten veronkannosta Lapissa tarkemmin edellä luvussa 2.2.

55 Verohelyn sijasta tutkijat käyttävät yleensä sanaa veroparseli. Ks. esim. Lindgren Maaverojen ja yritysverotuksen kehitys - Veroparseleista ja suostunnasta kansainväliseen verokilpailuun, Verotus 1865-2015 - Näkökulmia suomalaiseen verotukseen, Verohallinnon julkaisu (2015) 
Edellä on romaanien yhteydessä käsitelty Simo Hurttaa ja mainittu mm. Eino Leinon Hurtta-kirjoituksista. Seuraavassa on joitakin kohtia Leinon runokokoelmasta "Simo Hurtta - runoja Isonvihan ajoilta" (1904).

Pulma tää on hiidenmoinen, joka miettimistä antaa: esivalta tääll' on toinen, toinen kruununverot kantaa. Maa on Ryssän, voudit Ruotsin, kirkko itse pirun, - luon ma yöhön yhden lujan luotsin: kuninkaan nyt maljan juon ma.

Vaikka pappi meidät petti, pettää piru pappi pahan, vaikka Hurtta kansan ketti, ketämme me Hurtan nahan; käyköön, kuinka käykin, laihdu eivät voudit, tiedän tuon ma, eikä veronkanto vaihdu: esivallan maljan juon ma.

Juodaan malja. Jessenhausi yhä yksin motkottavi:

"Arnkil aivan oikein lausi; kenpä tässä kotkottavi, senpä syykin olla suittaa: juovuksissa verot kantaa, puolet kurkkuhunsa kuittaa, toiset puolet anteeks antaa."

Eino Leino julkaisi elämänsä ehtoopuolella vuonna 1924 lyhyen runon "Löysäläisen laulu":

Maantietä matkaa kirjaton, karjaton mies.

Kruununkin kyyti liikaa ois hälle kenties,

Outoja hälle kun on isänmaa, kotipaikka ja lies,

Puolue, perhe ja muu, verot, verka ja velka ja ies. 
Löysäläinen (ruots. lösdrivare) tarkoitti irtolaista. Heitä varten oli omaa lainsäädäntöäkin aina 1980-luvulle asti. Irtolaisella tarkoitettiin mm. yhteiskunnan ulkopuolelle jättäytyneitä, prostituoituja ja kerjäläisiä. Kun irtolaisilla ei aikoinaan ollut laillisia tuloja eikä omaisuutta, ei heitä voitu verottaakaan.

\subsubsection{Veroaiheisia käyttörunoja}

Käyttörunouden päätarkoitus on muu kuin esteettisen nautinnon tuottaminen; se voi olla esimerkiksi tilaisuuden tai tapahtuman juhlistaminen tai historiasta kertominen. Jotkut runoilijat ovat käyttäneet taiteellisia taitojaan myös kirjoittaessaan veroviranomaisille. Aaro Hellaakosken kerrotaan vastanneen 1940-luvulla runomitassa ns. hetekaveroa koskevaan tiedusteluun. Pietarsaarelainen Viktor Sund (1891-1966), jonka runoja mm. Oskar Merikanto sävelsi, taas vastasi saamaansa koiraverotiedusteluun seuraavasti: ${ }^{56}$

Ingen katt

Ingen hund

Ingen skatt

Viktor Sund.

Vammalassa (nyk. Sastamala) asunut Onni Kallio (1922-1999) on julkaissut suuren määrän riimejä ajankohtaisista tapahtumista. Joukossa on myös pari 1980-luvun lopun kokonaisverouudistukseen liittyvää esitystä. ${ }^{57}$ "Remonttihommia" (sävel "Väliaikainen") sisälsi mm. seuraavat kohdat:

Nyt on verot sitten remontissa uudelleen niitä liiaksi kai kaikilla lie

Sai Liikanen Puolanteen puolelleen

liiat markat he varmasti vie

56 Viktor Sundin runoista tunnetuin on Jussi Snellmanin suomentama "Miss' soutaen tuulessa koivut sorjat soi", jonka sävelsi Oskar Merikanto. Tuo kappale kuultiin myös elokuvassa "Tullivapaa avioliitto" (1980).

57 Onni Kallio, Ajatuksia ja kommentteja (1995) s. 45-46 ja 103-104. Verouudistus mainitaan ohimennen myös saman julkaisun "Viikon viisussa" (sävel "Puusepät”). 
Palkkapussia pitäs sitten helpottaa

Kapitaalia passaa kyllä riepottaa

Mutta sitten kun vähennykset pannaan pois

veroilmoitus helppoa ois.

Veropohjaa kun pitäs siinä laajentaa

kaikki kaapia kuopista pois

Monta semmosta lähdettä ammentaa

joita muuten ei hoksattu ois

Siispä joukolla kohteiden etsintään

Sänkyvero! Voi hitsi minkä keksinkään ${ }^{58}$

Postilaatikko, vessa ja porkkanamaa,

verokohteiksi sitten vaan.

Presidenttikin kepsusta ${ }^{59}$ palkastaan

verot joutuisi makselemaan ${ }^{60}$

Toki aate on ehdotus ainoastaan

jota jäämme nyt katselemaan

Sitä hallitusjoukot nyt runtata saa

sitä oppositio työksensä vastustaa

mutta voisko sitä Koivisto vahvistaa

kun verot häntäkin ahdistaa.

Verouudistustyössä on vaihetta

monta uutta ja autuuttavaa

Ilokekruihin vielä ei aihetta

sitten vasta, jos tuntee sen saa

Kyllä jostakin aina sua nyhjätään

verolappua kouraas' saat yhtenään

Lopputulos: Lähes jokainen saa järjestään

lisämaksua entisestään.

58 Suomen verohistoriassa tunnetaan ns. hetekavero. Kysymyksessä oli 1940-luvulla peritty ylimääräinen omaisuusvero. Hetekaverosta puhuminen selittyy hetekoiden silloisella yleisyydellä ja sillä, että kyseisen veron piirissä olivat myös huonekalut. Tarkemmin esim. Linnakangas Korvamerkkiverot, vapaaehtoiset verot ja veron kirnuaminen, Defensor Legis 4/2018 s. 656 ss.

59 Kepsu tarkoittaa Nykysuomen sanakirjan (1983) mukaan huonoa. Kielitoimiston sanakirjassa (2006) kepsu ei esiinny.

60 Tasavallan presidentin palkkio on yhä verovapaa. 
Samaisen miehen riimityksessä "Verotus keveni” ${ }^{61}$, joka voidaan laulaa samalla sävelellä kuin ”Paljon on kärsitty vilua ja nälkää”, ensimmäiset säkeistöt kuuluvat seuraavasti:

Kaikillehan kauan on jo hyvää mieltä tuotu verotusta keventämään lähdettiin.

Kaikenlaista toimikuntaa sitä varten luotu hallituskin siihen hommaan säädettiin.

Helppoo oli kaikki tää ohjelmaksi määrittää:

Verotusta kaikkialla keventää.

Kaikessa vaan paha kanto oli yksi tässä, menoja kun jostain ain' on löytynyt. Etua jos toistakin on kaikki nyhtämässä, eduskuntakaan ei tyhjään tyytynyt. Menot kun on kasassa se määritellään rahassa ja verotus on pintehessä pahassa.

Töitä teki Erkki sekä töitä teki Ulla meni siinä kuukausi jo toinenkin. Tuloja kun etsiskeltiin syväluotailulla kiirekin jo tuli jonkinmoinenkin. Nyt se sitten homma tää kansalaista tyydyttää, hallitus kun verotusta keventää.

Taloustieteilijä Vesa Kanniaisen alla oleva veropoliittinen runo on vuonna 2005 ilmestynyt VATTin julkaisemassa kirjassa "Verotus, talouspolitiikka ja kansantalous", joka tehtiin Jouko Ylä-Liedenpohjan syntymäpäivän kunniaksi.

61 Pääministeri Harri Holkerin hallitus jakoi vuonna 1987 jokaiseen kotiin hallituksensa sinimustan tiedotteen "Verotus kevenee". Tiedotteessa kerrottiin hallituksen esityksestä verotuksen uudistamiseksi. 
Näki unta tuo tutkija luova, näin aprikoi, oli syntynyt neutraali vero.

Kulutuksen veropohjaksi kun valikoi, oli lainlaatija taitava, melkeinpä nero.

Nyt kulkevi konkaavi kulku, huipulle Hamiltonin, teille maan murheisille, tuo tiedon uuden, on se juurilta jumaluuden. Te elätte keskellä viisauden merta, tuhatkertaista tiedon raitaa. Vaan tietäkää: silti, verot neutraalit unimaailmaan ne jäädä taitaa. Jo nouseva aamu unelmat murskata voi, Tuloveron tahdissa aurinko nousee, kun koittavi päivän uusi koi.

Verohallinnon Instagram-tilillä on vuodesta 2018 alkaen julkaistu runomuotoisia ohjeita verolomakkeiden käyttöön. Runomuotoiset viestit ovat hauska lisä, eivätkä ne ole syrjäyttämässä normaalilla virkakielellä annettavia ohjeita. Tässä esimerkkinä kaksi verolomakerunoa:

\section{Pankkitilin ilmoituslomake}

Jos veronpalautusta mielesi halajaa, pankkitilin numerohan se mieleen palajaa.

Kun tänään euroja kansalle siirtyy miltsiä sen kahdeksansataa, joku ottaa väistämättä pataan

- ei ole tilinumero oikea, ja veronmaksajan mieli on harmista soikea.

Mutta huoli pois, oi kansan rivi syvä, on meillä teille uutinen hyvä.

Vaikka mieli tekis soittaa, kannattaa OmaVeron lempeää syleilyä koittaa.

Naputa tilinumero kohdilleen siellä, niin ei tarvitse pettymyksen karvasta kalkkia niellä.

\section{Verolomake 15 (taiteilijan ja freelancerin tulot)}

Cuten Mikael Agricola sanoy, Sange hyue ombi wero anda, ette sen cautta Rauha pidheten, Pahus esteten ja hywuys wariellan. Elkette sentedhen nerckestykö. Elkette waikka olisidte: Taitelija tahi freelancer. 


\subsection{Laulut}

\subsubsection{Vallankumous- ja työväenlaulut}

Verot kerättiin aikaisemmin erityisesti talonpojilta, ja ankara verotus oli usein syynä talonpoikien kapinoihinkin. Näin on ollut myös meillä. ${ }^{62}$ Parhaiten muistetaan vuosina 1596-1597 käyty nuijasota, joka liittyi mm. linnaleirijärjestelmään. ${ }^{63}$ Linnaleiri oli Ruotsin valtakunnassa käytössä ollut järjestelmä, jolla sotaväki majoitettiin sotaretkien väliajoilla ja erityisesti talvisin kruunun ja aatelisten linnoihin, linnoituksiin ja varakkaisiin taloihin. Suomen alueella 1570-luvulla Venäjää vastaan käydyn sodan yhteydessä linnaleirijärjestelmä muuttui talonpojille määrättyjen ylimääräisten sota-apuverojen myötä varsinaiseksi sotaväen elatusvelvollisuudeksi.

Vuonna 1912 Suomen kuuluessa vielä Venäjän keisarikuntaan sai kantaesityksensä V.A. Koskenniemen sanoittama ja Toivo Kuulan säveltämä "Nuijamiesten marssi”. Sen uhmakkaat sanat viittaavat nuijasodan kapinallisiin, mutta veroteema on esillä korkeintaan hyvin kätketysti.

Englannista tunnetaan kuninkaiden (Edward I, II ja III) veropolitiikkaa vastaan tehtyjä protestirunoja ja -lauluja jo 1300-luvulta. Niissä arvosteltiin verotuksen ankaruutta sekä eriarvoisuutta ja korruptoituneita veronkantajia. Itävallan talonpoikaiskapinassa 1620-luvulla oli kysymys mm. uskonnosta ja verotuksesta. Kapinan yhteydessä esitettiin myös veroprotestilauluja. Kun ranskalaiset vuonna 1630 kapinoivat uhkaavia veroja vastaan, he lauloivat "Lanturelu"-nimistä laulua, josta liike sai nimensä. Sveitsissä vuonna 1653 puhjenneen verokapinan yhteydessä tuli laulusta "Entlebucher Tellenlied", joka muistutti Wilhelm Tellistä, kapinallisten marssilaulu. 1760- ja 1770-luvuilla brittien siirtokunnissa Amerikassa esiintyi verokapinointia ja myös veroprotestilauluja. ${ }^{64}$

62 Nuijasodan syiden monista selityksistä ks. erityisesti vuonna 2002 julkaistu Katajala Suomalainen kapina - Talonpoikaislevottomuudet ja poliittinen kulttuuri Suomessa Ruotsin ajalla (n. 1150-1800).

63 Tarkemmin esim. Ylikangas Nuijasota (1977).

64 Vanhoista veroprotestilauluista Burg A World History of Tax Rebellions - An Encyclopedia of Tax Rebels, Revolts, and Riots from Antiquity to the Present (2004) s. 108-109, 193, 198, 219-220, 266. 
Verokiistoilla on ollut osuutensa USA:n itsenäistymiseen Britanniasta 1700-luvun lopussa. Saadakseen amerikkalaiset siirtokunnat tunnustamaan Britannian verotusoikeuden Britannia salli vain verollisen teen viennin Amerikkaan. Amerikkalaisten protestien ja boikotin vuoksi teelaivat joutuivat palaamaan lastiaan purkamatta takaisin - paitsi yksi laiva, joka jäi Bostonin satamaan odottamaan purkamista. Joulukuisena iltana vuonna 1773 laivaan hiipi 60 intiaaneiksi pukeutunutta bostonilaista. He heittivät teelaatikot mereen, eivätkä tullimiehet pystyneet sitä estämään. Britit pitivät Bostonin tapahtumia kapinana ja lähettivät vuonna 1775 sotaväkeä kukistamaan niskuroijat, mikä johti vuosien sotaan ja lopulta Yhdysvaltain itsenäisyysjulistukseen. ${ }^{65}$ Teeveroon liittyy The Sensational Alex Harvey Band-yhtyeen vuonna 1976 julkaistu "Boston Tea Party", jossa on mm. seuraava amerikkalaisten kahvinjuonnin suosiota selittävä kohta:

Redcoats in the village and there's fighting in the streets

The Indians and the mountain men, well they are talking when they meet The king has said he's gonna put a tax on tea

And that's the reason y'all Americans drink coffee.

"Marseljeesi" on Ranskan kansallislaulu, josta tuli kumouksellisten tunnus Ranskan vallankumouksessa. Sen sävelsi ja sanoitti Claude Joseph Rouget de Lisle vuonna $1792 .{ }^{66}$ Sitä lauloi Marseillesta saapunut tasavaltalaisten komppania marssiessaan Pariisiin; tästä nimi.

Marssista tuli suosittu vallankumous- ja vapauslaulu useiden liikkeiden piirissä. Tekstiä vain on muutettu kulloisiakin olosuhteita vastaavasti. Sanat ovat hyvin veriset; yhdessä tuntemattoman tekijän suomenkielisessä versiossa (www.antiwarsongs.org/canzone) kritiikin kohteena on myös ahkeran kansan verottaminen:

Ja saako raaka mahtivalta lakeja meille laatia, ja kansan työltä ahkeralta veroa miekoin vaatia.

65 Teekutsuliike on nykyisin yhdysvaltalainen konservatiivinen liike, joka haluaa supistaa julkista sektoria. Liikkeen nimessä "TEA" tulee sanoista Taxed Enough Already ja viittaa Bostonin teekutsuihin.

66 Ks. tarkemmin esim. Wikipedia Marseljeesi. 
Me alla nälkäruoskan painon vain ryömisimme raataen kuin orjat tyynnä kärsien tän nurjan poljennon ja vainon?

Aseisiin astukaa ja vasten sortajaa! Eespäin! Eespäin! Lyökäämme näin pois valta riistäjäin!

Marseljeesi oli vuonna 1917 lyhyen aikaa myös Venäjän kansallislauluna nimellä "Kirotkaamme vanha maailma". Lokakuun vallankumouksen jälkeen sen syrjäytti "Kansainvälinen", joka on työväenmarsseista kuuluisin. Kansainvälisen alkuperäiset sanat teki Eugène Pottier (1871) ja sävelmän Pierre Degeyter (1888). Suomeksi laulun käänsivät sosialistit Otto Wille Kuusinen, Yrjö Sirola ja Sulo Wuolijoki (1905). Verotuksen osalta keskeinen on 3. säkeistö:

Lait pettää, hallitukset sortaa, verot köyhälistön verta juo, ja köyhän ihmisoikeuskin ompi tyhjä lause tuo.

Pois jo kansat holhouksen alta.

Veljeyden sääntö on:

kellä velvoitusta, sillä valtaa ja oikeutta olkohon.

Kaksi vuotta ennen tuon marssin suomeksi julkaisemista SDP:n Forssan kokouksessa (1903) oli hyväksytty seuraava veropoliittinen ohjelma:

"Kaikkien henkilöllisten ja välillisten verojen poistaminen yleisellä asteettain nousevalla tuloverolla, jolloin ansioton arvonnousu ja korkotulot sekä perintö on verotettava ankarammin kuin omasta ansiosta tai työstä johtuvat tulot. Verotettavan omaisuuden ilmoittamisvelvollisuus.”

Henkilöllisellä verolla tarkoitettiin varmaankin henkiveroa eli henkirahaa. Se oli tuohon aikaan kannettu könttäsummavero, joka kannettiin samansuuruisena jokaiselta tietyn ikäiseltä riippumatta tulon määrästä ja laadusta. 
Suomen ensimmäinen painettu työväenlaulujen kokoelma ilmestyi vuonna 1900 ja sisälsi yksitoista laulua. Siitä tehtiin myöhemmin laajennettuja uusia versioita. Sisällissodan aikoihin kehittyi runsaasti lisää työväenmusiikkia, ensimmäiseksi vankileirilauluja. Kommunistien laulut saivat paljon vaikutteita Neuvostoliitosta. 1960-luvun lopulla ja 1970-luvulla työväenlaulut olivat jälleen suosittuja nuorison vasemmistolaistumisen myötä. Suomalaisista työväenlauluista voidaan mainita seuraavat: ${ }^{67}$

"Balladi toveri Viljasesta", "Barrikadimarssi", "Kolme pikku miestä", "Kätten työtä," "Köyhälistön marssi”, "Laulu II maailmansodasta", "Laulu 20 perheestä", "Laulu punaisesta sydämestä", "Lenin-setä asuu Venäjällä", "Perustuslaillinen riemumarssi", "Punakaartin marssi", "Punaorvon vala", "Riistäjän lait", "Taistojen tiellä", "Tango fasismin ja kapitalismin suhteesta", "Työväen marssi", "Vapauden kaiho" ja "Veli, sisko".

Missään näistä lauluista ei mainita veroista. ${ }^{68}$ Verot eivät lienekään olleet Suomessa viimeisten vuosikymmenten aikana työväen suurimpia ongelmia.

Tietokirjailija Jukka K. Korpelan vuonna 2015 ilmestyneessä teoksessa "Suuri Huuhaakirja" kuitenkin todetaan veroista iloitsemisesta seuraavaa:

Amerikkalaisten tutkijoiden mukaan verojen maksaminen aktivoi aivoissa samoja "ilokeskuksia", kuten jotkin bilehuumeet. Oregonin yliopiston tiedemiesten mukaan verojen maksaminen tuo ihmiselle nautintoa, kertoo aikakauslehti Science. (Kauppalehti)

Tutkimusta on epäilty valtion rahoittamaksi, mutta todennäköisemmin asialla on ollut sosialidemokraattinen puolue. Muistammehan kaikki aito sosialidemokraattisen kehotuksen rakastaa veroja. Huuhaan Sosialidemokraattinen Puolue suosittaa, että opettelee rakastamaan erityisesti tietokoneveroa. Tähän ei sitten pidä kommentoida, että eihän sellaista veroa (vielä) ole - ettekö muka ole kuulleet romanttisesta, haaveilevasta,

67 Ks. Wikipedia Luettelo työväenlauluista.

68 Nimenomaista mainintaa veroista ei sisällä myöskään torpparien asemaan liittyvä Juho Kujalan voimakassanainen "Laulu Laukon häädöistä", joka ilmestyi alun perin vuonna 1908 kokoelmassa Hauskoja kuplettilauluja 2. Työvelvollisuus ja vuokranmaksu ovat kuitenkin verojen sukulaisia. 
jopa toivottomasta rakkaudesta? Lauloihan jo suuri sosialidemokraattinen ${ }^{69}$ bardi $^{70}$ Hiski Salomaa aikoinaan:

Oi verotus, kuule kutsua, sua itkevät orvot kaipaa.

Olet köyhän kansan pelastus, sulle vapauslaulumme raikaa.

Siteeratun teoksen esittelyteksti kuuluu seuraavasti:

Maailmassa on paljon huuhaata, jota esitetään ihan tosissaan ja asiana. Suuri Huuhaakirja sen sijaan keskittyy esittämään pelkkää huuhaata kieli poskella $^{71}$, erityisesti korostaen, että sitä ei pidä ottaa vakavasti.

Oikeasti Hiski Salomaan laulun toinen sana ei ollutkaan "verotus" vaan "vapaus".

\subsubsection{Pohjois-Amerikan 1900- ja 2000-lukujen verolauluja}

\subsubsection{Country ja rap}

Koska Yhdysvalloissa ja Kanadassa veroteema on ollut lauluissa esillä lähinnä county- ja rap-artistien kappaleissa, on syytä selvittää, mistä noissa tyylilajeissa on kysymys.

Countrymusiikki (suomessa myös kantri) on USA:n eteläosissa syntynyt musiikkityyli, jonka juuret ovat perinteisessä folkmusiikissa, black gospelissa ja bluesissa. Tyypillisiä soittimia ovat kitara, huuliharppu ja viulu. 1970-luvun lopulta alkaen suosioon ovat nousseet myös pop- ja rock-vaikutteita musiikissaan käyttävät countryartistit. Countryn juuret ovat Appalakkien alueella soitetuissa

69 Hiski Salomaata on pidetty sekä aatteellisesti vasemmistolaisena työväen miehenä että epäpoliittisena kuplettimaakarina. Hän oli syndikalistisen ammattiliiton jäsen ja kirjoitti työväenhenkisiä lauluja. Salomaa omaksui I maailmansodan sytyttyä republikaanisen vakaumuksen, koska republikaanit vastustivat sotaa.

70 Aikoinaan bardien tehtävänä oli lukutaidottoman väen keskuudessa säilyttää ja välittää entisaikojen sankariteoista kertovia tarinoita ja eeppisiä runoja sekä sepittää tilannerunoutta, kuten ylistyslauluja ja itkuvirsiä.

71 Tarkoittanee kieli poskessa. Ks. Kielikello 4/2011. 
eurooppalaisperäisissä viulusävelmissä. Englannista, Ranskasta ja Irlannista saapuneet uudisasukkaat toivat Amerikkaan omat kansanmusiikkiperinteensä, jotka yhdistyivät Amerikassa mm. afrikkalaisten orjien musiikkiperinteisiin. Radion tulon ja äänitysteknologian kehityksen myötä 1920-luvulla countrymuusikot pystyivät nauhoittamaan ja myymään musiikkiaan, ja tyylin suosio levisi koko maahan. Nimensä countrymusiikki kuitenkin sai vasta 1940 -luvulla. Tunnetuimpia countrymuusikkoja on ollut Johnny Cash. ${ }^{72}$

Rap on hiphop-musiikin alalaji, joka syntyi 1970-luvulla afroamerikkalaisten ja latinalaisamerikkalaisten keskuudessa. Hiphopille on tunnusomaista loppusoinnullinen ja rytminen puhelaulu eli räppäys (engl. rapping). Rapin katsotaan kehittyneen New Yorkin Bronxin puistoissa ja kaduilla järjestetyissä juhlissa, joissa esitettiin soulia, diskoa, funkia ja rockia.

\subsubsection{1900-luku}

Amerikkalainen countrylaulaja Dorsey M. Dixon levytti vuonna 1936 kappaleen "Sales Tax On The Woman", jonka The New Lost City Ramblers uudelleen esitti vuonna 1959. Laulun mukaan jauhot, rasva ja liha voidaan panna verolle, mutta naisista ja tytöistä ei silti saa (kulutus)veroa periä.

Lulu Belle ${ }^{73}$ ja Scotty olivat amerikkalainen pariskunta, jonka countrylaulut olivat USA:ssa suosittuja 1930-luvulta aina 1950-luvulle. He levyttivät vuonna 1952 kappaleen "I'm No Communist", jossa kritisoitiin myös hallituksen rahankäyttöä, lisääntyvää velkaa ja korkeita veroja:

The taxes keep on going up, of that there is no doubt But still, they just can't take it in as fast as they dish it out Our national debt is a monster size and growin' every day Our children's children, still unborn are gonna have to pay.

72 Suomalaisista muusikoista countrya ovat levyttäneet mm. Mikko Alatalo ja Jussi Raittinen.

73 Lulu Belle (oikealta nimeltään Myrtle Cooper) toimi myöhemmin poliitikkona (demokraatti). 
Vuonna 1963 Billy Edd Wheeler levytti Jerry Leiberin sanoittaman countrytyylisen "After Taxes", joka on tullut paremmin tunnetuksi Johnny Cashin vuonna 1978 esittämänä. Siinä kerrotaan miehestä, joka pettyy palkkapussiinsa. Liittovaltion, osavaltion ja kunnan verojen jälkeen hän joutuu luopumaan mm. matka- ja autohaaveistaan.

Vuonna 1974 julkaistiin Fred Wesleyn ja James Brownin "I'm paying taxes but what am I buying?", jossa toistetaan tuota kysymystä.

Vuonna 1977 Nina Hendryx, joka on Jimi Hendrixin etäsukulainen, esitti kappaleen "Tax Exile". Samannimisen rock-kappaleen on samana vuonna levyttänyt myös F.U.2-02. Edellisenä vuonna sveitsiläinen rock-yhtye TEA oli julkaissut samannimisen albumin. Tax Exile -nimisen kappaleen on levyttänyt myös Pink Floyd (2010). Tax Exiles puolestaan on brittiläinen artisti.

George Jones (1931-2013) oli erittäin suosittu yhdysvaltalainen countrymuusikko. ${ }^{74}$ Vuonna 1983 , jolloin hän näytti päässeen alkoholiongelmastaan, hän julkaisi kappaleen "Ol' George Stopped Drinkin' Today". Siinä laulettiin mm. seuraavasti:

Ol' George stopped drinkin' today

They're all gonna gather round me

Lord, I wish they could hear me say

No more income taxes

No more bills to pay

Ol' George stopped drinkin' today.

Countrytyylinen on myös "Leon McDuff", jonka The Nitty Gritty Dirt Band levytti vuonna 1985. Laulussa kerrotaan Leon-nimisestä miehestä, joka oli koko ikänsä työskennellyt isänsä maatilalla. Maatila kärsi tulvien, kuivuuden yms. vuoksi niin suuria vahinkoja, että sen veroa (land tax) ei ollut varaa maksaa. Kun sheriffi tuli ulosmittaamaan maatilaa, Leonin ase laukesi, sheriffi kuoli ja Leon joutui surmasta epäiltynä tuomioistuimeen.

Anthrax on suosittu yhdysvaltalainen trash metal / speed metal -yhtye. Se julkaisi vuonna 1988 kappaleen "Make Me Laugh". Laulussa esiintyvät Jumala, Jeesus ja evankelista. Veroista todetaan jotenkin

74 Tarkemmin esim. Wikipedia George Jones. 
arvoituksellisesti: "God say's taxes are a sin" ja "God say's file taxes lets".

Robert Cray on yhdysvaltalainen blueskitaristi ja laulaja, joka on esiintynyt muutaman kerran Suomessakin. Vuonna 1993 häneltä ilmestyi kappale "1040 Blues", jonka sanoissa vihataan kaiken vieviä veroja: "Don't you know I pay a lot more than my share."

\subsubsection{2000-luku}

2000-luvun verolaulut ovat olleet pitkälti rap-tyylisiä. Vuonna 2000 Kottonmouth Kings julkaisi rap-kappaleen "The Lottery", jossa arvostellaan verojen ankaruutta. Laulussa toistuu "Taxes stealin' but they got you trained". Vaikka kappaleessa on hyvin paljon sanoja (muitakin kuin fuck), sen sanoma jää epäselväksi. Laulussa kerrotaan mm. arpajaisvoitosta, joka mahdollistaa ylellisen elämän ( $\mathrm{mm}$. oma järvi ja eri talo joka päivälle).

Hiphoppari J-Zone (oik. Jay Mumford) julkaisi vuonna 2001 albumin "Pimps Don't Pay Taxes" (parittajat eivät maksa veroja). Albumissa on yhdeksän raitaa, joiden nimet eivät ainakaan viittaa veroihin.

Vuonna 2003 The Knife julkaisi kappaleen "You Make Me Like Charity". Koska siinä toistuu seuraava sanoma, esityksessä korostettaneen hyväntekeväisyyttä enemmän kuin verojen maksamista:

Instead of paying enough taxes

I took a cab there to hold her

I took a plane there to feel what she felt

You make me like charity

Instead of paying enough taxes.

Vuonna 2006 rap-artisti Terrell Brown levytti kappaleen "The Prayer", jossa mainitaan Jumalakin ja toistetaan sanoja "U take them taxes I get fucked".

Vuonna 2009 julkaistiin Fog of War -yhtyeen ensilevy "Death Penalty”. Tässä kuolemanrangaistusta käsittelevässä kappaleessa mainittiin myös veroista: ${ }^{75}$

75 Tarkemmin Tainan gradu Keywords in heavy metal lyrics (s. 19), Helsingin yliopisto 2014. 
A moment of silence, you hear not a sound

Fear chokes your soul as the gavel comes crashing down

The prisons are crowded, not an empty cell left

No tax payer dollars, you have been sentenced to death

No retribution, only electricution

Dead man walking, just one more execution!

Vuonna 2010 Pennsylvanian Luzernessa päätettiin korottaa paikallisveroa 10 \%:lla. Jotta asukkaat eivät maksaisi veroa, Fred Heller levytti laulun "Take This Tax and Shove It", jonka sanoitus oli seuraavanlainen: ${ }^{76}$

Take this tax and shove it ${ }^{77}$

We ain't paying you crooks no more

The good ol' boys stole all our cash

And ran out the courthouse door.

Kappale muokattiin vanhasta countryesityksestä "Take This Job And Shove It", joka alkoi näin:

Take this job and shove it

I ain't working here no more

My woman done left and took all the reasons

I was working for

You better not try to stand in my way

When I'm walkin' out the door.

B.o. $B^{78}$ (oik. Bobby Ray Simmons Jr.) on suosittu yhdysvaltalainen rapmuusikko. Hän on salaliittoteoreetikko, joka mm. väittää maapallon olevan litteä. B.o.B on käsitellyt lauluissaan useita yhteiskunnallisia ja poliittisia kysymyksiä. Vuonna 2016 häneltä ilmestyi "Blank Mafia”, jossa on paljon alatyylisiä sanoja, siis mm. fuck ja shit, sekä nimiä, mm. God, Martin Luther ja Morgan Freeman. Veroista todetaan arvoituksellisesti: "Boycotting taxes, that's dangerous thinking."

\footnotetext{
76 Wikipedia: Tax resistance in the United States.

77 "Shove it" on slangissa "pidä hyvänäsi”. Usein käytetään myös voimakkaampaa ilmausta "show it up your ass".

78 Lyhenne sanoista Bombs over Baghdad.
} 
Kuoleman ja verojen suhteesta muistutetaan useissa lauluissa. Vuonna 2012 kanadalainen rock-yhtye The Stanfields julkaisi albumin "Death \& Taxes", jolla ei kuitenkaan ollut nimenomaista mainintaa veroista. Kanadalainen laulaja ja sanoittaja Daniel Caesar (oik. Ashton Dumar Norwill Simmonds) julkaisi vuonna 2015 kappaleen nimeltä "Death \& Taxes". Siinä on vaikutteita mm. gospelista., ja sanoissa todetaan mm., että "It's funny how heaven and hell are the same" ja että elämässä varmaa on vain kuolema ja verot.

Vuonna 2018 julkaistussa The Recalculatingin rap-kappaleessa "Get Drunk and Do Your Taxes" mainitaan monia verovähennyksiä, jotka jäävät saamatta (mm. lapsivähennys ja hybridiautovähennys). Laulu päättyy seuraavasti:

Death and taxes - - Benjamin Franklin understood taxes

Death and taxes - - But Franklin never did taxes

Get drunk and do your taxes.

Hiphop-yhtye WSHH Heatseekers julkaisi vuonna 2018 levyn "Noobie Taxes", jossa hoetaan toistakymmentä kertaa: "I'm Michal Jackson and I never pay my taxes." Tuona samana vuonna Monty O'blivion esitti kappaleen "Western World", jossa mainitaan myös verojen maksaminen ("pay taxes, not attention"). Laulussa voidaan havaita kritiikkiä länsimaita kohtaan ("The free market is more sacred than your petty human rights").

Dr. Barzin vuonna 2019 julkaistussa rap-kappaleessa "Taxes" toistuvat jälleen mm. sanat fake ja fucking. Sanomana lienee mm. poliitikkojen ja verojen kritisointi. Samana vuonna ilmestyneessä yhdysvaltalaisen rap-artistin 2 Chaizin (oik. Tauheed Epps) kappaleessa "Sam" suhtaudutaan veroihin ymmärtäväisemmin; sen sanoissa todetaan mm.:

A tax is a mandatory financial charge

Imposed upon a taxpayer by a governmental organization

In order to fund various public expenditures

A failure to pay, along with evasion

Or resistance to taxation

Is punishable by law. 
Vuonna 2019 julkaistiin myös P-Funk Northin kappale "Flow So Sick", jossa on ymmärrettävääkin sanomaa. Laulussa todetaan mm.:

We live and learn

And love and burn

And smile and cry

Pay taxes then die

This is what we live for

These are the rules that we live by.

Vuonna 2019 ilmestyi myös Verhoogin hidas kappale "Misty", jossa toistuu "She was hummin' Death and Taxes". Sitä ei pidä sekoittaa Ella Fitzgeraldin ja monen muun paljon vanhempaan tunnelmalliseen "Mistyyn", jossa todellakaan ei käsitellä verotusta.

Vuonna 2020 Chaos New Money julkaisi monotonisen levyn "(Let Me Flip Your) Taxes". Laulussa mainitaan mm. Ms Jackson. Sanoituksessa esiintyy tiuhaan myös sana fuck ja toistakymmentä kertaa "Flip yo TAXES", mutta sanoma ei silti kirkastu. Samana vuonna The Beef Boys esitti verovastaisen rap-kappaleen "I Committed Tax Fraud". Laulussa haistatettiin $(f u c k) \mathrm{mm}$. USA:n verohallinto ja verotus sekä todettiin, että "Tax evasion make me brave".

Samoin 2019/2020 ilmestyi Rebel G:n vaikeatajuinen rap "Syntax", jossa todetaan mm.:

Sinning on your taxes, spinning off the waxes

Puff puff pass, there's an order to this madness.

Vuonna 2020 julkaistussa Døt Kb:n rapissa "Kingpin” puolestaan toistuu seuraava:

Bentleys, rollies, baddies, flexing Keep you guessing, gassing, masking

Passing something, never asking

Raising taxes, run the masses.

Vielä on syytä mainita The Granite Countertopsin "Get Out!", jossa todetaan veroista ja yhteiskunnallisesta vaikuttamisesta $\mathrm{mm}$. seuraavaa: 
I wanna go, I wanna go, I wanna see

I am paying the taxes for he

And he and he and she

Government doesn't do anything unless you tell it do

And if it doesn't have enough money to operate, no matter what you say, they cannot do it.

\subsubsection{Brittiläisiä verolauluja 1960- ja 1980-luvulta}

\subsubsection{The Kinks}

The Kinks oli 1960-luvun alussa Lontoossa perustettu rockyhtye. Sen tunnetuimpia kappaleita oli vuonna 1966 julkaistu maailmanmenestys "Sunny Afternoon", johon Ray Davies kirjoitti sanat:

The tax man's taken all my dough

And left me in my stately home

Lazing on a sunny afternoon

And I can't sail my yacht

He's taken everything I got

All I've got's this sunny afternoon

Save me, save me, save me from this squeeze

I gotta big fat mama trying to break me

And I love to live so pleasantly

Live this life of luxury

Lazing on a sunny afternoon

In the summertime

In the summertime

In the summertime

My girlfriend's run off with my car

And gone back to her ma and pa

Telling tails of drunkenness and cruelty

Now I'm sitting here

Sipping at my ice cold beer.

Suomeksi kappaleen levytti ensimmäisenä Johnny Liebkind nimellä "Iltapäivää". Pertti Reposen suomenkielisessä sanoituksessa on mm. seuraavat kohdat: 
Kun verot veivät rahani

Niin vanhan laiskanlinnani

Siirsin iltapäivän aurinkoon

Nyt siellä istun vain

Ja pääsen eroon murheistain

Jääden iltapäivän aurinkoon

Työhön, työhön,

Työhön ahkeraan

Nuo kaikki vanhat tädit

Tahtoo painostaa

Mutta, on niin kovin mukavaa

Aina kun mua laiskottaa

Jädä iltapäivän aurinkoon

Kun lämmin on

Kun lämmin on

Kun lämmin on

Vei tyttö uuden autoni

Sen metsään ajoi romuksi

Kertoi vielä minun käskeneen

Nyt mä linnassain

Istun tuoppi polvellain

Jääden iltapäivän aurinkoon

Työtä, työtä, työtä vastustan

On mulla hyvät syyt

Nyt minuun uskokaa

Koska on niin kovin mukavaa

Aina kun mua laiskottaa

Jäädä iltapäivän aurinkoon.

Kinksin kappaleen sanotaan sisältävän ironiaa ja piikittelyä Britannian verojärjestelmää, luokkayhteiskuntaa ja kapitalismia kohtaan. Britannian pääministeri Harold Wilson (työväenpuolue) oli ilmoittanut keväällä 1966 maan talouden heikentyneen niin, että oli turvauduttava veronkorotuksiin. Tästä Ray Davies lienee saanut idean kirjoittaa yläluokkaa satirisoivat sanat. ${ }^{79}$ Kappaleen voi toisaalta tulkita kertovan vain rennon kesäpäivän viettämisestä. Kun Robin levytti kappaleen nimellä "Iltapäivän aurinko", sen sanoituksessa, jonka oli tehnyt Tuula Valkama, ei mainittu mitään veroista - ylellisyydestä kylläkin.

79 Laulun synnystä ks. Wikipedia Aurinkoinen iltapäivä ja Sunny Afternoon. 


\subsubsection{The Beatles}

Vuonna 1966 julkaistiin myös The Beatlesin albumi "Revolver", jolla ensimmäisenä oli "Taxman". Kritiikin kohde oli selvästi suunnattu pääministeri Harold Wilsonin ajamiin veronkorotuksiin ja ennen kaikkea ankaraan progressioon tuloverotuksessa:

One, two, three, four, one, two

Let me tell you how it will be

There's one for you, nineteen for me

'Cause I'm the taxman, yeah, I'm the taxman

Should five per cent appear too small

Be thankful I don't take it all

'Cause I'm the taxman, yeah, I'm the taxman

If you drive a car, I'll tax the street

If you try to sit, I'll tax your seat

If you get too cold, I'll tax the heat

If you take a walk, I'll tax your feet

'Cause I'm the taxman, yeah, I'm the taxman

Don't ask me what I want it for

(Ah ah, Mr. Wilson)

If you don't want to pay some more

(Ah...

Laulun sanoitti ja sävelmän teki George Harrison. ${ }^{80}$ Hän sai tähän inspiraatiota ihailemansa 1960-luvun Batman-televisiosarjan tunnusmusiikista. Laulun sanoissa verottaja toteaa verovelvolliselle kuuluvan 1/20 eli $5 \%$ ja verottajalle 19/20 eli $95 \%$ ja kehottaa verovelvollista olemaan tyytyväinen, kun verottaja ei vie aivan kaikkea. Teema oli siis sama, jota Astrid Lindgren käsitteli kymmenkunta vuotta myöhemmin "Pomperipossa"-sadussa.

Tätä The Beatlesin kappaletta ei liene esitetty suomeksi (eikä ruotsiksi). Se on kuitenkin Suomen vero-oikeustieteessä huomioitu Reijo Knuutisen kirjassa "Hyvät pahat verot" (2017) s. 7-8, jossa teosta luonnehditaan verotustraumojen purkamiseksi sivistyneenä piikittelynä.

80 Kappaleen pohjalta on Junior Parker vuonna 1970 julkaissut blues-tyyppisen sovituksen. Sen sijaan Damon Fowlerin vuonna 2021 samalla nimellä julkaistussa bluesissa ei ole yhteyttä Beatlesin kappaleeseen; Fowlerin kappaleessa verovelvollinen ei avaa koputtajalle ovea. 


\subsubsection{Billy Bragg}

Billy Bragg (Stephen William Bragg) on vuonna 1957 syntynyt englantilainen protestilaulujen esittäjä-sanoittaja ja vasemmistoaktivisti. ${ }^{81}$ Hänen tyylissään on elementtejä folk- ja punk rock -musiikista. Vuonna 1986 häneltä ilmestyi menestysalbumi "Talking with the Taxman About Poetry", joka nimi oli otettu venäläisen vallankumousrunoilijan Vladimir Majakovskin ${ }^{82}$ runosta. Albumissa on toistakymmentä kappaletta, mutta ainoastaan yhdestä löytyy nimenomainen maininta veroista. Tuo kappale on "Ideology", ja sen kolmas säkeistö kuuluu seuraavasti:

Outside the patient millions

Who put them into power

Expect a little more back for theis taxes

Like school books, beds in hospitals

And peace in our bloody time

All they get is old men grinding axes.

\subsubsection{Suomalaisia verolauluja}

\subsubsection{Kansanlauluista}

Kansanmusiikki on kansanomaista musiikkia, joka on säilynyt muistin varassa. Kansanlaulujen tekijänoikeuksien haltijoita ei tunneta. Veroaiheisten kansanlaulujen löytäminen on osoittautunut vaikeaksi. Mainittakoon netistäkin löytyvä 12-säkeistöinen "Matin muijan kuolema", jonka voidaan ymmärtää kritisoivan kirkon ahneutta kirkon kymmenysten eli verojen kantamisessa. ${ }^{83}$

\footnotetext{
81 Wikipedia Billy Bragg.

82 Majakovski oli venäläinen ja neuvostoliittolainen vallankumousrunoilija.

83 Laulu on netissä ainakin J. Karjalaisen ja Veli-Matti Järvenpään esittämänä.
} 


\subsubsection{Protestilaulujemme teemoista}

Mika Kauhanen valitsi vuonna 2015 suomalaisten protestilaulujen 15 valiota. ${ }^{84}$ Niiden esittäjät, kappaleiden nimet ja protestin kohde olivat seuraavat (yle.fi/musiikki): ${ }^{85}$

Paleface: "Helsinki - Shangri-La" (2010), hyvinvointivaltion tila, vaihtoehtokulttuurin vaino, kulutusjuhla

Jukka Takalo: "Jokainen on vähän homo" (2010), homofobia

Asa: 'Loppuasukas" (2008), ympäristön saastuttaminen, ökyilevä elämä, valvontayhteiskunta

Soul Captain Band: "Älä juo tota juttuu" (2001), alkoholismi

Ultra Bra: "Ampukaa komissaarit, nuo hullut koirat!" (1995), Euroopan unioni, pääoman valta

Ismo Alanko: 'Kun Suomi putos puusta" (1990), maaseudun rakennemuutos, perinteiden hylkääminen, globalisaatio

Juha Vainio: 'Vanhoja poikia viiksekkäitä” (1982), saimaannorpan uhanalaisuus

Eppu Normaali: "Puhtoinen lähiöni" (1980), asuntopolitiikka

Veikko Lavi: 'Pienyrittäjän puolesta" (1980), pienyrittäjän heikko asema Agit Prop: 'United Fruit' (1972), ylikansalliset yhtiöt kehitysmaissa

Irwin: 'Ryysyranta" (1967), kotimaan kurjuus

Simo Salminen: "Rotestilaulu" (1966), protestilaulut

Jukka Kuoppamäki: "Alaikäinen" (1966), nuorison sortaminen säännöillä

M. A. Numminen: 'Naiseni kanssa eduskuntatalon puistossa' (1966), tekopyhät normit

Hector: 'Palkkasoturi" (1965), sota.

84 Iskelmäradio-ohjelmassa Tarja Närhi "Kun kukaan ei tee millekään mittään politiikka laulujen aiheena" (2017, uusinta Radio Suomi 13.6.2021) esitettiin 13 laulua, joista veronmaksu mainittiin vain yhdessä ja siinäkin ohimennen.

85 Monista ajankohtaisista teemoista vanhoilla sävelmillä mutta uusilla sanoilla on laulanut hupaduuri Ilkka Aaltonen. Tällaisia esityksiä ovat mm. ”Diktaattorien kiekkokuume", "Valmiuslaki”, "Varsinaiset virusmatkat", "On meillä kaarre verraton", "Pois on Donald", "Reittilento Liettuaan" ja "COVID”. Näitä mainioita esityksiä ei pidettäne varsinaisina protestilauluina. Aaltosen ja hänen yhtyeensä (Hummeripojat) monipuolisuutta kuvaa sekin, että he ilmoittavat tilauksesta tekevänsä laulun aiheesta kuin aiheesta. Veroteemaan liittyviä heiltä ei liene vielä tilattu. 
Suomalaisten protestilaulujen teemat ovat usein samoja kuin vaikkapa Britanniassa ja USA:ssa. ${ }^{86}$ Protestien kohteena ovat yleensä verotustakin suuremmat kysymykset, esimerkiksi sota, ${ }^{87}$ köyhyys, eriarvoisuus ja ympäristöongelmat. Seuraavassa keskitytään sellaisiin lauluihin, joissa verotuksella on jonkinasteinen rooli. Monesti niissä kerrotaan muistakin yhteiskunnan tai yksilöiden ongelmista.

\subsubsection{Eino Virtanen ja Lasse Kuusela}

Eino Virtanen (1925-1999) oli laulaja, säveltäjä, kapellimestari, sovittaja ja trumpetisti. Häneltä ilmestyi vuonna 1965 Pertti Reposen sanoittama "Verotus on kauhistus". Se kertoo alistuvaan sävyyn miehestä, jonka tilipussi oli veroennakon pidättämisen jälkeen melkein tyhjä, minkä vuoksi miehen oli turvauduttava panttilainaamoon. Hän ei voinut myöskään toteuttaa esimerkiksi matkustushaaveitaan, ja hiljaa hän luisui turmioon.

Vuonna 1975 Lasse Kuusela lauloi kappaleen ”Verovalitus". Siinä ei kerrottu, miten verovalitus oikeaoppisesti tehdään, vaan kysymyksessä oli yleisluonteista verokritiikkiä sisältänyt melko leppoisa kappale, jossa korostettiin verokohteiden laajuutta ja vihjailtiin karhujahdista, koska lainsäädännön porsaanreikien vuoksi verorasitus oli duunareilla.

\subsubsection{Irwin Goodman}

Antti Hammarberg (1943-1991), paremmin tunnettu nimellä Irwin Goodman, oli Hämeenlinnassa syntynyt ja nuoruutensa viettänyt

86 Ks. esim. Marcaton Venetsian yliopistossa lukuvuonna 2012/2013 tekemä tutkimus A sociological approach to The Beatles' protest songs, jossa on selvitetty protestilauluja myös Irlannissa, Etelä-Afrikassa, Jamaikalla ja Portugalissa.

87 Koska veroja on käytetty myös sotien rahoittamiseen, militarismia on vastustettu paitsi aseista myös veroista kieltäytymällä. Esimerkiksi amerikkalainen laulaja ja lauluntekijä Joan Baez ilmoitti jättävänsä vuoden 1963 veroistaan 60 \% maksamatta protestina Vietnamin sodalle (Wikipedia Joan Baez). 1960-luvun lopulla sadat kirjailijat ja toimittajat laittoivat New Yorkin lehtiin ilmoituksen aikovansa kieltäytyä maksamasta Vietnamin sodan rahoittamiseksi perittävää lisäveroa. Myöhemminkään tällaiset protestit eivät ole olleet tuntemattomia. Esimerkiksi vuonna 2011 yhdysvaltalainen kirjailija Shane Caiborne ilmoitti verohallinnolle jättävänsä tuloverostaan maksamatta sen osuuden, joka vastasi valtion budjetin sotilasmenoja, ja antavansa sen hyväntekeväisyyteen. 
laulaja ja säveltäjä. ${ }^{88}$ Hänen yhteistyökumppaninsa oli sanoittaja Vexi Salmi. Goodmanin tuotannossa merkittävä osa on protestilauluilla, joiden teemoja olivat mm. kansan olojen ja tuntojen kuvaaminen, alkoholi, rahatalous sekä ulosotto- ja muiden virkamiesten, poliitikkojen ja varsinkin verotuksen arvostelu. Pontimena verokritiikille olivat erityisesti hänen omat vero-ongelmansa, jotka johtivat $\mathrm{mm}$. hänen asuntonsa pakkomyyntiin. Mielenkiintoista on, että Salmi kertoi pitävänsä verojen maksamista kansalaisvelvollisuutena ja verotuksen porsaanreikien etsijöitä rintamakarkureina; kokonaisuutena pohjoismainen verotustapa oli Salmen mielestä aika oikeudenmukainen. ${ }^{89}$

Jo vuonna 1966 ilmestyneessä "Uusi Paavo" -kappaleessa verotuksella oli roolinsa, kun laulun sanoissa todettiin:

Halla jälleen putsaa sarat.

Mutta laki turvaa varat.

Arvon mekin ansaitsemme Suomen maassa suuressa.

Tulot kasvaa kyntäjälle, verot työnsä täyttäjälle.

Työttömyyttä, rahojen puutetta ja verotusta käsiteltiin myös kappaleessa "Kun ei rahat riitä" (1968):

Eduskunnan neuvo on: "Rukoile ja kiitä."

Eihän se nyt pelkästään kai elatukseen riitä?

Työttömyyden ehkäisy näin sujuvasti toimii.

Osa kansaa metsikössä puolukoita poimii.

Tilipussin täyttää kohta pelkkä veronauha.

Tarpeeton on monellekin nyt jo soppakauha.

Vuonna 1969 julkaistussa kappaleessa "Karhutaan" ollaan ulosmittaamassa verovelkoja. Tässä laulussa on $\mathrm{mm}$. seuraavat kohdat:

Vapaana on karhu, joka riehuu kaikkialla.

Monen torpan ovella se nytkin karjahtaa.

Karhu tää ei nuku edes koskaan talviunta. satoi taikka paistoi, niin se oveen kolkuttaa.

Omiansa vaatii jälleen valtio ja kunta.

Pennit jonoon, heti verorästit maksakaa!

88 Tarkemmin esim. Wikipedia Irwin Goodman.

89 Ks. tarkemmin esim. Wikipedia Vexi Salmi. 
Vuonna 1969 ilmestyi "Meni rahahommat pieleen”, jossa on verokritiikin lisäksi itsekritiikkiäkin:

Taisi hommat nää nousta mulle nuppiin.

Tehtiin tuolitkin minkistä vaan.

Kauniit cocktailit sekoittelin kuppiin.

Olin mahtavin päällä mä maan.

Kun on jätkä, niin jätkäksi myös jääkin.

Verot fyrkkani kerralla vei.

Netissä on tästä kappaleesta myös Maustetyttöjen hieno esitys, joka on julkaistu koronarajoitusten aikana vuonna 2021. Laulun sanat poikkeavat Irwinin esityksestä vain siten, että Maustetytöt eivät syytä veroja. Kohta "Verot fyrkkani kerralla vei” nimittäin on korvattu sanoilla "Sanna keikkamme kerralla vei"90, jolla epäilemättä viitattiin pääministeri Sanna Marinin hallituksen toteuttamiin kulttuuritapahtumien koronarajoituksiin.

Voimakkainta Irwinin verokritiikki on vuonna 1976 kappaleessa "Haistakaa paska koko valtiovalta", jonka toisessa sanassa s-kirjaimen voimakas ääntämys varmaan havainnollistaa esittäjän tunnelatausta:

Haistakaa paska koko valtiovalta.

Ette osaa muuta kuin verottaa.

Muutenkin touhu tuntuu holtittomalta.

Kaikki pitäis kerralla erottaa.

On siinä meillä omituinen sakki.

Kaikki sitä johtohommiin pääseekin.

On nyt jo tyhjä joka jätkän takki.

Mutta verotus vain jatkuu hurjemmin.

On aivan turhaa enää tehdä työtä.

Verot vievät koko palkan kuitenkin.

Saat viettää monta unetonta yötä.

Herrat teki elämästä helvetin.

90 Englanninkielisessä Maustetyttöjen versiossa ei mainita Sannaa, vaan tämä kohta kuuluu: "Suddenly they took all our gigs away." 
Ja kun on verorahat kaikki juotu.

Kansa kyllä pikku vipin järjestää.

Vain päätös niin on lisävero luotu.

Sillä lailla kassahuolet selviää.

Myöhemmin Irwiniltä ilmestyi1 vielä "Verottaja ja vouti” (1983). Siinä oli mukana sotilasmarssinakin tunnettua laulua "Eikä me olla veljeksiä”. Irwinin kappaleen sanat, jotka kirjoitti Tapani Koivisto, ovat arvoitukselliset. Uskottavalta tuntuu tekijänoikeuksien ja verotuksen asiantuntijan JV:n seuraava analyysi:

Laulussa "Verottaja ja vouti" on kyse verohallinnon (verottaja) ja ulosottoviranomaisen (vouti) väitetystä yhteistyöstä ja samalla puolella olemisesta. Laulun sanoman mukaan molempien tavoitteena on saada mahdollisimman paljon rahaa valtiolle välittämättä sen seurauksista verovelvollisille. Siispä laulussa verottaja verottaa kaiken ja vouti auttaa verottajaa ulosmittaamalla kaikki verovelvollisten varat ja tulot.

Laulussa mukaillaan marssia "Eikä me olla veljeksiä", jossa viitataan armeijan taistelupariin, joka tukee toisiaan taistelussa. Irwinin laulussa vero- ja ulosottoviranomainen väittävät olevansa erillisiä ja itsenäisiä hallinnon toimijoita, mutta toimivat kuitenkin yhteistyössä ja edustavat samaa yhtenäistä hallintoa kuin marssin yhteen toimiva taistelupari tai veljekset. Vastapuolella ovat verovelvolliset, jotka menettävät "rahat valtiolle". Laulu esittää siten rankkaa kritiikkiä verohallinnon ja ulosottoviranomaisen objektiivisesta toiminnasta ja viranomaisten keskinäisestä erillisyydestä.

Laulu koostuu "marssiosista" ja "tarinaosista". Marssiosan alussa verottaja ja vouti toteavat marssin sanoin "Eikä me olla veljeksiä", mitä Irwin ihmettelee, koska hän on aina luullut niin (siis olettanut, että verottaja ja vouti ovat veljeksiä). Tarinaosassa kerrotaan verottajan verottavan kaiken mahdollisen, mutta kun "verot kasvaa, leipä loppuu, verottajan tulee voudin luokse hoppu". Verottaja hakee siis voudin apua verojen ulosottoon. Seuraavaksi marssiosassa verottaja ja vouti toteavat marssin sanoin olevansa mammanpoikia lahden toiselta puolen. Mihin Irwin toteaa, että mammanpoikia kyllä, mutta ei lahden toiselta puolen ainakaan. Sitten tarinaosassa kerrotaan, kuinka vouti auttaa verottajaa ("vouti apuun rientää") ja sen seurauksena kaikki ulosmitataan; "Rahaa valtiolle!”. Taistelupari voittaa, verovelvollinen häviää.

91 Esitys oli alun perin c-kasetilla "Uudet protestilaulut", jota valmistettiin parinsadan kappaleen erä ja myytiin joillakin huoltoasemilla. Kappale julkaistiin uudelleen vuonna 2015 albumilla "Irwin Goodman Ennenkuulumattomat - Lauluja suomalaisille". Ks. tarkemmin Mika Seppänen is.fi/musiikkiviihde 4.3.2015. 
Marssiosan lopussa verottaja ja vouti toteavat marssin sanoja mukaillen, että "viimeinkin ollaan veljeksiä, tältä puolen lahden". Eli verottaja ja vouti ovat sittenkin samalla puolella, yhteistyössä hankkimassa rahaa valtiolle. Lopuksi vielä rallatellaan marssin "jalajallai jalajala veiveivei"osuutta vastaavalla tavalla "Vero, vero, vero, vero, vero vei, vei, vei! Ja tältä puolen lahden”.

Irwinin laulussa mukailtu marssi "Eikä me olla veljeksiä" liittyy aikaan, jolloin Suomi oli osa Ruotsia ja suomalaiset suorittivat asepalveluksen Ruotsin armeijassa. Siksi marssissa puhutaan mm. lahdesta (siis ilmeisesti Pohjanlahdesta) ja "ruunun rossista rinnan päällä" (kruunun kunniamerkeistä rinnuksessa). Irwinin laulussa ei oteta kantaa Ruotsin verotukseen tai asepalvelukseen, vaan marssia on lainattu ja mukailtu tarkoituksena osoittaa verohallinnon ja ulosottoviranomaisen oletettu petollinen yhteistyö.

Irwinin esittämissä kappaleissa ei ole yleensä tarkasti eritelty verokysymyksiä - esimerkiksi sitä, oliko tuloverotaso liian korkea tai progressio kohtuuton, eikö verotus ottanut tarpeeksi huomioon tulomäärän vuosittaisia vaihteluita, olivatko ennakkoverot liian pieniä lopulliseen veroon nähden tai oliko veroilmoitusten teko liian vaikeaa. Irwinin omista vero-ongelmista on esitetty (irwingoodman.com) seuraavaa:

Periksiantamaton luonne tuli esille ja korostui erityisesti verottajan kanssa taistellessa. Se oli koko uran aikainen projekti, joka alkoi epäselvissä olosuhteissa joskus 1969, ja sen jälkeen arvioverotus sanktioineen jauhoi verovelat miljooniin markkoihin. Ensin meni auto, sitten irtaimisto, sen jälkeen talo. Rahaa oli tullut paljon, mutta sitä meni enemmän.

Sen jälkeen veroilmoitusta ei edes yritetty enää tehdä. Irwin olisi tarvinnut ehdottomasti taloudellisen neuvonantajan, tai edes kirjanpitäjän. Idearikkaat taiteilijat, Hammarberg ja Salmi, löysivät kyllä keinot tehdä omaa erityistä materiaaliaan, ja menestystä myös keikkamarkkinoilta, josta varsinaiset tulot siihenkin aikaan haettiin. Mutta talouden hallinta ja sen puolen realiteetit olisi pitänyt edes jotenkin kyetä ottaa huomioon. Niin ei vain käynyt, ja sekin kaikki on historiaa, vieläpä räiskyvää sellaista. 


\subsubsection{Mikko Alatalo}

Idea käsillä olevaan taideverokirjaan tuli Mikko Alatalon (s. 1951) vuonna 1978 julkaistusta kappaleesta "Yhdentoista virran maa". Alatalo myös oli keskustan kansanedustajana 2003-2019. ${ }^{92}$ Hän on kirjoittanut yli 600 musiikkikappaletta. Niistä yksi on tuo virtalaulu, jossa mainitaan ainaisesta verottajavihasta. Kappaletta pidetään yhtenä Alatalon pääteoksista, ja sen sanoissa todetaan mm.:

Se maa, jossa kasvoin, on lakien maa ja kunnioittaa kansa lain laatijaa.

Siellä on mielivaltaa, sortovaltaa, esivaltaa ja on myös tiedon valtaa kapinat kukistamaan.

Siellä maassa, jossa kasvoin, vanhaa kunnioitetaan ja jumalauta siellä ei pilkata Jumalaa.

Saat rammalle nauraa, mutta vanhalle ei. Ja nuoruus on hulluus, otsan uurteet vain sen vei.

Se maa, jossa kasvoin, se on miesten maa. Siellä miehet ei halata eikä suuvella saa.

Ja yhdyntä on vuoksi siittämisen ja nainen on vuoksi synnyttämisen.

Se maa, jossa kasvoin, on sankarien maa. Oli Vesaisen Juho, joka poltti Karjalaa.

Oli Nätti-Jussi ja oli myös Susi-Kalle ja oli kaikki ne nimettömät, jotka jäi anturan alle.

Se maa, jossa kasvoin, se on vihan maa. Siellä vihataan nälkää ja lakkoilijaa.

Siellä vihataan herraa, ei omistajaa, ei enää niin ryssää, aina verottajaa.

Tämä Alatalon runollinen kappale tuo mieleen mm. Isonvihan aikaan liittyvän Eino Leinon Hurtta-runon, jota on käsitelty edellä runouden yhteydessä.

Verotus mainitaan monessa muussakin Mikko Alatalon erityisesti yhdessä Harri Rinteen ${ }^{93}$ kanssa tekemässä laulussa. Kappaleessa ”Uusfasismia vastaan" (1978) mainitaan mm. hakaristit, SA, USA ja Vietnam, mutta on siinä verotuksellakin roolinsa:

92 Mikko Alatalosta on vuonna 2020 julkaistu erittäin perusteellinen Marjamäen laatima elämänkerta Hän hymyilee kuin Mikko. Kirjassa kerrotaan myös Alatalon vero-ongelmista 1990-luvun lama-aikana sekä Alatalon toiminnasta eduskunnassa mm. tekijänoikeuslainsäädäntöä käsiteltäessä.

93 Harri Rinne on kirjoittanut myös kirjoja, mm. Viron lähihistoriaa käsittelevän "Laulava vallankumous - Viron rocksukupolven ihme" (2007). 
Ennen tunsi fasistit jo koppalakeistansa nyt koppalakit mersuissa on kuljettajinansa vanhan ajan fasismi suosi leirielämää nyt ne postiluukuista leirin meille kotiin lähettää Piikkilangat vaihtui verokorkkiruuviin.

Kappaleessa "Jätkät senkun porskuttaa" (1979, johon on saattanut vaikuttaa Aleksis Kiven "Seitsemän veljestä", todetaan:

Kaikkivaltias on herra, kaukaa viisas hän antoi metsäpalon torppaa koetella pystyyn vain jäi kakluuni ja pirtin puuhella pojille tuo metsän herran verotus jo piisas Korpeen pisti pystyyn uutta torppaa nuo seitsemän potraa jätkää herrat tuli tiukkaamaan rakennuslupaa ja toiset herrat lisäverot mätkää.

Kappaleessa "Kun iso joki tulvii" (1981) verotus mainitaan perheen ja asunnon välissä seuraavasti:

Joka mielen täytti eilen vielä perhe, veronmaksut, asunto ja arkinen työ. Nyt ihmiset silmänsä sulkee ja uskoo: Tää on vain yö.

\footnotetext{
"Erottamattomat" (1983), jossa on veroteemaakin, päättyy seuraavasti:
}

Sillä elämä on lahjus, niin sanotaan ja ylikorot, uskonto ja isänmaa se on dynaamisen porvarin puhetta oltiin mistä puolueesta sitten tahansa Kyllä äänestäjiä nyt lapsettaa jos ne luulee jotain muuttavansa vaaleillaan kyllä vennamolaisetkin rauhottuu kun pääsee demareitten imuun juu Meitä ei kukaan voi enää verottaa mustat markkamme Sveitsissä on rötösherrana elo on niin mukavaa ja rietasrouvat on ihania. 
Vuonna 1984 julkaistussa kappaleessa "Artturi Robotti levitoi” avaruusaluksella tuodaan Maan pinnalle painoton tanssi. Laulussa on mukana verotuskin:

Oli aikuisten jalat lyijyä, lapset kelluivat kuin luonnostaan ja hallitus tietenkin totesi "tätäkin voi verottaa".

Kansainvälisen verovälttelyn mainitsee myös "Että hyvät voittaisi” (1990), jossa todetaan:

Jolla rahat on veroparatiisissa

hän kohta on median rakastama.

Laman aikana esitetyssä laulussa "Ihminen on selviytyjä" (1993) on seuraava verollinen kohta:

Mitä viroista ja veroista

ei todella mittaa ihmistä

kohtaamisista, eroista

koostuu ihmisen elämä.

Keskiluokan asemaa verotuksessa kuvaa "Tästäkö minä maksan” (1994):

Kun työnsä tekee, veronsa maksaa, mitä sillä saa isot herrat rahat vie ja pummit takseilla matkustaa

Tulonjakokysymykset ja verotuksen tuo vahvasti esiin "Isojako" (1994). Laulussa mm. todetaan: ${ }^{94}$

Isohan se jako on Suomessa, kyllä tämä poika makselee vientiteollisuus on kuin kirkko, se kymmenykset tarvitsee [- - ]

No köyhiltä on viety aina, nyt keskiluokkaakin rangaistaan siellä Euroopan ahneimman veronahkurin orsilla tavataan.

94 Laulun syntytaustasta Marjamäki Hän hymyilee kuin Mikko (2020) s. 355. 
Mikko Alatalon ja Harri Rinteen yhteistyötä on menestyskappale "Vicky Lee" (1978). Vaikka siinä ei puhuta veroista, senkin taustalla on verotus. Laulun idea kuulemma syntyi veroviraston Rinteelle lähettämästä kirjeestä. Kirjeessä väitettiin Rinteellä olevan Vicky Lee -niminen vaimo, tämän kanssa kaksi lasta ja verotkin rästissä. Aivan toisennimisen naisen kanssa naimisissa ollut Rinne kuuluu kirjoittaneen vastauskirjeeseensä: "Missä oot, Vicky Lee". ${ }^{95}$

\subsubsection{Juha Vainio}

Juha "Watt" Vainio (1938-1990) oli laulaja, säveltäjä ja sanoittaja. Hän teki noin 2500 sanoitusta tai sävellystä ja levytti itse noin 250 laulua. Vuonna 1977 Vainio esitti "Verolaulun", jonka sävel on samantapainen kuin tunnetussa kappaleessa "Sellanen ol' Viipuri". Verolaulun lopussa todetaan (ei lauleta): "Mitä enemmän verotus käy progressiivisemmaksi, sen aggressiivisemmaksi käy kansa."

Vuonna 1983 Vainiolta ilmestyi "Viiden vuoden päästä", joka liittyy ihmisten ja verojen vanhentumiseen. Verojen vanhentumisaikahan on viisi vuotta. Laulussa todetaan $\mathrm{mm}$.:

Mä lompakosta otan esiin kirjeen nuhruisen.

On siinä Kalle Liljeroosin viesti viimeinen.

Hän mulle tiedottaa:

On tosi ihanaa

näin matkalaukku rahaa täynnä kiertää maailmaa.

Kun vuosikymmen sitten häipyi maasta Liljeroos, niin poliisi ja verottaja kauan perään huus'.

Ja Kalle lähteissään vain kirjeen jätti tään, joka minut saa taas miettimään.

Hei, viiden vuoden päästä me jälleen tavataan, yhdeksältä siis kun Kuopan ovet avataan.

Hei, viiden vuoden päästä, kun verot vanhat on, kerron sulle hieman säästä Meksikon.

95 Marjamäki Hän hymyilee kuin Mikko (2020) s. 148. 
Niin vuodet vieri, Kuoppa vaihtoi tyylin hienompaan.

Mut' Kalle Liljeroos ei tullut vielä silloinkaan.

Ja joku kertoi näin,

tuo vanha ystäväin

on matkalaukun kanssa nähty Floridassa päin.

Mä riemastuin: "Pian rikas Kalle palaa takaisin."

Mut' kertoja joi tuopin, sitten virkkoi loputkin:

"Ei Kalle omista

ees' matkalaukkua,

se on asemalla kantaja."

\subsubsection{Sleepy Sleepers}

Vuonna 1974 perustettu Sleepy Sleepers on huumorirock-yhtye, joka on herättänyt huomiota $\mathrm{mm}$. provosoivilla sanoituksillaan. Yhtye on levyttänyt parhaimmillaan useita albumeja vuodessa. ${ }^{96}$ Vuonna 1984 ilmestyneen albumin "Sossu-Possuilua Finlandiassa - Totuus punataudista!" kansikuvassa sairasvuoteella makaavalle sanotaan: "No mutta ettehän te vielä voi kuolla. Teillähän on veroja rästissä." ”Verorockissa" luetellaan suuri määrä veroja, joista osa on yhä voimassa (mm. tulovero, perintövero ja autovero), osa on jo kumottu (mm. huvivero). Luetteloon sisältyy myös taiteilijan vapaudella keksittyjä (mm. jenkkavero, luonnonsuolivero ja munavero). Osaa laulussa mainituista veroista kutsutaan nykyisin toisilla nimillä - tänä päivänä puhutaan esimerkiksi ympäristöverosta eikä luonnonsuojeluverosta.

Saman yhtyeen saman vuoden albumiin "Suomen poliisit" sisältyy kappale "Verotoimiston huorat". Siinä sanoja on niukasti, lähinnä vain "Verotoimiston huorat - ne ei tajuu". Sanomaa on vaikea päätellä. Keitä ovat laulussa mainitut verotoimiston huorat, ja mitä he eivät tajua? Olisiko muusikoilla ollut verottajan eli verotoimiston virkailijoiden kanssa tulkintakiistoja siitä, ovatko tietyt menot verotuksessa vähennyskelpoisia tulonhankkimismenoja vai vähennyskelvottomia elantomenoja?

96 Yhtyeestä tarkemmin esim. Wikipedia Sleepy Sleepers. 
Wikisanakirjan mukaan "huora" on halventava ilmaus, jolla tarkoitetaan prostituoitua $^{97}$, avionrikkojaa ja seksuaalisesti aktiivista naista, mutta sitä voidaan käyttää yleisenä naisiin kohdistuvana haukkumasanana. ${ }^{98}$ Huoraamisella taas saatetaan viitata myös korruption tapaiseen toimintaan, jossa maksua tms. vastaan tehdään kiellettyjä asioita (esim. verotarkastaja ummistaa silmänsä).

\subsubsection{Klamydia ja Iglu}

Vuonna 1988 perustettu Klamydia ${ }^{99}$ on punk-yhtye, jonka kokoonpanossa on tapahtunut ajan mukana suuria muutoksia. ${ }^{100}$ Yhtyeellä on paljon humoristista tuotantoa, mutta sekaan mahtuu myös yhteiskunnallisesti kantaa ottavia ja vakavampia teemoja. Vuonna 1993 julkaistuun albumiin "Masturbaatio ilman käsiä” sisältyy "Veroparatiisi"-kappale, joka lienee protesti Suomen silloista talouslamaa kohtaan:

Hei lähe mukaan vaan.

Tonne kylmään pohjolaan.

Mä näytän sulle pienen maan.

Jossa oudolla tavalla irrotellaan.

Miltei nälkää näkevä.

Työtä tekevä.

On pihdeissä siellä pieni ihmiseläjä.

Tuu veroparatiisiin

Jossa kiskotaan!

Paratiisiin, jossa kusetetaan!

Paratiisiin, jossa hitaasti sut kuristetaan!

Tuu veroparatiisiin, jossa kiskotaan!

Paratiisiin, jossa kusetetaan!

Paratiisiin, jossa ei hanttiin panna ollenkaan!

Ja taas maksetaan!

97 Prostituutiosta ja sen verokohtelusta ks. esim. Linnakangas - Juanto, Synti- ja haittaverokirja (2020) s. 170 ss.

98 Vuonna 2020 Verohallinnon runsaasta 5000 työntekijästä $73 \%$ oli naisia.

99 Klamydia on myös yleinen bakteerin aiheuttama sukupuolitauti. Yhtyeen monet kappaleet liittyvätkin seksiin.

100 Tarkemmin esim. Wikipedia Klamydia (yhtye). 
Suomesta tuli vuoden 1995 alussa Euroopan unionin jäsen, ja siihen liittyen meillä säädettiin arvonlisäverolaki. Klamydia julkaisi noihin aikoihin albumin "Arvonlisäveron mekin ansaitsemme", jonka ensimmäinen kappale oli veroaiheinen "Suomi-neidon elätit".

Porilainen yhtye Iglu on äänittänyt kappaleen "Koiraverohelvetti", ${ }^{101}$ joka sisältyy myös vuonna 1997 julkaistuun albumiin "Cabaret Nocturno Vol II". Kuulijoille jää epäselväksi, miten kappale liittyy nimeensä, koska siinä ei ole sanoja eikä esimerkiksi koiran haukuntaa. Tyylilajina levyllä on lähinnä noise-musiikki, jota voidaan luonnehtia seuraavasti:

Noise on elektronisen musiikin alalaji, jonka juuret ovat konkreettisessa musiikissa ja industrialissa. Kappaleet ovat tyypillisesti erilaisista häiriöja kiertoäänistä koottuja kovaäänisiä kollaaseja, joissa selvillä taajuuksilla soivat sävelet ja niiden muodostamat melodiat ovat hyvin vähäisessä osassa tai puuttuvat kokonaan. Noisen alalajeja ovat mm. erityisen aggressiivinen ja kaoottinen harsh noise sekä rytmiikkaa ja rumpusampleja sisältävä power noise eli rhythmic noise. ${ }^{102}$

\subsubsection{Veikko Lavi (Pertti Koivula) sekä Heikki Kinnunen ja Satu Silvo}

Veikko Lavi (1912-1996) on julkaissut suuren määrän kantaa ottavia yhteiskunnallisia lauluja. Nimenomaisesti verokappaleita ei ole kuitenkaan hänen tuotannostaan löytynyt. Lavin kappaletta "Silakka-apajalla" mukaillen Pertti Koivula on kuitenkin vuonna 1995 Akkulaturit-ohjelmassa esittänyt kappaleen "Raskaasti verotettu laulu”, jossa luetellaan kymmeniä veroja.

"Lauluja verotuksesta" on Veronmaksajain Keskusliiton vuonna 1997 liiton 50-vuotisjuhlan kunniaksi julkaisema albumi, jolla on seitsemän kappaletta. Niistä "Veroblues" ja "Veroswing" ovat

101 Koiravero tuli ylellisyysverojärjestelmäämme vuonna 1800. Sitä maksettiin myös metsästyskoirista, mutta kahle- ja paimenkoirat olivat verovapaita. Ensimmäinen kunnallinen koiraveromme säädettiin vuonna 1878, ja se tapahtui erityisesti terveyspoliittisista syistä; vapaana kuljeksivat koirat levittivät vesikauhua. Vuodesta 1991 lukien kunnanvaltuusto sai päättää, suoritettiinko kunnassa koiraveroa. Veron pelasti kuolemalta sen näkeminen tietynlaisena päästö- ja jäteverona. Vähitellen koiravero kävi kuitenkin uhanalaiseksi, ja 2010-luvun lopulla se lopetettiin.

Wikipedia Noise. 
instrumentaaliesityksiä. Laulun "Olithan kerran minun" sanoissa ei mainita mitään veroista; sen sijaan tässä Kaj Chydeniuksen säveltämässä ja sanoittamassa kappaleessa puhutaan rakkaudesta niin kauniisti ja koskettavasti, että se sopisi hyvin esitettäväksi vaikkapa hautajaisissa tai pantavaksi kuolinilmoituksen värssyksi.

Albumin loput neljä muuta kappaletta sitten käsittelevät selvästi veroja. Ne ovat Ilkka Kylävaaran sanoittamia, Kaj Chydeniuksen säveltämiä ja Antti Sarpilan sovittamia. Esittäjinä ovat Heikki Kinnunen, Satu Silvo ja VEROT BOYS -yhtye.

"Verojenkka"-kappaleessa luetellaan runsaat 70 historiamme tuntemaa veroa. Mukana on monia nykyisinkin kannettavia veroja, kuten lahjavero, tullivero, bensiinivero, kirkollisvero ja kunnanvero. Joukossa on useita 1900-luvun lopulla tai 2000-luvulla kumottuja veroja, esimerkiksi vanhanpojanvero, pelikorttivero, pääsylippuvero, tulitikkuvero, margariinivero, väkirehuvero, varallisuusvero ja koiravero. Hyvin monet jenkassa mainitut verot liittyvät luontoistalouden ajan veroparseleihin, esimerkkeinä kalavero, maitovero, turkisvero, heinävero, ruisvero, voivero, tuohivero, päivätyövero ja kyytivero. ${ }^{103}$ Luettelossa on myös sellaisia veroja, joiden nimi kertoo verokohteesta (esim. maavero, metsävero ja manttaalivero), veronkannon ajankohdasta (esim. talvivero ja kesävero) tai rahoituksen kohteesta (esim. piispanvero, voudinvero) taikka veromäärästä (kokovero, täysvero, osavero, puolivero, lisävero).

Verojenkassa mainitaan myös kilttivero, jota harvat muistavat ja jonka olemusta nimikään ei heti paljasta. Förvaltningshistorisk ordbok määrittelee tämän veron:

"Penningskatt som betalades av det medeltida pälsverksskattedistriktet i Finland åt biskopen eller kronan. Avgiften ersatte en gammal skinnskatt." 104

103 Näistä ja monista muistakin veroparseleista ks. tarkemmin Seppälän väitöskirja Viljana, nahkoina, kapakalana - Talonpoikien maksamat kruununverot Suomessa vuosina 1539-1609 (2009).

104 Keskiajalla piispoille maksetut turkikset olivat tavallisia oravannahkoja arvokkaampia, etupäässä näädän ja kärpän nahkoja. Katolisen ajan lopussa ne olivat tulleet niin harvinaisiksi, että piispan saatava yleensä maksettiin rahassa. Kustaa Vaasan aikana nämä verot piispojen muitten verojen mukana joutuivat kruunun haltuun. Kilttiveroa on voitu luonnehtia myös metsästysveroksi. Voionmaa Suomalaisia keskiajan tutkimuksia (1912) s. 65 ss. 
Tässä tarkoitettu kiltti-sana lienee tullut suomeen ruotsista $(k i l t) .{ }^{105}$ Skotlantiin taas se on tainnut päätyä Skandinaviasta: Danish kilte (op) "tuck (up)" and Old Norse kilting "a skirt".

Verojenkassa mainitaan myös ylellisyysvero mutta ei tarkenneta, mitä sillä tarkoitetaan. Ylellisyysverotuksen kulta-aikaa meillä elettiin 1700-luvulla, jolloin kulutusveroa kannettiin mm. hienoista vaatteista, peruukeista ja kahvista. ${ }^{106}$

"Verotango" kuvaa verottajan ahneutta:

Hän käy tölliin, hän käy torppaankin

liian alhainen ei ole maja

oman merkkinsä iskee jo norppaankin

se on hän, se on hän - verottaja.

Hän vie tangossa meidät mukanaan

ottaa pois turhan irtorahan

tangokumppaniks kelpaa kuka vaan

josta jättää hän joskus nahan.

Ja aina ne Ruotsin kuninkaat

oikein ilolla Suomea muisti

kun otti he pellon ja läänitti maat

tuhat lämmöllä pesistä puisti.

Kohta "tuhat lämmöllä pesistä puisti” viitannee sanontaan ”Viekää tuhkatkin pesästä", joka taas liittyy 1600-luvulla säädettyyn salpietariveroon. Tilojen oli toimitettava kruunulle tietty määrä salpietarimultaa, lampaan- tai vuohenlantaa, halkoja, olkia ja tuhkaa. Veron taustalla oli ainainen sodankäynti ja ruudin valmistukseen tarvittava salpietari.

Kappale "Huss ja Andersson" ei kerro uskonpuhdistaja Jan Hussista ja veroprofessori Edward Anderssonista vaan rakennusyrittäjän ja verottajan keskinäisestä vihasta ja heidän elämänsä loppuvaiheista. Laulussa on mm. seuraavat kohdat:

105 Ks. myös Wikipedia Kilt.

106 Yleinen on väite, että meillä olisi peritty myös peiliveroa ja että sitä kierrettiin jakamalla isot peilit pienempiin osiin. Väite lienee virheellinen tai ainakin epätarkka (Taloustaito 17.2.2015). 
Kiinteistöjä bygaa ihmisille Huss

Väinö Hussille on suurta kustannus

siitä hän niin kovin tinkii

suosii mustan duunin rinkii

vikkelää on raksan rahanjuoksutus.

Hussia noin vihaa Håkan Andersson

verottajateräsmiehiä hän on

Hussin polttais nuotiolla

jos sai verot suosiolla

niitä Anderssonin hirmu tarvis on.

Hussin konkurssiin nyt hakee Andersson

laki takaa, monta konstii siinä on

epäilee ja laittaa mätkyn

tuomioista Huss saa sätkyn

dumari ja syyttäjä on Andersson.

Konkassa on Huss ja sairas Andersson

kovin raskas verottajan duuni on

Håkan pannaan vanhainkotiin

Huss saa turvautua Hotiin

sama laitos se on heillä kohtalon.

Siinä seisoo Huss ja Andersson

molemmat he usein väärässäkin on

enää toisiansa ei vihaa

kuolema kun nykii hihaa

ja sen kyyti taitaa olla veroton.

"Veron hetki on kallis" kuvaa verottajan kuoleman jälkeistä aikaa mm. seuraavasti:

Verottaja kuoli, voi harmi

ja joutui taivaisiin

ei purrut St. Peteriin charmi

niin kuin puri se vaivaisiin.

Kun ihminen ihmistä verottaa

hän jakaa ne vuohet ja lampaat

hänet eläimestä vain erottaa

ne pidemmät kulmahampaat. 
Ulkonäkö hyvä on teillä pikku probleemi vaan on että helvetissä sääntönä meillä kahta ei ole perkelettä.

Veroherralle Herra soi armon ja laitatti hommaan iisiin kiitos virkamiehen tarmon pääsi veroparatiisiin!

Luulis riittävän viina ja manna mutta olo on pikkuisen nolla paratiisi ei veroja kanna parasiittina täytyy olla.

\subsubsection{Vilperin perikunta (1999)}

Vilperin perikunta on turkulainen humoristisen iskelmämusiikin yhtye, joka aloitti toimintansa vuonna 1992. Vuonna 1995 se julkaisi ihmisen elämänvaiheista kertovan "Verot ja kuolema”. Siinä todetaan mm.:

Jos velkasi pääset sä kuittaamaan, vielä kaksi on ovella ottajaa:

verot ja kuolema.

Kun muut luopuu sinusta itkien, vain kaksi on seurana ihmisen: verot ja kuolema.

Laulu tuo mieleen kuolemattoman sanonnan "Elämässä on varmaa vain kuolema ja verotus". Sitä on käyttänyt Benjamin Franklin vuonna 1789 USA:n perustuslaista, mutta väite löytyy myös useista aikaisemmista ja myöhemmistä lähteistä. ${ }^{107}$

107 Kanadanranskalainen Céline Dion esitti vuonna 2002 rakkauslaulun ”Rain, Tax (It’s Inevitable)", jonka mukaan sadetta ja veroa ei voi välttää. 


\subsubsection{Veropakolaislauluja (Julle ja Hilipiliboys, Turo's Hevi Gee, Petri Hankonen)}

Julle ja Hilipiliboys on julkaissut vuonna 1992 cd-levyn, jossa on myös "Veropakolaiseksi Somaliaan". ${ }^{108}$ Tuota kappaletta ei ole löytynyt, joten sen sanoma jää nyt arvoitukseksi. ${ }^{109}$ Myöhemmin julkaistun toisen levyn esitetekstissä Jullen musiikkia kuvataan seuraavasti:

Julle on tullut keväällä 1992 tunnetuksi leppoisana huumorimiehenä, johon on jokaisen musiikinkuuntelijan helppo samaistua. Julle Kätkävaaran laulut ovat pääsääntöisesti reippaita ja rempseitä ralleja, mutta Julle osaa myös tarvittaessa esittää lauluja Suomen kansan kipeimmistä tunnoista.

Turo's Hevi Geen huumoriorkesteri on vuonna 2003 julkaissut "Menolipun" sävelellä kappaleen "Verolippu”. Siinä verovelvollinen saa kalliin verolipun ja muuttaa veropakolaiseksi savimajaan Afrikkaan ja mätkyt jäävät Suomeen.

Mätkyt on kansanomainen ilmaus, jolla tarkoitetaan useimmiten (mm. Verohallinnon ohjeissa) jäännösveroa ${ }^{110}$ eli tuloveron sitä osaa, joka tulee maksettavaksi ennakkoveron lisäksi. ${ }^{11}$ On kysytty, miksi jäännösvero on mätky, mutta esimerkiksi auto- tai kiinteistövero ei. Kielitoimiston mukaan mätky kuuluu sellaisten verbien kuin "mätkätä" ja "mätkiä" yhteyteen. Varmaan on ajateltava, että muut veromaksut ovat paremmin ennakoitavissa ja niiden suuruus on selvästi tiedossa. Jäännösveroista taas ei aina tiedä, mitä vähennyksiä viranomainen hyväksyy ja mitä ei. Niinpä voi tuntua siltä, että jäännösverot vain mätkäistään eteen.

108 Ensimmäiset somalit saapuivat Suomeen 1990-luvun alussa poliittisina pakolaisina sen jälkeen, kun Somalia oli keskushallinnon romahdettua ajautunut sekasortoon. Monet suomalaiset suhtautuivat kielteisesti somalien tuloon.

109 Myöskään Julleen ei ole saatu yhteyttä. Suomessa on alle viisi Kätkävaara-sukunimistä. Ainoa nyt tavoitettu Kätkävaara ei ollut koskaan kuullutkaan Julle Kätkävaarasta, joten kysymyksessä saattaa olla taiteilijanimi.

110 Jäännösvero on ruotsiksi kvarskatt. Kvarnskatt taas oli myllyvero, joka liittyi henkiveromme historiaan.

111 Mätkyiksi on saatettu kutsua muitakin ikävyyksiä, kuten arvio- ja harkintaveroja, jälkiveroja, lisäveroja, sakkoja ja takaisin perittävää asumistukea. 
Käsikirjoittaja ja keikkaileva stand up -koomikko Petri Hankonen puolestaan on vuonna 2016 esittänyt kappaleen "Veroparatiisi”, joka on hyvin erilainen kuin edellä kerrottu Klamydian vuonna 1993 julkaistu samanniminen kappale. Hankosen esityksessä on mm. seuraavat kohdat:

Kun mä tämän hoksasin, oli päivä ihanin.

EK lauloi et rikkaat vaan rikastuu.

Sinä sanoit menkäämme paratiisisaarelle.

Mietin nyt veronkierto onnistuu.

Nordeaan kun soitettiin, tilit Panamaan siirrettiin.

Oli suunnitelma niin ovela.

Oi jos sulle voisin näyttää kaikkein kauneimman tämän verosuunnitelmani valtavan, mutta enhän sitä tee.

Hallintarekisteri riittänee, et veroparatiisissa firmat olla saa.

Verotus nollaan pudotettiin.

Valtio haukkas paskaa niin.

Bulvaanin nimiin me firmat laitettiin.

Pientä vilppii tehtiin kai,

lain kirjaimen mukaan vain.

Tästä Alexander puhuu kuiskuttain.

Oi jos sulle voisin näyttää kaikkein kauneimman tämän verosuunnitelmani valtavan, mutta enhän sitä tee.

Koska Wahlroos järkkäilee, et veroparatiisissa firmat olla saa.

Hankosen sävel ja sanat on mukailtu Pauli "Badding" Somerjoen vuonna 1973 esittämästä suositusta paratiisikappaleesta, joka ei liity mitenkään verotukseen vaan on lähinnä rakkauslaulu. Hankosen teemoina ovat kansainvälinen verovälttely, ns. Panama-paperit ja hallintarekisteröinti, jotka aiheet olivat 2010-luvun loppupuolella paljon esillä julkisuudessa. 


\subsubsection{Alkoholi ja verotus, autovero, Yle-vero ja lentovero}

Tutulla, vakavan ponnekkaalla sävelellä ${ }^{12}$ esitettävässä teekkarien juomalaulussa "Ei muuta keinoa" todetaan mm. seuraavaa:

Oi, kallis Suomenmaa, sun lisäveros kuohuja, budjettisi paisuntaa suo mun kestää, kunnes hetki lähtöni lyö. Oon köyhä teekkari.

On isälläni pellot ja metsät, viljat, karjaakin. Silti mulla on verot, peijakas, suuremmat.

Alkoholivero on lauluissa harvemmin esillä, mutta se mainitaan ainakin Chisun (oik. Christel Roosberg, s. Sundberg) kappaleessa "BadenBaden", josta Chisu sai Vuoden biisi -Emman vuonna 2020. Laulussa kerrotaan mm. seuraavaa:

Siis pullotetaan kyyneleet

Myydään ne Baden-Badeniin ${ }^{113}$

Missä Suomen murheet pumpataan suihkulähteisiin Joo, pullotetaan kyyneleet junalla Baden-Badeniin

Missä niissä kylpee turisti ja toinenkin

Niin kansa itki ja talous nousi pian jaloilleen Ja ilo alkoi muttei riitä pelkät onnenkyyneleet

Hallitus mietti pitkään miten tääkin kriisi ratkaistaan

Kunnes joku muisti miten alkoholivero poistetaan

Ja taas pullotetaan kyyneleet

Myydään ne Baden-Badeniin

Missä Suomen murheet pumpataan suihkulähteisiin.

112 Sävelmä on 1700-luvun kansanlaulu, jonka pohjalta Heikki Klemetti Suomen sisällissodan jälkeen (1920) teki armeijalle varsinkin hautajaisissa esitetyn laulun "Oi, kallis Suomenmaa". Vuonna 1940 välirauhan aikana valmistui samanniminen paatokselliseksikin sanottu elokuva, jonka käsikirjoitti Mika Waltari. Wikipedia.

113 Baden-Baden on kylpyläkaupunki eteläisessä Saksassa lähellä Ranskan rajaa. 
Tässä on hieno juoni, mutta alkoholiveron rooli on hieman arvoituksellinen. ${ }^{114}$ Uskottavasti tekijänoikeuksien ja verotuksen asiantuntija JV oli oikeassa esittäessään seuraavan tulkinnan:

Sanoituksissa mainittu alkoholiveron poistaminen liittyy enemmänkin surun kuin ilon lisäämiseen. Suru tuottaa enemmän kyyneleitä kuin ilo, ja jos halutaan lisätä kyyneleitä, on tehokkaampaa lisätä surua kuin iloa. Suru puolestaan lisääntyy, jos alkoholia kulutetaan enemmän, ja alkoholia kulutetaan enemmän, jos sen hinta verotuksen poistamisen vuoksi alenee. Tällöin suru ja kyyneleet lisääntyvät erityisesti siksi, että alkoholi liittyy suureen osaan Suomen väkivaltarikollisuudesta sekä perheväkivallasta ja sen uhasta. Alkoholi lisää täten ison joukon pahoinvointia ja kyyneleitä. Alkoholin suurkulutus liittyy myös työllistymis- ja talousvaikeuksiin, avioeroihin ja niiden aiheuttamiin riitoihin, mahdollisiin ex-puolisoihin kohdistettuihin vainoihin, lasten huolto- ja tapaamisoikeuden vaikeuksiin, elatusriitoihin jne. ja sitä kautta periyttää surun ja kyyneleiden määrän myös seuraavalle sukupolvelle. Toisaalta myös alkoholisoituneen henkilön vanhemmat ja muut sukulaiset saattavat kärsiä ja itkeä enemmän läheisensä alkoholin lisääntyneen käytön vuoksi. Lausuma "muttei riitä pelkät onnenkyyneleet" viittaa siis nimenomaan surunkyyneleiden lisäämiseen alkoholiveron poistamisen avulla.

Vuonna 2013 Spekti (oik. Timo Huhtala) on julkaissut pari laulua, joilla on liittymä verotukseenkin. Kappaleessa "Diktaattorimies" annetaan kyytiä alkoholiverolle ja autoverolle:

Jos mä hallitsisin tätä palloo, siit nousis kyl kohtalainen halloo.

Loppuis ikuiset hallitusväännöt, menis muutenkin uusiks säännöt.

Oon sen verran nero, et ekana lähtis autoista vero

ja tokana tekona verot ois viinasta pois. Eikä maanteillä kameroit ois.

Laulussaan "Eniten vituttaa kaikki" Spekti tuomitsee yleisradioveron. Autovero mainitaan myös Jouni Mäki-Lohiluoman kappaleessa "Transitmies" (2008), jossa todetaan mm.:

114 Sanat tuovat mieleen Kari Tapion esittämän kappaleen "Olen suomalainen”, jonka alussa todetaan: "On täällä kansa, jonka kyyneleistä aikaan saisi aika monta valtamerta." Kyynelissä suolaa on 0,9 \%, ja kyyneleet vievät ajatukset myös suolaveroon ja Intian itsenäistymiseen. 
Mä tiedän mistä nousee tämä miehen itsetunto Jo lapsena se alkoi, kukaties

Ei liity siihen ulkonäkö, viisaus ei kunto - vain Että musta kasvoi transitmies.

On ohjaamossa vielä ylimääräinen tuo penkki, Se täyttää ehdot autoverolain

Sen pohjassa sun jättämäsi ksylitolijenkki, Kun ihanamman muiston sulta sain.

Myös räppäri Sipen kappaleessa ”Tesomajärvelle” esiintyy autovero:

Mitä vitun välii vaik mun laiffi katutasol Mä teen mitä teen sekä sanon mitä haluun Sanoo ei mun auton alla oo ollu alu pallot Mut mä kuulin et tost duunin teost tulis ne jos puskist kasist neljää Mut en oo tuski menos ku mietin kuinka kusist se on ruokatunti lepoo ja iltapäiväst nuppi sekoo kolkyt vuotta luupil eloo jokane päivä huntti kenoo Shellin munkkikahvit, ruutuplus ja vittu autovero.

Lentovero on päässyt mukaan pop-muusikko Aleksanteri Hakaniemen kappaleeseen "Mitä jos ne tajuu" (2020). Laulussa todetaan:

Tein sen lentoverojutun mut en hehkuta somessa koska entä jos se oli virhe?

Lopetin lihan syönnin mut kyllähän toisaalta avokado on hedelmien Hitler Jos äänestän sitä ketä kuuluukin, käytänkö silloin aivojani? Mitä jos ne tajuu

Että mä en tajuu

Että ei oo hajuu yhtään mistään.

\subsubsection{Tullilauluista}

Myös tullit ovat veroja. Suomessa on monta laulua, joissa kerrotaan tullimiehistä. Nuo laulut eivät kuitenkaan näy koskevan tullimaksujen märäämistä vaan enemmänkin salakuljetusta ja huumeiden etsintää. Tullimies on pääosassa seuraavissa: Räyhänhenki "Tuhma tullimies" (2007), Attopojat "Tullimies" (2013) ja Suotaunot "Kunnollinen 
tullimies" (2017). Sivurooli tullimiehellä on esimerkiksi lauluissa Juha Vainio "Vanha salakuljettaja Laitinen" (1986), Klamydia "Perseeseen" (1997), Ruudolf "Hala!" (2004) ja Matti Esko "Rekkamies" (2008).

\subsubsection{Vaihtoehtoinen joululaulu sekä uutta räppiä ja punk-rockia}

Vuonna 2012 julkaistiin Reki Balboan vaihtoehtoinen joululaulualbumi "Ei aina voi olla joulu", joka käsittelee jouluisia aiheita poikkeavista näkökulmista. Mukana on myös kappale "Veronkierto-Vilkku", joka kertoo joulupukin harjoittamasta veronkierrosta ja häntä auttavasta Vilkku-tontusta. Kappale on sävelletty ukulelella soitettavaksi. ${ }^{115}$

Suomen tunnetuimpia räppäreitä on Paleface (oik. Karri Pekka Matias Miettinen). Hän julkaisi vuonna 2010 albumin 'Helsinki Shangri-La”. Siinä on kaksi kappaletta, jossa mainitaan veroistakin. "Talonomistajan" alkupuolella todetaan:

Talonomistaja olin joku vuosi takaperin, talon omistin niin komian ku linnan

Mutta Lapuanliikkeet ja huilutusretket veivät minun taloni hinnan

Mullia oli mulla navetallinen ja meijerirahat ne riitti

Mutta rahat minä vaihdoin hienoihin juomiin ja herrat mua komiasti kiitti

Pikku robba, Erottaja, pääsymaksun velottaja

Huputettu telottaja, poliisit ja verottaja

Paskatöihin Vespalla käy prekariaatti ${ }^{116}$

Barrikaadit Espalla ja pommiattentaatti

Svea-mamman uuma ja Suomineidon loimet

Naapurissa duuma täällä elvytystoimet.

Saman albumin kappaleessa "Merkit" esitetään mm. seuraavaa:

Kvartaalitalous ajaa yhteiskunnan yksiköitä

Suurtyöttömyyttä silti yksinomaan ylitöitä

Prekariaatti maksaa porvariston juhlaöitä

115 Ks. Anders Vuorimaa 6.1.2013 (digimusa.blogspot.com).

116 Prekariaatti viittaa ihmisiin, jotka elävät köyhissä ja epävakaissa oloissa pätkätyöläisinä tai työttöminä ilman mahdollisuutta työmarkkinoilla hyvästäkin koulutuksesta huolimatta (kotus.fi). 
[-- ]

Tsekkaa tuotemerkit, veromerkit

Nousukauden merkit

Kastimerkit kunnia- ja länsiautonmerkit

Puberteetin, pahanolon, masennuksen merkit

Vero-, korva-, liikenne- ja lopunajan merkit

[-- ]

Harmi ettei Irwin-vainaa hoilaa enää.

Vuonna 2011 Juju (Julius Sarisalmi) räppäsi kappaleen ”Tonni”, jossa verotkin mainitaan:

Mul oli hetki sitte tonni

Nyt se meni

Ja samal meni koko onni

Voi pyhä sylvi, suussa oli purkkaa

Nyt on vaa sylkee, siitä pitää päästä eroo

Tuu ottaa multa vielä vero, vie kaikki.

Vuonna 2012 ilmestyi hiphoppari Huge L:n (oik. Kimmo Huusko) "Herra Huu - Ei toivottu lastenlaulu", jossa mm. todetaan:

Kivistää kuulla niist nimistä

Mä oon aikoi sitten poistunut rivistä

Ei nimismies tääl ketään piristä

Eikä oppikirja tyhmää sivistä

Maksa verot ja pidä turpas kii

Tee perheidylli vaik ilman kumppanii.

Suomalainen Anal Paprika-yhtye ${ }^{117}$ on julkaissut hyvin kiro- ja rumasanapitoisen kappaleen "Myö ei makseta veroja" (2012). Perusteeksi esitetään, ettei veronmaksusta ole hyötyä.

Elastinen (oik. Kimmo Laiho) on tehnyt yhdessä Timo Snellmanin kanssa kappaleen "Pieni Huijaus - Kuutamokeikkaa" (2012), jossa todetaan mm. seuraavaa:

117 Anal Paprika on myös vuonna 1995 kuvattu elokuva, jonka pääesiintyjiä on Unkarissa syntynyt pornotähti Erika Bella. 
Viis veisaan verokorteista,

Työtahti ei näy tiliotteista.

Ne on kenkälaatikoissa, paljonko veikkaat?

Minä ja Timo tehään kuutamokeikkaa.

Jos meille maksetaan kaks ja siitä tilitetään tonni.

Ja vihanen veri virtaa läpi mun valtimon,

Jos valtio verottaa mua, ni mä verotan valtioo.

Kuitit täsmää, ota verottaja iisii,

Paan joulun sulle verokortin veroparatiisist.

Portion Boys on julkaissut kappaleen "Päivit tua menee" (2019). Siinä luetellaan monenlaisia murheita, joukossa myös veromätkyt:
Poissa uni
Puhkes kumi
Veromätkyt
Tippuri
Sauna palo
Koira karkas
Kahvi loppu
Punkki puri.

Mc Mane \& Sarkastinen on räpännyt hyvin pitkän laulun ”Ulkomaille", jossa todetaan mm. seuraavaa:

Suomessa verotus hämmentävää

Suomessa ei musiikki elätä säveltäjää

Suomessa työttömyys on hävettävää

Suomessa aina kädet jäässä

[- - ]

ulkomailla voi luottaa ihmisiin jos tulee lama ja

Suomessa taas häviää kämpästä kaikki tavarat

ulkolainen voittaa aina, Suomessa ei käy tuuri

ne aikoo siirtää tänne Jerusalemista itkumuurin.

SRKMXTP3! on julkaissut rap-kappaleen "Verotus" (2015). Siinä käsitellään $\mathrm{mm}$. verotuksen ankaruutta, veron kiertämistä, harmaata taloutta, holdingyhtiöitä ja veroparatiiseja ja mainitaan sekin, että ikuista on vain verotus ja kuolema. 
Suomalainen Pax Americana ${ }^{118}$ julkaisi vuonna 2016 albumin "For Your Own Good". Sen lopussa olivat kappaleet rock-punk-kappaleet "Lisää veroja (niille)" ja "Palkat, verot ja elintasoerot". Laulujen veropoliittinen sanoma vaikuttaa lähinnä kriittiseltä.

Vuonna 2017 Narri esitti silloiseen pääministeriin Juha Sipilään liittyvän kappaleen "Vakuutuskuori", jossa verotuskin on mukana. Samana vuonna Loiriplukarilta (oik. Kalle Taivainen) ilmestyi kappale "Ei Voi Laittaa Verotukseen", jossa kerta toisensa jälkeen toistuu tuo epätoivoista veroilmoituksen tekemistä kuvaava lausahdus. Antti Tuisku puolestaan on samana vuonna julkaissut laulun 'Rahan takii", jonka mukaan on tosi kiva maksaa tellit, lellit, sähkö, puhelin, puurot, vellit, vuokra, mätkyt, netti, velat, verot, korot, korkojen korot. Rapartisti Kube (oik. Jussi Tapani Hauta-aho) suhtautui veronmaksuun kielteisemmin. Hänen vuonna 2018 julkaistuun albumiinsa "Poliittisesti Correcti” sisältyvässä kappaleessa todetaan: "Mä en maksa duussei enkä veroi mä vaan otan.” Duussi voi slangissa tarkoittaa esimerkiksi lääke- tai muuta annosta (engl. dose) taikka tulli- tai muita maksuja (engl. dues), ehkä myös rahaa (engl. dough). ${ }^{119}$

\subsubsection{Henkivero (poll tax) protestilauluissa}

\subsubsection{Henkiveron käsite, historia ja suhde muihin veroihin}

Erittäin vanhoja verolajeja ovat kiinteistön arvoon kaavamaisesti perustuvat tuottoverot, esimerkiksi maatalous- ja metsäverotus sekä asuntovero. Tällaisista tuottoveroista meillä on jäljellä vain kunnallinen kiinteistövero.

Toinen ryhmä ikivanhoja veroja ovat päälukuun perustuvat verot, joita jokaisen on ollut lähtökohtaisesti maksettava tulo- ja

118 Pax Americanalla (vrt. Pax Romana) tarkoitetaan yleensä II maailmansodan jälkeistä melko rauhanomaista aikaa, joka pohjautui pitkälti USA:n taloudelliseen ja sotilaalliseen mahtiin. Pax Americanan on sanottu päättyneen Kabulissa elokuussa 2021 (The Guardian 20.8.2021).

119 "Dough" tarkoittaa myös taikinaa. The Kinksin Sunny Afternoon alkaa "The tax man's taken all my dough", jolle Google-kääntäjä tarjoaa suomennosta "Veromies on ottanut kaiken taikinani”. Kuten edellä on kerrottu, Pertti Reposen suomenkielisessä versiossa tuo kohta kuuluu "Kun verot veivät rahani". 
varallisuustasosta riippumatta sama määrä. Tällaisella verolla on ollut monia virallisia ja epävirallisia nimiä. Suomen kielessä tätä veroa on kutsuttu mm. henkiveroksi tai -maksuksi, pääveroksi, pollaveroksi, tasaveroksi ja könttäsummaveroksi. Ruotsissa on käytetty termejä kapitationsskatt, huvudskatt ja koppskatt. ${ }^{120}$ Pohjana on latinan päätä tarkoittava sana caput. Englannin kielessä käytetään yleensä termiä poll tax. Poll on vanhahtava päätä tai pään yläosaa merkitsevä sana, jolla tarkoitetaan nykyisin myös äänestystä ja mielipidekyselyä.

Suomessa henkiveroa kannettiin 1600-luvulta lähtien. Tämän veron perimisestä luovuttiin 1920-luvun puolivälissä, jolloin sen osuus valtion verotuloista oli enää $0,4 \%$. Henkiveron poistamista myös vastustettiin. Valtiovarainvaliokunnan mietintöön jätetyssä poliittisen oikeiston vastalauseessa todettiin:

"Mielestämme on oikein, että henkiraha ainoana meillä voimassaolevana verona, jota suorittamalla kaikki kansalaiset tasavertaisesti ottavat osaa valtiomenoihin, pysytetään edelleen voimassa." ${ }^{21}$

Suomen verolauluissa henkivero on mainittu edellä selostetussa Heikki Kinnusen ja Satu Silvon esittämässä "Verojenkassa”, jossa luetellaan useita muitakin jo haudattuja verojamme.

120 Ruotsissa 1600-luvulta asti kannettu henkivero tunnettiin myös nimellä "mantalspenningar". Tuota termiä ei pidä sekoittaa käsitteeseen "mantalsränta", joka liittyi maan verottamiseen. Suomessa manttaalin merkitys verolukuna väheni olennaisesti vuonna 1924, kun eräitä maaveroja lakkautettiin. Lopullisesti kiinteistöjen manttaalimaksut siirtyivät historiaan 1990-luvun alussa kiinteistöveron säätämisen yhteydessä. Lähde Manttaali - miesluvusta tuottavuuden mitaksi, Maankäyttö 2/2013 s. 24-26.

121 Raamatussakin tunnetaan henkiverot. Toisessa Mooseksen kirjassa (30:11-16) todetaan pyhäkön tarpeisiin suoritettavasta maksusta mm. seuraavaa: "Herra sanoi Moosekselle: 'Kun tarkastat israelilaiset ja lasket heidän soturiensa lukumäärän, heidän tulee samalla antaa Herralle maksu henkensä lunnaiksi, ettei mikään vitsaus kohtaisi heitä tarkastuksen vuoksi. Jokainen, joka joutuu mukaan tarkastukseen, maksakoon puoli sekeliä hopeaa punnittuna pyhäkkösekelin painon mukaan - yksi sekeli on kaksikymmentä geraa - ja tämä puoli sekeliä on uhrilahja Herralle. Jokainen tarkastukseen joutuva, kaksikymmenvuotias tai sitä vanhempi, maksakoon tämän uhrilahjan Herralle. Kun annatte uhrilahjan Herralle henkenne lunnaiksi, älköön rikas antako puolta sekeliä enempääälköönkä köyhä sen vähempää. Kerää lunnashopea israelilaisilta ja käytä se pyhäkköteltan jumalanpalveluskuluihin. Se on Herran edessä vakuutena siitä, että teidän henkenne on lunastettu.' "' 


\subsubsection{Thatcher ja poll tax verolauluissa}

Britanniassa Margaret Thatcherin konservatiivisen hallituksen aikana aivan 1980- ja 1990-lukujen vaihteessa säädettiin paikallisveroksi Community charge, joka muistetaan nimellä poll tax ${ }^{122}$ ja joka korvasi aikaisemman asuntotuloveron. Uusi vero, joka merkitsi historiallista käännettä taaksepäin, ${ }^{123}$ herätti laajaa vastustusta ja protesteja. ${ }^{124}$ Poll taxista luovuttiin vuonna 1993, ja se korvattiin kunnallisella asumisverolla (council tax), joka perustuu asunnon arvoon ja muistuttaa mm. suomalaista kiinteistöveroa.

Britannian poll tax on näkynyt taiteessa protestilauluina. Skotlantilainen vuonna 1979 perustettu The Exploited julkaisi vuonna 1990 kappaleen "Don't Pay the Poll Tax". Sen sanoissa todetaan mm.:

Maggie said community charge

You better watch out the governments at large

Don't pay the poll tax

Stick it up her arse.

Poll tax -verosta on laulettu Britannian ulkopuolellakin. Michelle Shocked, oikealta nimeltään Karen Michelle Johnston (s. 1962), on yhdysvaltalainen laulaja-lauluntekijä, jonka musiikissa ja esiintymisissä on vaikutteita hänen texasilaisista juuristaan ja poliittisesta aktiivisuudestaan. Hänen vuonna 2004 ilmestynyt "Poll Tax Song" -kappaleensa kertoo Thatcherin ajan verosta. Laulun sanoissa on $\mathrm{mm}$. seuraavat kohdat:

Pay the poll tax

You must be joking

Ha, ha, ha, ha

It is Thatcher, who's revolting

Not I Lord, no not I.

122 Tarkemmin esim. Wikipedia Poll tax (Great Britain) ja Poll tax riots.

123 Verohistoriasta muistetaan Englannissa vuonna 1380 säädetty poll tax. Siihen liittyi ns. Wat Tylerin kapina, joka oli Euroopan ensimmäisiä suuria talonpoikaiskapinoita. Wat Tyler surmasi veronkantajan. Kapina saatiin kukistetuksi, mutta sen laukaisseesta henkiverosta sillä kertaa luovuttiin. Linnakangas Väkivalta, seksi ja rikokset verotuksessa, Terttu Utriaisen juhlakirja (2006) s. 332-333.

124 Lontoon Trafalgar Squaren poll tax -mellakassa 31.3.1990 loukkaantui 113 ja pidätettiin 339 ihmistä. 
Myös yhdysvaltalainen kantrilaulaja Mike Lane on vuonna 2008 julkaissut samannimisen kappaleen, jonka aiheena oli Thatcher ja poll tax.

\subsubsection{Venäläinen lapsettomuusverolaulu}

Mikhail Tanich ja Sergey Korzhukov ovat vuonna 1990 perustaneet Venäjällä Lesopobal-nimisen yhtyeen, jonka tyylilajina on chanson. Yhtyeen nimi viittaa neuvostovallan aikaisiin Siperian pakkotyöleireihin. Yhtye on julkaissut laulun "Nalog" (suom. vero), jonka Googlen kääntämissä sanoissa todetaan mm.:

I couldn't bear children,

Couldn't give birth,

And they say to me: pay the tax!

Pay the tax!

And I say, where's the woman?

But at least, they say, the judge in court!

And I say: I couldn't do it!

That's it, they say: and pay the tax!

I'll put my boots in the dryer,

And it happens sometimes -

Suddenly dream Yes not that-nibut,

And maiden..., Yes-Yes!

Well they sent it to the brigade

At least for the night,

At least fucking,

And they charge me taxes,

I'm supposed to take this with me!

Wikipedian mukaan tämä laulu keskittyy Neuvostoliiton aikana käyttöön otettuun lapsettomuusveroon. ${ }^{125}$ Vero oli $6 \%$ aikuiselta, jolla ei

125 Suomenkin verojärjestelmässä on ollut piirteitä lapsettomuusverosta (ns. vanhanpojan ja -piian vero). Suurempia perhekokoja on vaadittu erityisesti sota-aikana. Ks. mm. M. Lausa (oik. Lauri Mikael Sainio) "Mihin menet Suomen kansa?" (1942), esim. s. 220: "Väkiluvun lisääntymisestä, kansan voiman kasvattamisesta, on hyötyä kaikille, kun ensin on tehty elintilaa tälle voimakasvulle." Sopivimpana keinona Lausa piti lapsettomuusverotusta. - Vuonna 2013 tehty kansalaisaloite, jossa vaadittiin lapsettomille naisille lisäveroa, sai vain 26 kannattajaa. Ks. myös Linnakangas Kansanvalta, ikä, vero-oikeus (2020) s. 138 ss. ja Linnakangas 
ollut lasta. ${ }^{126}$ Kappaleessa vankilassa oleva laulaja valittaa, että hänen on pakko maksaa tämä vero, mutta vartijat kieltäytyvät antamasta hänelle naista lisääntymistä varten.

\subsubsection{Viron, Ruotsin ja Norjan 2000-luvun verolauluja}

Viron uutta itsenäistymistä 1990-luvun alussa edistettiin kansallistunteeseen vetoavilla laulujuhlillakin, mutta veroesiintymiä senaikaisista lauluista ei ole löytynyt. Virolainen punk-yhtye Psychoterror on esittänyt 2000-luvulla noin minuutin pituisen kappaleen "Ära maksa maksu!", mutta sen kritiikki liittyy itsenäistymisen jälkeiseen aikaan. Laulussa arvostellaan vallassa olevia lipeväkielisiä herroja turhista lupauksista. Laulu päättyy seuraaviin veroprotestiin yllyttäviin sanoihin:

Ära kuse

Toimi parem nii

Ära maksa riigimaksu.

Skandinaavisten verolaulujen löytämistä hankaloittaa skatt-sana. Se johdattaa esimerkiksi amerikkalaiseen Skatt Brothers -yhtyeeseen tai Björn Afzeliuksen rakkauslauluun "Livets skatt" (1980), jossa skatt tarkoittaa aarretta. ${ }^{127}$ Veroista ei näy olevan kyse myöskään norjalaisessa kappaleessa "Samle skatter" (2021), jonka lauloivat Maja Neeras ja Svein Finneide.

Netissä on Aftonbladetin uutinen 16.8.2015 protestilaulusta tamponiveroa vastaan. Kun sitä klikkaa, näyttöön tulee kuitenkin ilmoitus: "Vi har endast rättigheter att spela detta innehåll i Sverige."

- Juanto Synti- ja haittaverokirja - Anekaupasta paheveroihin ja kompensaatiomaksuihin (2020) s. 175 ss.

126 Kyseinen 1940-luvun alussa säädetty vero koski 18-50-vuotiaita miehiä ja 18-45-vuotiaita naisia. fi.garynevillegasm.com.

127 Skatt-sana esiintyy myös J. L. Runebergin sanoittamassa ruotsinkielisen virsikirjan virressä numero 199. Suomenkielisessä virsikirjassa tuo virsi on numerolla 183

("On meillä aarre verraton"). 
Changemaker on Suomessakin toimiva nuorten ja nuorten aikuisten verkosto, joka tarjoaa vaikuttamismahdollisuuksia kehityskysymyksistä kiinnostuneille sekä pyrkii puuttumaan köyhyyden ja epäoikeudenmukaisuuden rakenteellisiin syihin. Toiminta on lähtöisin Norjasta, jossa verkosto on toiminut vuodesta 1992 lähtien. Norjan Changemaker sanoitti joulun alla 2017 vanhoja joululauluja uudelleen niin, että teemana oli verojen välttely. Esimerkiksi suomalaisillekin tuttu virsi "Maa on niin kaunis" kuuluu uudessa versiossa seuraavasti:

Deilig er jorden

Trygg er veldferdstaten

fæl er profittens pilgrimsgang.

Penger forsvinner

De holdes skjult så

Går de til paradis med sang

Penger har kommet,

Penger har forsvunnet, rikdom har fulgt revisornes gang.

Aldri forandres

skattesystemene

til profittens glade pilgrimssang.

Kansainvälistä veropakoilua käsitellään myös ruotsalaisen Simon Ahlströmin vuonna 2019 säveltämässä, sanoittamassa ja esittämässä kappaleessa Skattevisan. Laulu on vastaus Leif Östlingille ${ }^{128}$, joka Panama-vuodon paljastuttua kysyi: "Va fan får jag för pengarna?"

En del har stålar, nån av dom skrålar, över Sveriges skattesystem.

En del dras till en oas,

där skatt är ett ytterst litet problem.

Dom drar till paradis, med sina flis,

för att undanhålla slantarna.

Sen kritiserar man, ordagrant -

"Va' fan får jag för pengarna?"

Dom går till omsorg, dom går till sjukvård,

128 Leif Östling, entinen Scanian toimitusjohtaja, joutui vuonna 2017 jättämään puheenjohtajuuden Ruotsin elinkeinoelämän keskusjärjestössä, kun Panamavuodossa kävi ilmi, että hän oli veroja välttääkseen sijoittanut suuria summia maltalaiseen yritykseen. 
dom går till skola, försvar och kultur.

Dom går till vägar, dom går till tågen, dom går till rättsväsende och polis.

Men i praktiken, i politiken, bör man ändra lite i lagtexten.

Så ingen drar från sitt ansvar att hjälpa varann, det är hela grundidén.

Vuonna 2019 Ruotsissa julkaistiin myös Jan Mattssonin sanoittama ja säveltämä opettavainen "Sjung språket" -kappale "Skattsången":

Om vi vill stödja dom som har det svårt då måste vi alla hjälpas åt Det finns ett sätt som slår det mesta när vi vill varandras bästa Det fungerar under förutsättning att alla som kan betalar skatt Skatt är ett sätt att dela med sig

Skatt är ett sätt att dela rättvist

Skatt är ett sätt att betala vård, skola och omsorg

Skatt är bra för de flesta

Skatt är bra för din nästa.

\subsubsection{Saksan-, ranskan- ja espanjankielisistä verolauluista}

Saksan kielessä vaikeuksia tuottaa se, että Steuer voi artikkelista riippuen olla joko (die) "vero" tai (das) ”ohjauspyörä". Jälkimmäiseen liittyy Roger Ciceron "Hinterm Steuer".

Veroista puolestaan kertoo liittokansleri Gerhard Schröderiä pilkkaava Die Gerd-Show'n "Der Steuersong" (2002), jota myytiin yli miljoona kappaletta. Laulun sanoissa on monia oikeita tai kuviteltuja veroja: koiravero, tupakkavero, ajoneuvovero, ympäristövero, alkoholivero, huonon sään vero, hiusvärivero, maanpinnan käyttövero, hengitysvero, ruuansulatusvero.

Ranskasta löytyy sanoilla "impôt" ja "chanson" Les Inconnus -nimisen ranskalaisen humoristiyhtyeen laulu (1991), jossa räpätään seuraavista veroista: kiinteistövero, ammattivero, henkilöstövero, savukevero, aspiriinivero, alkoholiverot, rekisteröintimaksut, paikalliset verot, välittömät verot, välilliset verot, ennakkoverot, varallisuusverot, suurten omaisuuksien verot, kuivuusverot, tuloverot, vuotuiset 
kiinteät verot, solidaarisuusverot, eläköitymistä edeltävät maksut, eläköitymisen jälkeiset maksut, arvonlisävero ja perintövero.

Meksikolainen El Tri -niminen rock-yhtye on vuonna 2003 julkaissut kappaleen "Nuestros impuestos" (Meidän veromme). Sen mukaan päivä päivältä joutuu maksamaan lisää veroja. Argentiinalainen rockyhtye Turfon vuonna 2004 levyttänyt espanjankielisen kappaleen "El impuesto", jossa sanotaan, että veroa ei makseta. Laulun verosanoma vaikuttaa muutoin epäselvältä.

\subsection{Verolajeittainen tarkastelu}

Taiteessa käsitellään yleensä sellaisia veroja, joita on kannettu teoksen tekohetkellä tai teoksen kuvaamalla aikakaudella. Tämän vuoksi vanhimmat veromaininnat taiteessa liittyvät maaveroihin, henkiveroihin ja tulleihin.

Nykyajan taiteessa veroteemat liittyvät ennen kaikkea tuloverotukseen, joka kehittyi erityisesti 1900-luvulla keskeiseksi verolajiksi, ns. kuningasveroksi. Viime aikoina myös kansainväliset tuloverotusongelmat ovat kiinnostaneet taiteilijoita. Arvonlisäverotus, joka on verohistoriassa melko uusi keksintö, on valtion verotulojen kannalta nykyisin yhtä tärkeä kuin tuloverotus, ja se on alkanut näkyä jo taiteessakin.

Jotkut taiteilijat käsittelevät kerralla vain yhtä veroa. Toisaalta on sellaisiakin, joiden teoksissa esiintyy suuri kirjo nykyisiä tai entisiä taikka keksittyjä veroja. Seuraavaksi siirrytään tarkastelemaan oikeustieteellisesti taiteen verokysymyksiä verolajeittain aloittaen tuloverotuksesta ja edeten lopulta arvonimiveroon. 



\section{III \\ Osa}

\section{Tuloverotus}

\subsection{Tuloverotuksen synty ja kehitys}

Nettotuloon perustuvan tuloverotuksen lähtölaukauksena pidetään Isossa-Britanniassa vuonna 1799 säädettyä tilapäistä veroa Napoleonia vastaan käydyn sodan rahoittamiseksi. Jatkuvasti tuloverotus on ollut Isossa-Britanniassa käytössä vuodesta 1842 . Siellä vero ei kuitenkaan perustunut kokonaistuloon vaan tulon lähteisiin.

Tuloverotuksessa on ensin selvitettävä, mitä tulolla tarkoitetaan. Nettotulon verotuksessa tulosta vähennetään tulonhankkimiskulut. Laajimpana tulokäsite on varallisuudenlisäysteoriassa. Sen mukaan kaikki varallisuudenlisäykset ovat veronalaista tuloa. Suppeampia ovat lähdeteoriat; niiden mukaan tuloa on vain sellainen omaisuudenlisäys, joka saadaan laissa mainituista, tuloa säännöllisesti tuottavista lähteistä. Silloin ei veroteta sellaista, mitä saadaan satunnaisesti.

Vuosi 1865 oli merkittävä Suomen verohistoriassa. Tuolloin annettiin Keisarillisen Majesteetin Armollinen Julistus siitä suostuntaverosta, jonka Suomenmaan säädyt olivat ottaneet maksaakseen. Valtion tuloveroa kutsuttiin suostunnaksi, kuten yleensä muitakin sellaisia veroja, joita hallitsija ei voinut määrätä ilman säätyjen suostumusta. 
Näin säädettiin Suomessa ensi kertaa yleinen kokonaistuloon perustuva tuloverotus. Se tapahtui samaan aikaan kuntauudistuksen ja tuloveroperusteisen kunnallisveron säätämisen kanssa. Ä̈nioikeus vaaleissa nähtiin tuolloin veronmaksuun liittyvänä oikeutena: yksi veroäyri vastasi yhtä ääntä, mutta kaupungeissa korkein mahdollinen yhden verovelvollisen äänimäärä oli 25. Äänioikeuden sitominen verovelvollisuuteen ei poikennut valtiopäivävaaleissa noudatetusta käytännöstä. Porvarissäädyn vaaleissa ja talonpoikaissäädyn valitsijamiesvaaleissa noudatettiin samantapaista periaatetta.

Verovelvollisen tuli suostuntaverokomitealle ilmoittaa, kuinka suureksi hän arvaa (eli arvioi) puhtaan tulonsa viimeksi kuluneelta vuodelta. Ilmoittamisvelvollisuuden merkitys jäi todellisuudessa vähäiseksi, koska velvollisuutta ei ollut sanktioitu veronkorotuksella. Puhtaan tulon selville saaminen oli vaikeaa, ja tulojen todellinen määrä jäikin usein verovelvollisen moraalin varaan. Valtion tuloverotuksen tuotot jäivät hyvin vähäisiksi, ja tuloverosta luovuttiin vuoden 1885 valtiopäivillä. Valtiopäivillä korostettiin, että tuloverorasituksen kohdistuminen oli erittäin epätasaista, minkä vuoksi tuota veroa valtion kannatti käyttää vain, jos muut rahoituslähteet eivät riittäneet. Viitattiin myös järjestelmän aiheuttamiin kohtuuttoman suuriin kuluihin.

Valtion ensimmäisen tuloverotuksen epäonnistuminen johtui osittain talouden rakenteesta, sillä toimiva laajapohjainen nettotulojen perusteella tapahtuva verotus olisi edellyttänyt markkinataloutta, teollistuneisuutta ja rahataloutta. Epäonnistumiseen vaikutti myös liberalistisen veropolitiikan mukainen varsin torjuva suhtautuminen ilmoittamisvelvollisuuteen. Jonkinlaista ristiriitaa oli yksityisyyden korostamisella ja sillä näkemyksellä, että lautakunta kyllä tietää ihmisten oikeat tulot. Käsitys valtion yleisen tuloveron tarpeellisuudesta vahvistui 1800-luvun lopussa ja 1900-luvun alussa. Mallia haettiin erityisesti Saksasta. I maailmansodan rahoittamiseen käytettiin Suomessa lainanoton lisäksi ns. sotaveroja, jotka otettiin alun perin käyttöön eduskunta sivuuttaen.

Suomessa on ollut pysyvä valtion tuloverotus 1920-luvun alusta alkaen. 1970-luvun puoliväliin asti puolisoihin sovellettiin valtionverotuksessa yhteisverotusta. Tuloverotustamme uudistettiin 1980-luvun lopulla nousukauden aikana voimakkaasti ns. kokonaisverouudistuksessa, jolloin neutraalisuutta lisättiin laajentamalla 
veropohjaa ja alentamalla verokantoja hakemalla virikkeitä USA:n verouudistuksesta. Vuonna 1993 ns. suuressa verouudistuksessa laman aikana sen sijaan ansiotulot ja pääomatulot erotettiin omilla verokannoilla verotettaviksi, mihin saatiin idea varsinkin Ruotsista. 2000-luvun aineelliset tuloverotusmuutokset ovat olleet suhteellisen pieniä.

Tuloverotuksessamme kaikki tulot, joita ei ole säädetty verovapaiksi, ovat veronalaisia. Nettotulon verotuksen perusajatuksia on myös, että kaikki tulon hankkimiseksi ja säilyttämiseksi suoritetut menot ovat täysimääräisesti vähennyskelpoisia. Lähtökohtana on subjektiivinen arviointi, jonka mukaan verovelvollisella on oikeus pyrkiä taloudelliseen tulokseen parhaaksi katsomallaan tavalla. Olennaista on verovelvollisen oma vakaa tulonhankkimistarkoitus, ei verottajan näkemys sopivista tulonhankkimiskeinoista.

\subsection{Varallisuusverosta ja kiinteistöverosta}

\subsubsection{Varallisuusveron historia}

Varallisuusverot eli omaisuusverot voidaan jakaa kolmeen päätyyppiin: tuottoveroon, konfiskaatioon ja pääomatulon lisäveroon. Tuottoveroissa verotus kohdistuu kaavamaisesti esimerkiksi maan ja rakennusten arvioituun tuottokykyyn tai elinkeinotoiminnan laajuuteen. Nykyinen kiinteistöveromme kuuluu tähän ryhmään. Varsinkaan kriisiaikoina varallisuuden verotus ei ole aina rajoittunut tuottoon, vaan on turvauduttu myös pakko-oton luonteiseen konfiskatoriseen verotukseen.

Todellisen tulon verottamiseen perustuva yleinen tuloverotus syntyi 1800-luvun lopulla, kuten edellä mainittiin. Sen rinnalle kehitettiin 1800- ja 1900-lukujen vaihteessa uudentyyppinen koko nettovarallisuuden varallisuusvero, jota on luonnehdittu vakautetun tulon eli pääomatulon lisäveroksi. Suomessa tällainen vero otettiin käyttöön vuonna 1918.

Varallisuusvero oli meillä alkuaikoina valtiontaloudellisesti merkittävä. Sen osuus 1920- ja 1930-luvuilla valtion tulo- ja omaisuusveron 
yhteistuotosta oli 20-30 \%, ja tämän veron tuotosta kaksi kolmasosaa kertyi osakeyhtiöiltä.

Ajan myötä kansalaisten varallisuus kasvoi, mutta varallisuusveron tuotolle kävi päinvastoin. Se alkoi voimakkaasti hiipua 1960-luvulla, kun se poistettiin osakeyhtiöiltä, ja vähitellen varallisuusverotusta lievennettiin niin, että 2000-luvulle tultaessa sen tuotto oli jo erittäin vaatimaton. Varallisuusveron heikkoon tilaan vaikuttivat verokannan alentamisen lisäksi mm. laajat verovapaudet ja omaisuuden varovainen arvostus; vuodelta 2003 varallisuusveroa määrättiin vain noin 120 miljoonaa euroa. Verovelvollisten verotettavasta bruttovarallisuudesta jo lähes $80 \%$ muodostui kiinteistöistä, asunto-osakkeista sekä maa- ja metsätalouden varallisuudesta. Loppuosa muodostui lähinnä arvopapereista, joista pääosa oli osakkeita. Useat muut maat olivat tuolloin jo luopuneet varallisuusverosta.

Yritys- ja pääomaverouudistuksen myötä osakeomistuksen verotus kiristyi, kun yhtiöveron hyvitysjärjestelmästä luovuttiin ja siirryttiin osinkona jaetun voiton osittaiseen kahdenkertaiseen verotukseen. Osinkoverotuksen muutos antoi aiheen tarkistaa osakeomistukseen kohdistuvan verotuksen kokonaisuutta. Omistuksen verottamisen sijasta pidettiin tarkoituksenmukaisempana kohdistaa osakeomistuksen verotus tuoton eli osinkojen verotukseen. Siksi osakeomistusten

varallisuusverotuksesta ehdotettiin luovuttavaksi.

Pelkkä osakkeiden varallisuusverotuksesta luopuminen olisi merkinnyt sitä, että varallisuusveroa olisi kertynyt enää lähinnä kiinteistövarallisuudesta, joka oli ja on yhä kiinteistöverotuksen piirissä. Kiinteistöverotuksen taustanäkökohdat olivat osin toiset kuin varallisuusverotuksessa, mutta yhteistä näille veromuodoille oli se, että vero kohdistui varallisuuteen sen todellisesta tuotosta riippumatta. Osakkeiden varallisuusverotuksesta luopumisen jälkeen ei ollut - myös varallisuusverotuksen hallinnolliset kustannukset huomioon ottaen - syytä ylläpitää kiinteistöjen verotuksessa kahta päällekkäistä veromuotoa. Hallitus esitti varallisuusverotuksesta luopumista vuoden 2006 alusta, ja eduskunnassa esitys hyväksyttiin äänestyksen jälkeen. 


\subsubsection{Taide-esineet kumotussa varallisuusverotuksessa}

Taiteen asemasta varallisuusverotuksessa oli jo vuonna 1920 säädetyssä tulo- ja omaisuusverolaissa erityissäännös. Lain 15 \$:n 2 kohdan mukaan varoiksi ei luettu "taideteoksia sekä kirja-, taide- ja muita niihin verrattavia kokoelmia, jollei omistaja tee niillä kauppaa tai muuten hanki niistä itselleen tuloa”. Säännös säilyi samanlaisena vuonna 1924 säädetyssä tulo- ja omaisuusverolaissa sekä vuonna 1943 säädetyssä tulo- ja omaisuusverolaissa (33 \$:n 2 kohta). Tätä verovapautta kommentoitiin Aarne Rekolan kirjassa Tulo- ja omaisuusverolaki (1947) seuraavasti (s. 306-307):

Kysymyksessä olevan verovapauden syynä ovat samat seikat, jotka koskevat [ - ] koti-irtaimistoa, minkä ohessa säännöksellä on pyritty edistämään taiteita siten, että jos koteihin hankituista taide-esineistä ja kirjoista täytyisi maksaa omaisuusveroa, ihmiset ostaisivat niitä vähemmän kuin nykyään. [ - - ] Paitsi kodeissa sisällä olevia taide-esineitä voidaan verovapaina pitää myös ulkona esim. puutarhassa olevia veistoksia, elleivät ne ole niin taloon kiinnitettyjä, että niitä on pidettävä kiinteistön osina, jolloin ne lienee otettava huomioon kiinteistön verotusarvoa määrättäessä.

Taide-esineiden tai kirjallisuuden kauppavarastot eivät ole verovapaita eivätkä kokoelmat, joilla omistaja muutoin ammattinaan hankkii itselleen tuloja. Taiteilijan omassa hallussa olevia valmiita tuotteita on tuskin kuitenkaan syytä pitää kauppavarastona ja sen vuoksi veronalaisina, vaikka ne olisi valmistettukin myyntiä varten, ellei taiteilijalla ole niitä varten myymälää tai muuta sellaista liikettä. Omistajan voidaan katsoa hankkivan taide-esineistä ammattinaan tuloa, jos hän esim. pitää kokoelmiaan maksua vastaan julkisesti nähtävinä tai muuten edustaa itselleen korvausta niiden näkemisestä tai käyttämisestä. Kokoelmaesineiden satunnaista myyntiä ei kuitenkaan voida pitää sellaisena tulon hankkimisena kokoelmasta, joka poistaisi sen verovapauden, vaan täytyy tällaisen myynnin olla jossakin määrin ammattimaista.

Vuonna 1967 hallitus esitti (HE 100/1967) säännöksen muuttamista siten, että tavanomaista arvokkaammat taide-esineet olisivat tulleet veronalaisiksi varoiksi. Esitys kuitenkin kaatui eduskunnan verovaliokunnassa, joka totesi: 
Voimassa olevan lain mukaanhan varoiksi ei lueta taideteoksia eikä taidekokoelmia, jollei omistaja tee niillä kauppaa tai muutoin ammattinaan hanki niistä tuloja. Vaikka taideteosten veronalaisiksi varoiksi lukeminen saattaisikin olla perusteltua silloinkin, kun niitä pidetään sijoituskohteena, valiokunta kuitenkaan ei ole pitänyt taideteosten nykyistä laajempaa verottamista tarkoituksenmukaisena niiden haittojen vuoksi, joita verotuksen kiristämisestä saattaisi aiheutua taideteosten ostamiselle ja taidekokoelmien syntymiselle.

Vuonna 1992 säädetty varallisuusverolaki korvasi entisen lain. Siihen otettiin taide-esineistä säännös (10 \$:n 1 kohta), jonka mukaan tavanomaista arvokkaammat taide-esineet tulivat veronalaisiksi varoiksi. Esimerkiksi Edward Anderssonin teoksessa Tuloverotus ja varallisuusverotus (1995) todettiin asiasta (s. 396) seuraavaa:

Kiistatonta on nyt ainakin, että taidekokoelmat, joilla omistaja käy kauppaa tai joita muulla tavalla käytetään ansiotoiminnassa, esim. vuokraamalla tai näyttämällä niitä voiton saamiseksi, kuuluvat veronalaisiin varoihin. Muissa tapauksissa on ainakin suositeltava varovaisuutta uuden säännöksen soveltamisessa; sekä tiedonsaannissa että arvostuksessa on ongelmia.

\subsubsection{Kiinteistövero}

\subsubsection{Kiinteistöveron historiasta}

Kuten edellä on todettu, nettotuloon perustuva yleinen tuloverotus on verohistoriassa varsin uusi keksintö. Sitä edelsivät mm. kiinteistöjen tuottoverot, joissa vero määräytyi kaavamaisesti kiinteistön arvioidun tuottokyvyn mukaan. Kiinteistöveroa voidaan pitää myös varallisuusveron etäsukulaisena, nimittäin tietyn bruttovarallisuuden verona.

Nykyinen kunnallinen kiinteistöverotus tuli voimaan vuoden 1993 alussa. Sillä korvattiin asuntotulon verotus, kiinteistöjen harkintaverotus, katumaksu ja manttaalimaksu.

Kiinteistövero määräytyy kiinteistön arvon perusteella, ja kunta saa määrätä kiinteistöjen veroprosentit lakisääteisissä rajoissa. Kiinteistön verotusarvo määräytyy varojen arvostamisesta verotuksessa annetun lain mukaan varsin kaavamaisesti. Mikäli jatkossa säädetään hienojakoisempia arviointikriteerejä, alueiden ja rakennusten 
arkkitehtoninenkin arvo saattaa lisätä kiinteistöveroa joissakin kohteissa.

\subsubsection{Yleishyödyllisten yhteisöjen asema kiinteistöverotuksessa}

Kiinteistöllä tarkoitetaan kiinteistöverotuksessa tonttia rakennuksineen. Suoraan laissa on kiinteistöverosta vapautettu tietyt maa-alueet ja rakennukset, mm. autiokirkot ja luostarit. Verovapaiksi ei ole säädetty kiinteistöjä esimerkiksi sillä perusteella, että kysymyksessä olisi rakennustaiteellisesti merkittävä kohde.

Vuonna 1995 kiinteistöverolakiin lisättiin lakialoitteen pohjalta 13 a $\$$. Sen mukaan kunnanvaltuusto sai määrätä maamiesseuran, nuorisoseuran ja työväenyhdistyksen omistaman yhdistys- ja seurantalon kiinteistöveroprosentin normaalia alemmaksi, jos rakennus oli pääasiallisesti yleisessä tai yleishyödyllisessä käytössä; rakennuksen kiinteistöveroprosentiksi voitiin määrätä myös nolla. Lainkohdan soveltamisala laajennettiin valtiovarainvaliokunnan mietinnön pohjalta vuonna 1998 koskemaan kaikkia yleishyödyllisiä yhteisöjä ja myös tontin osalta. Pykälä kuuluu nykyisin seuraavasti:

Poiketen siitä, mitä 11 §:ssä kiinteistöveroprosentin alarajasta säädetään, kunnanvaltuusto voi määrätä tuloverolain 22 \$:ssä tarkoitetun yleishyödyllisen yhteisön omistaman rakennuksen ja sen maapohjan kiinteistöveroprosentin edellä säädettyä alhaisemmaksi, jos kiinteistöllä sijaitseva rakennus on pääasiallisesti yleisessä tai yleishyödyllisessä käytössä. Tässä pykälässä tarkoitetun kiinteistön kiinteistöveroprosentiksi voidaan määrätä myös 0,00 .

Muutamat kunnat eivät ole vahvistaneet yleishyödyllisille yhteisöille normaalia alempaa veroprosenttia, melko ovat monet vahvistaneet alhaisen veroprosentin, mutta suurin osa kunnista on määrännyt yleishyödyllisten yhteisöjen kiinteistöveroprosentin nollaksi. Huojennus koskee myös yleishyödyllisiä taidejärjestöjä. 


\subsection{Tulot ja menot taiteesta}

\subsubsection{Tulojen veronalaisuus ja tulolähde}

Tulot, joita ei ole säädetty verovapaiksi, ovat veronalaisia tuloja. Tuloverotuksessamme tunnetaan kolme tulolähdettä: henkilökohtainen tulolähde, elinkeinotulolähde ja maataloustulolähde. ${ }^{129}$ Henkilökohtaisten tulojen laskennasta säädetään tuloverolaissa, elinkeinotuloista laissa elinkeinotulon verottamisesta ja maataloustulosta saatujen tulojen osalta maatilatalouden tuloverolaissa. Taide kuuluu niin harvoin maatalouteen, että seuraavassa ei käsitellä tarkemmin maatilatalouden tuloverolakia vaan keskitytään tuloverolakiin ja elinkeinoverolakiin. Valinnasta TVL- ja EVL-tulolähteen välillä kirjoitetaan teoksessa Andersson - Gyllström Kuvataiteilijan verotuksesta (1982) s. 15-16 seuraavasti:

Vapaana taiteilijana ammatillisesti toimiva henkilö ei välttämättä ole EVL:n tarkoittama ammatinharjoittaja. Näiden kahden käsitteen erillään pitäminen on hyvin tärkeää, sillä muutoin saatetaan helposti tehdä se väärä johtopäätös, että sellainen vapaa taiteilija, jota ei katsota ammatinharjoittajaksi, aina olisi harrastelija.

Jos saisimme ratkaista kysymyksen välittämättä oikeuskäytännöstä, olisimme epäröimättä sitä mieltä, että taiteilijaa olisi pääsääntöisesti verotettava ns. muusta ansiotoiminnasta TVL:n mukaan, ja että taiteellisen toiminnan olisi oltava varsin laaja, ennen kuin sitä voitaisiin pitää kirjanpitolaissa tarkoitettuna ammattitoimintana, jota verotetaan EVL:n mukaan. Käytännössä EVL:n säännöksiä on kuitenkin yhä enemmän ruvettu soveltamaan kuvataiteilijoihin ja asiaa koskeva ennakkopäätös on olemassa.

KHO on nimittäin ratkaisussa 1977 II 532 katsonut EVL:n sovellettavaksi laiksi, vaikka kyseessä oli henkilö, jolla ko. vuonna ei ollut tuloja taiteellisesta toiminnasta ja joka elätti itsensä kuvaamataidonopettajana. KHO:n kannanotto on ainakin osaksi saattanut perustua siihen, että ao. taiteilija itse oli valituksessaan vedonnut sellaisiin asianhaaroihin, jotka puhuivat EVL:n soveltamisen puolesta. Pidämme kuitenkin tätä KHO:n kantaa ja ennen kaikkea sen julkaisemista onnettomana, sillä ko. tapaus oli juuri sellainen, jossa TVL olisi mielestämme oikea ja paremmin

129 Yleisesti TVL-tulolähteestä ja sen tulon laskemisesta esim. Räbinä-MyllymäkiMyrsky Henkilökohtaisen tulon verotus (2019) ja EVL-tuloista esim. Malmgrén - Myrsky Elinkeinotulon verotus (2020). 
soveltuva laki. Sen sijaan pidämme EVL:n soveltamista täysin aiheellisena ja oikeana sellaisissa tapauksissa, joissa vapaan taiteilijan ammatti on kiistatta verovelvollisen päätulolähde, ja toiminta on sitä paitsi myös taloudellisen tuloksen osalta melko huomattavaa ja tulojen kertyminen verraten säännöllistä.

Niitä kuvataiteilijoita, jotka kuten esim. kuvittajat harjoittavat taidettaan pääasiallisesti työsopimussuhteessa, verotetaan joka tapauksessa ensisijaisesti TVL:n mukaan. Ja tietääksemme tätä lakia sovelletaan käytännössä edelleen sellaisiin vapaisiin taiteilijoihin, joiden toiminta taloudellisessa mielessä on vähäistä. Tuloja taiteen harjoittamisesta on tällöin pidettävä ns. muusta ansiotoiminnasta saatuna tulona.

Poikkeustapauksissa eli silloin, kun "taiteilija" ei ole ammattilainen vaan harrastelija, hänen saamansa myyntitulon voidaan katsoa olevan "muu satunnainen voitto". Näissä harvoissa tapauksissa tulonhankkimismenojen vähentäminen lienee rajoitettua, kohdistuen vain tuon nimenomaisen myyntitulon hankkimismenoihin.

Rajatapauksissa verovelvollisen on syytä antaa itse valita tulolähde, jossa verotus tapahtuu; asia riippuu lähtökohtaisesti siitä, miten eli millä verolomakkeella veroilmoitus on tehty.

\subsubsection{Tulolajit}

\subsubsection{Ansiotulot ja pääomatulot}

Luonnollisen henkilön ja kuolinpesän tulo jaetaan kahteen tulolajiin, jotka ovat pääomatulo ja ansiotulo. Yhteisön ja yhteisetuuden muuhun tuloon kuin elinkeinotuloon ja maatalouden tuloon noudatetaan soveltuvin osin pääomatulon laskemista koskevia säännöksiä.

Luonnollisen henkilön ja kuolinpesän sellaiset tulot, joita ei ole säädetty pääomatuloksi, ovat ansiotuloa. TVL 32 \$:n mukaan pääomatuloa on, siten kuin siitä laissa tarkemmin säädetään, omaisuuden tuotto, omaisuuden luovutuksesta saatu voitto ja muu sellainen tulo, jota varallisuuden voidaan katsoa kerryttäneen. Pääomatuloa on mm. korkotulo, osinkotulo siten kuin laissa tarkemmin säädetään, vuokratulo, voitto-osuus, henkivakuutuksen tuotto, kapitalisaatiosopimuksen tuotto, metsätalouden pääomatulo, maa-aineksista saadut tulot, luovutusvoitto ja osakesäästötililtä nostettu tuotto. Pääomatuloa on myös jaettavan yritystulon ja yhtymän osakkaan tuloosuuden pääomatulo-osuus. 


\subsubsection{Aineettomista oikeuksista saatujen tulojen tulolaji}

Eräistä aineettomiin oikeuksiin perustuvista korvauksista säädetään TVL 52 \$:ssä. Sen mukaan verovelvollisen saama korvaus patentista, tekijänoikeudesta tai muusta niihin verrattavasta oikeudesta on veronalaista pääomatuloa, jos oikeus on saatu perintönä tai testamentilla taikka hankittu vastiketta vastaan; muutoin kysymys on ansiotulosta. Säännös tarkoittaa ensisijaisesti mainitunlaisista oikeuksista saatuja käyttökorvauksia, rojalteja ja vastaavia tuloja. Jos perintönä tai testamentilla saatu tai vastiketta vastaan hankittu aineeton omaisuus myydään, tapaukseen sovelletaan normaaleja luovutusvoiton verotussäännöksiä.

Lahjana saatua samanlaista oikeutta säännös ei koske. Jottei ansiotuloa voitaisi muuntaa pääomatuloksi lahjoittamalla kyseinen oikeus, säännös edellyttää, että lahjana saadun oikeuden tuotto on ansiotuloa. Jos esimerkiksi siirtohinta lähiomaisten välillä on käypää arvoa alhaisempi, katsottaneen saanto osittain vastikkeelliseksi ja osittain lahjaksi ja saatu tekijänoikeus- tms. korvaus verotettaneen osittain ansio- ja osittain pääomatulona.

Jos sitä vastoin aineettoman oikeuden tekijä itse luovuttaa tuon aineettoman oikeuden, katsotaan ansiotuloksi sekä käyttökorvaus (vuokra, rojalti tms.) että luovutushinta, kun luovutetaan omistusoikeus. Tämä johtuu siitä, että saadun edun katsotaan perustuvan asianomaisen tekijän (aivo)työhön.

Käytännöstä mainittakoon KVL 1993:313, jossa verovelvollisen tekemän patentoidun keksinnön hyödyntämisestä saamaa palkkiota pidettiin ansiotulona. Seuraavissa vanhemmissakin oikeustapauksissa oli katsottu, ettei kysymys ollut luovutusvoitosta:

KHO 1965 II 560. Keksijän luovuttamastaan patenttioikeudesta saama korvaus katsottiin veronalaiseksi tuloksi.

KHO 1970 II 512. Säveltäjän myymästään sävellysteoksensa käsikirjoituksesta saama hinta katsottiin säveltäjän veronalaiseksi tuloksi.

KHO 1992 B 515. Taiteilija myi yhdessä perheensä kanssa omistamansa X Oy:n konkurssipesän kanssa nimiinsä rekisteröityyn tavaramerkkiin liittyvät kaikki teollisoikeudet yhteensä 3 miljoonan markan kauppahinnasta. Myyjät jakoivat pankkiin talletetun kauppahinnan ja 
sille kertyneen talletuskoron siten, että taiteilijan osuudeksi tavaramerkin kauppahinnasta tuli 2,5 miljoonaa markkaa. Taiteilijan saama kauppahinta lisättiin hänen tuloihinsa. Valituksessaan taiteilija vaati, että hänen verotettaviin tuloihinsa lisätty tavaramerkin kauppahinta oli poistettava, koska saatuun tuloon tuli soveltaa luovutusvoittosäännöksiä. Valitus hylättiin. Tavaramerkki perustui taiteilijan toimintaan ja hänen taiteelliseen työpanokseensa, joten kauppahinnan koko määrää 2,5 miljoonaa markkaa oli pidettävä hänen veronalaisena tulonaan. Eri mieltä olleet jäsenet katsoivat, että tavaramerkin kauppahintaan voitiin soveltaa luovutusvoittosäännöksiä.

\subsubsection{Verovapaita tuloja}

\subsubsection{Stipendit ja apurahat}

Vuoden 1920 tulo- ja omaisuusverolaissa ei vielä ollut nimenomaisia erityissäännöksiä taiteilijoiden tuloista. Vuonna 1924 säädettyyn tulo- ja omaisuusverolakiin sen sijaan sellainen sisältyi. Lain 11 \$:n 6 kohdan mukaan tuloksi ei nimittäin katsottu "stipendiä tai matkaapurahaa, joka on annettu tieteellisiä tai taiteellisia opintoja tai tieteellisiä tutkimuksia varten”.

Vuonna 1943 säädetyn tulo- ja omaisuusverolain 24 \$:n 15 kohdan mukaan tuloksi ei katsottu stipendiä tai matka-apurahaa, joka oli saatu opintoja tai tutkimusta varten. Rekola totesi kirjassa Tulo- ja omaisuusverolaki (1947, s. 216) asiasta seuraavaa:

Stipendi ja matka-apuraha oli ETOL:n mukaan verovapaa vain silloin, kun se oli annettu tieteellisiä tai taiteellisia opintoja tai tieteellisiä tutkimuksia varten, mutta TOL:n mukaan se on vapautettu verosta aina, kun se on annettu opintoja tai tutkimuksia varten. On näet pidetty kohtuullisena, että myös $\mathrm{mm}$. ammattiopintojen harjoittamista varten myönnetyt stipendit ja matka- ym. apurahat vapautuvat verotuksesta silloinkin, kun sanottuja opintoja ei voida pitää laadultaan suorastaan tieteellisinä tai taiteellisina. Apurahan saajan on vaadittaessa kuitenkin esitettävä selvitys opintojen tai tutkimusten harjoittamisesta, sillä tarkoituksena ei ole ollut vapauttaa verotuksesta tavallisia huvimatkakustannuksia, vaikkakin matka, niin kuin usein tapahtuu, verhottaisiin opintomatkan nimellä. Säännöksen nojalla voitaneen pitää verosta vapaana $\mathrm{mm}$. ulkomaista opintomatkaa varten näyttelijälle myönnetystä lahjanäytännöstä saatua tuloa, jos lahjanäytännön antamisesta ei ole sovittu jo työsuhteen solmiamisen yhteydessä, jolloin tämä tulo saa työpalkan luonteen ja on sen vuoksi veronalaista. 
Säännös säilyi samanlaisena verovuoteen 1974 saakka. Vuodesta 1975 alkaen sovellettiin tulo- ja varallisuusverolakia (31.12.1974/1043). Sen 22.1 \$:n 2 kohdan mukaan veronalaiseksi ei katsottu "stipendiä, opintorahaa tai muuta apurahaa, joka on saatu opintoja tai tieteellistä tutkimusta tai taiteellista toimintaa varten”. Verovapaudelle säädettiin nyt myös enimmäismäärä, joka sidottiin vuodesta 1976 alkaen valtion taiteilija-apurahan vuotuiseen määrään.

Vuoden 1988 tulo- ja varallisuusverolaissa apurahoista säädettiin 64 §:ssä. Säännös oli muutoin aikaisemman kaltainen, mutta siihen sisältyi myös kohta, jonka mukaan veronalaista tuloa ei ollut muu opintoraha kuin opintotukilaissa tarkoitettu aikuisopintorahana saatu ansionmenetyskorvaus. Vuonna 1992 säädetyssä tuloverolaissa apurahoista säädetään 82 \$:ssä. Säännös sinänsä säilyi entisenlaisena, mutta nyt opintotukilain mukaisia etuja koskeva kohta siirrettiin sellaisenaan verovapaita sosiaalietuja koskevaan TVL 92 \$:ään.

Lainmuutoksella 30.12.1993/1502 lisättiin TVL 82 \$:ään 4 momentti, jonka mukaan pykälässä tarkoitettuna apurahana pidetään myös eräistä kirjailijoille ja kääntäjille suoritettavista apurahoista ja avustuksista annetun lain 1 §:ssä tarkoitettua apurahaa ja avustusta. Lainmuutos johtui siitä, että ratkaisussa KHO 1993 B 516 nämä suoritukset oli katsottu veronalaisiksi.

Anderssonin - Linnakankaan - Fränden teoksessa Tuloverotus (2016) todetaan apurahoista mm. seuraavaa (s. 365-367):

Varsinainen apuraha on luonteeltaan vastikkeeton suoritus, joka voidaan antaa hakemuksesta tai hakemuksetta. Vastikkeettomuus ei häviä sillä, että hakija esittää työsuunnitelman, jonka toteutumista apurahan myöntäjä haluaa tukea. On jopa mahdollista, että apuraha julistetaan haettavaksi tiettyyn tarkoitukseen, joka on myöntäjää lähellä. Jos apurahasta tällöin on ollut vapaa kilpailu eikä saaja ole esimerkiksi työmenetelmien suhteen riippuvainen myöntäjästä, voidaan katsoa, että kysymys on apurahasta. Mitä kaupallisempia ovat apurahan myöntäjä ja tarkoitus, johon apuraha myönnetään, sitä lähemmäksi toimeksiantosuhdetta (tilaustyötä) tullaan. Jos saaja on työ-, virka- tai vastaavassa suhteessa maksajaan, voidaan yleensä puhua veronalaisesta lisäpalkkiosta. Sitä vastoin yleishyödyllisten säätiöiden ja muiden vastaavien yhteisöjen myöntämissä apurahoissa on harvemmin tämä piirre. [ - - ]

Opintojen käsite on [ - - ] ymmärrettävä laajana, joten se sisältää tieteelliset ja taiteelliset opinnot, korkeakouluopinnot, ammattikouluopinnot sekä myös eräät kurssimuotoiset opinnot. [ - - ] 
Myös tieteellisen tutkimuksen käsitteen sisältö on tulkittava laajasti. Se ei rajoita tutkimusta millekään tietylle alalle, vaan ratkaisevaa pikemminkin on, joudutaanko tutkimuksessa käyttämään tieteellisiä metodeja. Niinpä on hyväksytty esimerkiksi oikeustieteellisen teoksen laatimista sekä väestöhistoriallista tutkimusta varten annetut stipendit (KHO 1966 II 555 ja KHO 1965 II 555b). [ - - ]

Taiteilijastipendit ovat verovapaita sekä silloin, kun ne on annettu taideopintoja varten, että muissa tapauksissa eli varsinaista taiteellista toimintaa varten. Verovapaina taiteilijastipendeinä voidaan pitää myös valtion ja muiden julkisyhteisöjen antamia märäaikaisia elatusstipendejä. Kertasummana myönnetyt taiteilijastipendit luonnollisesti ovat verovapaita.

\subsubsection{Tunnustuspalkinnot}

Vuonna 1943 säädetyn tulo- ja omaisuusverolain 24 \$:n 15 kohdan mukaan tuloksi ei katsottu "tieteellisen tai taiteellisen toiminnan tunnustukseksi annettua palkintoa". Teoksessaan Tulo- ja omaisuusverolaki (1947, s. 216-217) Rekola kommentoi säännöstä seuraavasti:

[ - - ] on katsottu kohtuulliseksi, että tieteellisen tai taiteellisen toiminnan tunnustukseksi annetut palkkiot jätetään verottamatta. Tällaisia palkkioita tai palkintoja ovat, paitsi esim. Nobelin-palkintoa, mm. erinäisten sivistysrahastojen ja -järjestöjen tiedemiehille ja taiteilijoille antamat palkinnot, joiden verovapaudesta aikaisemmin ei ollut olemassa säännöstä, mutta tuskin ns. taiteilijaeläkkeet [ - - ]. Sana taiteellinen on tässä yhteydessä tulkittava niin laajasti, että säännös koskee myös kirjallisen toiminnan tunnustukseksi annettua palkkiota, joten sitäkin on pidettävä verovapaana.

Vuosittain annetuissa laeissa eräistä väliaikaisista poikkeussäännöksistä verolakeihin säädettiin 1950-luvun alusta lukien verovapaiksi tieteellisen ja taiteellisen toiminnan tunnustukseksi annettujen palkkioiden lisäksi samanluonteinen valtion antama taiteilijan eläke. Myöhemmin 1950-luvulla tuo eläkkeen verovapautta koskeva kohta laajennettiin koskemaan valtion muustakin ansiokkaasta toiminnasta antamaa eläkettä. ${ }^{130}$ Vuonna 1967 poikkeussäännöksiin lisättiin verovapaana tulona myös kansainvälinen rauhanpalkinto (L 20.6.1967/306).

130 Sittemmin tällaiset eläkkeet säilyivät verovapaina vain, jos ne oli myönnetty ennen vuotta 1984. 
Tulo- ja varallisuusverolaissa (31.12.1974/1043) veronalaisten tunnustuspalkintojen piiri laajeni, kun verovapaiksi 22.1 \$:n 2 kohdassa säädettiin tieteellisen tai taiteellisen toiminnan tunnustukseksi annetun palkinnon lisäksi yleishyödyllisestä toiminnasta tunnustukseksi annettu palkinto. Toisaalta nyt apurahojen ja tunnustuspalkintojen verovapaudelle säädettiin yhteiseksi ylärajaksi valtion taiteilija-apurahan vuotuinen määrä, ja julkisyhteisöiltä saaduilla suorituksilla oli erityisasema. Laissa kuitenkin annettiin valtiovarainministeriölle oikeus hakemuksesta päättää, että tieteellisen, taiteellisen tai yleishyödyllisen toiminnan tunnustukseksi annettu palkinto oli koko määrältään verosta vapaata tuloa. Mahdollisuus päättää koko palkinnon määrä verovapaaksi on tarkoitettu sovellettavaksi ennen kaikkea suuriin ja kansainvälisesti tunnustettuihin palkintoihin (esim. Nobelja Anders Jahre -palkinnot). Niiden kohdalla herättäisi kiusallista huomiota, jos Suomen valtio ja kunnat veisivät verona valtaosan suuresta tunnustuspalkinnosta.

Vuoden 1993 alusta voimaan tulleessa tuloverolaissa tunnustuspalkinnoista säädetään 82 \$:ssä, joka on entisen kaltainen. Teoksessa Andersson - Linnakangas - Frände Tuloverotus (2016, s. 368-369) todetaan verovapaista tunnustuspalkinnoista $\mathrm{mm}$. seuraavaa:

Palkinto annetaan tunnustukseksi joko jostakin teosta (esim. keksinnöstä, kirjan julkaisemisesta, olympiamitalin saamisesta tai ihmishenkien pelastamisesta) tai asianomaisen henkilön kokonaistoiminnasta, esimerkiksi pitkäaikaisesta toiminnasta jonkin taiteen alan edustajana. Yleensä palkinnon antamiseen liittyy myös jonkin verran julkisuutta.

Toiminta voinee olla joko maamme sisäistä tai kohdistua ulkomaihin, esimerkiksi kehitysmaiden olojen parantamiseen. Palkinto voi olla myös ulkomailta saatu. Tärkeämpää on, että palkinnon saajan toiminta on ollut epäitsekästä, jolla ei tarkoiteta, että saajan olisi täytynyt toimia palkatta. Jos palkinto kuitenkin on vain eräänlainen jälkikäteispalkkio tehdystä työstä, sitä ei voida pitää verovapaana. Palkinnosta ei yleensä voine olla kysymys, jos antajana on saajan (nykyinen tai entinen) työnantaja.

Verovapaana tunnustuspalkintona ei pidetä palkintoa, jonka esimerkiksi arkkitehti tai muu suunnittelija voittaa suunnittelukilpailussa (esim. KHO 1952 II 763). Kilpailujen on näillä aloilla katsottu liittyvän läheisesti normaaliin työskentelyyn, eivätkä palkinnot ole tässä käsiteltyjä tunnustuspalkintoja. Mitä taas tulee tapauksiin, joissa esimerkiksi kaunokirjallisesta toiminnasta annettavat palkinnot jaetaan vain tietyn kustannusyrityksen piirissä toimineille kirjailijoille, niiden verovapaus on varsin 
kyseenalainen, joskin se on aiemmin hyväksytty käytännössä (KHO 1961 T 602). Urheilusuorituksista tunnustuksena annetut rahapalkinnot eivät voine yleensä saada verovapautta (KHO 1986 II 549, "vuoden avainpelaaja"). Poikkeuksen muodostanevat kuitenkin todella huomattavasta urheilusaavutuksesta (esim. olympiavoitto) myönnetyt tunnustukset.

Selvästi lähinnä kaupallisiin tarkoituksiin myönnetyt "palkinnot" eivät voi olla verovapaita. Esimerkkeinä oikeuskäytännöstä mainittakoon visailukilpailuissa saatu palkinto (KHO 1986 T 4724), kunnan matkailun ideakilpailun palkinto (KHO 1988 B 538), suuryrityksen myöntämä tuotekehityspalkinto (KHO 1989 B 522) ja perunanjalostuksesta myönnetty tunnustuspalkinto (KVL 1989:279). Toisinaan on myös presumtiivisten saajien piiri niin suppea, ettei palkintoa voida pitää verovapaaksi tarkoitettuna.

\subsubsection{Kilpailupalkinnot}

Anderssonin - Gyllströmin kirjassa Kuvataitelijan verotuksesta (1982, s. 70) todettiin, että valtion taidekilpailussa myönnettyjen palkintojen suhteen oli olemassa KHO:n päätös 22.2.1965 N:o 749, jonka mukaan tällainen palkinto katsottiin verovapaaksi tunnustuspalkinnoksi.

Nykyisin taidekilpailupalkinnoista säädetään TVL 83 §:ssä. Sen mukaan veronalaista tuloa ei ole taiteen alalla järjestetystä, taiteellisesti merkittävästä valtakunnallisesta tai kansainvälisestä valtiovarainministeriön nimeämästä kilpailusta saatu palkinto. Valtiovarainministeriö nimeää opetusministeriön esityksestä tässä tarkoitetut kilpailut vuosittain etukäteen ennen kilpailuvuoden alkamista. Teoksessa Andersson - Linnakangas - Frände Tuloverotus (2016, s. 369-370) todetaan taidekilpailupalkinnoista mm. näin:

Tunnustuspalkintojen lisäksi on olemassa myös kilpailupalkintoja, lähinnä taiteen alalla. Näiden palkintojen verotuksellinen asema ei ollut TVL:n alkuperäisen sanamuodon mukaan aivan selvä. Oikeuskäytännössä oli tosin katsottu (KHO 1980 II 614), että nuorille viulunsoittajille järjestetyssä kilpailussa saatu palkinto oli tunnustuspalkinnon luonteisena verovapaa. Nykyisin TVL 83 \$:n säännös koskee taidekilpailupalkintoja (erotukseksi tunnustuspalkinnoista). Sen mukaan veronalaisena tulona ei pidetä taiteen alalla järjestetystä, taiteellisesti merkittävästä valtakunnallisesta tai kansainvälisestä kilpailusta saatua palkintoa. Valtiovarainministeriö nimeää vuosittain etukäteen opetusministeriön esityksestä ne taiteen alan kilpailut, joita voidaan pitää edellä tarkoitetussa mielessä 
merkittävinä. [ - - ] Merkittäviksi katsottavien kilpailujen kynnys ei näy olevan kovin korkea.

Koululaiskilpailupalkintoja koskee TVL $84 \$$. Sen mukaan veronalaista tuloa ei ole peruskoulun, lukion, iltalukion, ammattikoulun tai muun näihin verrattavan oppilaitoksen oppilaiden tieto- tai taitoaineessa järjestetystä kilpailusta muuna kuin rahana tai siihen verrattavana suorituksena saama palkinto. Teoksessa Andersson - Linnakangas - Frände Tuloverotus (2016, s. 370) todetaan koululaiskilpailupalkinnoista, että säännös ei tunnu kovin tarpeelliselta; samaan tulokseen olisi pitänyt päästä jo lain järkevällä tulkinnalla.

Muista kuin 83 ja 84 \$:ssä tarkoitetuista kilpailupalkinnoista sää-

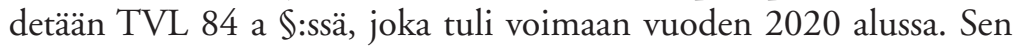
mukaan sellainen kilpailupalkinto ei ole veronalaista tuloa, jos sitä ei voida pitää ennakkoperintälaissa tarkoitettuna palkkana taikka työ- tai käyttökorvauksena ja jos verovelvollisen verovuonna saamien kilpailupalkintojen arvo on yhteensä enintään 100 euroa. Tämä lainmuutos perustuu valtiovarainvaliokunnan mietintöön 16/2019, jossa säännöstä perusteltiin seuraavasti:

Kilpailupalkintojen ilmoittamismenettelyn ja -rytmin muuttumisen on koettu aiheuttavan urheiluseuroissa ja erilaisessa harrastustoiminnassa merkittävää hallinnollista lisävaivaa aiemmin vallinneeseen tilanteeseen verrattuna. Esityksessä on ehdotettu, että pienet kilpailupalkinnot rajattaisiin tulorekisterin ilmoittamisvelvollisuuden ulkopuolelle. Kilpailun järjestäjä ei ilmoittaisi jatkossa enintään 100 euron arvoista raha- tai tavarapalkintoa rekisteriin Verohallinnolle välitettäväksi. Muutos tarkoittaisi käytännössä sitä, että kilpailupalkinnon saajan tulisi itse ilmoittaa saamansa enintään 100 euron arvoinen kilpailupalkinto omassa veroilmoituksessa.

Asiantuntijakuulemisessa tätä muutosta ei pidetty tarkoituksenmukaisena. Ehdotetussa sääntelyssä ilmoittamisvelvollisuus siirtyy kilpailun järjestäjältä usealle eri henkilölle itselleen, mitä on pidetty ongelmallisena verotuksen tehokkuusperiaatteen valossa. Yhden ilmoituksen sijaan Verohallinto saisi useita ilmoituksia eri tahoilta.

Ilmoittamismenettelyä on pidetty tehokkuusperiaatteen valossa ongelmallisena myös sen johdosta, että vähäisiin kilpailupalkintoihin sisältyy tulonhankkimiskuluja, joiden selvittäminen ja verovalvonta on hankalaa ja tarpeettoman raskasta huomioiden palkinnon arvo. Täten verotettavan tulon määrää voidaan vähennysten jälkeen pitää erittäin vähäisenä alle 
100 euron arvoisissa kilpailupalkinnoissa. On myös oletettavaa, että tällainen vähäinen kilpailupalkinto jää verotuksen ulkopuolelle tahattoman ilmoituspuutteen vuoksi. Verohallinnon resurssien kohdentamista tällaisten ilmoituspuutteiden valvontaan ei voida pitää tarkoituksenmukaisena.

Näiden syiden johdosta valiokunta ehdottaa, että kilpailusta saadut enintään 100 euron arvoiset raha- ja tavarapalkinnot ovat tietyissä tilanteissa saajalleen verovapaata tuloa. Muutosehdotuksella ei arvioida olevan vaikutusta verotuottoihin, kun huomioidaan ehdotettu euroraja ja tuloon kohdistuvat tulonhankkimiskulut sekä palkintojen rajallinen lukumäärä.

Valiokunta ehdottaa, että kilpailusta saadut enintään 100 euron arvoiset raha- ja tavarapalkinnot ovat saajalleen verovapaata tuloa, kun se ei ole ennakkoperintälaissa tarkoitettua palkkaa, työ- tai käyttökorvausta. Tuloa voitaisiin pitää verovapaana, jos verovuonna saatujen kilpailupalkintojen arvo on yhteensä enintään 100 euroa. Säännös tarkoittaisi käytännössä sitä, että kilpailupalkintojen arvon ylittäessä verovuonna 100 euroa palkinto olisi kokonaisuudessaan saajalleen veronalaista tuloa. Näin esimerkiksi 500 euron arvoinen kilpailupalkinto olisi saajalleen verotettavaa tuloa koko määrästä eikä vain 100 euroa ylittävältä osalta.

\subsubsection{Taide verovapaana henkilökuntaetuna}

Vielä 1940-luvulla verovapaista henkilökuntaeduista ei ollut laissa nimenomaisia säännöksiä, eikä niistä ollut juuri oikeuskäytäntöäkään. 1950-luvulta alkaen KHO julkaisi runsaasti ratkaisuja henkilökuntaetujen verotuskohtelusta. Ratkaisut koskivat terveydenhoitoetuja, merkkipäivälahjoja ja henkilökunta-alennuksia.

Vuonna 1983 säädetyllä lainmuutoksella tulo- ja varallisuusverolakiin lisättiin säännös tavanomaisten henkilökuntaetujen verovapaudesta. Lainmuutoksen välittömänä syynä oli löytää Finnairia tyydyttävä ratkaisu työntekijöiden ilmais- ja alennusmatkoja koskevassa kiistassa ja siten estää lakot lentoliikenteessä. Verovapaiksi säädettiin tässä yhteydessä eräiden muiden etujen lisäksi myös tavanomainen ja kohtuullinen etu työnantajan järjestämästä virkistys- ja harrastustoiminnasta.

Vuonna 2003 verovapaisiin henkilökuntaetuihin lisättiin liikuntasetelit. Vuonna 2008 tehdyllä lainmuutoksella verovapaiden henkilökuntaetujen piiriin otettiin myös kulttuurisetelit. Vuonna 2021 verovapaus laajennettiin kulttuuritapahtumien etäosallistumiseen. Tätä perusteltiin hallituksen esityksessä 63/2021 seuraavasti: 
Koronaviruksen aiheuttamien rajoitusten johdosta on herännyt kysymyksiä siitä, voiko liikunta- ja kulttuurietua käyttää myös erilaisiin etäyhteyden avulla järjestettäviin tilaisuuksiin. Aihetta koskevan Verohallinnon ohjeen mukaan erilaista ohjattua liikuntaa voidaan järjestää myös etäyhteyttä hyödyntäen, joten liikunnan osalta etua voidaan käyttää etäyhteyden avulla järjestettyyn liikuntatoimintaan. Kulttuuriedun osalta säännöstä on verotuskäytännössä tulkittu sen sanamuodon mukaisesti siten, että edun käyttäminen edellyttää fyysistä käyntiä säännöksessä tarkoitetuissa paikoissa, tilaisuuksissa tai tapahtumissa. Kulttuurietua ei siten ole voinut käyttää esimerkiksi livestriimattujen kulttuuritapahtumien osallistumismaksuihin. Nykypäivänä ja etenkin koronaviruksen aiheuttamien rajoitusten johdosta erilaiset virtuaalisesti järjestettävät kulttuuritapahtumat ovat kuitenkin lisääntyneet, joten kulttuuritapahtumien etäosallistumisen mahdollistamista on arvioitu uudelleen.

[- - ]

Tuloverolain (1535/1992) 69 \$:ssä säädetään verovapaista henkilökuntaeduista. Kyse on tavanomaisista ja kohtuullisista työnantajan järjestämistä eduista, joita ei luonteeltaan pidetä työstä, tehtävästä tai palveluksesta saatuna vastikkeena. Pykälän 1 momentin 4 kohdan mukaan työnantajan järjestämä tavanomainen ja kohtuullinen, koko henkilökunnalle suunnattu virkistys- ja harrastustoiminta on verovapaa henkilökuntaetu. Kyse on työnantajan etua silmällä pitäen toteutettavasta, koko henkilöstön viihtyvyyttä ja suorituskykyä tai työpaikan ihmissuhteita ylläpitävästä ja parantavasta toiminnasta, jolla ei ole mainittavaa henkilökunnan elantokustannuksia säästävää vaikutusta.

Tuloverolain 69 §:n 5 momentin mukaan työnantajan järjestämänä verovapaana virkistys- ja harrastustoimintana pidetään myös enintään 400 euron vuosittaista etua työnantajan tarjoamasta työntekijän omaehtoisesta liikunta- tai kulttuuritoiminnasta. Etua on tarjottava koko henkilökunnalle ja se saa olla ainoastaan työntekijän käytettävissä.

Työntekijän omaehtoisella toiminnalla tarkoitetaan sitä, että työntekijä voi harrastaa itse valitsemanaan ajankohtana ja valita harrastuspaikan sekä -tavan useiden eri vaihtoehtojen joukosta. Omaehtoista liikunta- tai kulttuuritoimintaa voi tarjota käyttämällä niin sanottua kohdennettua maksuvälinettä, kuten seteliä tai muuta vastaavaa maksujärjestelmää.

Lainkohdassa ei ole määritelty liikunnan käsitettä. Verohallinnon ohjeen Henkilökuntaedut verotuksessa (VH/8505/00.01.00/2020) mukaan liikunnalla tarkoitetaan henkilön fyysistä aktiivisuutta, jonka tarkoituksena on yleensä kohottaa kuntoa tai ylläpitää taikka parantaa työntekijän fyysistä hyvinvointia ja terveyttä. Sen sijaan kulttuuritoiminta on määritelty tuloverolain 69 \$:n 5 momentissa. Lainkohdan mukaan kulttuuritoiminnalla tarkoitetaan käyntiä museossa, teatterissa, oopperassa, elokuvateatterissa, konsertissa, taidenäyttelyssä tai muussa vastaavassa eri taiteenaloihin liittyvässä tapahtumassa tai tilaisuudessa. 
Kulttuuritoimintana pidetään myös käyntiä tiedekeskuksessa ja urheilutapahtumassa sekä osallistumista ohjatulle toiminnalliselle taidekurssille.

[- - ]

Esityksessä ehdotetaan muutettavaksi tavanomaista henkilökuntaetua koskevan tuloverolain 69 \$:n 5 momenttia siten, että säännöksessä tarkoitettuna kulttuuritoimintana pidettäisiin myös etäyhteyden avulla tapahtuvaa reaaliaikaista osallistumista säännöksessä tarkoitettuun toimintaan.

Kulttuurietua voisi siten käyttää maksuvälineenä myös erilaisissa reaaliaikaisesti järjestettävissä virtuaalisissa kulttuuritapahtumissa ja -tilaisuuksissa. Säännöksen piiriin kuuluisivat siten esimerkiksi reaaliaikaisesti verkossa lähetettävät konsertit, teatteri- ja oopperaesitykset sekä muut vastaavat eri taiteenaloihin liittyvät virtuaalisesti järjestetyt tapahtumat ja tilaisuudet. Kyse tulisi olla nimenomaan reaaliajassa järjestettävästä tapahtumasta tai tilaisuudesta. Reaaliajassa järjestettävällä tapahtumalla tai tilaisuudella tarkoitettaisiin tässä yhteydessä tiettyyn ajankohtaan sidottua kulttuuritapahtumaa tai tilaisuutta. Lähtökohtaisesti kyse olisi tilaisuuksista, jossa todellinen esitys on käynnissä tapahtumapaikalla samaan aikaan kuin se esitetään yleisölle reaaliaikaisesti verkossa. Reaaliajassa tapahtuvana tilaisuutena tai tapahtumana pidettäisiin kuitenkin myös sellaisia tiettyyn ajankohtaan sidottuja tilaisuuksia tai tapahtumia, joissa esitetään esimerkiksi tiettyjä elokuvia, tallenteina esitettäviä teatteriesityksiä, konsertteja tai muita vastaavia kulttuurialan esityksiä tiettynä rajoitettuna ajankohtana. Kulttuurietua voisi siten käyttää niin sanottujen livestriimattavien tapahtumien ohella myös tallennettujen esitysten katselemiseen, jos kyse olisi tiettyyn ajankohtaan sidotusta järjestetystä tapahtumasta tai tilaisuudesta. Tämän tyyppisiä tapahtumia ovat esimerkiksi elokuvafestivaalit, joissa esitetään tiettyjä elokuvia tiettynä ajankohtana, ja tietyn ajan avoinna olevat taidenäyttelyt. Myös esimerkiksi yksittäisen elokuvan taikka tallennetun konsertin tai -teatteriesityksen esittäminen tiettynä päivänä ja tiettyyn kellonaikaan olisi reaaliajassa järjestettävä kulttuuritapahtuma, johon myytävään lippuun voisi käyttää kulttuurietua.

Myös esimerkiksi katseluoikeuden reaaliaikaisesti verkossa esitettävään urheilutapahtumaan voisi hankkia kulttuuriedulla. Reaaliaikaisena urheilutapahtumana pidettäisiin esimerkiksi yksittäisen livestriimatun ottelun tai esimerkiksi jonkin lajin maailmanmestaruuskilpailujen reaaliaikaisen katseluoikeuden hankkimista. Kulttuurietua voi käyttää myös esimerkiksi kausi- ja sarjalippujen hankintaan. Kulttuuriedulla voisi siten vastaavalla tavalla hankkia katseluoikeuden kerralla useampaan virtuaaliseen tapahtumaan (sarjaliput) tai esimerkiksi tietyn joukkueen tai orkesterin koko kauteen (kausikortti). Esimerkiksi oikeus seurata kuukausimaksullisen suoratoistopalvelun kautta tiettyä palloilusarjaa ei kuitenkaan olisi tässä tarkoitettu reaaliaikainen urheilutapahtuma. Vastaavasti kuin edellä mainittujen eri taiteenalojen tapahtumien kohdalla, myös urheilutapahtuman 
esitys voisi olla tallenne, jos kyse olisi tiettyyn ajankohtaan sidotusta järjestetystä tapahtumasta tai tilaisuudesta.

Pelkkien edellä mainittujen tilaisuuksien tallenteiden hankkiminen jälkikäteen ei olisi mahdollista kulttuuriedulla. Pelkän tallenteen hankkiminen tapahtuman jälkeen ei ole tapahtumaan osallistumista. Myöskään elokuvien vuokraaminen ei edelleenkään olisi säännöksessä tarkoitettua kulttuuritoimintaa. Jos kuitenkin esimerkiksi reaaliaikaisesti verkossa lähetettävään konserttiin hankittu lippu tai tiettynä ajankohtana tallenteena esitettyyn näytökseen hankittu lippu oikeuttaa katsomaan saman tapahtuman myös tallenteena jälkikäteen rajoitetun ajan, ei tämä estäisi kulttuuriedun käyttämistä kyseiseen tapahtumaan.

Tapahtuman tai tilaisuuden kestolla ei olisi merkitystä eli kyse voisi olla esimerkiksi tiettyyn ajankohtaan sidotusta useamman päivän kestävästä kulttuuri- tai urheilutapahtumasta. Kyse voisi siten olla esimerkiksi kolmen päivän musiikkifestivaalista, joka sisältää kunakin päivänä usean konsertin.

Kuukausimaksulliset tai muuhun vastaavaan aikaan perustuvaan maksuun sidotut tilaussopimukseen perustuvat palvelut, joiden kautta on mahdollista seurata esimerkiksi elokuvia, urheilua tai konsertteja, eivät kuuluisi edun piiriin. Tämän tyyppisissä palveluissa ei ole kyse kulttuuritapahtumaan tai tilaisuuteen osallistumisesta. Nämä suoratoistopalvelut eivät kuuluisi edun piiriin, vaikka ne sisältäisivät tilaisuuksia tai tapahtumia, joihin hankittava lippu edellä mainitulla tavalla kuuluisi edun piiriin.

Myös säännöksessä tarkoitetulle toiminnalliselle taidekurssille voisi osallistua reaaliaikaisen etäyhteyden avulla. Reaaliaikaisella osallistumisella tarkoitettaisiin tässä yhteydessä sitä, että kurssi sisältäisi suorana verkossa lähetettäviä luentoja tai muuta vastaavaa opetusta. Säännöksen soveltumista ei kuitenkaan estäisi se, että kurssiin kuuluva suorana lähetetty opetus samalla tallennettaisiin ja se olisi katsottavissa myös jälkikäteen.

Säännöksessä tarkoitettuna kulttuuritoimintana pidetään myös käyntiä museossa, taidenäyttelyssä tai muussa vastaavassa paikassa sekä käyntiä tiedekeskuksessa. Näiden osalta etäyhteyden avulla tapahtuvalla reaaliaikaisella osallistumisella tarkoitettaisiin kyseisessä paikassa parhaillaan esillä olevaan näyttelyyn tai kokoelmaan tutustumista. Näin ollen esimerkiksi museoiden tai taidekeskusten kokoelmiin ja näyttelyihin tutustuminen virtuaalisesti olisi edun piirissä.

Edellytyksenä olisi edelleen, että säännöksessä tarkoitettu liikunta- tai kulttuurietu on ainoastaan työntekijän käytettävissä. Edun käyttämiseen oikeuttavien lippujen, seteleiden tai muiden maksujärjestelyjen on näin ollen oltava henkilökohtaisia. Etäpalveluiden luonne huomioiden etäyhteyden avulla toteutettavan osallistumisen kohdalla säännöksen soveltumista ei kuitenkaan estäisi se, että myös muiden henkilöiden on mahdollista seurata tapahtumaa esimerkiksi samalta kuvaruudulta. 
Liikunta- ja kulttuurietua ei kuitenkaan voisi käyttää muiden henkilöiden kuin työntekijän oman maksuosuuden suorittamiseen.

Kulttuurietua voisi käyttää ainoastaan lipun tai osallistumismaksun maksamiseen. Sitä ei voisi käyttää esityksen seuraamiseksi tarvittavien laitteiden ja tarvikkeiden, kuten televisiovastaanottimen tai virtuaalilasien hankintaan tai vuokraamiseen, eikä myöskään tietoliikenneyhteyden järjestämiseen.

\subsubsection{Elokuvatuotantotuki}

Laissa eräistä väliaikaisista poikkeussäännöksistä verolakeihin oli ensi kerran vuonna 1975 kohta, jonka mukaan veronalaista tuloa ei ollut kotimaiselle elokuvan tuottajalle valtion varoista myönnetty tuotantotuki. Kysymys oli kulttuuripoliittisesta verotuesta. Koska kotimaisen elokuvan tuotantotukijärjestelmä oli luonteeltaan pysyvä ja vakiintunut, sen verovapautta koskeva säännös siirrettiin vuodesta 1984 alkaen EVL 6 \$:ään.

Hallituksen esityksessä (HE 122/2014) todettiin, että tukea oli vuonna 2013 maksettu yhteensä noin 20 miljoonaa euroa ja tuen saajia oli 438. Osana julkisen talouden sopeutustoimia pääministeri Jyrki Kataisen hallitus oli päättänyt kevään 2014 kehyspäätöksen yhteydessä, että elokuvatuottajien tuotantotuen verovapaus poistetaan. Tämän vuoksi EVL 6 §:n 1 momentin 5 kohta ehdotettiin kumottavaksi. Kotimaiselle elokuvatuottajalle valtion tai Suomen elokuvasäätiön varoista myönnetty tuotantotuki olisi ollut jatkossa muiden elinkeinotoiminnan tulojen tavoin kokonaan veronalaista tuloa. Muutoshanke liittyi veropohjan laajentamiseen ja elinkeinotukien verokohtelun yhtenäistämiseen.

Valtiovarainvaliokunta ei puoltanut esitystä, ja lakia ei muutettu. Mietinnössä VaVM 25/2014 todettiin, että verovapauden poistoa perusteltiin tavoitteella laajentaa veropohjaa yritystukia karsimalla; lisäksi se oli osa julkisen talouden sopeutustoimia. Näillä näkökohdilla ei ollut kuitenkaan olennaista merkitystä, koska muutoksen verotuottovaikutukseksi oli arvioitu 4 miljoonaa euroa vuositasolla. Tämäkin tuotto oli kyseenalaistettu valiokunnan asiantuntijakuulemisessa, jossa niin opetus- ja kulttuuriministeriö kuin alan toimijatkin olivat puoltaneet verovapautta tuotantokohtaisena projektitukena. Ala oli myös yleisesti ottaen sangen tappiollinen, joten verovapauden 
poisto pienentäisi pääasiassa vain tuotantoyhtiöille vahvistettavia tappioita eikä sillä ei siten olisi välitöntä vaikutusta valtion verotuloihin. Valiokunta otti lisäksi huomioon, että verotuki rajoittui Suomessa verotettavaan elinkeinotoiminnan tuloon. Koska ulkomaisen tuotannon tulos verotetaan yleensä aina muualla kuin Suomessa, säännöstä ei jouduttaisi käytännössä soveltamaan mahdollisiin ulkomaisiin tuensaajiin. Sen vuoksi verotuki itsessään ei muodostaisi valiokunnan käsityksen mukaan sellaista kilpailunvääristymää, joka pitäisi ottaa sääntelyssä huomioon.

Lainmuutoksella 24.4.2015/456 EVL 6.1:n säännöstä muutettiin. Säännöksen uudessa muodossa veronalaista tuloa ei ole Euroopan talousalueella asuvalle elokuvatuottajalle valtion tai Suomen elokuvasäätiön varoista myönnetty tuotantotuki. Verovapautta ei siis enää ole muodollisesti rajoitettu suomalaisiin elokuvatuottajiin.

\subsubsection{Taiteilijan tulonhankkimismenojen vähennyskelpoisuus}

Taiteenharjoittajien vähennyskelpoisista menoista oli erityismaininta jo vuonna 1924 säädetyn tulo- ja omaisuusverolain 12 \$:n 4 kohdassa. Sen mukaan tulon hankkimisesta johtuneeksi vähennyskelpoiseksi kustannukseksi katsottiin myös taiteen harjoittamisesta johtuneet kustannukset. Vuonna 1943 säädetyn tulo- ja omaisuusverolaissa 26.1 \$:n 9 kohdan mukaan vähennyskelpoisina kustannuksina mainittiin taiteen harjoittamisesta johtuneet kohtuullisiksi katsottavat kustannukset, mikäli niitä ei ollut suoritettu verovapaalla stipendillä tai matka-apurahalla. Uutta oli maininta kustannusten kohtuullisuudesta.

Aarne Rekola kommentoi tätä säännöstä vuonna 1947 julkaistussa kirjassaan Tulo- ja omaisuusverolaki (s. 259) näin:

Näillä kustannuksilla tarkoitettaneen mm. sellaisia menoja, kuin esim. ovat näyttelijöiden pukukustannukset ja soittajien instrumenttimenot [ - - ]. Soittajien nuotteja voitaneen pitää heidän "ammattikirjallisuutenaan". Muillakin taiteilijoilla täytyy olla oikeus tehdä vastaavantapaiset vähennykset. Kuvanveistäjän täytyy saada poistaa meisseliensä ja muiden sellaisten työvälineittensä sekä käyttämänsä materiaalin arvot ja taidemaalarin värinsä, kankaansa jne. 
Säännös säilyi samanlaisena myös vuonna 1974 säädetyssä tulo- ja varallisuusverolaissa (26.1 \$:n 6 kohta). Vuonna 1988 säädetyssä tuloja varallisuusverolaissa poistettiin vaatimus kustannusten kohtuullisuudesta. Aikaisemmin laissa olleesta kohtuullisuusvaatimuksesta todettiin kirjassa Andersson - Gyllström Kuvataiteilijan verotuksesta (1982, s. 39 ss.) mm. seuraavaa:

Kohtuullisuus on aina suhteellinen käsite. Mikään ei voi olla kohtuullista sinänsä vaan ainoastaan suhteessa johonkin muuhun, esim. yleisesti vallitseviin olosuhteisiin. Kun on kysymys taiteen harjoittamisesta aiheutuneiden menojen kohtuullisuudesta, voidaan kysyä, onko sitä harkittava ottaen huomioon taiteellisen toiminnan taloudellinen tulos, taiteellinen työ sinänsä vai muiden verovelvollisten olosuhteet.

Vaikuttaa siltä kuin veroviranomaiset melko yleisesti olisivat omaksuneet sen kannan, että tulonhankkimismenojen kohtuullinen määrä on riippuvainen toiminnan taloudellisesta tuloksesta. Onko tällainen tulkinta sitten oikea ja onko sen tulos kohtuullinen? - Vastaamme molempiin kysymyksiin ehdottoman kieltävästi. Menettelyllä ei ole mitään tukea laissa. Lainkohtaa ei saa tulkita niin, että taiteilijoita verotetaan muita ammattiryhmiä huomattavasti ankarammin siten, että normaaleja tulonhankkimismenoja ei hyväksytä vähennykseksi. Mitään sellaista lainsäätäjä ei ole voinut tarkoittaa; se olisi kai jo perustuslain vastaista.

Yleisesti voitaisiin ehkä sanoa, että kohtuullisuusrajoitus lienee tullut lakitekstiin lähinnä harrastelijoita silmällä pitäen. Henkilö, joka harrastaa taidetta huvikseen ja ehkä sattumalta myy muutaman teoksen, saa vähentää ne menot, joiden kohtuudella voidaan katsoa liittyvän myytyihin teoksiin. Hänhän ei tavallisesti ole pitänyt mitään kirjaa kuluistaan mutta on kuitenkin velvollinen veroilmoituksensa yhteydessä selvittämään teostensa myynnistä saamansa tulot.

Ammattitaiteilijankin tulonhankkimismenon vähentämistä voidaan rajoittaa poikkeustapauksissa, esim. kun kysymys on menoista, jotka osittain kuuluvat elinkustannuksiin.

Uudessa tulo- ja varallisuusverolaissa oli maininta vain taiteen harjoittamisesta johtuneista menoista (82.1 \$:n 4 kohta), siis ilman kohtuusvaatimusta. Säännös on tällainen myös vuonna 1993 säädetyn tuloverolain 31.1 \$:n 4 kohdassa, jonka mukaan tulonhankkimisesta johtuneita menoja ovat mm. "ammattikirjallisuuden sekä tutkimusvälineiden ja tieteellisen kirjallisuuden hankkimisesta sekä tieteellisestä työstä ja taiteen harjoittamisesta muutoin johtuneet menot, jos 
niitä ei ole suoritettu $81 \S: n 1$ momentin 1 kohdassa tarkoitetulla stipendillä tai apurahalla”.

Verovelvollisella on oikeus vähentää tuloistaan niiden hankkimisesta ja säilyttämisestä johtuneet menot eli luonnolliset vähennykset (esim. TVL 29 \$). Lähtökohtaisesti verovelvollisen kaikki vakaassa tulonhankkimistarkoituksessa suorittamat menot ovat vähennyskelpoisia (ns. subjektiivinen arviointitapa).

Tulonhankkimismenojen ja vähennyskelvottomien elantomenojen välistä rajaa joudutaan selvittämään $\mathrm{mm}$. työhuonekulujen osalta. Ongelmaa kuvataan kirjassa Andersson - Gyllström Kuvataiteilijan verotuksesta (1982, s. 24 ss.) seuraavasti:

Työhuoneen välttämätön tarve on joka kuvataiteilijalle itsestään selvä asia, ja tällaisen huoneen hankkimiseksi hän on yleensä valmis suuriin taloudellisiin uhrauksiin. Käytäntö on kuitenkin osoittanut, että veroviranomaiset yleisesti suhtautuvat sangen penseästi tähän tarpeeseen. Suhtautuminen johtuu todennäköisesti siitä, että veroviranomaiset eivät tunne taiteilijoiden työskentelytapoja.

Kuvataiteilijat tarvitsevat erillisen työhuoneen jo siitä syystä, että työrauha on luovan taiteellisen toiminnan välttämätön edellytys. Työrauhaa ratkaisevampana syynä työhuoneen tarpeellisuuteen on kuitenkin se tosiasia, että kuvataiteilijan käyttämät telineet, työpöydät, grafiikkapainot ym. työvälineet, materiaalit ja mallit sekä keskeneräiset ja valmiit taideteokset vaativat tilaa. Eikä tarvitse omata paljon mielikuvitusta ymmärtääkseen, että kuvanveistäjän ei sovi hakata marmoria tai hitsata kuparipeltiä perheensä olohuoneessa. Kuvataiteilijan toiminta vaatii työhuonetta aivan toisella tavalla kuin esim. peruskoulun tai lukion opettajan kotityöt tai muut sellaiset työt, joita varten työhuonevähennys vanhan käytännön mukaan hyväksytään verotuksessa.

Varsinkin jos taiteilijaa verotetaan ammatinharjoittajana EVL:n mukaan, mielestämme ei ole ylipäänsä sellaista perustetta, jonka mukaan nämä yhtenäistämisohjeet olisivat häneen sovellettavissa. Päinvastoin työhuonemenojen koko määrä on tällaisessa tapauksessa katsottava vähennyskelpoiseksi.

Riippumatta siitä, tapahtuuko verotus EVL:n vai TVL:n nojalla, on selvää, että erillisen, tähän tarkoitukseen nimenomaan hankitun työhuoneen vuokran tai yhtiövastikkeen, lämmitys-, sähkö-, siivous- ja korjauskustannusten ym. vastaavien kulujen on oltava kokonaan vähennyskelpoisia taiteilijan verotuksessa. 
Taiteelliseen toimintaan liittyvien menojen vähentämistä mm. eläketuloista koskee seuraava ennakkopäätös:

KHO 2009:106. Kun otettiin huomioon verovelvollisen taiteellinen peruskoulutus, usean ammattitaiteilijoille tarkoitetun järjestön jäsenyys sekä monivuotinen taiteellinen toiminta, johon oli kuulunut taiteellisten töiden tuottaminen ja taiteelliselta kannalta kansainvälisestikin menestyksekäs ja laaja näyttelytoiminta, se seikka, että verovelvollisen taiteellinen toiminta oli ollut tappiollista ja hänen ansiotulonsa oli kyseisenä verovuonna koostunut lähes yksinomaan työeläketulosta, ei ollut este verovelvollisen taiteen harjoittamisen pitämiselle TVL 31.1 \$:n 4 kohdassa tarkoitettuna taiteellisena toimintana, josta aiheutuneet menot oli luonnollisina vähennyksinä vähennettävä verovelvollisen kyseisestä ansiotulosta.

Edellä luvussa 3.3.1 on tarkasteltu ammattitaiteilijan ja harrastelijan tärkeää eroa verotuksessa lähinnä tulolajivalinnan osalta. Kirjassa Andersson - Gyllström Kuvataiteilijan verotuksesta (1982 s. 19-20) todetaan menojen vähentämisen osalta myös seuraavaa lähinnä menojen jaksotusta silmällä pitäen:

Jos taiteilijaa ei voida pitää ammattilaisena vaan hänet on katsottava harrastelijaksi, hänen tulojaan on tältä osin verotettava ns. muuna satunnaisena voittona. Tulon hankkimisesta aiheutuneiden menojen vähentäminen saattaa tulla kysymykseen vasta samana vuonna, jona tulotkin ovat veronalaisia, ja menot vähennetään mahdollisesti vain ao. veronalaisista voitoista. Jos siis harrastelijan menoja ei ole jonakin vuonna saatu vähentää, koska tuloja ei ole ollut, nämä menot on syytä pitää mielessä ja tuoda ne esiin jälleen myöhemmin, mikäli ne silloin ovat tuottaneet tuloa. Jos ammattitaiteilijalla on tällaisia vähentämättömiä menoja sen takia, että häntä on aikaisemmin verotuksessa pidetty harrastelijana, ko. menettely voi tulla kysymykseen silloin, kun hän esim. myynnin kautta saa tuloja aikaisemmin harrastelijana tekemästään teoksesta. Kun verotus tapahtuu EVL:n mukaan, veronalaiset tulot ja vähennyskelpoiset menot jaksotetaan asianomaisten verovuosien tuotoiksi ja kuluiksi.

Seuraavaksi siirrytäänkin tarkastelemaan tulojen ja menojen ajallista kohdistamista eli jaksottamista. 


\subsection{Ajallinen kohdistaminen}

\subsubsection{Tulojen ja menojen jaksotuksesta yleensä}

TVL 110 \$:ssä on tulon jaksottamista koskeva yleissäännös. Sen mukaan tulo katsotaan sen verovuoden tuloksi, jona se on nostettu, merkitty verovelvollisen tilille tai muutoin saatu vallintaan. Luovutusvoitto katsotaan kuitenkin sen verovuoden tuloksi, jona kauppa tai vaihto on tehty tai muu luovutus on tapahtunut.

Menon jaksottamista koskeva yleissäännös on TVL 113 \$:ssä. Sen mukaan verovelvollisen suorittamaan menoon perustuva, tulosta tehtävä vähennys tehdään, jollei erityisestä syystä muuta johdu, sinä verovuonna, jona maksu on suoritettu. Verovelvollisen tulonhankinnassa käytettyjen koneiden ja kaluston yms. hyödykkeiden hankintamenot vähennetään kuitenkin vuotuisina poistoina noudattaen soveltuvin osin EVL:n säännöksiä (ks. tarkemmin TVL $114 \$$ ).

Tulo, joka on saatu toiminnasta, josta verovelvollinen on kirjanpitovelvollinen, ja meno, joka liittyy tällaiseen toimintaan, jaksotetaan EVL:n mukaan (TVL 116 \$). EVL:n jaksotussäännökset (19-49 \$) perustuvat suoriteperiaatteeseen. Vaihto-omaisuuden jaksotuksesta säädetään EVL 28 \$:ssä. Vaihto-omaisuutta ovat EVL 10 \$:n mukaan elinkeinotoiminnassa luovutettavaksi tarkoitetut kauppatavarat ja muut hyödykkeet sekä elinkeinotoiminnassa kulutettavaksi tarkoitetut tarvikkeet.

Käyttöomaisuuden jaksotuksesta säädetään EVL 30-49 §:ssä. Käyttöomaisuutta ovat EVL 12 \$:n mukaan elinkeinossa pysyvään käyttöön tarkoitetut esineet sekä patentit ja muut erikseen luovutettavissa olevat aineettomat oikeudet ja eräät muutkin hyödykkeet.

Kirjassa Andersson - Gyllström Kuvataiteilijan verotuksesta (1982) s. 12 kuvataan kuvataiteilijan jaksotuskysymystä seuraavasti:

Kuvataiteilijan tulot yleensä ja varsinkin myyntitulot ovat tavallisesti erittäin epätasaisia vaihdellen hyvin paljon vuodesta toiseen. Onnistunut näyttely tai suurempi tilaustyö merkitsee tavallista enemmän tuloja, mutta sitten voi taas seurata pari vaikkapa tappiollista vuotta ennen seuraavaa näyttelyä tai tilaustyötä.

Näyttelykin on hyvin usein taiteilijalle tappiollinen. Sen taloudellinen menestys riippuu nimittäin monesta tekijästä, johon taiteilija ei itse voi 
vaikuttaa. Voimme esimerkkinä mainita taidearvostelun, jolla on suuri vaikutus yleisön ostohaluun ja joka sattumanvaraisesti voi olla myönteinen tai kielteinen riippuen siitä, ketkä taidearvostelijat ovat saaneet tehtäväkseen kirjoittaa ko. näyttelystä eri lehtiin.

Suuren tilaustyön tekeminen saattaa joskus tulla taiteilijan osaksi kilpailun jälkeen. Tällöin ja muutenkin saattaa kestää useitakin vuosia työn aloittamisesta, ennen kuin maksu suoritetaan. Toisaalta ei ole lainkaan harvinaista, että ainakin osa tilatun teoksen hinnasta maksetaan etukäteen.

TVL:n mukaan verotettavan taiteilijan ei tarvitse eikä hänen pidäkään aktivoida esim. vaihto-omaisuusmenojaan, vaan hän saa vähentää menonsa sitä mukaa kuin ne syntyvät. Sen sijaan EVL:n mukaan verotettavan taiteilijan pitää ainakin periaatteessa aktivoida vaihto-omaisuusmenonsa ja vähentää ne sitä mukaa kuin ko. vaihto-omaisuus luovutetaan tai tulee kulutetuksi tai epäkurantiksi.

Tuloverolain mukaan verotettavan sellotaiteilijan verotukseen liittyy seuraava merkittävä melko tuore ennakkopäätös:

KHO 2019:124. A toimi korkeakoulun musiikin professorina ja esiintyvänä sellotaiteilijana. Hän oli vuonna 2013 myynyt vuonna 1989 hankkimansa C-merkkisen sellon 360000 eurolla ja hankkinut yhteensä 227000 euroa maksaneet D-merkkisen sellon ja jousen. A oli käyttänyt vuonna 2013 hankkimiaan selloa ja jousta työssään. A oli verovuodelta 2013 antamassaan veroilmoituksessa ilmoittanut verotettavien ansiotulojensa vähennyksenä sellon ja eri vuosina hankkimiensa jousien hankintamenoista tehtyinä poistoina yhteensä 60 638,22 euroa. A:n verotusta toimitettaessa poistot oli hyväksytty A:n verotettavien ansiotulojen vähennyksiksi. Veronsaajien oikeudenvalvontayksikkö oli vaatinut, että sellon ja jousien hankintamenoista tehdyt poistot oli luettava A:n verotettaviin tuloihin, koska selloa ja jousia tuli pitää arvosoittimina, jotka taide- ja näyttelyesineiden tavoin olivat kulumattoman käyttöomaisuuden kaltaista omaisuutta ja joiden hankintamenoja ei siten voitu vähentää vuotuisina poistoina. KHO totesi, että sello ja jouset olivat olleet niiden varsinaisen käyttötarkoituksen mukaisessa käytössä. Asiassa ei ollut väitetty, että $\mathrm{A}$ olisi keräillyt soittimia tai että hän olisi aktiivisesti ostanut ja myynyt soittimia. A:n vuonna 2013 hankkimaa selloa ja eri vuosina hankkimia jousia ei siten voitu rinnastaa taide- tai näyttelyesineisiin eikä vaihto-omaisuuteen, vaan sello ja jouset oli katsottava koneiden ja kaluston kaltaisiksi hyödykkeiksi, joiden hankintamenoista voitiin tehdä tuloverotuksessa vähennyskelpoisia poistoja. TVL 29.1 \$, 31.1 \$:n 4 kohta, $114.1 \$$; EVL $12 \S, 30.1 \S$ ja $42.2 \$$. 


\subsubsection{Aineettoman hyödykkeen hankintameno ja sen vähentäminen}

EVL 37 \$:n mukaan patentin ja muun voimassaoloajaltaan rajoitetun erikseen luovutettavissa olevan aineettoman oikeuden sekä sellaisen erikseen luovutettavissa olevan aineettoman oikeuden, jonka voimassaoloaikaa ei ole rajoitettu, hankintameno poistetaan yhtä suurin vuotuisin poistoin 10 vuodessa tai verovelvollisen todennäköiseksi osoittamana sitä lyhyempänä oikeuden taloudellisena käyttöaikana. Jos EVL 37 §:ssä tarkoitettu aineeton oikeus luovutetaan tai menetetään, verotuksessa jäljellä oleva poistamaton hankintamenon osa vähennetään EVL 41 \$:n mukaisesti sinä verovuonna, jona omaisuus on luovutettu tai menetys todettu (KHO 2008 T 3372).

Esimerkiksi tekijänoikeuden, kustannusoikeuden ja tavaramerkkioikeuden hankintameno on aktivoitava ja poistettava viimeistään kymmenessä vuodessa. Jos oikeus on hankittu käypää vastiketta vastaan, asia vaikuttaa varsin selvältä. Jos yritys on esimerkiksi ostanut tässä tarkoitetun oikeuden, se vähentää vuotuisista tuloistaan hankintamenon tasapoistoin.

Itse kehitettyjen hyödykkeiden hankintameno määritellään poistopohjaa varten hankinnasta johtuneiden todellisten muuttuvien menojen perusteella edellyttäen, ettei näitä menoja ole jo aikaisemmin vähennetty esimerkiksi kehittämismenoina.

Tilanne on ongelmallisempi vastikkeetta saatujen aineettomien oikeuksien osalta. Vastikkeetta saatuina voidaan pitää perintönä, lahjana tai muulla näihin verrattavalla tavalla saatuja oikeuksia, mutta ei yrityksen itsensä kehittämiä aineettomia oikeuksia.

EVL 15 \$:n mukaan perintönä, lahjana tai muulla niihin verrattavalla saannolla vastikkeetta saadun rahoitus-, vaihto-, sijoitus- ja käyttöomaisuuden vähennyskelpoiseksi hankintamenoksi katsotaan hyödykkeen todennäköinen luovutushinta saannon hetkellä tai sitä alempi todennäköinen luovutushinta sinä ajankohtana, jona hyödyke otetaan elinkeinotoiminnan käyttöön. Jos verovelvollinen on saanut koko liikkeen tai ammatin vastikkeetta, vähennetään saadun rahoitus-, vaihto-, sijoitus- ja käyttöomaisuuden hankintameno kuitenkin samalla tavalla kuin se olisi vähennetty saantomiehen tuloista. 
Jos esimerkiksi tekijänoikeudet ovat siirtyneet koko elinkeinon vastikkeettoman luovutuksen yhteydessä, asia on varsin selvä: saaja jatkaa samoista arvoista, jotka olivat luovuttajalla. Poistopohjaa ei siis muuteta. Jos luovuttajan tuloverotuksessa ei ole enää jäljellä hankintamenoa, sellaista ei synny uudellekaan omistajalle.

Jos oikeus luovutetaan erikseen, hankintamenoon ei sovelleta jatkuvuusperiaatetta, vaan uuden omistajan verotuksessa oikeuden hankintamenoksi määritellään oikeuden todennäköinen luovutushinta eli käypä arvo saantohetkellä tai sitä alempi arvo ajankohtana, jona hyödyke otetaan elinkeinotoiminnan käyttöön. Tällaisella hinnalla tarkoitetaan yleensä lahja- tai perintöverotuksessa vahvistettua arvoa. Kuolinpesän verotuksessa ei oikeuskäytännön mukaan kuitenkaan käytetä todennäköistä hankintamenoa kuolinhetkellä (KHO 1979 II 553 ja KHO 21.1.1997 T 65).

Esimerkiksi tavaramerkkioikeus on oikeuskäytännössä luettu varoihin, joista maksetaan perintö- ja lahjaveroa, joten sille pitäisi löytyä arvo. Tilanne on ongelmallisempi tekijänoikeuksien osalta, koska tekijänoikeuksia ei ole oikeuskäytännössä pidetty perintö- ja lahjaverotuksessa veronalaisina varoina. Sikäli kuin tekijänoikeudelle on perukirjassa merkitty luotettava arvo, poistopohjana tuloverotuksessa voitaneen käyttää sitä. Silloin kun kysymyksessä on hyödyke, jonka vastikkeellisesta luovutuksesta ei makseta perintö- tai lahjaveroa, verovelvollisen intressissä on käyttää mahdollisimman suurta arvoa ja näin saada suuri poistopohja, kun taas veronsaajien edun mukaista on käyttää mahdollisimman pientä arvoa.

Jos TVL:n mukaan verotettava verovelvollinen myy vastikkeellisesti tai vastikkeetta saamansa tekijänoikeuden, joudutaan ratkaisemaan, sovelletaanko myyntiin luovutusvoittoja ja luovutustappioita koskevia säännöksiä vai aineettomiin oikeuksiin perustuvia korvauksia koskevaa TVL 52 §:ää, jonka mukaan korvaus lahjana saadusta tekijänoikeudesta on ansiotuloa. Perintönä tai ostamalla saadusta tekijänoikeudesta saatu tulo taas on pääomatuloa. Jos tapaukseen sovelletaan luovutusvoittoa koskevia TVL:n sän̈nöksiä, tulo verotetaan aina pääomatulona, ja luonnollisen henkilön ja kuolinpesän kohdalla sovellettavaksi voi tulla myös hankintameno-olettama (20 tai $40 \%$ luovutushinnasta). 
Jos kirjailija siirtää tekijänoikeutensa yhtiölleen, voidaan kysyä, tapahtuuko hänen verotuksessaan yksityisotto ja yhtiössä pääomansijoitus ja miten aineettoman omaisuuden yksityisotto käsitellään yksityisen elinkeinonharjoittajan verotuksessa, sekä voisiko kysymyksessä olla yritysmuodon muutos ja miten sellaista kohdeltaisiin.

\subsubsection{Tappiontasaus}

\subsubsection{Tappiontasausjärjestelmä}

Eri verovuosien välinen avoin tappiontasausjärjestelmä tuli Suomeen vasta 1960-luvun lopussa. Se on nykyisin niin luonnollinen ja olennainen osa tuloverojärjestelmää, että voidaan suorastaan ihmetellä, miten ilman sitä oli tultu toimeen. Keskeinen keino vuosittaisten tulosten tasaamiseksi ja siten myös tappioiden välttämiseksi perustui aikoinaan vaihto-omaisuuden joustaviin jaksotussäännöksiin, joita ei enää ole.

Vahvistetut tappiot vähennetään meillä sovellettavassa järjestelmässä sitä seuraavien vuosien tuloista siinä järjestyksessä, jossa ne ovat syntyneet (TVL 117 \$). Niitä ei voida vähentää aikaisempien vuosien tuloista.

\subsubsection{Luonnolliset henkilöt}

Luonnollisen henkilön ja kuolinpesän tulo jaetaan kahteen tulolajiin: pääomatuloon ja ansiotuloon (TVL 29.2 \$).

Ansiotulolajin tappiolla tarkoitetaan sitä määrää, jolla verovelvollisen ansiotulojen hankkimisesta tai säilyttämisestä johtuneiden vähennysten yhteismäärä verovuonna ylittää hänen veronalaisten ansiotulojensa määrän (TVL 118.2\$). Ansiotulolajin tappio vähennetään valtionverotuksessa seuraavan 10 verovuoden aikana verovuoden ansiotulosta ja kunnallisverotuksessa verovuoden tulosta sitä mukaa kuin näitä tuloja syntyy (TVL 118.1\$).

Ansiotulojen kohdalla harvemmin syntyy verotuksessa vahvistettavaa ja vähennettävää tappiota, mutta sekin on mahdollista. Esimerkiksi kirjailijalla tai taiteilijalla voi olla verovuonna etupäässä kuluja työstä, joka myöhempinä vuosina tuottaa ansiotuloja. Tappio ansiotulolajissa voi tulla ajankohtaiseksi myös esimerkiksi palkansaajan 
joutuessa maksamaan suuren korvauksen työssään aiheuttamastaan vahingosta. Ansiotulolajin tappiota ei voi koskaan vähentää pääomatuloista.

Luonnollisen henkilön elinkeinotoiminnan verovuoden tappio vähennetään lähtökohtaisesti elinkeinotoiminnan tuloksesta seuraavan 10 verovuoden aikana sitä mukaa kuin tuloa syntyy (TVL $119.1 \$$ ). Elinkeinotoiminnan tappiolla tarkoitetaan elinkeinoverolain mukaan laskettua tappiollista tulosta (TVL 119.2 \$). Verovelvollisen ennen verovuodelta toimitettavan verotuksen päättymistä esittämästä vaatimuksesta elinkeinotoiminnan tappio voidaan kokonaan tai osittain vähentää luonnollisen henkilön tappiovuoden pääomatuloista (TVL 59 \$).

Jos luonnollisen henkilön tai kuolinpesän vähennyskelpoisten tulonhankkimismenojen ja pääomatuloista vähennettävien tappioiden yhteismäärä on suurempi kuin veronalaisten pääomatulojen yhteismäärä, erotus on pääomatulolajin alijäämä, jonka perusteella verovelvollisella on oikeus tehdä verosta pääomaveroprosentin mukainen alijäämähyvitys (TVL $60 \$$ ).

Siltä osin kuin pääomatulolajin alijäämää ei ole otettu huomioon verovuoden verosta tehtävänä vähennyksenä, se vahvistetaan pääomatulolajin tappioksi (TVL 60.2\$), joka vähennetään verovelvollisen seuraavien 10 vuoden pääomatuloista sitä mukaa kuin pääomatuloa syntyy (TVL $118 \$$ ).

Jos elinkeinotoiminnan tappiota ei voida toiminnan lopettamisen vuoksi voida vähentää elinkeinotoiminnasta, vähennetään vähentämättä jääneet tappiot verovelvollisen pääomatuloista tappiovuotta seuraavien 10 verovuoden aikana (ks. TVL $121 \$)$.

\subsubsection{Yhtiöt}

Osakeyhtiöiden, avoimien yhtiöiden ja kommandiittiyhtiöiden verovuoden tappio vähennetään yhtiön tulosta 10 seuraavan verovuoden aikana sitä mukaa kuin tuloa syntyy (TVL 119-120 \$). Elinkeinotoiminnan tappiolla tarkoitetaan EVL:n mukaan laskettua tappiollista tulosta. Osakeyhtiön elinkeinotoiminnan tappion määrää laskettaessa otetaan lisäksi huomioon TVL 57 \$:ssä tarkoitettu lahjoitusvähennys. Yhtiöiden tappiot eivät ole vähennyskelpoisia osakkaiden verotuksessa. Yhtiöiden oikeus tappionvähennykseen saatetaan menettää laissa hyväksyttyä suurempien omistajanvaihdosten vuoksi (TVL $122 \$$ ). 


\subsubsection{Tulontasaus}

Valtionverotuksessa ansiotuloihin sovellettavan veroasteikon progression vuoksi joutuu sellainen henkilö, jonka tulot vuosittain vaihtelevat huomattavasti, huonompaan asemaan kuin sellainen, jonka useamman vuoden ajanjakson tulot ovat kylläkin yhtä suuret mutta kertyvät vuodesta toiseen tasamääräisinä. Suurempaa veronmaksukykyä ei hänellä kuitenkaan sinänsä ole.

Progressiivisesta asteikosta aiheutuva vaihtelevien tulojen lisärasitus on erityisen tuntuva silloin, kun verovelvollinen yhdellä kertaa saa säännönmukaisiin tuloihinsa verrattuna huomattavan suuren tuloerän, joka on korvausta usean vuoden työstä tai on muutoin kertynyt usealta vuodelta. Tämä voi koskea erityisesti kirjailijoita, taiteilijoita ja keksijöitä, jotka usein työskentelevät vuosia suuren työn parissa ennen kuin tulo realisoituu.

Tähän epäkohtaan ei verotuksessamme ennen vuotta 1969 kiinnitetty mitään huomiota. Sovellettaessa kassaperiaatetta sanotunlaiset kertatulot katsottiin aina sen verovuoden tuotoksi, jonka aikana ne oli nostettu tai jona ne olivat olleet verovelvollisen nostettavissa. Ulkomailla sitä vastoin oli yleisesti pyritty erityissäännöksillä vähentämään suurista, usean vuoden työhön perustuvista kertatuloista verotuksessa aiheutuvaa lisärasitusta. Niin tehdään nykyisin myös meillä. Tulontasausta säännellään TVL 128 ja 129 \$:issä:

\section{$128 \$$ Tulontasauksen edellytykset}

Jos luonnollinen henkilö tai kuolinpesä on verovuonna saanut vähintään 2500 euron suuruisen ansiotulon, joka on kertynyt etu- tai jälkikäteen kahdelta tai useammalta vuodelta ja joka on vähintään neljäsosa hänen verovuonna saamansa puhtaan ansiotulon yhteismäärästä, on tällaista kertatuloa verotettaessa verovelvollisen ennen verotuksen päättymistä esittämästä vaatimuksesta toimitettava tulontasaus.

Kahdelta tai useammalta vuodelta kertyneenä ansiotulona voidaan pitää muun muassa:

1) aikaisemmilta vuosilta saatua palkkaa tai verovuodelta ja sitä edeltäneeltä vuodelta saatua eläkettä;

2) verovelvollisen työstä erotessaan saamaa kertakorvausta;

3) liikettä luovutettaessa saatua tuloa;

4) tuloja tekijänoikeudesta tai patentista, ellei kyseessä ole 52 §:ssä tarkoitettu pääomatulo. 
Kahdelta tai useammalta vuodelta kertyneenä ansiotulona voidaan pitää myös taiteilijan valmistaman yhden tai useamman taideteoksen kalenterivuoden aikana tapahtuneesta yhdestä tai useammasta myynnistä saamien tulojen yhteismäärää.

Jos edellä 1 momentissa tarkoitettu kertatulo sisältyy elinkeinotoiminnan tai maatalouden tulokseen, katsotaan tulontasauksen kohteena olevaksi kertatuloksi yhtä suuri suhteellinen osuus kertatulon kokonaismäärästä kuin ansiotulon osuus on verovelvollisen elinkeinotoiminnan tai maatalouden tuloksesta.

\section{S Tulontasauksen toimittaminen}

Tulontasausta varten jaetaan 128 \$:ssä tarkoitettu tulontasauksen kohteena oleva kertatulo niiden vuosien lukumäärällä, joilta tulon katsotaan kertyneen, kuitenkin enintään viidellä.

Kertatulon osasta menevä vero lasketaan siten, että yksi kertatulon osista lisätään verovelvollisen verovuoden muuhun verotettavaan ansiotuloon ja näiden tulojen yhteismäärästä lasketusta verosta vähennetään verovuoden muusta verotettavasta ansiotulosta menevä vero. Kertatulosta menevä vero saadaan kertomalla kertatulon osasta menevä vero niiden vuosien lukumäärällä, joilta tulon katsotaan kertyneen. Kertatulosta menevä vero, joka on tulontasauksen yhteydessä kuitenkin vähintään 15 prosenttia kertatulosta, pannaan maksettavaksi verovuoden verona.

Tulontasaussäännöstöä sovelletaan ansiotulojen verotukseen valtionverotuksessa. Tulontasaus ei koske pääomatuloa, joka on vain lievästi progressiivinen. Tulontasausta ei sovelleta kunnallisverotukseen, vaikka siinäkin on alhaisella tulotasolla tiettyjen vähennysten takia progressiivisia piirteitä.

Tulontasaus koskee vain luonnollisia henkilöitä ja kuolinpesiä. Tulontasaukseen oikeuttaa vain tulo, joka on saatu vuotta pitemmältä ajalta; ei riitä, että tulo on saatu kahdelta kalenterivuodelta mutta yhteensä enintään 12 kuukaudelta (KHO 1975 T 3262). Ei myöskään riitä, että tulot ovat olleet tavallista suuremmat esimerkiksi ahkeramman työnteon, suuremman palkan tai tilapäisten ansioiden tms. seurauksena.

Laissa asetetaan vaatimuksia tulon suuruudenkin suhteen. Kertatulon täytyy olla vähintään 2500 euroa ja muodostaa vähintään neljäsosa verovelvollisen samana verovuonna saamien veronalaisten nettotulojen yhteismäärästä. Tulontasaus edellyttää verovelvolliselta aktiivisuutta eli tulontasausvaatimuksen esittämistä ennen verotuksen 
päättymistä. Tulontasaus ei ole verotettavan tulon vahvistamiseen vaan maksuunpanoon liittyvä toimi, se ei vaikuta tulon vahvistamiseen eikä vähennysten tekemiseen.

Kuvataiteilijoita koskee TVL $128.3 \$$. Sen mukaan kahdelta tai useammalta vuodelta kertyneenä ansiotulona voidaan pitää myös taiteilijan valmistaman yhden tai useamman taideteoksen kalenterivuoden aikana tapahtuneesta yhdestä tai useammasta myynnistä saamien tulojen yhteismäärää. Se, monelleko vuodelle tulontasaus toimitetaan, määräytynee sen mukaan, monenko vuoden aikana myydyt teokset on valmistettu. Tapauksessa KHO 1985 II 600 taiteilijan oli osoitettava lain asettamien vaatimusten täyttyminen taiteteosten osalta.

Tekijänoikeudesta saadut tulot voivat olla EVL:n mukaan verotettavaa elinkeinotuloa tai TVL:n mukaan verotettavaa ansiotuloa. Tulontasaussäännöstöä ei ole rajoitettu tapauksiin, joissa tulo on muuta kuin elinkeinotuloa. ${ }^{131}$ Tulontasausta voidaan siis soveltaa tekijänoikeustuloihin silloinkin, kun verovelvollinen on yksityinen elinkeinonharjoittaja. Asiaan ei tällöin vaikuta se, onko EVL:n mukaan verotettava taiteilija tai kirjailija soveltanut kassaperiaatetta EVL 27 a $\$: n$ sallimassa laajuudessa. Itsenäisenä yrittäjänä toimiva taiteilija on saanut tulontasauksen takautuvasta kertakorvauksesta, vaikka häntä on verotettu EVL:n nojalla (KHO 1983 T 4696). Ostetun tai perityn tekijänoikeuden luovutusvoitto on kuitenkin pääomatuloa (TVL 52 \$), eikä siihen sovelleta tulontasausta. Tekijänoikeuskorvauksia voi saada monena vuonna, kun esimerkiksi kirjaa myydään usean vuoden aikana. Siksi lähtökohtana on, että vain ensimmäiseen korvaukseen voidaan soveltaa tulontasausta (KHO 1987 B 570), ellei verovelvollinen vaadi, että vasta esimerkiksi toisen vuoden korvaukset ovat tulontasauksen alaisia.

Kertatulosta menevän valtionveron on tulontasausta sovellettaessa oltava aina vähintään $15 \%$, mikä merkitsee sitä, ettei tulontasauspyyntöä kannata esittää kokonaistulon ollessa alhainen. Myös valtion veroasteikon lievennykset ovat supistaneet tulontasauksesta saatavaa hyötyä.

131 Ks. myös Andersson - Gyllström Kuvataiteilijan verotuksesta (1982) s. 85. 


\subsubsection{Menovarausta ja taiteilijatiliä koskevat ehdotukset}

Vuoden 1985 taiteilijain verotustyöryhmä pohti muistiossaan lainsäädännön muuttamista niin, että ammatinharjoittajille säädettäisiin erityinen menovaraus, joka saisi olla enintään $30 \%$ verovelvollisen tilikauden voitosta ennen varauksen tekemistä ja joka olisi käytettävä ammatinharjoittamisesta johtuvien menojen kattamiseen kahden seuraavan verovuoden aikana.

Vuonna 1995 taiteilijain menovaraustyöryhmä laati esityksen menovaraukseksi. Sen mukaan enintään viideksi vuodeksi tehtävän menovarauksen vähimmäismäärä olisi ollut 10000 mk ja enimmäismäärä enintään 100000 mk; varauksen tuloutettavaa määrää olisi korotettu $12 \%:$ :lla kultakin vuodelta.

Taisto II -työryhmän muistiossa vuonna 2000 menovarauksen rinnalle esitettiin taiteilijan tekijäntiliä. Siinä suuret taiteellisen toiminnan kertatulot olisi talletetettu ulkopuolisen valvonnan alaiselle tilille, josta ne olisivat olleet nostettavissa viiden vuoden kuluessa taiteellisen toiminnan tulonhankkimismenojen katteeksi. Menettely olisi koskenut sekä TVL:n mukaan verotettavia että EVL:n mukaan verotettavia.

Vuonna 2002 eduskunta arvonlisäverolain muutosta käsitellessään hyväksyi lausuman (EV 170/2002), jossa se edellytti, että hallitus ryhtyy toimenpiteisiin, joilla selvitetään mahdollisuudet ottaa kuvataiteilijoiden verotuksessa käyttöön ns. taiteilijatili tai menovaraus, jolla voidaan lieventää niitä ongelmia, jotka johtuvat kuvataiteilijoiden työn erityisluonteesta.

Vuonna 2003 tehtiin lakialoite (32/2003), jonka allekirjoitti viidestä puolueesta (kok, vas, kesk, kd, vihr) yhteensä 32 kansanedustajaa. Lakialoitteessa ehdotettiin taiteilijoiden tuloksentasausmahdollisuuksia helpotettavaksi luomalla taiteenharjoittajille tekijätilimahdollisuus. Aloitteessa viitattiin TVL:n urheilijatulon jaksotussäännöksiin ja Ruotsin tekijätilijärjestelmään (upphovsmannakonto). EVL:iin olisi lisätty seuraavanlainen säännös: 


\section{9 b S Taiteilijatulon jaksottaminen}

Taiteilijan verovuoden tulona ei pidetä sitä osaa hänen ammattimaisesta taiteellisesta toiminnastaan tai tekijänoikeuslain (404/1961) nojalla saamastaan tulosta (taiteilijatulo), joka on talletettu valtiovarainministeriön hyväksymälle erityiselle tekijätilille. Tekijätilille siirrettävä määrä voi yhden verovuoden aikana olla vähintään 2000 euroa ja enintään 100000 euroa.

Tekijätilille talletettuja varoja voidaan nostaa taiteellisesta toiminnasta aiheutuvien tulonhankkimiskulujen kattamiseksi aikaisintaan neljän kuukauden kuluttua kyseisten varojen talletusajankohdasta.

Talletus on sen verovuoden tuloa, jona se on nostettu tekijätililtä, kuitenkin niin, että talletus on tuloutettava viimeistään talletusvuotta seuraavan viiden vuoden kuluessa.

Taiteilijalla voi samanaikaisesti olla käytössään ainoastaan yksi tekijätili. Tekijätiliä hyödyntävä taiteilija on kirjanpitolain $1 \$: n$ mukaan kirjanpitovelvollinen harjoittamastaan taiteellisesta toiminnasta. Taiteilijan on vuosittain toimitettava tekijätiliä koskevat, verotusta varten tarpeelliset tiedot verohallinnolle siten kuin verohallitus määrää.

Lisäksi kirjanpitolakia ehdotettiin muutettavaksi siten, että EVL 19 b §:ssä tarkoitettua tekijätiliä hyödyntävä taiteilija olisi ollut aina kirjanpitovelvollinen, mikä olisi TVL $116 \$$ huomioon ottaen ilmeisesti merkinnyt sitä, että myös TVL:n mukaan verotettava taiteilija olisi voinut hyödyntää tekijätilijärjestelmää.

Lakialoite raukesi vuonna 2007 ilman että sitä olisi käsitelty valiokunnissa. Myöhemmin Tarja Cronbergin laatimissa selvityksissä on menovaraus- ja tekijätiliasiaa pidetty vireillä (mm. opetus- ja kulttuuriministeriön työryhmämuistiossa 2011:19). ${ }^{132}$ Menovarausta on puollettu myös sillä, että sellainen on säädetty metsätalouden pääomatuloille (TVL $111 \$$ ).

Koska ehdotuksia tekijätilistä on puollettu mm. Ruotsin taiteilijatilijärjestelmällä ja Suomen urheilijatulojen rahastointimahdollisuudella, noita säännöstöjä on syytä esitellä tässä yksityiskohtaisemmin.

132 Myönteisesti asiaan on suhtautunut myös Rautiainen väitöskirjassaan (2013, s. 228). 


\subsubsection{Ruotsin taiteilijatili ja Suomen urheilutulojen rahastointi}

Tekijätilistä säädetään Ruotsin tuloverolain (inkomstskattelag 1999:1229) 32 luvussa. Ruotsin verohallinnon ohjeessa siitä todetaan mm.:

Vem fär göra avdrag för insättning på upphovsmannakonto?

En enskild näringsidkare som har en upphovsmannaintäkt i sin näringsverksamhet får göra avdrag för insättningar på upphovsmannakonto. Som upphovsmannaintäkt räknas intäkter i egenskap av upphovsman enligt lagen (1960:729) om upphovsrätt till litterära eller konstnärliga verk. Endast en fysisk person som obegränsat skattskyldig vid utgången av beskattningsåret kan få avdrag. Ett dödsbo får inte göra avdrag. Av detta följer att avdrag inte får göras dödsåret.

\section{Övriga förutsättningar för avdrag}

De sammanlagda upphovsmannaintäkterna under beskattningsåret måste överstiga motsvarande intäkter under något av de två närmast föregående beskattningsåren med minst $50 \%$. Näringsidkaren får inte göra avdrag från en intäkt som avser fotografiska verk. Uttag från ett upphovsmannakonto ses inte som en upphovsmannaintäkt.

Näringsidkaren får bara göra insättningar på ett upphovsmannakonto $i$ ett och samma kreditinstitut för ett visst beskattningsår. Om näringsidkaren gör insättningar i flera kreditinstitut får denne bara göra avdrag för insättningar hos det först anlitade kreditinstitutet. För att fă göra avdrag för insättning på ett upphovsmannakonto måste näringsidkaren göra insättningen på ett upphovsmannakonto senast den dag som denne ska lämna inkomstdeklaration enligt skatteförfarandelagen (2011:1244). Om näringsidkaren får anstånd med att lämna sin självdeklaration förskjuts senaste inbetalningsdag i motsvarande mån. För att godtas som upphovsmannakonto måste kontot vara ett konto hos ett svenskt kreditinstitut eller ett utländskt kreditinstitut i Sverige. Som ytterligare krav gäller att ränta måste tillgodoräknas minst en gång per år.

Vem är upphovsman?

Upphovsman är den som skapat ett litterärt eller konstnärligt verk. Sådana verk kan enligt 1 kap. $1 \$$ lagen (1960:729) om upphovsrätt till litterära och konstnärliga verk vara

- skönlitterära eller beskrivande framställningar i skrift eller tal

- musik eller sceniska verk 
- filmverk eller alster av bildkonst

- alster av byggnadskonst eller brukskonst

- verk som kommit till uttryck på annat sätt.

Något krav på konstnärligt värde ställs inte. Däremot måste verken ha en viss individuell prägel. Vad som brukar kallas hötorgskonst är alltså konstnärliga verk i detta sammanhang. Prestationer av mer alldaglig och rutinmässig karaktär omfattas däremot inte. Hit räknas t.ex. meddelanden, notiser, faktasammanställningar och enklare nyttoföremål samt journalfilmer som endast registrerar ett händelseförlopp.

\section{Hur stort avdrag fär man göra?}

Näringsidkaren får göra avdrag med högst ett belopp som motsvarar upphovsmannaintäkten. Avdraget får inte heller överstiga ett belopp som motsvarar två tredjedelar av överskottet av näringsverksamheten före avdrag för insättning på upphovsmannakonto och avdrag för avsättning för egenavgifter enligt 16 kap. $29 \$$ IL. Man får inte göra avdrag med så stort belopp att överskottet efter avdraget, men före avsättning för egenavgifter, understiger $30000 \mathrm{kr}$. Avdraget ska avrundas nedåt till helt tusental kronor och făr inte understiga $10000 \mathrm{kr}$.

\section{Räntan på kontot källbeskattas}

Ränta på upphovsmannakonto beskattas med källskatt $15 \%$. Varje gång ränta gottskrivs upphovsmannakontot ska kreditinstitutet hålla inne skatt för kontoinnehavarens räkning. Resterande del av räntan beskattas i inkomstslaget näringsverksamhet när beloppet tas ut från kontot. Bestämmelser om skatt på räntan för upphovsmannakonton finns i lagen (1990:676) om skatt på ränta på skogskontomedel m.m.

När fär man ta ut medel frän kontot?

Näringsidkaren får göra uttag från ett upphovsmannakonto tidigast fyra månader efter insättningsdagen. Ett uttag făr inte vara mindre än $1000 \mathrm{kr}$ om inte hela det innestående beloppet tas ut. Kreditinstitutet ska betala ut eventuellt innestående medel som näringsidkaren inte tagit ut, inklusive ränta, sex år efter ingången av det år insättningen senast skulle ha gjorts enligt 32 kap. $6 \$$ IL.

\section{Ett uttag ska tas upp som intäkt av näringsverksambet}

Uttag från ett upphovsmannakonto ska tas upp som intäkt i inkomstslaget näringsverksamhet det beskattningsår då uttaget görs. Motsvarande gäller för kvarstående medel som ett kreditinstitut betalar ut eller skulle ha betalat ut efter sex år. 
Suomessa urheilutulojen jaksotussäännökset lisättiin TVL:iin lailla 5.3.1999/229. Säännökset perustuivat hallituksen esitykseen 278/1998, jossa urheilijoiden tulojen rahastointia ja sen verokohtelua selostettiin mm. seuraavasti:

Urheilijarahastoidea syntyi Kansainvälisen yleisurheiluliiton (IAAF) piirissä aikana, jolloin keskustelu urheilun kaupallistumisesta oli viriämässä. Alun perin rahastojen avulla oli tarkoitus ohjata urheilijoiden saamia tuloja heidän oman välittömän määräysvaltansa ulottumattomiin ja siten lieventää kuvaa urheilun ammattilaistumisesta ja kaupallistumisesta.

Meillä rahastoideaa on hyödynnetty lähinnä yksilölajeissa. Suomen Urheiluliitto ry:n yhteyteen perustettiin urheilurahasto vuonna 1984. Rahasto toimii liiton itsenäisenä omakatteisena rahastona. Se ylläpitää, valvoo ja hoitaa rahastoa IAAF:n sääntöjen edellyttämällä tavalla.

$[--]$

Verotuksessa yllä kuvattu rahastokäytäntö hyväksyttiin vuonna 1984. KHO otti päätöksessään 1984 T 1742 kantaa Suomen Urheiluliiton urheilurahastossa olevien varojen verotukseen.

[-- ]

Harkittaessa rahastointijärjestelmän kehittämistä on otettava kantaa kahteen eri tyyppiseen asiaan. Ensinnä on ratkaistava, miten yksilölajien urheilijoille voidaan turvata nykytyyppinen joustava varautuminen sellaisiin valmennuskuluihin, jotka seura korvaa joukkueurheilijoille, ja samalla poistaa järjestelmän epäterveet piirteet. Toiseksi on pohdittava, tarvitaanko kaikkia urheilijoita varten erityisiä verotuksellisesti edullisia urheilijarahastoja urheilu-uran jälkeistä sopeutumisvaihetta silmällä pitäen. Oikeus- ja verotuskäytäntö osoittaa, että nykytila kaipaa joka tapauksessa vähintään sääntöjen selkeyttämistä lain tasolla sekä valmennustilikäytännössä että urheilutulojen rahastoinnissa.

Painavimmat syyt, joiden perusteella urheilijatulon rahastointimahdollisuutta voidaan puoltaa, ovat urheilu-uran lyhyys ja urheilijan pakollisen sosiaaliturvan rajallisuus muihin ammatteihin verrattuna. Missään muussa ammatissa ei ole niin itsestään selvää kuin ammattiurheilussa, että aktiivinen, tuloa tuottava työvaihe kestää korkeintaan kymmenisen vuotta, harvoin niinkään pitkään. Urheilu-uran päätyttyä eläkettä ei makseta eikä sille olisi perusteitakaan, koska entinen urheilija on yleensä parhaassa työiässä. Useimmilla uraansa lopettelevilla urheilijoilla ongelmana on kuitenkin "siviiliammatin" puute, sillä opiskelu urheilu-uran aikana on entistä vaikeampaa urheilun ammattimaistumisen vaatiman työmäärän takia.

Rahastoinnin avulla voitaisiin yhteiskunnankin kannalta edullisella tavalla edistää entisten urheilijoiden sopeutumista normaaliin työelämään tai opiskeluun. Onhan rahastoinnissa kysymys urheilijan omien varojen säästämisestä. Yhteiskunnan tuki verotulojen lykkääntymisen muodossa 
jäisi sittenkin julkistalouden kannalta melko vähäiseksi. Avoin, säännöiltään selkeä ja lain tasolla riittävästi säännelty rahastointijärjestelmä olisi myös omiaan tuomaan päivänvaloon sellaisia urheilutuloja, joiden saaminen verottajan ulottuville on nykyisessä tilanteessa epävarmaa. Rahastointia puoltavat myönteiset kansainväliset kokemukset.

\section{Urheilutulojen jaksotusta koskevat säännökset kuuluvat nykyisin lukuisten muutosten jälkeen seuraavasti:}

\section{6 a S Urheilutulon jaksottaminen}

Urheilijan verovuoden tulona ei pidetä sitä osaa hänen välittömästi urheilemisesta saamistaan tuloista (urheilutulo), joka on 116 b ja 116 c \$:ssä säädetyin edellytyksin maksettu valtiovarainministeriön nimeämän säätiön yhteydessä olevaan valtakunnalliseen valmennusrahastoon tai urheilijarahastoon, joiden on kustakin urheilijasta vuosittain toimitettava verotusta varten tarpeelliset tiedot Verohallinnolle. Verohallinto määrää tarkemmin annettavista tiedoista.

Urheilutuloina pidetään urheilukilpailusta saatuja rahapalkintoja ja muita kilpailemisesta tai pelaamisesta saatuja ja niihin rinnastettavia tuloja sekä urheilemiseen liittyvistä mainossopimuksista tai muista yhteistyösopimuksista saatuja tuloja, jos sopijapuolina ovat urheilija, lajiliitto ja yhteistyötaho yhdessä. Urheilutulona ei pidetä edellä 82 \$:n 1 momentin 4 kohdassa tarkoitettua valmennus- ja harjoitteluapurahaa eikä lajiliitolta tai olympiakomitealta saatua tai näihin rinnastettavaa valmennustukea.

\section{6 b S Valmennusrahasto}

Valmennusrahastoon voidaan maksaa muita urheilutuloja kuin palkkaa. Valmennusrahastoon maksettua urheilutuloa voidaan käyttää urheilemisesta ja valmentautumisesta verovuoden aikana aiheutuvien tositteisiin perustuvien menojen kattamiseen. Rahastossa verovuoden päättyessä oleva määrä katsotaan verovuoden veronalaiseksi ansiotuloksi siltä osin kuin sitä ei ole siirretty urheilijarahastoon. Valmennusrahastoon voidaan kuitenkin vuosittain jättää verovapaasti tulevaa valmentautumista varten enintään 20000 euroa (valmennuskate).

Jos valmennusrahastoon on maksettu kahtena peräkkäisenä vuotena urheilutuloa vähemmän kuin 800 euroa vuodessa, rahastossa jäljellä olevat varat katsotaan kokonaisuudessaan näitä vuosia seuraavan verovuoden veronalaiseksi ansiotuloksi ellei urheilija ole jo aikaisemmin ilmoittanut urheilu-uran päättymisestä valmennusrahastolle.

\section{6 c $\$$ Urheilijarahasto}

Urheilijalla, jonka verovuoden urheilutulo on ennen tulon hankkimisesta tai säilyttämisestä aiheutuneiden menojen vähentämistä vähintään 9600 
euroa, on oikeus siirtää urheilutulostaan verovapaasti urheilurahastoon enintään 50 prosenttia urheilutulon bruttomäärästä laskettuna ja samalla enintään 200000 euroa vuodessa.

Urheilijarahastoon siirretyt varat tuloutuvat urheilijauran päättymistä seuraavien vähintään kahden ja enintään 15 vuoden aikana siten, että kunakin verovuonna tuloutuu tuloutumisvuosien lukumäärää vastaava osuus rahastossa urheilu-uran päättyessä olleesta määrästä. Erityisestä syystä, kuten työkyvyttömyyden tai vähintään vuoden kestäneen työttömyyden vuoksi, varat voidaan tulouttaa myös nopeammin ja tasaeristä poiketen. Rahastoon tuloutumisaikana kertynyt tuotto katsotaan viimeistä tuloutumisvuotta seuraavan verovuoden tuloksi.

Urheilu-ura katsotaan päättyneeksi, jos urheilutulo kahtena peräkkäisenä vuotena jää alle 9600 euron eikä urheilija osoita urheilijarahastolle jatkavansa urheilu-uraansa taikka jos vammautumisen tai urheilijan rahastolle tekemän ilmoituksen vuoksi urheilu-ura on päättynyt.

Jos urheilija kuolee, valmennusrahastossa ja urheilijarahastossa olevat varat katsotaan kokonaisuudessaan kuolinvuoden veronalaiseksi ansiotuloksi.

Urheilijarahastosta tuloutuvat varat ovat kokonaisuudessaan veronalaista ansiotuloa.

Hyvin mielenkiintoinen on e-urheilua koskeva KVL:n ratkaisu 2017:16, joka tavallaan lähentää urheilua taiteisiinkin. KVL totesi, että urheilulla laajasti käsitettynä voidaan fyysisten urheilulajien ohella tarkoittaa myös henkisiä taitolajeja, joissa menestyminen perustuu ensisijaisesti muuhun kuin fyysisenä pidettävään suoritukseen. Kun lisäksi otettiin huomioon urheilutulojen jaksottamista koskevan sääntelyn tarkoitus sekä hakijan kilpailumenestykseen perustuva tulonmuodostus, KVL katsoi, että hakijan tietokonepelin pelaamisesta saamat palkintotulot ja kuukausittainen palkkio olivat TVL 116 a.2 \$:n mukaista urheilutuloa, joka voidaan muiden laissa säädettyjen edellytysten täyttyessä siirtää urheilijarahastoon. ${ }^{133}$

Urheilua kutsutaan myös ruumiinkulttuuriksi, ja onpa olympialaisissa joskus ollut mukana myös taidelajejakin. ${ }^{134}$ Suomalaiset muistavat, että Berliinin olympialaisissa vuonna 1936 Urho Karhumäki

133 Juanto - Linnakangas Peliverot - vanhaa ja uutta, Verotus 2018 s. 606 ss.

134 Olympialaiset, engl. olympic games; games tarkoittaa kisoja. Ruotsissa käytetään ilmausta olympiska spelet; spel-sanalla on mm. seuraavat merkitykset: kisa, peli, soitto, musiikki-instrumentti, huuliharppu, haitari, näytelmä, urheilu, leikki. Suomessa pelimanni on vanhahtava nimitys soitinmusiikin esittäjästä. 
voitti kultamitalin rakkausromaanillaan "Avoveteen", josta tehtiin elokuvakin. Vuonna 1948 Lontoon olympiakisoissa suomalaiset menestyivät taidelajeissa vielä paremmin, vaikka useimmat ovat sen jo unohtaneet. Tuolloin suomaisten mitalisaalis oli seuraava: ${ }^{135}$

Kultaa: Aale Tynni runolla "Hellaan laakeri” ja Yrjö Lundegren urheilukeskuksen asemakaavalla.

Hopeaa: Kalervo Tuukkanen orkesterisävellyksellä "Karhunpyynti".

Pronssia: Ilmari Niemeläinen urheilukeskussuunnitelmalla.

\subsection{Veromäärä ja progressio}

1940-luvulla valtion progressiivisessa tuloveroasteikossa oli jopa 15 porrasta, joissa veroprosentti muuttui. Nykyisin portaita on enää neljä. Valtion tuloverotuksen korkeimmat marginaaliveroprosentit ylimmällä tulotasolla ovat vuosikymmenten alussa olleet seuraavat:

\begin{tabular}{|l|l|}
\hline vuosi & marginaalivero \\
\hline 1950 & $62 \%$ \\
\hline 1960 & $46 \%$ \\
\hline 1970 & $53 \%$ \\
\hline 1980 & $51 \%$ \\
\hline 1990 & $43 \%$ \\
\hline 2000 & $37,5 \%$ \\
\hline 2010 & $30 \%$ \\
\hline 2020 & $\begin{array}{l}31,25 \%(80500 ~ €: n \text { tulon ylittävältä osalta) + eläketulon lisävero } \\
5,85 \% .\end{array}$ \\
\hline
\end{tabular}

Kun otetaan huomioon valtionveron lisäksi maksettava kunnallisvero, marginaaliveroprosentti saattoi vielä 1980-luvulla ennen kokonaisverouudistusta nousta hyvin korkeaksi. Nykyisin kunnallisveronkin sisältävä korkein ansiotulojen marginaaliveroverosentti on noin 60 . Sote-uudistuksen yhteydessä vuodesta 2023 alkaen kunnallisvero

135 Ks. tarkemmin Nadja Mikkosen artikkeli Olympiamitalit Yle.fi/uutiset 15.8.2021. 
suunnilleen puolittuu mutta valtionvero vastaavasti nousee, joten valtionveron ja kunnallisveron yhteinen progressio pysyy suurin piirtein entisellään.

Vuoden 2023 valtion tuloveroasteikko on seuraavanlainen (laki 620/2021):

\begin{tabular}{|c|c|c|}
\hline $\begin{array}{c}\text { Verotettava ansiotulo, } \\
€\end{array}$ & $\begin{array}{c}\text { Vero alarajan kohdalla, } \\
€\end{array}$ & $\begin{array}{c}\text { Vero alarajan } \\
\text { ylittävästä tulon } \\
\text { osasta, } \%\end{array}$ \\
\hline $0-18100$ & 0 & 13,26 \\
\hline $18100-27200$ & 2400,06 & 19,00 \\
\hline $27200-44800$ & 4129,06 & 30,75 \\
\hline $44800-78500$ & 9541,06 & 34,50 \\
\hline $78500-$ & 21167,56 & 44,50 \\
\hline
\end{tabular}

\subsection{Henkilöllinen kohdistaminen ja taidetoiminnan yhtiöittäminen}

\subsubsection{Verosuunnittelu ja veronkiertäminen lähikäsitteineen ${ }^{136}$}

Verosuunnittelussa selvitetään erilaisten toimintavaihtoehtojen veroseuraamukset ja otetaan ne huomioon edullisuusvertailussa. Tyypillisiä verosuunnittelutilanteita ovat yritysmuodon valinta, tilinpäätössuunnittelu, sukupolvenvaihdokset sekä tavaroiden ja palvelujen hinnoittelu. Verosuunnittelun käsitteeseen ei välttämättä liity vaatimusta pienimpien verojen vaihtoehdon valinnasta; päätöksenteossa otetaan huomioon muitakin kuin verotusnäkökohtia. Verosuunnittelulla kuitenkin usein käytännössä tarkoitetaan verojen minimointia ainakin pitkällä aikavälillä.

Veron minimoinnilla puolestaan tarkoitetaan toimenpiteitä, joiden hallitsevana motiivina on veroedun saavuttaminen. Jos pyrkimyksessä onnistutaan, kysymyksessä on veron säästäminen.

136 Käsitteistä ks. mm. Tikka Veron minimoinnista (1972). 
Veron torjunta on yleistermi toimille, joilla pyritään vapautumaan veroista taloudellisena rasituksena. Verosta saatetaan vapautua laillisin keinoin, mutta veron torjunnalla tavoiteltu etu voidaan evätä verotuksessa..

Veronhuojennusten hyödyntäminen on laillinen veron torjunnan muoto. Veronhuojennukset ovat verotukia, joilla lainsäätäjä on tietoisesti luonut verovelvolliselle kannusteen toimia tietyllä tavalla. Laillista veron torjuntaa on sekin, että verovelvollinen jättää toteuttamatta tosiseikaston, josta veroa maksetaan (esim. palkansaaja vähentää työntekoa). Lailliseen veron torjuntaan kuuluu myös veronvyörytys, jossa vero siirretään hintaa korottamalla toisten rasitukseksi.

Laitonta veron torjuntaa on verovilppi, esimerkiksi väärä veroilmoitus. Verovilppiin liittyy myös rangaistus- ja veronkorotusseuraamuksia. Veropako puolestaan voi olla sekä laillista että laitonta. Laillista veropakoa voi olla esimerkiksi muutto lievemmän verorasituksen maahan, laittomia keinoja ovat $\mathrm{mm}$. yritysten peitellyt voitonsiirrot ulkomaille.

Veron kiertäminen kuuluu veron torjunnan laittomiin muotoihin. Sille on ominaista verolain säännöksen sanamuodon normaalin tulkinnan ja tarkoituksen välinen jännite. Usein kyse on tavanomaisesta vaihdantakäyttäytymisestä poikkeavista toimista, joilla pyritään saavuttamaan verolain tarkoitukselle vieraita veroetuja. Kysymys ei kuitenkaan ole verovilpistä; verovilpissä operointiin käytetään vääriä tietoja. Toimenpiteet voivat olla yksityisoikeudellisesti päteviä, vaikka ne verotuksessa sivuutetaan veronkiertämissäännöksen nojalla.

Verotusjärjestelmässä voidaan veronkiertämisongelmaan suhtautua erilaisilla tavoilla. Ensiksikin voidaan tyytyä normaalin tulkinnan mahdollisuuksiin, jolloin lain soveltaja ei useinkaan voi reagoida epäämällä veroedun. Tällöin lainsäädäntö monimutkaistuu, koska joudutaan laatimaan säännöksiä, joiden tehtävänä on estää kiertämästä muita verosäännöksiä.

Toiseksi lakia voidaan soveltaa sen tarkoituksen vastaisen veroedun epäämiseksi realistisemmallakin tavalla, joka ylittää normaalin tulkinnan mahdollisuudet. Suomessa on omaksuttu tämä suhtautumistapa säätämällä verolakeihin yleislauseke, joka antaa verotuksen toimittajalle normaalia lain soveltamista pidemmälle menevät mahdollisuudet ehkäistä veron kiertämistä. 
Tuloverotusta koskeva yleinen veronkiertämissäännös on verotusmenettelylain 28 \$:ssä:

Jos jollekin olosuhteelle tai toimenpiteelle on annettu sellainen oikeudellinen muoto, joka ei vastaa asian varsinaista luonnetta tai tarkoitusta, on verotusta toimitettaessa meneteltävä niin kuin asiassa olisi käytetty oikeaa muotoa. Jos kauppahinta, muu vastike tai suoritusaika on kauppa- tai muussa sopimuksessa määrätty taikka muuhun toimenpiteeseen on ryhdytty ilmeisesti siinä tarkoituksessa, että suoritettavasta verosta vapauduttaisiin, voidaan verotettava tulo ja omaisuus arvioida.

Jos on ilmeistä, että verotusta toimitettaessa olisi meneteltävä 1 momentissa tarkoitetulla tavalla, on verotusta toimitettaessa huolellisesti tutkittava kaikki ne seikat, jotka voivat vaikuttaa asian arvostelemiseen, sekä annettava verovelvolliselle tilaisuus esittää selvitys havaituista seikoista. Mikäli verovelvollinen ei tällöin esitä selvitystä siitä, että olosuhteelle tai toimenpiteelle annettu oikeudellinen muoto vastaa asian varsinaista luonnetta tai tarkoitusta taikka ettei toimenpiteeseen ole ryhdytty ilmeisesti siinä tarkoituksessa, että suoritettavasta verosta vapauduttaisiin, verotusta toimitettaessa on meneteltävä 1 momentissa tarkoitetulla tavalla.

Tuloverotuksen yleisen veronkiertämissäännöksen soveltamisen tyypillisiä tilanteita ovat seuraavat:

- Oikeudellisen muodon ja taloudellisen sisällön ristiriitatilanteet. Tällöin kysymys on yksityisoikeudellisten muotojen väärinkäytöstä.

- Perusteettomat sarjatoimet. Verovelvollinen jakaa kokonaisuuden peräkkäisissä oikeustoimissa keinotekoisesti useaan osaan saadakseen edullisemman verokohtelun kuin yhdellä oikeustoimella. Edestakaisilla oikeustoimilla pyritään kumoamaan tointen taloudelliset vaikutukset veroedun saavuttamiseksi.

- Intresssinpuute- ja intressiyhteystilanteet. Näissä tilanteissa vain toisella osapuolella on intressiä sitoutua tiettyihin sopimusehtoihin tai sopijapuolet ovat etuyhteydessä keskenään, jolloin on paineita mm. markkinaehtoisesta hinnoittelusta poikkeamiseen veronsaajan kustannuksella.

\subsubsection{Palkkiosta luopuminen ja palkkion luovuttaminen - puu ja hedelmät -oppi}

Henkilöllisessä kohdistamisessa on kyse siitä, kuka on oikea verovelvollinen - siis ketä tulee verottaa tietystä tulosta ja kenellä on oikeus vähentää tietty meno. Yleensä on selvää, ketä tietystä tulosta on verotettava: työtulosta verotetaan työn tekijää, elinkeinotulosta 
elinkeinonharjoittajaa ja pääomatuloista sen pääoman omistajaa, jonka omaisuuden tuotosta on kysymys. Tietyissä tilanteissa voi kuitenkin olla vaikea ratkaista, kuka on tulon tosiasiallinen saaja tai kenellä on oikeus tehdä tietty vähennys.

Tulo on sillä tavoin henkilökohtainen, että tulon saajalla ei ole oikeutta siirtää tuloaan verotettavaksi jollekulle muulle. Määräämällä tulosta hän ei voi välttää verotusta. Saadun tulon lahjoittaminen on tietenkin mahdollista, mutta tällöin tulosta on ensin verotettava lahjoittajaa. Tulon lähteen, esimerkiksi liikkeen, vuokratuloja antavan kiinteistön tai osinkotuloa antavien osakkeiden, lahjoittaminen on mahdollista, mutta tällöinkin lahjanantajaa on verotettava tuloista, jotka ovat kypsyneet ennen lahjan lopulliseksi tulemista.

Harvinaista ei ole, että tietyn omaisuuden omistaja lahjoittaa omaisuuden mutta pidättää itselleen omaisuuden tuoton. Tällöin häntä verotetaan tuosta tuotosta. Sitä vastoin verovelvollinen ei vero-oikeudellisesti voi menetellä niin, että hän pidättää itsellään omaisuutta mutta lahjoittaa sen tulevaa tuottoa.

Ilmiötä on kuvattu toteamalla, ettei verovelvollinen voi verotukseen vaikuttavalla tavalla luovuttaa puun hedelmiä luovuttamatta itse puuta ( uи ja hedelmät -oppi). ${ }^{137}$ Tästä seuraa toisaalta se, että tulon lähteen, kuten kiinteistön, liikkeen, patentin, osakkeiden tai muun sellaisen omaisuuden (vastikkeetonkin) luovutus siirtää luovutuksensaajalle tulon mutta myös velvollisuuden tulla siitä verotetuksi. Luovuttaja voi kuitenkin pidättää itselleen oikeuden omaisuuden tuottoon määräajaksi tai eliniäkseen ja tulee tällöin kyseisestä tuotosta myös verotetuksi. Aihepiiriin liittyy seuraava ns. Kristus-ratkaisu:

KHO 1983 II 602. Yhdistys A, jonka tarkoituksena oli auttaa Kristuksen lähetyskäskyn täyttämistä, oli tehnyt osakeyhtiö B:n kanssa sopimuksen, jonka mukaan yhdistys otti 4 kk:n ajaksi tehtäväkseen yhtiön yhden tai useamman työntekijän yötyövuoron tekemisen siten, että työn suorittivat yhdistyksen jäsenet yhtiön johdon ja valvonnan alaisena, mutta että korvaus työstä maksettiin kokonaan yhdistykselle. Se, että yhdistyksen jäsenet mainitulla tavalla luopuivat yhtiön heille tehtävän suorittamisesta

137 Puu ja hedelmät -opin sanotaan perustuvan USA:n korkeimman oikeuden tuomioon asiassa Lucas v. Earl (1930). Metaforan mukaan "the fruits cannot be attribted to a different tree from that on which they grew". Opissa korostetaan oikeustoimen sisältöä eikä muotoa. 
maksettavasta, EPL:n mukaiseksi palkaksi katsottavasta korvauksesta yhdistyksen hyväksi, ei vapauttanut yhtiötä velvollisuudesta toimittaa korvauksesta ennakonpidätys. Äänestys 3-1.

Kirjailijan tekijänoikeuksista on ollut kysymys seuraavassa keskusverolautakunnan julkaisemattomassa päätöksessä: ${ }^{138}$

KVL 1990:441. Kirjailija A aikoi lahjoittaa Suomen UNICEF-yhdistys ry:lle tekijänoikeutensa teoksiin $\mathrm{X}$ ja $\mathrm{Y}$. A ja B olivat aikaisemmin allekirjoittaneet teoksensa X kustannussopimuksen C Oy:n kanssa. Tämä kustannussopimus oli siirtynyt D Oy:lle. Teoksesta Y oli A aikaisemmin allekirjoittanut kustannussopimuksen E:n kanssa. Kustannussopimukset koskivat teosten ensimmäistä painosta ja seuraavia painoksia, joiden suuruuden kustantaja määräisi.

Lahjoituksiin liittyi seuraavia ehtoja. Ensinnäkin teosten sisältöä ja ulkoasua voitaisiin muuttaa ainoastaan A:n suostumuksella, ja A:lla olisi oikeus tarkistaa muutokset. Myös teosten ajantasaistamisen suorittaisi A, eikä sitä tullut antaa kenenkään toisen suoritettavaksi. Lisäksi A:lla oli oikeus käyttää korvauksetta katkelmia tekstistään, joka sisältyi teoksiin $\mathrm{X}$ ja Y.

Lahjoituksen yhteydessä siirtyisi oikeus tekijänpalkkioihin lahjansaajalle. A pyysi ennakkotietoa siitä, oliko hän verovelvollinen lahjakirjan allekirjoittamisen jälkeen lahjansaajille maksettavista tekijänoikeuspalkkioista vai siirtyikö verovelvollisuus lahjansaajalle.

KVL:n antamassa ennakkotiedossa viitattiin silloisen tulo- ja varallisuusverolain 43 \$:ään, jonka mukaan veronalaista tuloa olivat laissa jäljempänä mainituin rajoituksin verovelvollisen rahana tai rahanarvoisena etuutena saamat tulot. KVL totesi, että hakemuksessa tarkoitetussa tapauksessa ei lahjansaajalle siirtyisi muita merkittäviä oikeuksia kuin oikeus lahjakirjan allekirjoittamisen jälkeen maksettavien tekijänoikeuspalkkioiden saamiseen. KVL selitti ennakkotietona, että jos A lahjoitti hakemuksessa tarkoitetulla tavalla UNICEF-yhdistys ry:lle tekijänoikeudet teoksiinsa X ja Y, oli A verovelvollinen myös lahjakirjan allekirjoittamisen jälkeen UNICEF-yhdistys ry:lle maksettavista tekijänoikeuspalkkioista. ${ }^{139}$

138 Päätös mainitaan lyhyesti esim. teoksissa Andersson Tuloverotus ja varallisuusverotus (1995) s. 359 ja Andersson - Linnakangas - Frände Tuloverotus (2016) s. 432 sekä työ- ja elinkeinoministeriön raportissa TEM 30/2013 Tekijänoikeustulon kohtelu eri oikeussubjektien kannalta (tekijä Markus Myhrberg, Lexia Oy) s. 14.

139 Koska UNICEF-yhdistys ry on yleishyödyllinen yhteisö, se ei joudu maksamaan lahjaveroa. Yleishyödyllisten yhteisöjen verokohtelua käsitellään jäljempänä tarkemmin. 
KVL:n ratkaisu syntyi äänin 4-3. Vähemmistö katsoi, että jos A lahjoitti hakemuksessa tarkoitetulla tavalla UNICEF-yhdistys ry:lle tekijänoikeudet teoksiinsa X ja Y, ei A ollut verovelvollinen lahjakirjan allekirjoittamisen jälkeen UNICEF-yhdistys ry:lle maksettavista tekijänoikeuspalkkioista.

Puu ja hedelmät -oppiin liittyvistä ennakkopäätöksistä mainittakoon myös seuraava osinkojen verotusta koskeva ratkaisu:

KHO 25.10.1990 T 3642. A oli lahjoittanut omistamiensa X Oy:n osakkeiden tulevan tuoton elinajakseen eräälle yleishyödylliselle yhteisölle pidättäen itsellään omistusoikeuden osakkeisiin ja niiden suoman äänivallan. Koska A omisti osakkeet, joiden perusteella osingot oli maksettu, häntä oli myös näistä osinkotuloista verotettava.

\subsubsection{Henkilöyhtiöiden verotusaseman ja sivuuttamiskäytännön kehitys}

Avoimet yhtiöt ja kommandiittiyhtiöt sekä muutkin yhtymät olivat Suomessa erillisiä verovelvollisia $1970-$ luvun puoliväliin asti. Erillisverotus mahdollisti tulojen pilkkomisen usealle verovelvolliselle ja mahdollisti siten myös verosäästöä, kun verokanta oli progressiivinen. Monesti henkilöyhtiö sivuutettiin veronkiertämissäännöksen perusteella ja sen nimissä ilmoitettu tulo verotettiin omistajalla.

Vuoden 1994 lopussa säädetyssä tulo- ja varallisuusverolaissa erillisverotus säilytettiin kaupparekisteriin merkityillä liiketoimintaa harjoittavilla avoimilla yhtiöillä ja kommandiittiyhtiöillä. Tällaisia henkilöyhtiöitä saatettiin kuitenkin käytännössä yhä sivuuttaa veronkiertämissäännöksen nojalla.

Vuonna 1988 säädetyssä uudessa tulo- ja varallisuusverolaissa henkilöyhtiöille luotiin kompromissina hyvin erikoinen verotusasema. Uudessa järjestelmässä kaupparekisteriin merkitylle liiketoimintaa harjoittavalle avoimelle yhtiölle ja kommandiittiyhtiölle vahvistetusta verotettavasta tulosta jaettiin puolet verotettavaksi yhtiön tulona ja puolet yhtiömiesten tulona. Useimmissa tapauksissa verotus ei kiristynyt, ja eräissä tapauksissa puolittaminen merkitsi jopa verotuksen keventämistä. 
Vuonna 1993 voimaan tulleessa tuloverolaissa vasta luovuttiin erillisverotuksesta kokonaan avoimien yhtiöiden ja kommandiittiyhtiöiden verotuksessa. Siirryttiin osakasverotukseen; siinä yhtiö on laskentasubjekti, jonka tulot jaetaan verotettavaksi osakkailla. Siirtymävaiheessa oli käytössä myös ansiotulosta tehtävä yhtiömiesvähennys.

Henkilöyhtiöitä perustamalla ei enää saavuteta sellaisia veroetuja kuin aikaisemmin, joten myös tarve sivuuttaa henkilöyhtiöitä veronkiertämissäännöksen nojalla on merkittävästi vähentynyt, eikä uusia oikeustapauksia asiasta ole julkaistu aikoihin. Enää ei olekaan samaa tarvetta koko henkilöyhtiön sivuuttamiseen kuin aikaisemmin, mutta veronkiertämissäännöksellä voidaan puuttua myös yksittäisiin toimiin, esimerkiksi jotakin osakasta suosivaan voitonjakomääräykseen tai keinotekoisiin luontoisetu- yms. järjestelyihin.

\subsubsection{Taiteilijoiden osakeyhtiöt}

\subsubsection{Osakeyhtiön verotusaseman kehitys}

1920-luvuilla säädetyissä tulo- ja omaisuusverolaeissa osingot olivat kahdenkertaisen verotuksen piirissä, mutta tätä lievennettiin niin, että osakeyhtiöiden sallittiin vähentää verotettavasta tulostaan $50 \%$ jakamastaan osingosta. Osakeyhtiöitä verotettiin tässä vaiheessa soveltaen yleistä tuloveroasteikkoa.

Vuonna 1943 säädetyssä tulo- ja omaisuusverolaissa osakeyhtiöille säädettiin oma tasaverokanta, joka oli TOL:n alkuperäisen säännöksen mukaan 20 \%. Myöhemmin se oli korkeampi. Kahdenkertaisen verotuksen lieventäminen luonnollisten henkilöiden osalta alkoi vuonna 1956, jolloin tuli voimaan TOL 50 a $\$$. Tuon säännöksen mukaan, jota sovellettiin vuoteen 1971 saakka, verovelvollisen verosta vähennettiin $15 \%$ saadun osingon määrästä.

Vuosilta 1965 ja 1966 toimitetuissa valtionverotuksissa osakeyhtiön verokanta oli $48 \%$. Kahdenkertaisen verotuksen lieventämiseksi vero kuitenkin oli $42 \%$ siitä tulon osasta, joka vastasi jaettavaksi päätettyä osinkoa (vähennettynä yhtiön saamien verovapaiden osinkojen määrällä). Yhteisöjen verokanta valtionverotuksessa oli esimerkiksi vielä 1980-luvun alussa 43 \%. Yhteisöjenkin verokannassa oli pitkään progressiivisia piirteitä. Vielä vuonna 1992 oli voimassa 
tulo- ja varallisuuslain $148 \$$, jos yhteisön verotettava tulo oli alle $100000 \mathrm{mk}$.

Kunnallisverotuksessa yhtiöt olivat 1800-luvun lopulla verovelvollisia samalla tavalla kuin fyysiset henkilöt. Vuonna 1883 lakeihin otettiin nimenomainen säännös osingonsaajan verovelvollisuudesta osinkotuloistaan, vaikka yhtiötä olisi jo verotettu vastaavasta tulosta. Kunnallisverolait kumottiin vasta 1970 -luvulla voimaan tulleella tulo- ja varallisuusverolailla, jossa yhdistettiin valtionveroa ja kunnallisveroa koskevat säännökset.

Vuonna 1969 voimaan tuli EVL, johon otettiin säännökset osakeyhtiön valtionverotuksessa tehtävistä osingonjakovähennyksistä kahdenkertaisen verotuksen ongelman ratkaisemista varten. EVL 18 \$:n 4 kohdan mukaan vähennyskelpoista valtionverotuksessa oli $40 \%$ osakeyhtiön jakamasta osingosta, josta oli vähennetty verovapaat osingot. Vähennys oli 100 \% jaetusta osingosta, kun osinko jaettiin uudesta osakeyhtiöstä tai maksulliselle osakepääoman korotukselle.

Kun otettiin huomioon sekä valtion että kunnan tulovero, yhteisön verotettavan tulon veroprosentti saattoi nousta noin $60 \%$ :iin. Monessa tapauksessa syntyi myös kahdenkertaista verotusta osakkaan saamien osinkojen kanssa, jolloin kokonaisverotus saattoi nousta todella korkeaksi. Toisaalta esimerkiksi yleishyödyllisten yhteisöjen saamien osinkojen verovapaus johti usein siihen, ettei yhteenkään kertaan verottaminen toteutunut.

1980- ja 1990-lukujen vaihteessa meillä siirryttiin yhtiöveron hyvitysjärjestelmään, joka ratkaisi uudella tavalla osakeyhtiön ja sen osakkaan kahdenkertaisen verotuksen ongelman. Tässä järjestelmässä osingonsaajalla oli saamansa osingon perusteella oikeus yhtiöveron hyvitykseen ja hänen tulokseen luettiin osingon lisäksi yhtiöveron hyvityksen määrä. Yhtiön oli aina suoritettava tuloveroa jaettavaksi päätetyn osingon mukainen vähimmäismäärä. Näin vältettiin kahdenkertainen verotus mutta turvattiin yhdenkertainen verotus.

Yhtiöveron hyvitysjärjestelmästä jouduttiin luopumaan vuoden 2005 alusta erityisesti siksi, että sitä oli hankala soveltaa kansainvälisissä tilanteissa. Julkisesti noteeratusta yhtiöstä saadun osingon verokohtelusta säädetään nykyisin TVL 33 a \$:ssä; vuodesta 2014 alkaen, jolloin yhteisöjen tuloveroprosentti alennettiin $20 \%$ :iin, osingosta $85 \%$ on pääomatuloa ja $15 \%$ verovapaata tuloa. 
Muusta kuin julkisesti noteeratusta yhtiöstä saadun osingon verokohtelusta säädetään TVL 33 b:ssä, jota on muutettu useaan kertaan. Nykyisin tällaisesta yhtiöstä saadusta osingosta on $25 \%$ veronalaista pääomatuloa ja $75 \%$ verovapaata tuloa siihen määrään saakka, joka vastaa varojen arvostamisesta verotuksessa annetussa laissa tarkoitetulle osakkeen verovuoden matemaattiselle arvolle laskettua $8 \%$ :n vuotuista tuottoa. Siltä osin kuin verovelvollisen saamien tällaisten osinkojen määrä ylittää 150000 euroa, osingosta $85 \%$ on pääomatuloa ja $15 \%$ verovapaata tuloa. Mainitun vuotuisen koron ylittävältä osalta osingosta $75 \%$ on ansiotuloa ja $25 \%$ verovapaata tuloa. Osinko on ansiotuloa, jos osingon jakoperusteena yhtiöjärjestyksen määräyksen, yhtiökokouksen päätöksen, osakassopimuksen tms. sopimuksen mukaan on osingonsaajan tai tämän intressipiiriin kuuluvan henkilön työpanos. VML 29 \$:n mukaisesta peitellystä osingosta $75 \%$ on ansiotuloa ja $25 \%$ verovapaata tuloa (TVL $33 \mathrm{~d} \$$ ).

Seuraavassa oikeustapauksessa ei sovellettu veronkiertämissäännöstä vaan järjestely hyväksyttiin:

KHO 2008:6. Hakijoiden tarkoitus oli perustaa lääkäritoimintaa harjoittava osakeyhtiö. Lääkärit merkitsivät yhtiön osakkeet joko itse tai omistamansa holdingyhtiön kautta. Perustettavan yhtiön osakkeet jakautuivat kantaosakesarjaan ja useisiin vastaanotto-osakesarjoihin. Jokaiselle toimintaan mukaan tulevalle lääkärille oli yhtiössä oma vastaanotto-osakesarja. Yhtiöjärjestyksen märäyksen mukaan kunkin vastaanotto- ja kantaosakesarjan oikeus yhtiön varoihin määräytyi asianomaisen osakesarjan toimintatuloksen ja aikaisemmilta vuosilta jakamattomien toimintatulosten yhteismäärän mukaan. Kantaosakesarjan toimintatulos laskettiin hallinnointitoiminnosta, ja kunkin vastaanotto-osakesarjan toimintatulos laskettiin kyseisestä vastaanottotoiminnosta. Yhtiöjärjestyksen mukaan yhtiön laskentatoimi oli hoidettava siten, että kutakin osakesarjaa vastaava toimintatulos oli todennettavissa. Kun osingon peruste oli määrätty yhtiöjärjestyksessä eikä osakkailla ollut harkintavaltaa osingonjaon kohdistumisessa osakesarjojen kesken, yhtiön jakama osinko katsottiin, lainsäädännön senhetkinen tila huomioon ottaen, veronalaiseksi osinkotuloksi, joka verotettiin osingonsaajasta riippuen siten kuin TVL:ssa ja EVL:ssa säädettiin. Eri mieltä olleet jäsenet katsoivat, että järjestelyn siviilioikeudellisesta hyväksyttävyydestä huolimatta osakeyhtiölain mukaan osingoksi luokiteltava suoritus voitiin VML 28 \$:n säännös huomioon ottaen katsoa verotuksessa muunlaiseksi tuloksi varsinaisen luonteensa mukaisesti. 
Päätös olisi ollut omiaan lisäämään verosuunnittelutoimia lievän osinkoverotuksen hyödyntämiseksi, ja tätä haluttiin hillitä. Lainmuutoksella 26.6.2009/469 TVL 33 b §:ään lisättiin työpanososinkoja koskeva momentti. Sen estämättä, mitä muualla laissa säädetään osingon veronalaisuudesta, osinko on ansiotuloa, jos osingon jakoperusteena yhtiöjärjestyksen määräyksen, yhtiökokouksen päätöksen, osakassopimuksen tai muun sopimuksen mukaan on osingonsaajan tai tämän intressipiiriin kuuluvan henkilön työpanos. Osinko on tällöin sen tuloa, jonka työpanoksesta on kysymys. Säännöksen soveltaminen ei edellytä veronkiertämissäännöksen soveltamista. Työpanososinkosäännös koskee vain muun kuin julkisesti noteeratun yhtiön jakamaa osinkoa.

\subsubsection{Osakeyhtiöiden sivuuttamiskäytännön kehitys $^{140}$}

Oikeuskäytännössä osakeyhtiöitä alettiin verotuksessa sivuuttaa 1980-luvulta alkaen. Tyypillistä veronkiertämissäännöksen sivuutetuille osakeyhtiöille on ollut liikevaihdon suhteellisen pienuuden ohella se, että osakkaalle ei ole maksettu työn arvoa vastaavaa palkkaa, yhtiön omistuspohja on ollut erittäin suppea, palkattuja ulkopuolisia työntekijöitä ei ole ollut, toiminnassa on ollut kysymys henkilökohtaisista palveluista, pääoma on ollut pieni ja toimeksiantajia vähän. ${ }^{141}$ Oikeuskäytäntöä kuvaavat seuraavat ennakkopäätökset:

KHO 1981 II 597. Esiintyvä taiteilija oli esiintynyt mainosalan yhtiön lukuun kyseisen yhtiön tuottamassa, erään pankin tilaamassa mainoskampanjassa kuvauskohteena. Mainosalan yhtiö oli esiintymissopimuksen solmimista varten ottanut yhteyden taiteilijaan itseensä. Kuvausten päätyttyä oli sovitun korvauksen laskuttanut ohjelmatoimistoalan osakeyhtiö, jonka toimitusjohtaja ja hallituksen ainoa jäsen taiteilija oli. Korvaus oli laskutettu osakeyhtiön mainosalan yhtiölle tilauksesta valmistamasta mainoskampanjasta, johon sisältyivät TV-filmit, still-kuvat ja lehti- ym.

140 Tarkemmin Ala-Lahti-Kataja Osakeyhtiön sivuuttaminen veronkiertosäännöstä soveltamalla - tulkintaympäristön kehitys, Verotus 2020 (väitöskirja-artikkeli netissä).

141 Esim. Tunturi Miniosakeyhtiön sivuuttamisen veroseuraamukset, Verotus 1993 s. 433 ss. Tässä yhteydessä käytettiin mm. ilmauksia "näyttelijätapaukset", ”laulavat yhtiöt" ja "tanssivat osakeyhtiöt". 
mainonta. Palkkio katsottiin tosiasiassa maksetuksi EPL:n mukaisena palkkana taiteilijalle henkilökohtaisesti.

KHO 28.9.1982 T 4277. Esiintyvä taiteilija oli perustanut yhdessä vaimonsa ja kahden muun henkilön kanssa osakeyhtiön, jonka yhtiöjärjestyksen mukainen toimiala oli erilaisten viihdeohjelmien valmistus, levytys ja myynti. Yhtiön taiteilijan henkilökohtaisesta esiintymisestä erilaisilta yhteisöiltä laskuttamat ja kirjanpitoonsa sisällyttämät palkkiot katsottiin asiassa saatuun selvitykseen nähden taiteilijan itsensä tuloksi.

KHO 1994 B 549. Varatuomari A, joka oli ollut päätoimisesti erään korkeakoulun hallintojohtaja, oli sivutoimisesti työskennellyt liiketaloudellista ja juridista konsultointia harjoittavassa X Oy:ssä, jonka osakas hän oli. X Oy oli laskuttanut suorittamistaan konsultointitehtävistä Z Oy:ltä määriä, joihin sisältyi myös palkkiota siitä, että A oli toiminut hallituksen jäsenenä Z Oy:ssä. Z Oy:n X Oy:lle maksamista suorituksista se osa, joka asiakirjojen mukaan oli sovittu maksettavaksi A:n toimimisesta $Z$ Oy:n hallituksen jäsenenä, oli jälkiverotuksin lisätty A:n tuloon henkilökohtaisena palkkatulona. Lääninoikeus katsoi, ettei A:n ollut näytetty saaneen kysymyksessä olevia palkkioita Z Oy:n hallituksen jäsenenä. KHO puolestaan katsoi, että X Oy:lle maksetuista palkkioista oli osa A:n saamaa palkkaa toimimisesta Z Oy:n hallituksen jäsenenä. Tämän vuoksi $\mathrm{KHO}$ tarkastusasiamiehen valituksesta kumosi lääninoikeuden päätöksen ja saattoi voimaan A:ta kohdanneen valtionveron jälkiverotuksen. Ä̈̈nestys $3-2-2$.

Uudemmassa oikeuskäytännössä osakeyhtiöiden sivuuttamiseen suhtauduttiin varsin pidättyvästi (ks. esim. KHO 1997 T 155 ja KHO $1997 \mathrm{~T} \mathrm{1820).}{ }^{142}$

Osakeyhtiön sivuuttamista verotuksessa käsiteltiin laajasti verotuksen oikeusturvatyöryhmän 30.6.1997 päivätyssä välimuistiossa (VM 17/1997), jossa esitettiin ongelman ratkaisemista siten, että muu paitsi palkkatulo ja siihen rinnastettava siihen rinnastettava henkilökohtainen tulo voitaisiin ohjata osakeyhtiössä verotettavaksi. TVL 19 a §:ään olisi lisätty seuraava säännös:

Yhteisö on erillinen verovelvollinen. Yhteisön saamaa tuloa verotetaan yhteisön tulona. Palkkatuloa ja muuta siihen rinnastettavaa

142 Linnakangas - Immonen - Puronen Verotuskäytäntö 1997 s. 292 ss. ja Verotuskäytäntö 1998 s. 287 ss. 
henkilökohtaista tuloa, kuten palkkatulon sijaan saatua vakuutus- ja vahingonkorvausta, eläketuloa, urheilijan palkkiota, apurahaa tai sosiaalietuutta ei veroteta yhteisön tulona.

Työryhmän vähemmistö piti parempana mallia, jonka mukaan osakeyhtiömuodossa saatu elinkeinotoiminnan tulo verotettaisiin osakeyhtiön tulona. Työryhmä ei enää 9.1 .1998 valmistuneessa loppumietinnössään (VM 36/1997) käsitellyt osakeyhtiöiden sivuuttamista. Sen sijaan se pohti veronkiertämissäännöksen asemaa ja muutostarpeita. Työryhmä ei kuitenkaan esittänyt veronkiertämissäännöksen muuttamista vaan esitti soveltamiskäytännön seuraamista.

Hallitus antoi toukokuussa 1998 esityksen verotusmenettelylain muuttamiseksi (HE 53/1998). Esityksen perusteluissa käsiteltiin myös osakeyhtiöiden sivuuttamista koskevaa oikeuskäytäntöä ja todettiin (epätarkasti), että uudemmissa ratkaisuissa sivuuttamista ei ollut hyväksytty. Hallitus totesi lisäksi, että myös Verohallitus oli oikeusturvaongelmien vuoksi koulutuksessaan ohjeistanut hallintoa suhtautumaan pidättyvästi osakeyhtiöiden sivuuttamiseen.

Osakeyhtiöiden sivuuttamisen kategorinen kieltäminen olisi hallituksen mielestä korostanut pääomatulojen ja ansiotulojen verotukseen liittyviä ongelmia. Verosuunnittelupaine ansiotulojen muuttamiseksi pääomatuloiksi kasvaisi, mikä johtaisi ansiotulojen veropohjan rapautumiseen. Osakeyhtiöiden sivuuttamisen kieltäminen lainsäädäntöä muuttamalla ei hallituksen mielestä siten olisi ollut perusteltua. Sivuuttamiseen liittyviä oikeusturvaongelmia voitiin hallituksen mielestä vähentää lisäämällä verovelvolliselle annettavaa luottamuksensuojaa sekä määrittelemällä yhtiöiden verotuksellinen asema jo säännönmukaisen verotuksen yhteydessä.

Kokonaan osakeyhtiöiden sivuuttamisesta ei ole myöhemminkään luovuttu, kuten seuraavat oikeustapaukset osoittavat:

KHO 1999 T 2430. Liikealan erikoisoppilaitos oli tehnyt liiketaloustieteen koulutus- ja konsultointipalveluja tuottavan yhtiön kanssa sopimuksen, jonka mukaan yhtiö järjesti oppilaitokselle liiketalouden kursseja, jotka liittyivät oppilaitoksen järjestämään merkonomin tutkintoon. Koulutustehtävät sisälsivät kurssien opintomateriaalin laadinnan, etätehtävien laadinnan ja tarkastuksen, lähiopetuksen ja puhelinopetuksen. Opetus suoritettiin monimuoto-opetuksena, ja kursseihin liittyvä luento-opetus 
tapahtui oppilaitoksen tiloissa. Toimeksiannosta suoritettava korvaus maksettiin yhtiölle oppilaitoksen lukuvuosittain määrittämien perusopetuksen maksuperusteiden mukaan kunkin opintojakson päätyttyä. Kursseihin sisältyvät koulutustehtävät suoritti pääasiassa yhtiön osakas, joka oli koulutukseltaan kauppatieteiden maisteri ja toimi kokopäivätyössä oppilaitoksessa. KHO katsoi, että oppilaitoksen yhtiölle suorittamat koulutuspalkkiot olivat EPL 13 §:ssä tarkoitettua palkkaa. Veroasiamiehen valituksesta lääninoikeuden päätös, jossa oli katsottu, että kysymys oli EPL 25 \$:n mukaisesta työkorvauksesta, kumottiin.

KHO 2004:5. A antoi kieltenopetusta kansalaisopistossa. Hänen opetustuntiensa määrä lukukautena 2000-2001 oli 152 tuntia. Kansalaisopisto maksoi palkkion A:n opetustyöstä ennakkoperintärekisteriin merkitylle $\mathrm{X}$ Oy:lle, jonka osakas, toimitusjohtaja ja hallituksen ainoa varsinainen jäsen A oli. Kansalaisopiston vuotuinen opetussuunnitelma muodostui opettajien laatimista opetussuunnitelmista. Myös A:n opetus perustui hänen itsensä laatimaan opetussuunnitelmaan. A:n opetustyöskentely tapahtui opiston toimitiloissa ja laitteilla, eikä se poikennut opistoon normaalissa työsuhteessa olevien opettajien toiminnasta. Näissä oloissa kansalaisopiston X Oy:lle suorittamat opetuspalkkiot eivät olleet EPL 25 \$:ssä tarkoitettua työkorvausta vaan EPL 13 \$:ssä tarkoitettua palkkaa, josta oli toimitettava ennakonpidätys ja jonka perusteella oli suoritettava työnantajan sosiaaliturvamaksu.

Verohallinnon uusimmissa ohjeissa (2.8.2016) todetaan veronkiertämissäännöksen soveltamisesta osakeyhtiöiden sivuuttamiseen mm. seuraavaa:

Jos työn suorittaja toimii yleensä yrittäjänä, ei kuitenkaan ole tarkoituksenmukaista kohdistaa yksittäisestä ja tulkinnanvaraisesta toimeksiannosta osakeyhtiölle maksettua korvausta osakkaalle etenkään silloin, jos toimeksiannon taloudellinen merkitys on vähäinen. Tulkinnanvaraisen suorituksen uudelleen kohdistaminen ei ole tarkoituksenmukaista myöskään silloin, kun osakeyhtiötä on verotettu sen saamasta tulosta ja yhtiö on maksanut kaikki veronsa (ennakot, lopullisen veron, arvonlisäveron). 


\subsubsection{Tekijänoikeustuloja koskevaa oikeuskäytäntöä}

Tekijänoikeustulojen henkilöllisestä kohdistamisesta ja veronkiertämissäännöksen soveltamisesta on seuraava julkaistu KHO:n päätös: ${ }^{143}$

KHO 24.11.2000 T 3033. Liikeyritysten ja maatalousyritysten talouden ja verotuksen konsultointia ja koulutusta sekä sijoitustoimintaa toimialanaan harjoittava osakeyhtiö oli ilmoittanut verovuoden 1995 tuloinaan sijoitustoiminnan tulojen ja lausunto- ja konsultointipalkkioiden lisäksi tekijänoikeuspalkkioita. KHO myönsi veroasiamiehelle valitusluvan siltä osin kuin asiassa oli kysymys siitä, oliko yhtiön tuloon verotuksessa luetut tekijänoikeuspalkkiot katsottava yhtiön pääosakkaan tuloksi.

Yhtiölle oli maksettu tekijänoikeuspalkkioita kustantajan ilmoituksen mukaan $40000 \mathrm{mk}$ vuonna 1994, 74 254,30 mk vuonna 1995, 127933,30 mk vuonna 1996 ja 138 808,20 mk vuonna 1997 eli yhteensä 380 995,80 mk vuosina 1994-1997. Kyseiset tekijänoikeuspalkkiot sisältyivät yhtiön konsultointitoiminnasta ilmoittamaan tuloon seuraavasti: 40000 mk verovuoden 1995 yhteensä 342700 mk:n konsultointituloon, 74254 mk verovuoden 1996 yhteensä 700041 mk:n konsultointituloon ja $266741 \mathrm{mk}$ verovuoden 1997 yhteensä 543828 mk:n konsultointituloon.

Tekijänoikeuspalkkiot oli maksettu jatkuvatäydenteisestä tietoteoksesta, jonka tekijä ja ajantasaistaja oli yhtiön pääosakas. Esitettyjen selvitysten mukaan tekijänoikeuspalkkioiden hankinnassa oli jossain määrin käytetty avustajia. Toimintaansa varten yhtiöllä ei ollut toimitiloja eikä ennen verovuotta 1997 käyttöomaisuutta, eikä yhtiötä ollut markkinoitu.

Tekijänoikeus oli kirjallisen teoksen luojalle kuuluva oikeus ja perustui siten tekijän henkilökohtaiseen osaamiseen ja pätevyyteen. Yhtiön tuloon luettujen tekijänoikeuspalkkioiden perusteena olevan teoksen tekijänoikeus kuului yhtiön pääosakkaalle, eikä tekijänoikeuteen liittyviä taloudellisia oikeuksia ollut selvitetty siirretyn yhtiölle. Ko. tekijänoikeuspalkkioiden hankinnassa osakeyhtiömuoto ei ollut tarpeen, eikä yhtiön toiminnan harjoittaminen tekijänoikeuspalkkioiden osalta ollut muutenkaan tapahtunut toiminnan laajuuden ja julkisuuden osalta sellaisessa muodossa, että tekijänoikeuspalkkioiden kohdistamiseen yhtiölle olisi ollut perusteita. Näin ollen yhtiön pääosakas on ollut tekijänoikeuspalkkioiden oikea tulonsaaja. Näillä perusteilla KHO katsoi, että yhtiön pääosakkaan tekijänoikeuteen perustuvien palkkioiden ilmoittaminen yhtiön verovuoden 1995 tulona ei vastannut asian varsinaista luonnetta

143 Tarkemmin Linnakangas KHO:n oikeustapausselostuksia, Tekijänoikeuspalkkioiden henkilöllinen kohdistaminen - veron kiertäminen, Verotus 2001 s. 436444. 
ja tarkoitusta ja, ottaen huomioon verotuslain 56 \$:n (nyk. VML $28 \$$ ) säännöksen, kumosi lääninoikeuden ja verotuksen oikaisulautakunnan päätökset ja yhtiön verotuksen tekijänoikeuspalkkioiden osalta sekä palautti asian verovirastolle verotuksen uudelleen toimittamista varten.

Myös seuraava KHO:n julkaisematon ratkaisu koski sitä, verotetaanko tekijänoikeustuloista taiteilijaa vai hänen yhtiötään. ${ }^{144}$

KHO 14.2.2003 T 342. Säveltäjäin Tekijänoikeustoimisto Teosto r.y. ja B olivat 1.4.1993 solmineet säveltämistä ja sovittamista koskevan sopimuksen siitä, että Teosto sai sopimuksella kunkin teoksen luovuttamisajankohdasta lukien yksinomaisen oikeuden teosten julkiseen esittämiseen sekä vuokraamiseen ja muuhun saattamiseen yleisön saataviin, yksinomaisen oikeuden teosten tallentamiseen ääni- ja kuvanauhalle, ääni- tai kuvalevylle ja muulle laitteelle, jolla ne voitiin toisintaa; sekä yksinomaisen oikeuden vastaanottaa, säilyttää ja tilittää asiakkaalle tekijänoikeuslainsäädännön nojalla tulevia tyhjäkasetti- ja muita vastaavia korvauksia. Kysymyksessä oli asiakkaan Teostolle luovuttamien oikeuksien hallinnointi. Tämän sopimuksen perusteella B sai tekijänoikeuskorvauksia.

B omisti A Oy:n koko osakekannan. Yhtiön toiminta oli alkanut varsinaisesti keväällä 1998 siten, että liikevaihdostakin ensin suurempi osa syntyi esiintymisistä ja pienempi osa musiikkikappaleiden uudelleensovituksista. Myöhemmin uudelleensovitustyön osuus oli kasvanut, minkä lisäksi yhtiö oli ryhtynyt harjoittamaan levy-yhtiötoimintaa ja uusien musiikkikappaleiden tuottamistoimintaa. Harjoittamaansa toimintaa varten yhtiöllä oli käyttöomaisuutena musiikintekolaitteita ja mm. vuokratut studiotilat. Yhtiön tähän toimintaan oli kohdistunut palkkamenoja ja ulkopuolisten palvelujen käyttämisestä aiheutuneita menoja. Vuonna 2001 yhtiön liikevaihto oli n. 10 miljoonaa mk, yhtiön maksamat palkkamenot n. 500000 mk ja yhtiön alihankkijoille maksamat korvaukset n. $850000 \mathrm{mk}$. B oli nostanut yhtiöstä osinkoa esim. vuodelta $2001 \mathrm{n}$. $600000 \mathrm{mk}$.

Yhtiöllä oli vuonna 2001 kaksi päätoimista työntekijää: B ja hänen puolisonsa. B:n rahapalkka oli 10000 mk kuukaudessa ja puolisonsa palkka 13500 mk kuukaudessa. Työsopimuksessa oli todettu, että työntekijän työ oli sellaista, jonka tuloksena syntyvät immateriaalioikeudet mukaan lukien tekijänoikeudet siirtyivät ilman eri korvausta työnantajalle.

144 Päätös mainitaan myös tämän kirjan liitteenä olevassa Verohallinnon 28.9.2018 antamassa ohjeessa (dnro A120/200/2018). 
B oli tehnyt luovan sävellystyön yksin tai yhdessä eräiden muiden artistien kanssa. Näiden sävellystöiden perusteella hän oli saanut tekijänoikeuskorvauksia esimerkiksi vuonna 2001 noin 2 miljoonaa mk.

KHO totesi, että veronkiertämistä koskevan VML 28 \$:n edellytyksiä arvioitaessa oli kiinnitettävä huomiota B:n ja hänen kokonaan omistamansa yhtiön välisten sopimusten ehtoihin sen suhteen, voitiinko niiden katsoa olevan sellaiset, jollaisista toisistaan riippumattomat tahot yleensä keskenään vastaavanlaisessa tilanteessa sopivat. VML 28 \$:ää yleensä sovellettiin, jos vastike poikkesi tavanomaisesta, sopijapuolten välillä vallitsi intressiyhteys eikä hintapoikkeamaa voitu selittää hyväksyttävillä taloudellisilla syillä ja toimenpiteeseen oli ryhdytty verosta vapautumisen tarkoituksessa.

$\mathrm{B}$, jonka säveltämät musiikkikappaleet olivat tuottaneet huomattavan suuria tekijänoikeuskorvauksia, oli kirjallisen työsopimuksen solmimisen jälkeen ilman erillistä korvausta siirtänyt yhtiölle työnsä tuloksena syntyneet tekijänoikeuskorvaukset. B oli nostanut yhtiöstä varsin vaatimatonta rahapalkkaa. Palkan määrässä ei ollut otettu huomioon hänen tuotantonsa tulosta eikä hänen ilman erillistä korvausta tapahtunutta luopumistaan tekijänoikeuksista. B:n yhtiöstä nostaman palkan määrä ei ollut sillä tasolla, jota hän ilmeisesti olisi vaatinut vastaavanlaisen sävellystyön tekemisestä ulkopuoliselle työnantajalle. Vastikkeen määrää arvioitaessa maksettujen osinkojen suurella määrällä ei ollut merkitystä. B:n ja yhtiön välisen sopimuksen ehdot olivat näin ollen tavanomaisesta poikkeavat. Luovassa sävellystyössä ei ollut käytetty ulkopuolisia avustajia, joille olisi maksettu palkkoja tai palkkioita. Näissä oloissa, kun sävellystyö perustui B:n henkilökohtaiseen luovaan työhön, liiketaloudellisia perusteita siirtää tekijänoikeudet ennakkoratkaisuhakemuksessa selostetulla työsopimuksella yhtiölle ei ollut olemassa. KHO katsoi, että hakemuksessa tarkoitetut tulot eivät olleet $\mathrm{A}$ Oy:n vaan B:n veronalaista tekijänoikeustuloa.

\subsubsection{Tekijänoikeuksien luovutus määräajaksi musiikintekijän yhtiölle}

Vuoden 2017 alussa tuli voimaan laki tekijänoikeuden yhteishallinnosta (1494/2016). Laki perustuu hallituksen esitykseen 119/2016. Kyseisellä lailla on pantu täytäntöön Euroopan parlamentin ja neuvoston direktiivi 2014/26/EU tekijänoikeuden ja lähioikeuksien kollektiivisesta hallinnoinnista sekä usean valtion alueen kattavasta musiikkiteosten oikeuksien lisensioinnista verkkokäyttöä varten sisämarkkinoilla.

Lakiin sisältyvät säännökset mm. oikeudenhaltijoiden oikeuksista suhteessa yhteishallinnointiorganisaatioon, jäsenten oikeuksista 
ja päätösvallasta sekä jäsenten ja oikeudenhaltijoiden etujen valvonnasta yhteishallinnointiorganisaatiossa, tekijänoikeuskorvausten hallinnoinnista, oikeuksien hallinnoinnista muiden yhteishallinnointiorganisaatioiden puolesta, yhteishallinnointiorganisaation suhteesta käyttäjiin sekä yhteishallinnoinnissa noudatettavasta avoimuudesta ja tiedonantovelvollisuudesta.

Lain tavoitteena on $1 \$$ :n mukaan turvata tekijänoikeuden ja lähioikeuksien oikeudenhaltijoiden itsemääräämisoikeus, edistää tekijänoikeusmarkkinoiden toimivuutta sekä varmistaa, että tekijänoikeuden ja tekijänoikeuden lähioikeuksien yhteishallinnoinnissa toimitaan vastuullisesti, tehokkaasti ja läpinäkyvästi suhteessa oikeudenhaltijoihin ja käyttäjiin. Yhteishallinnointiorganisaatiolla tarkoitetaan 4 \$:n 1 kohdan mukaan oikeushenkilöä, joka on jäsentensä omistuksessa tai määräysvallassa tai on voittoa tavoittelematon, ja jonka ainoana tai pääasiallisena tarkoituksena on siihen valtuutettuna hallinnoida tekijänoikeutta tai tekijänoikeuden lähioikeuksia oikeudenhaltijoiden yhteiseen lukuun. Oikeudenhaltijalla tarkoitetaan 4 \$:n 4 kohdan mukaan sellaista luonnollista henkilöä tai oikeushenkilöä, jolla on hallussaan tekijänoikeus tai lähioikeus taikka jolla on oikeuksien hyödyntämistä koskevan sopimuksen tai lainsäädännön nojalla oikeus osuuteen tekijänoikeuskorvauksista; oikeudenhaltijana ei kuitenkaan pidetä yhteishallinnointiorganisaatiota.

Opetus- ja kulttuuriministeriö, työ- ja elinkeinoministeriö sekä sosiaali- ja terveysministeriö asettivat 13.12.2016 työryhmän tekemään ehdotuksia luovien alojen vahvistamiseksi Suomessa. Työryhmän 12.4.2017 päivätyssä julkaisussa (Opetus- ja kulttuuriministeriön julkaisuja 2017:18) asetettiin tavoitteeksi, että luovilla aloilla, esimerkiksi musiikin alalla, on oltava mahdollisuus toimia elinkeinonharjoittajana samoin edellytyksin kuin muissakin elinkeinoissa. Julkaisussa esitettiin mm., että Verohallinto laatii ohjeet tekijänoikeuksien siirtämiseen liittyvistä kysymyksistä tilanteessa, jossa tekijä luovuttaa tekijänoikeutensa omistamalleen yritystoimintaa harjoittavalle yritykselle. Myös Juha Sipilän hallituksen 28.4.2017 pidetyn puoliväliriihen kirjausten mukaan luovien alojen tekijänoikeuksien luovuttamiseen ja arvostamiseen liittyvät verotuskäytännöt olisi yhtenäistettävä, jolloin tekijänoikeudet ja niistä syntyvä tulo olisi mahdollista siirtää yhtiölle. Yhtiön käyttäminen on usein edellytyksenä 
kansainvälisissä liikesuhteissa ja perusteltua esimerkiksi asiakkuuksien hoitamisen, laskutuksen, toiminnassa tarvittavan kaluston hankinnan ja hallinnoinnin kannalta sekä muiden immateriaalioikeuksien hallinnoimiseksi.

Verohallinto on 28.9.2018 antanut ohjeen (dnro A120/200/2018) Tekijänoikeuksien yksinomaisen käyttöoikeuden luovuttaminen määräajaksi musiikintekijän yhtiölle. Tuo erittäin yksityiskohtainen ja monin esimerkein varustettu ohje on sellaisenaan tämän kirjan liitteenä. ${ }^{145}$ Ohjeessa käsitellään tekijänoikeuksien käyvän arvon määrittämistä ja verotusta silloin, kun musiikintekijä määräajaksi myöntää omistamalleen osakeyhtiölle yksinomaisen käyttöoikeuden tekijänoikeuden yhteishallinnoinnista annetun lain soveltamisalaan kuuluviin oikeuksiin ja korvauksiin. Ohje ei koske muiden kuin mainitun lain soveltamisalaan kuuluvien tekijänoikeuksien luovuttamista musiikintekijän yhtiölle.

\subsection{Taiteilijoiden kansainvälinen tuloverotus $^{146}$}

\subsubsection{Kaksinkertaisesta verotuksesta ja vajaaverotuksesta}

Useimpien valtioiden soveltamat asuinvaltioperiaate ja lähdevaltioperiaate johtavat kaksinkertaiseen verotukseen, jolloin eri valtioiden verotusvaateet kohdistuvat samaan tuloon. Kaksinkertaista verotusta voidaan poistaa kansallisella lainsäädännöllä ja verosopimuksilla.

Kansainvälinen kaksinkertainen verotus on ollut ongelma myös taiteilijoilla. Esimerkiksi Mika Waltarin (1908-1979) kerrotaan

145 Tämä ohje on poikkeuksellisen perusteellinen. Ohjeen valtuutussäännöksenä mainitaan Verohallinnosta annetun lain $2.2 \$$. Sen mukaan "Verohallinnon on edistettävä oikeaa ja yhdenmukaista verotusta sekä kehitettävä Verohallinnon palvelukykyä”. On korostettava, että kyseinen Verohallinnon ohje ei ole sitova, mutta sen mukaan toimiva saa luottamuksensuojaa verotuksessa.

146 Kansainvälisestä verotuksesta yksityiskohtaisesti esim. Helminen Kansainvälinen verotus (2016) ja Malmgrén - Myrsky Kansainvälinen henkilö- ja yritysverotus (2017). 
joutuneen sen kohteeksi saatuaan Sinuhe-tuloja USA:sta, ja kerrotaan, että hänen ansiostaan kaksoisverotus korjattiin. ${ }^{147}$ Ensimmäinen tuloverosopimus Suomen ja USA:n välillä solmittiin vuonna 1970. Nykyisin verosopimusverkosto on jo varsin kattava, ja kaksinkertaista verotusta estetään myös monilla kansallisilla verosäännöksillä.

Tunnetaan myös ilmiö, jota kutsutaan kansainväliseksi vajaaverotukseksi. Siinä mikään valtio ei verota tai veroseuraamukset ovat hyvin vähäiset. Tunnetut taiteilijat ja urheilijat ovat julkisuuden henkilöitä, joiden verovälttely usein saa suurta huomiota mediassa. Yhtenä verovälttelyn muotona on käytetty asumista sellaisessa valtiossa, jossa tuloverotus on alhainen. Toinen keino on ollut tulojen ohjaaminen verokeitaisiin perustettuihin yhtiöihin, johon usein on liittynyt myös tulolaadun muuntaminen ja palvelujen markkinaehtoisesta hinnoittelusta poikkeaminen.

Taiteilijoiden kaksinkertaista verotusta ja vajaaverotusta pyritään estämään kansallisesti ja kansainvälisesti monella tapaa, kuten seuraavassa selvitetään.

\subsubsection{Verotusvaltion määräytyminen}

\subsubsection{Kansallinen lainsäädäntö ja verosopimukset}

Velvollinen suorittamaan veroa tulon perusteella on (TVL $9 \$$ ):

1) verovuonna Suomessa asunut henkilö, kotimainen yhteisö, ulkomailla perustettu tai rekisteröity yhteisö, jonka tosiasiallinen johtopaikka sijaitsee Suomessa, yhteisetuus ja kuolinpesä täältä ja muualta saamastaan tulosta (yleinen verovelvollisuus);

2) henkilö, joka verovuonna ei ole asunut Suomessa, sekä muu kuin 1 kohdassa tarkoitettu ulkomainen yhteisö täältä saamastaan tulosta (rajoitettu verovelvollisuus).

Suomesta saatua tuloa on TVL 10 \$:n mukaan mm.:

- täällä harjoitetusta liikkeestä, ammatista, maataloudesta tai metsätaloudesta saatu tulo;

- palkkatulo, jos työ, tehtävä tai palvelus on yksinomaan tai pääasiallisesti suoritettu Suomessa täällä olevan työn- tai toimeksiantajan lukuun;

147 www.panurajala.fi/puheita/mika-waltari (19.9.2008). 
- tulo, joka on saatu taiteilijan tai urheilijan Suomessa tai suomalaisessa aluksessa harjoittamasta henkilökohtaisesta toiminnasta;

- rojalti, lisenssimaksu ja muu niihin rinnastettava hyvitys, jos hyvityksen perusteena olevaa omaisuutta tai oikeutta käytetään elinkeinotoiminnassa täällä tai jos hyvityksen maksamiseen velvollinen on Suomessa asuva henkilö tai suomalainen yhteisö, yhtymä, yhteisetuus tai kuolinpesä.

Henkilön katsotaan TVL 11 \$:n mukaan asuvan Suomessa, jos hänellä on täällä varsinainen asunto ja koti tai jos hän jatkuvasti oleskelee täällä yli kuuden kuukauden ajan, jolloin tilapäinen poissaolo ei estä pitämästä oleskelua jatkuvana. Suomen kansalaista pidetään kuitenkin Suomessa asuvana, vaikka hän ei jatkuvasti oleskelekaan täällä yli kuuden kuukauden aikaa, kunnes kolme vuotta on kulunut sen vuoden päättymisestä, jonka aikana hän on lähtenyt maasta, jollei hän näytä, että hänellä ei ole verovuonna ollut olennaisia siteitä Suomeen. Jollei muuta näytetä, Suomen kansalaisen ei katsota mainitun ajan jälkeen asuvan Suomessa.

Suomella on tuloverotusta koskeva verosopimus noin 80 valtion kanssa. Kaikki verosopimukset ovat yksilöllisiä eri valtioiden välillä solmittuja sopimuksia. Suomen verosopimukset perustuvat pitkälti OECD:n malliverosopimukseen (nykyinen malli vuodelta 2017). Sopimuksissa määrätään, miten verotusoikeus jakautuu sopijavaltioiden kesken.

Verosopimuksissa on yleensä erilliset artiklat mm. liiketuloa, osinkoa, korkoa, rojalteja, luovutusvoittoa ja työtuloa varten sekä vielä erikseen taiteilijoita ja urheilijoita varten. Tämän tutkimuksen kannalta erityisen kiinnostuksen kohteena ovat taiteilijoita sekä rojalteja koskevat artiklat. Niitä käsitelläänkin seuraavaksi.

\subsubsection{Taiteilija-artikla verosopimuksissa}

Viihdetaiteilijoita koskee OECD:n malliverosopimuksen 17 artikla, joka kuuluu englanniksi näin:

\section{ENTERTAINERS AND SPORTSPERSONS}

1. Notwithstanding the provisions of Article 15, income derived by a resident of a Contracting State as an entertainer, such as a theatre, motion picture, radio or television artiste, or a musician, or as a sportsperson, 
from that resident's personal activities as such exercised in the other Contracting State, may be taxed in that other State.

2. Where income in respect of personal activities exercised by an entertainer or a sportsperson acting as such accrues not to the entertainer or sportsperson but to another person, that income may, notwithstanding the provisions of Article 15, be taxed in the Contracting State in which the activities of the entertainer or sportsperson are exercised.

Tulosta, jonka sopimusvaltiossa asuva henkilö saa viihdetaiteilijana, kuten teatteri- tai elokuvanäyttelijänä, radio- tai televisiotaiteilijana tahi muusikkona, toisessa sopimusvaltiossa harjoittamastaan henkilökohtaisesta toiminnasta, voidaan siis verottaa tässä toisessa valtiossa sen estämättä, mitä sopimuksessa sanotaan liiketulosta ja työtulosta. Sama koskee sellaista tuloa, joka saadaan viihdetaiteilijan harjoittamasta henkilökohtaisesta toiminnasta ja joka ei tule viihdetaiteilijalle itselleen vaan toiselle henkilölle.

Joissakin verosopimuksissa, esimerkiksi Saksan kanssa tehdyssä, on määräys, jonka mukaan edellä mainittua taiteilija-artiklaa ei sovelleta tuloon, joka saadaan taiteilijan toiminnasta, jos hänen vierailunsa on kokonaan tai pääasiallisesti rahoitettu toisen sopimusvaltion taikka sen osavaltion tai paikallisviranomaisen varoista; tällöin sovelletaan liiketuloa ja työtuloja koskevia artikloja.

Erikoinen on USA:n kanssa tehdyn verosopimuksen 17 artikla:

Taiteilijat ja urheilijat

1. Tämän sopimuksen 14 artiklan (Itsenäinen ammatinharjoittaminen) ja 15 artiklan (Yksityinen palvelus) määräysten estämättä voidaan tulosta, jonka sopimusvaltiossa asuva henkilö saa taiteilijana, kuten teatteritai elokuvanäyttelijänä, radio- tai televisiotaiteilijana tahi muusikkona, taikka urheilijana, toisessa sopimusvaltiossa harjoittamastaan henkilökohtaisesta toiminnasta, verottaa tässä toisessa valtiossa paitsi milloin taiteilijan tai urheilijan tästä toiminnasta saaman kokonaistulon määrä, siihen luettuna menot, jotka on korvattu hänelle tai maksettu hänen puolestaan, ei kalenterivuoden aikana ylitä kahtakymmentätuhatta Yhdysvaltojen dollaria (\$20.000) tai sen vasta-arvoa Suomen rahana.

2. Milloin tulo, joka saadaan taiteilijan tai urheilijan tässä ominaisuudessaan harjoittamasta henkilökohtaisesta toiminnasta, ei tule taiteilijalle tai urheilijalle itselleen vaan toiselle henkilölle, voidaan tämän henkilön tulosta, 7 artiklan (Liiketulo) ja 14 artiklan (Itsenäinen ammatinharjoittaminen) määräysten estämättä, verottaa siinä sopimusvaltiossa, 
jossa taiteilija tai urheilija harjoittaa toimintaansa, jollei voida näyttää toteen, ettei taiteilijalla tai urheilijalla eikä häneen etuyhteydessä olevalla henkilöllä millään tavalla, ei välittömästi eikä välillisesti, ole osuutta tämän toisen henkilön tuloon, siihen luettuna lykätyn hyvityksen, bonuksen, palkkion, osingon, yhtymän voitonjaon tai muun voitonjaon vastaanotto.

USA:n kanssa tehdyssä verosopimuksessa 17 artiklan mukainen verotus esiintymismaassa edellyttää siis 20000 dollarin tulorajan ylitystä.

\subsubsection{Rojaltit}

OECD:n malliverosopimuksen 12 artikla koskee rojalteja:

\section{ROYALTIES}

1. Royalties arising in a Contracting State and beneficially owned by a resident of the other Contracting State shall be taxable only in that other State.

2. The term "royalties" as used in this Article means payments of any kind received as a consideration for the use of, or the right to use, any copyright of literary, artistic or scientific work including cinematograph films, any patent, trade mark, design or model, plan, secret formula or process, or for information concerning industrial, commercial or scientific experience.

3. The provisions of paragraph 1 shall not apply if the beneficial owner of the royalties, being a resident of a Contracting State, carries on business in the other Contracting State in which the royalties arise through a permanent establishment situated therein and the right or property in respect of which the royalties are paid is effectively connected with such permanent establishment. In such case the provisions of Article 7 shall apply.

4. Where, by reason of a special relationship between the payer and the beneficial owner or between both of them and some other person, the amount of the royalties, having regard to the use, right or information for which they are paid, exceeds the amount which would have been agreed upon by the payer and the beneficial owner in the absence of such relationship, the provisions of this Article shall apply only to the last-mentioned amount. In such case, the excess part of the payments shall remain taxable according to the laws of each Contracting State, due regard being had to the other provisions of this Convention. 
Esimerkiksi Saksan kanssa vuonna 2017 tehdyssä verosopimuksessa on seuraava 12 artikla, joka koskee rojaltituloja:

\section{Rojalti}

1. Rojaltista, joka kertyy sopimusvaltiosta ja jonka etuudenomistaja on toisessa sopimusvaltiossa asuva henkilö, verotetaan vain tässä toisessa valtiossa.

2. Sanonnalla "rojalti" tarkoitetaan tässä artiklassa kaikkia suorituksia, jotka saadaan korvauksena kirjallisen, taiteellisen tai tieteellisen teoksen (siihen luettuina elokuvafilmi sekä televisio- tai radiolähetyksessä käytettävä filmi tai nauha) tekijänoikeuden, patentin, tavaramerkin, mallin tai muotin, piirustuksen, salaisen kaavan tai valmistusmenetelmän käytöstä tai käyttöoikeudesta, taikka kokemusperäisestä teollis-, kaupallis- tai tieteellisluonteisesta tiedosta.

3. Tämän artiklan 1 kappaletta ei sovelleta, jos sopimusvaltiossa asuva rojaltietuuden omistaja harjoittaa toisessa sopimusvaltiossa, josta rojalti kertyy, liiketoimintaa siellä olevasta kiinteästä toimipaikasta, ja rojaltin maksamisen perusteena oleva oikeus tai omaisuus tosiasiallisesti liittyy tähän kiinteään toimipaikkaan. Tässä tapauksessa sovelletaan 7 artiklaa.

4. Jos rojaltin määrä maksajan ja rojaltietuuden omistajan tai heidän molempien ja muun henkilön välisen erityisen suhteen vuoksi ylittää rojaltin maksamisen perusteena olevaan käyttöön, oikeuteen tai tietoon nähden määrän, josta maksaja ja rojaltietuuden omistaja olisivat sopineet, jollei tällaista suhdetta olisi, tätä artiklaa sovelletaan vain viimeksi mainittuun määrään. Tässä tapauksessa verotetaan tämän määrän ylittävästä maksun osasta kummankin sopimusvaltion lainsäädännön mukaan, ottaen huomioon tämän sopimuksen muut määräykset.

Vuonna 2004 tuli voimaan lähiyhtiöiden välisiin rojaltimaksuihin liittyvä direktiivi 2003/49/EY, joka estää lähdeveron perimisen lähiyhtiöiden välisistä rojalteista. Direktiivissä tarkoitettuja rojalteja ovat mm. maksut, jotka saadaan vastikkeeksi kirjallisen tai taiteellisen teoksen, mukaan lukien elokuvien ja tekijänoikeuden, käytöstä. Direktiivin takaamia etuja ei tarvitse myöntää siltä osin kuin rojalti ylittää markkinaehtoisen määrän. Tuon direktiivin pohjalta lähdeverolakiimme on otettu seuraavat säännökset: 
3 a $\$$

Jäljempänä 3 b-3 e \$:ssä:

1) korolla tarkoitetaan tuloa velkasaatavista, riippumatta siitä, onko niiden vakuutena kiinnitys ja liittyykö niihin oikeus osuuteen velallisen voitosta, ja erityisesti arvopaperien tuottoa ja joukkovelkakirjojen tai obligaatioiden tuottoa mukaan lukien tällaisiin arvopapereihin, joukkovelkakirjoihin tai obligaatioihin liittyvät emissiovoitot ja palkkiot; maksun viivästymisen johdosta maksettavia sakkomaksuja ei pidetä korkoina;

2) rojaltilla tarkoitetaan maksuja, jotka saadaan vastikkeeksi kirjallisen, taiteellisen tai tieteellisen teoksen, mukaan lukien elokuvien ja tietokoneohjelmien, tekijänoikeuden, patentin, tavaramerkin, mallin, suunnitelman, salaisen kaavan tai menetelmän käytöstä tai käyttöoikeudesta taikka teollis-, kaupallis- tai tieteellisluonteisesta kokemusperäisestä tiedosta; myös maksut teollisten, kaupallisten tai tieteellisten laitteiden käytöstä tai käyttöoikeudesta katsotaan rojalteiksi.

$3 \mathrm{~b} \$$

Lähdeveroa tai lopullisessa verotuksessa kannettavaa veroa ei ole suoritettava korosta ja rojaltista edellyttäen, että:

1) koron ja rojaltin tosiasiallinen edunsaaja on toisesta Euroopan unionin jäsenvaltiosta oleva yhtiö tai jostakin jäsenvaltiosta olevan yhtiön toisessa jäsenvaltiossa sijaitseva kiinteä toimipaikka; ja

2) yhtiö, joka on koron tai rojaltin maksaja tai jonka kiinteän toimipaikan katsotaan olevan maksaja, on etuyhteydessä yhtiöön, joka on kyseisen koron tai rojaltin tosiasiallinen edunsaaja tai jonka kiinteän toimipaikan katsotaan olevan kyseisen koron tai rojaltin tosiasiallinen edunsaaja.

\section{$3 c \$$}

Edellä 3 b $\$$ :ssä mainitulla toisesta Euroopan unionin jäsenvaltiosta olevalla yhtiöllä tarkoitetaan eri jäsenvaltioissa sijaitsevien lähiyhtiöiden välisiin korko- ja rojaltimaksuihin sovellettavasta yhteisestä verotusjärjestelmästä annetun neuvoston direktiivin 2003/49/EY, sellaisena kuin se on muutettuna neuvoston direktiivillä 2013/13/EU, liitteessä mainittua yhtiötä, jota koskee, ilman oikeutta verovapauteen, direktiivin 3 artiklan a kohdan iii alakohdassa tarkoitettu vero ja jonka kotipaikka kyseessä olevan jäsenvaltion verolainsäädännön mukaan on tässä jäsenvaltiossa ja jonka verotuksellisen kotipaikan ei katsota tämän jäsenvaltion kolmannen valtion kanssa kaksinkertaisen verotuksen välttämiseksi tekemän sopimuksen mukaan olevan yhteisön ulkopuolella. 


\section{$3 \mathrm{~d} \mathbb{S}$}

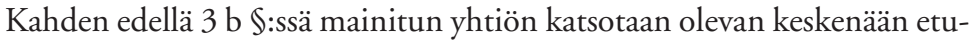
yhteydessä, jos toinen yhtiö omistaa välittömästi vähintään 25 prosenttia toisen yhtiön pääomasta, tai kolmas yhtiö omistaa välittömästi vähintään 25 prosenttia kummankin yhtiön pääomasta.

Omistus voi koskea vain yhtiöitä, joiden kotipaikka on yhteisön alueella.

3 e $\$$

Edellä 3 b §:ssä mainitulla kiinteällä toimipaikalla tarkoitetaan jäsenvaltiossa sijaitsevaa kiinteää liikepaikkaa, josta toisesta jäsenvaltiosta olevan yhtiön liiketoimintaa osaksi tai kokonaan harjoitetaan.

Kiinteää toimipaikkaa pidetään koron tai rojaltin tosiasiallisena edunsaajana:

1) jos se velkasaatava, oikeus tai tiedon käyttö, josta korko- tai rojaltimaksut syntyvät, tosiasiassa liittyy kyseiseen kiinteään toimipaikkaan; ja

2) jos korko- tai rojaltimaksut kiinteälle toimipaikalle ovat 3 c $\$$ :ssä mainitun direktiivin 1 artiklan 5 b kohdassa tarkoitettujen tai mainittujen verojen alaista tuloa siinä jäsenvaltiossa, jossa kiinteä toimipaikka sijaitsee, tai sellaisen veron alaista tuloa, joka on samanlainen tai olennaisesti samanluonteinen ja jota kannetaan tämän direktiivin voimaantulopäivän jälkeen tällä hetkellä suoritettavien verojen lisäksi tai niiden asemesta.

Jos jäsenvaltiosta olevan yhtiön kiinteän toimipaikan katsotaan olevan koron tai rojaltin maksaja tai tosiasiallinen edunsaaja, sellaiseksi ei katsota mitään muuta kyseisen yhtiön osaa $3 \mathrm{~b}$ \$:ää sovellettaessa.

Lain 3 b \$:ää ei sovelleta, jos korot tai rojaltit maksaa jäsenvaltiosta olevan yhtiön kolmannessa valtiossa sijaitseva kiinteä toimipaikka tai ne maksetaan sille ja jos yhtiön liiketoimintaa kokonaan tai osittain harjoitetaan tämän kiinteän toimipaikan kautta.

\section{$3 \mathrm{f} \$$}

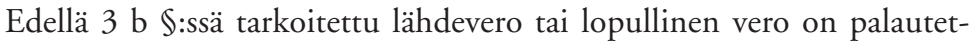
tava vuoden kuluessa sen jälkeen, kun hakemus ja asiaa koskevat kohtuudella vaadittavissa olevat vahvistustiedot on saatu. Jos veroa ei ole palautettu tämän ajan kuluessa, saajayhtiöllä tai kiinteällä toimipaikalla on oikeus saada palautetulle verolle veronkantolain 37 \$:ssä tarkoitetun palautukselle laskettavan koron suuruista hyvityskorkoa. 
$3 \mathrm{~g} \mathbb{S}$

Tuloverolain 9 \$:n 5 momentissa tarkoitettu kommandiittiyhtiö on velvollinen perimään lähdeveroa samassa lainkohdassa tarkoitetun rajoitetusti verovelvollisen osuuteen yhtymän tuloon sisältyvästä 3 §:ssä tarkoitetusta tulosta.

Elokuvarojalteista lähdeverolaissa on erityissäännökset (LähdeVL $13.1 \$$ :n 4 kohta, 13 a $\$, 15 \$$ ja $16 \$$ ). Muista rojalteista poiketen elokuvafilmin käyttämisestä tai käyttöoikeudesta saatu korvaus verotetaan lähdeverotuksen sijaan aina verotusmenettelylain mukaisessa järjestyksessä ja tämä verotus on nettoverotusta, jossa rojaltitulosta ennen verottamista vähennetään sen hankkimismenot. Luonnollisella henkilöllä elokuvarojalteista saatu tulo on siten pääoma- tai ansiotuloa riippuen siitä, miten oikeus siihen on saatu (ks. TVL 52 \$). Yhteisön saama elokuvarojalti verotetaan 20 \%:n yhteisöverokannalla.

\subsubsection{Ulkomaisten taiteilijoiden alhainen lähdevero}

Rajoitetusti verovelvollisen eli ulkomailla asuvan tulon verottamisesta annetussa laissa on erisuuruisia veroprosentteja erilaisille tuloille. Lain 7 \$:n mukaan ulkomailla asuvan vero Suomesta saadusta palkasta, työkorvauksesta ja peitellystä osingosta, kuten myös muusta TVL:n mukaan ansiotulona verotettavasta suorituksesta, on $35 \%$, mutta taiteilijan tai urheilijan toimintaan perustuvasta korvauksesta se on ollut 1990-luvun puolivälistä alkaen vain $15 \%$.

Taiteilijoiden ja urheilijoiden lähdeveron keventämistä perusteltiin hallituksen esityksessä (76/1995) sillä, että verotuksen silloinen, kansainvälisessä vertailussa korkeahko taso vähensi mahdollisuuksia saada Suomeen huippuesiintyjiä. Hallitus ehdotti taiteilijoille ja urheilijoille $30 \%$ :n vähennystä tulosta, jolloin tosiasiallinen vero olisi laskenut $35 \%$ :sta $24,5 \%$ :iin.

Valtiovarainvaliokunta (VaVM 45/1995) pani vielä paremmaksi ja esitti veron alentamista $15 \%$ :ksi, joka myös tuli lakiin. Valiokunta perusteli tätä seuraavasti:

Valiokunta ehdottaa, että hallituksen esitykseen sisältyviä ehdotuksia ulkomaisten taiteilijoiden ja urheilijoiden verotuksen muuttamiseksi 
muutetaan siten, että ne vastaisivat Ruotsin lainsäädäntöä. Suomen lakisystematiikan puitteissa ei kuitenkaan ole mahdollista laatia kaikissa yksityiskohdissaan Ruotsin mallin mukaista lainsäädäntöä. Valiokunta ehdottaa rajoitetusti verovelvollisen tulon ja varallisuuden verottamisesta annetun lain muuttamista koskevaa lakiehdotusta muutettavaksi siten, että se vastaisi Ruotsin järjestelmän periaatteita. Lähdeveroprosentti alenisi 15 prosenttiin, eikä taiteilijan tai urheilijan saamasta tulosta myönnettäisi vähennyksiä.

\subsubsection{Taiteilijat avainhenkilöiden lähdeverolaissa}

Jos ulkomailta Suomeen tulevasta henkilöstä tulee täällä yleisesti verovelvollinen, häntä verotetaan ansiotuloistaan Suomessa progressiivisesti samalla tavalla kuin esimerkiksi täällä asuvia Suomen kansalaisia. Vuodesta 1996 lähtien Suomessa on ollut erityinen lähdeverolaki (15511995), jolla pyritään edistämään erityistä asiantuntemusta omaavien avainhenkilöiden Suomeen tuloa. Tähän päämäärään pyritään tarjoamalla alhaisempi veroaste henkilöille, jotka täyttävät laissa vaaditut edellytykset. Tällaisten henkilöiden palkasta peritään progressiivisen ansiotuloveron sijasta 32 \%:n lopullinen lähdevero. Kyseistä lakia sovelletaan ulkomailta tulevan palkansaajan hakemuksesta.

Lain 2 \$:n mukaan seuraavien vaatimusten tulee täyttyä, jotta henkilö on oikeutettu tähän veroetuun:

1) hän tulee Suomessa yleisesti verovelvolliseksi työskentelyn alkaessa;

2) hänelle tästä työstä maksettava rahapalkka on vähintään 5800 euroa kuukaudessa koko tässä laissa tarkoitetun työskentelyn ajan;

3) hän työskentelee erityisasiantuntemusta edellyttävissä tehtävissä ja

4) hän ei ole Suomen kansalainen eikä hän ole ollut Suomessa yleisesti verovelvollinen tässä laissa tarkoitetun työskentelyn alkamisvuotta edeltäneiden viiden kalenterivuoden aikana.

Jos ulkomailta tuleva palkansaaja toimii opettajana suomalaisessa yliopistossa, korkeakoulussa tai muussa ylemmässä oppilaitoksessa taikka harjoittaa tieteellistä tutkimustyötä yleiseksi eduksi eikä tietyn henkilön tai yhteisön yksityiseksi hyödyksi, 1 momentin 2 ja 3 kohdassa säädettyjä edellytyksiä ei vaadita.

Verovelvollista pidetään ulkomailta tulevana palkansaajana enintään 48 kuukauden ajan tässä laissa tarkoitetun työskentelyn alkamisesta ja niin kauan kuin tämä työskentely on yhtäjaksoista. 
Lakia on sovellettu ulkomailta tulevien johtajien lisäksi mm. urheilijoihin ja valmentajiin. Varmaan sitä voidaan soveltaa myös taiteilijoihin. On kuitenkin huomattava, että kyseistä lakia sovelletaan vain palkkatuloon, ei muuhun ansiotuloon.

\subsection{Taiteen tukijoiden tuloverotus}

\subsubsection{Taidetta tukemaan perustetut yhteisöt}

Vuosina 1865-1885 kannettiin Suomessa valtiolle tulosuostuntaveroa, josta oli vapautettu yleishyödyllisiksi katsottuja yhteisöjä. Esimerkiksi vuonna 1883 säädetystä tulosuostunnasta olivat vapautettuja mm. tieteelliset yhteyskunnat ja stipendirahastot.

Suomen itsenäistyminen ja valtion lisääntynyt varaintarve olivat 1910- ja 1920-lukujen vaihteessa jouduttamassa verolainsäädännön uudistamista. Yleistä pysyvää valtion tuloverotusta odoteltaessa säädettiin itsenäisyyden ensimmäisinä vuosina kutakin vuotta varten lait tulojen suostuntaveroista. Noista veroista olivat vapautettuja mm. kirjallisuuden, tieteen, taiteen tai muun yleishyödyllisen tarkoituksen edistämiseksi perustetut yhteisöt. Vuonna 1920 annetussa tulo- ja omaisuusverolaissa säädettiin verosta vapaiksi mm. tieteen tai taiteen edistämistä varten perustetut tai sellaiset yhteisöt, laitokset ja säätiöt, joiden varat käytettiin yksinomaan yleishyödylliseen tarkoitukseen. Säännös säilyi samanlaisena vuonna 1924 annetussa tulo- ja omaisuusverolaissa ja oli voimassa 1940-luvulle saakka.

Kunnallisverotuksessa ei ennen Suomen itsenäistymistä ollut nimenomaisia säännöksiä yleishyödyllisistä tai aatteellisista yhteisöistä. Kunnallisverosäännöksiä tarkistettiin vuonna 1922 annetuilla laeilla siten, että aatteellinen yhtymä, laitos ja säätiö olivat verovelvollisia ainoastaan kiinteistöstä, elinkeinosta ja liikkeestä saaduista tuloista. Säännökset säilyivät samanlaisina vuonna 1923 annetuissa laeissa, jotka olivat voimassa aina 1950-luvun lopulle saakka.

Vuonna 1943 säädetyssä TOL:ssa yleishyödylliset yhteisöt säilyttivät verotusasemansa eli olivat vapaat tulosta ja omaisuudesta menevästä valtionverosta tulon ja omaisuuden laadusta riippumatta. 
Vuonna 1974 säädettiin tulo- ja varallisuusverolaki. Yleishyödyllisten yhteisöjen esimerkkiluettelossa mainittiin myös sellainen yhteisö, jonka varsinaisena tarkoituksena oli tieteen ja taiteen tukeminen. Asia on samoin myös nykyisen tuloverolain 22 \$:ssä. Yleishyödyllinen yhteisö on TVL 23 \$:n mukaan verovelvollinen saamastaan elinkeinotulosta ja tietyistä kiinteistötuloista. Yleishyödyllisen yhteisön elinkeinotulona ei pidetä mm. yhteisön toimintansa rahoittamiseksi järjestämistä arpajaisista, myyjäisistä, urheilukilpailuista, tanssi- ja muista huvitilaisuuksista, tavarankeräyksestä sekä muusta niihin verrattavasta toiminnasta eikä edellä mainittujen tilaisuuksien yhteydessä harjoitetusta tarjoilu-, myynti- ja muusta sellaisesta toiminnasta saatua tuloa.

Yleishyödyllisten yhteisöjen edullista verotusasemaa on perusteltu erityisesti sillä, että nämä yhteisöt suorittavat tehtäviä, jotka tulevat yhteiskunnan hyödyksi. Kysymys on usein sellaisista tehtävistä, jotka julkisen sektorin olisi otettava itse hoitaakseen, jollei näiden yhteisöjen toimintaa tuettaisi. Veropoliittisesti kysymys onkin siitä, että näiden yhteisöjen toimintamahdollisuuksien turvaamisessa verotuen vaihtoehtona olisi usein yhteiskunnan suora julkinen rahoitus.

Taiteeseen liittyvistä julkaistuista oikeustapauksista mainittakoon seuraavat:

KHO 1982 II 503. Osakeyhtiön, jonka tarkoituksena oli puhenäyttämön ylläpitäminen eräässä kaupungissa, osake-enemmistön omisti sanottu kaupunki. Yhtiön teatteritoiminta rahoitettiin oleelliselta osaltaan, verovuonna lähes 75-prosenttisesti, valtion ja kunnan myöntämin avustuksin. Yhtiö katsottiin yleishyödylliseksi yhteisöksi. Teatteritoimintaa ei katsottu harjoitetun ansiotarkoituksessa eikä sen siten katsottu olevan luonteeltaan liiketoimintaa. Yhtiö ei siis ollut tulostaan verovelvollinen.

KHO 1985 II 506. A:n torvisoittokunta ry:n tarkoituksena oli torvimusiikin edistäminen. Tarkoituksensa toteuttamiseksi yhdistys järjesti konsertteja, harjoituksia sekä koulutus- ja valistustoimintaa torvimusiikin piirissä ja muillakin tavoin pyrki herättämään harrastusta torvimusiikkiin. Se mm. esiintyi erään seurakunnan järjestämissä tilaisuuksissa ja järjesti nuorisotoimintaa. Yhdistys aikoi keväällä 1985 säestää B:n teatterin musiikkinäytelmää, josta se saisi korvauksena 30 esiintymiskerrasta yhteensä 159000 mk. Yhdistyksen jäsenille ei maksettaisi palkkioita. Yhdistykselle suoritettava korvaus oli suunniteltu käytettäväksi 
yhdistyksen toiminnan edelleen kehittämiseksi, soittimien, tarpeiston ja nuottimateriaalin hankkimiseen sekä esiintymis- ja kilpailumatkojen rahoittamiseen. Yhdistystä pidettiin yleishyödyllisenä. Se ei ollut verovelvollinen B:n teatterilta saamastaan korvauksesta.

Suomessa toimii seitsemän yhdistysmuotoista tekijänoikeuden tai lähioikeuksien yhteishallinnointiorganisaatiota. Ne ovat Säveltäjäin tekijänoikeustoimisto Teosto ry, Esittävien taiteilijoiden ja äänitteiden tuottajien tekijänoikeusyhdistys GRAMEX ry, Kopiosto ry, Audiovisual Producers Finland - APFI ry, Visuaalisen alan taiteilijoiden tekijänoikeusyhdistys Kuvasto ry, Sanasto ry sekä Näyttelijöiden tekijänoikeusjärjestö Filmex ry. Tekijänoikeusjärjestöt on rekisteröity aatteellisiksi yhdistyksiksi. Niiden varsinaisena tarkoituksena on taiteen tukeminen ja edunvalvonta. Näin ollen ne täyttävät TVL 22 \$:ssä olevat vaatimukset yleishyödyllisen yhteisöjen statuksen saamiseksi ja ovat tuloverovelvollisia vain elinkeinotulosta. TVL 23 \$:ssä on luettelo sellaisista tuloista, joita ei katsota elinkeinotuloiksi. Verotuskäytännössä on vakiintuneesti katsottu, ettei yleishyödyllisten yhteisöjen tekijänoikeuksien hallinnoinnista saama tulo ole tuloverotuksessa veronalaista elinkeinotuloa (ks. HE 159/2008). ${ }^{148}$

Yleisradio Oy:stä on oma lakinsa (1380/1993). Yhtiön osakekanta on lähes kokonaan valtion omistuksessa ja hallinnassa. Yhtiön tehtävänä on tuoda monipuolinen ja kattava julkisen palvelun televisio- ja radio-ohjelmisto jokaisen saataville yhtäläisin ehdoin. Julkisen palvelun ohjelmatoiminnan tulee mm. tuottaa, luoda, kehittää ja säilyttää kotimaista kulttuuria, taidetta ja virikkeellistä viihdettä. Yleisradio Oy:n toiminta rahoitetaan nykyisin pääosin yleisradioverolla, joka on lähinnä tuloveron luonteinen. Yleisradio Oy on kokonaan vapautettu maksamasta veroa tulon perusteella (TVL $20 \$$ ).

Veikkaus $O y$ on suomalainen rahapeliyhtiö, jolla on erittäin suuri merkitys mm. taiteen rahoittajana. Veikkaus Oy on verovelvollinen vain muusta kuin arpajaislain mukaisen yksinoikeuden nojalla harjoittamastaan rahapelitoiminnasta saamastaan tulosta (TVL 21 c $\$$ ).

148 Arvonlisäverotuksesta ks. jäljempänä luku 6.3.1. 


\subsubsection{Taidemenot yritysten luonnollisina vähennyksinä}

\subsubsection{Vaihto-omaisuus}

Vaihto-omaisuutta ovat EVL 10 \$:n mukaan elinkeinotoiminnassa sellaisinaan tai jalostettuina luovutettaviksi tarkoitetut kauppatavarat, raaka-aineet, puolivalmisteet ja muut hyödykkeet sekä elinkeinotoiminnassa kulutettaviksi tarkoitetut poltto- ja voiteluaineet ja muut tarvikkeet. Vaihto-omaisuuden hankintameno on EVL 28 \$:n mukaan sen verovuoden kulua, jona vaihto-omaisuus on luovutettu, kulutettu tai menetetty. Verovelvollisella verovuoden päättyessä olevan vaihto-omaisuuden hankintamenosta on verovuoden kulua kuitenkin se osa, joka ylittää vastaavan vaihto-omaisuuden hankintaan verovuoden päättyessä todennäköisesti tarvittavan hankintamenon tai siitä samana ajankohtana todennäköisesti saatavan luovutushinnan.

\subsubsection{Käyttöomaisuus}

\subsection{Irtain kuluva käyttöomaisuus}

Käyttöomaisuutta ovat EVL 12 \$:n mukaan elinkeinotoiminnassa pysyvään käyttöön tarkoitetut esineet ja erikseen luovutettavissa olevat aineettomat oikeudet. Koneiden, kaluston ja muun niihin verrattavan irtaimen käyttöomaisuuden hankintamenoista tehdään poistot yleensä yhtenä eränä menojäännöksestä, ja poiston suuruus on tavallisesti enintään $25 \%$. Verovelvollisen vaatiessa irtaimen omaisuuden hankintameno poistetaan kokonaan sinä vuonna, jona omaisuus on otettu käyttöön, jos käyttöomaisuuden taloudellinen käyttöaika on enintään 3 vuotta taikka jos hankintameno on enintään 850 euroa (EVL $33 \$$ ).

Patentin ja muun voimassaoloajaltaan rajoitetun erikseen luovutettavissa olevan aineettoman oikeuden sekä sellaisen erikseen luovutettavissa olevan aineettoman oikeuden, jonka voimassaoloaikaa ei ole rajoitettu, hankintameno poistetaan EVL 37 \$:n mukaan yhtä suurin vuotuisin poistoin 10 vuodessa tai verovelvollisen todennäköiseksi osoittamana sitä lyhyempänä kyseisen oikeuden taloudellisena käyttöaikana. 


\subsection{Taide-esineet kulumattomana käyttöomaisuutena}

Maa-alue, arvopaperit ja muut sellaiset hyödykkeet ovat EVL 12 \$:n mukaan kulumatonta käyttöomaisuutta. Kulumatonta käyttöomaisuutta voivat olla esimerkiksi yrityksen tiloihin hankitut arvokkaat taulut ja veistokset. Jos taide-esine on hankittu yrityksen edustustiloihin, vähennyskelpoisuutta rajoittanee EVL $8 \$$, jonka mukaan edustusmenoista vain $50 \%$ on vähennyskelpoista.

Kulumattoman käyttöomaisuuden hankintamenon vähentämisestä säädetään EVL 42 §:ssä. Jos verovelvollinen osoittaa, että muun kulumattoman käyttöomaisuuden kuin maa-alueen käypä arvo on verovuoden päättyessä sen hankintamenoa olennaisesti alempi, hankintamenosta saa tehdä sellaisen poiston, joka alentaa hankintamenon määrän käyvän arvon suuruiseksi. Kulumattoman käyttöomaisuuden veronalaiset luovutushinnat ja muut vastikkeet tuloutetaan ja vähentämättä oleva hankintameno poistetaan yleensä sinä verovuonna, jona käyttöomaisuus on luovutettu, tuhoutunut tai vahingoittunut.

\subsection{Taide rakennuksen osana}

Rakennuksen ja rakennelman hankintameno vähennetään poistamatta olevan hankintamenon osan perusteella määritettävin poistoin (EVL 34 \$). Laissa säädetyt maksimipoistoprosentit ovat pienemmät kuin irtaimen käyttöomaisuuden kohdalla. Niiden suuruus riippuu rakennuksen käyttötarkoituksesta ja rakennusmateriaalistakin. Jos taide on rakennuksen erottamaton osa (esim. taiteellinen seinä), sen hankintamenoa ei voitane erottaa rakennuksesta erilliseksi poistokohteeksi eikä katsoa kulumattomaksi käyttöomaisuudeksi.

\subsubsection{Suhdetoiminta- yms. menot}

Yritys voi antaa työntekijöilleen tavanomaisia henkilökuntaetuja, esimerkiksi kulttuuriseteleitä. Vaikka tällaiset edut olisivat työntekijöille verovapaita (ks. TVL 69 \$), niiden hankintameno on yritykselle vähennyskelpoinen.

Arvoltaan vähäiset raha- tai esinelahjoitukset yleishyödylliseen ja samalla paikalliseen tai yrityksen toimialaa lähellä olevaan tarkoitukseen voidaan Verohallinnon ohjeiden mukaan katsoa suhdetoiminnan luonteisiksi menoiksi, jotka ovat vähennyskelpoisia verotuksessa. 
Tällaisia lahjoituksia yritys saa ohjeiden mukaan vähentää enintään $850 €$ lahjoituksensaajaa kohti. Seuraavassa käsitellään sellaisia vähennyskelpoisia lahjoituksia, jotka eivät ole luonnollisia vähennyksiä.

\subsubsection{Yhteisön lahjoitusvähennys}

Lahjoitusvähennys tuli verojärjestelmäämme 1930-luvun lopulla, kun sodan vaara kasvoi. Vuonna 1938 Suomessa säädettiin valtionverotuksessa vähennyskelpoiseksi rahamäärä, jonka verovelvollinen luovutti valtiolle käytettäväksi valtiovarainministeriön hyväksymään tarkoitukseen. Hallitus viittasi esityksessään siihen, että eräät teollisuudenharjoittajat ilmoittivat halunsa tehdä huomattavia lahjoituksia valtiolle ilmatorjunnan ja kaasusuojelun järjestämiseksi teollisuusalueillaan yhteistoiminnassa puolustuslaitoksen kanssa, joka puolestaan piti tällaista järjestelyä erittäin suotavana.

Vuonna 1943 säädetyn tulo- ja omaisuusverolain mukaan vähennyskelpoisia olivat lahjoitukset yhteishyödylliseen tarkoitukseen sen mukaan kuin asetuksella säädettiin. Tammikuun 1944 alussa annetun tulo- ja omaisuusveroasetuksen mukaan vähennyskelpoisia olivat ne lahjoitukset, jotka annettiin valtiolle maanpuolustusta edistävään tarkoitukseen. Lisäksi säädettiin valtiovarainministeriön harkinnasta riippuva vähennyskelpoisuus lahjoituksille, jotka annettiin sodasta kärsimään joutuneitten avustamiseksi.

Kohta sodan jälkeen vuonna 1945 muutettiin tulo- ja omaisuusveroasetuksen vähennyskelpoisia lahjoituksia koskevia säännöksiä paremmin rauhanajan olosuhteita vastaaviksi. Nyt säädettiin valtiovarainministeriön harkinnasta riippuva vähennyskelpoisuus myös sellaisille lahjoituksille, jotka annettiin käytettäväksi kotimaista elinkeinoelämää tai ruumiinkulttuuria edistävään tai tieteelliseen tarkoitukseen. 1950-luvun alussa taide lisättiin niihin tarkoitusperiin, joita edistäville lahjoituksille voitiin saada vähennysoikeus.

Lahjoitusvähennyksen ala oli laajimmillaan vuonna 1986 säädetyn lainmuutoksen jälkeen. Yhteisöjen lahjoitusvähennystä koskeva silloisen tulo- ja varallisuusverolain 33 a. $3 \$$ mahdollisti tietynsuuruiset rahalahjoitukset myös tiedettä tai taidetta edistävään tarkoitukseen Suomen valtiolle, suomalaiselle yliopistolle tai korkeakoululle taikka verohallituksen nimeämälle suomalaiselle yhdistykselle, laitokselle tai 
säätiölle, jonka varsinaisena tarkoituksena oli tieteen tai taiteen tukeminen.

Kokonaisverouudistuksen yhteydessä 1980-luvun lopulla vähennyskelpoisten lahjoitusten piiriä supistettiin poistamalla siitä maanpuolustus, kehitysyhteistyö ja humanitaarinen avustustoiminta. Muun muassa taide sen sijaan jäi vähennykseen oikeuttavien kohteiden piiriin. Nykyisin yhteisön lahjoitusvähennystä koskeva TVL $57.1 §$ kuuluu seuraavasti:

Yhteisö saa valtioneuvoston asetuksella tarkemmin säädettävällä tavalla vähentää tulostaan:

1) vähintään 850 euron ja enintään 250000 euron suuruisen rahalahjoituksen, joka on tehty tiedettä, taidetta tai suomalaisen kulttuuriperinteen säilyttämistä edistävään tarkoitukseen Euroopan talousalueeseen kuuluvalle valtiolle tai Euroopan talousalueella olevalle julkista rahoitusta saavalle yliopistolle tai korkeakoululle taikka näiden yhteydessä olevalle yliopistorahastolle;

2) vähintään 850 euron ja enintään 50000 euron suuruisen rahalahjoituksen, joka on tehty tiedettä, taidetta tai suomalaisen kulttuuriperinteen säilyttämistä edistävään tarkoitukseen sellaiselle Verohallinnon nimeämälle Euroopan talousalueella olevalle yhdistykselle, säätiölle tai jonkin edellä mainitun yhteydessä olevalle rahastolle, jonka varsinaisena tarkoituksena on tieteen tai taiteen tukeminen taikka suomalaisen kulttuuriperinteen säilyttäminen.

\subsubsection{Luonnollisen henkilön lahjoitusvähennys}

Oikeus lahjoitusvähennykseen oli pitkään vain yhteisöillä, ei luonnollisilla henkilöillä. Luonnolliset henkilöt saivat oikeuden lahjoitusvähennykseen vasta vuonna 1986 tehdyllä lainmuutoksella, jolla silloiseen tulo- ja varallisuusverolakiin lisättiin 33 a $\$$. Tuo pykälä mahdollisti luonnollisille henkilöille vähennyksen tietynsuuruisista rahalahjoituksista, jotka tehtiin käytettäväksi maanpuolustukseen, kehitysyhteistyöhön tai humanitaariseen avustustoimintaan. Luonnollisen henkilön lahjoitusvähennyksen piiriin eivät tulleet lahjoitukset taidetta varten.

Kokonaisverouudistuksen yhteydessä 1980-luvun lopussa vähennyskelpoisten vähennysten piiriä supistettiin poistamalla vähennyksen piiristä edellä mainitut maanpuolustus, kehitysyhteistyö ja 
humanitaarinen avustustoiminta, ja vähennysoikeus säilyi vain yhteisöillä.

Luonnolliset henkilöt saivat lahjoitusvähennysoikeuden jälleen vuoden 2009 alusta, kun TVL:iin lisättiin 98 a \$. Se kuuluu vuonna 2015 säädetyn lainmuutoksen jälkeen seuraavasti:

Luonnollinen henkilö ja kuolinpesä saa vähentää puhtaasta ansiotulostaan vähintään 850 euron ja enintään 500000 euron suuruisen rahalahjoituksen, joka on tehty tiedettä tai taidetta edistävään tarkoitukseen Euroopan talousalueella olevalle julkista rahoitusta saavalle yliopistolle tai korkeakoululle taikka näiden yhteydessä olevalle yliopistorahastolle.

Tämä vähennys koskee siis myös taidetta varten tehtyjä lahjoituksia yliopistoille ja yliopistorahastoille. 


\section{Perintö- ja lahjaverotus ${ }^{149}$}

\subsection{Perintö- ja lahjaveron historiasta}

Roomassa perintövero otettiin käyttöön keisari Augustuksen aikana (31 eaa.-14 jaa.). Perintövero oli silloin $5 \%$ perintöosuuden arvosta, ja siitä oli vapautettu lähiomaisten saamat perinnöt ja pienet perinnöt. Veroa arvosteltiin ankarasti ja kapinallakin uhattiin, mutta vero tuli hyväksytyksi, kun vaihtoehtona olisi ollut vieläkin vastenmielisempi, provinsseissa jo kannettu maavero.

Keskiajalla kannetun pääkymmenyksen eli pääomakymmenyksen voitiin katsoa sisältävän tietynlaisen ajatuksen perinnön verottamisesta. Tuolla kymmenyksellä tarkoitettiin kirkon vaatimusta, että jokaisen hyvän kristityn tuli ainakin kerran elämänsä aikana suorittaa kymmenesosa varallisuudestaan kirkolle.

Ruotsissa alkoi varsinainen perinnön verotusta koskeva lainsäädäntö kehittyä pääasiassa leimaverosäännösten pohjalta. Myös suostuntaveroasetuksissa oli säännöksiä perinnön ja testamentin verottamisesta. Ensimmäinen tällainen säännös annettiin vuonna 1789 .

Vuosina 1810-1917 voimassa olleissa leimaveroasetuksissa säädettiin perukirjasta edelleenkin otettavaksi leimaveroa pesän säästön perusteella. Testamentilla saadusta omaisuudesta perittiin leimaveroa testamenttia valvottaessa.

Vuoden 1918 Suomen valtiopäiville annetun hallituksen esityksen mukaisesti säädettiin laki perintö- ja lahjaverosta, joka oli voimassa vuoden 1921 loppuun. Tällä lailla kumottiin aikaisemmat säännökset,

149 Perintö- ja lahjaverotuksesta tarkemmin esim. Puronen Lahjaverotuksen ala (1990), Puronen Perintö- ja lahjaverotus (2015) ja Linnakangas Kansanvalta, ikä, vero-oikeus (2020) s. 53 ss. 
jotka koskivat perukirjojen, testamenttien ja lahjakirjojen varustamista leimamerkeillä, sekä kuolinpesäkalustoprosenttia eli oikeusviraston prosenttia koskevat säännökset. Lain mukaan perintövero oli suoritettava perinnön- tai testamentinsaajalle tulevasta osuudesta (perintöosuusvero) eikä siis koko pesään kohdistuvana jäämistöverona. Veron määrämisen toimittivat maalla kruununvoudit ja kaupungeissa maistraatit. Seuraava perintö- ja lahjaverolakimme tuli voimaan jo 1.1.1922. Perintöveron määrääminen toimitettiin perintöosuusverona perukirjan taikka poikkeustapauksessa perinnönjakokirjan tai veroilmoituksen perusteella.

Osittain vieläkin voimassa oleva perintö- ja lahjaverolaki säädettiin vuonna 1940. Sitä muutettiin vuonna 1995 niin, että I veroluokkaan kuului myös sellainen avopuoliso, johon tuloverotuksessa sovellettiin puolisosäännöstä. Luovuttiin myös kunnallisverottamasta sivuperintöjä ja -lahjoja; niitä oli siihen saakka kohdeltu ansiotuloina. Laki muutettiin vuoden 2007 lopulla niin, että III veroluokasta luovuttiin ja siihen kuuluneet sijoitettiin II veroluokkaan, johon tämän jälkeen kuuluivat myös muut sukulaiset ja vieraat. Samaa sukupuolta olevat rekisteröidyssä parisuhteessa olevat on 2000-luvun alusta lukien rinnastettu puolisoihin, ja he kuuluvat siten I veroluokkaan. Monessa maassa on perintöverosta luovuttu, ja meilläkin aiheesta keskustellaan jatkuvasti.

\subsection{Taidesäätiöiden ja -yhdistysten asema}

Vuonna 1921 säädetyn perintö- ja lahjaverolain 2 \$:ssä säädettiin seuraavasti:

"Tässä laissa määrättyä veroa ei kanneta kruununperinnöstä ${ }^{150}$ eikä sellaisesta omaisuudesta, joka testamentilla tai lahjana on annettu valtiolle tai sen laitokselle, maakunnalle, kunnalle, seurakunnalle, uskonnolliselle yhdyskunnalle, armeliaisuus- tai opetuslaitokselle taikka kansanvalistusta varten tahi tieteelliseen, taiteelliseen tai muuhun kotimaiseen yleishyödylliseen tarkoitukseen käytettäväksi."

150 Kruununperintö on perintö, joka perijöiden puuttumisen vuoksi menee valtiolle. 
Vuonna 1940 säädetyn perintö- ja lahjaverolain 2 \$:ssä säännös sai seuraavan muodon, jossa se on yhä voimassa:

"Tässä laissa säädettyä veroa ei suoriteta kruununperinnöstä eikä sellaisesta omaisuudesta, joka yhdistyksen sääntöjen mukaan sen toiminnan lakattua on siirtynyt toiselle, taikka joka testamentilla tai lahjana on annettu valtiolle tai sen laitokselle, maakunnalle, kunnalle, kuntayhtymälle, seurakunnalle tai muulle uskonnolliselle yhdyskunnalle sekä armeliaisuus- tai opetuslaitokselle. Sama olkoon voimassa myös omaisuudesta, joka on annettu aatteelliselle yhdistykselle tai muulle yhteisölle, laitokselle tai säätiölle, jolla, sen tarkoittamatta toiminnallaan tuottaa siihen osallisille taloudellisia etuja, on tieteellinen, taiteellinen, kansanvalistusta, maanpuolustusta tai kotimaista elinkeinoelämää edistävä tahi muu yleishyödyllinen tarkoitus.”

Yhdessä vaiheessa yleishyödyllisen yhteisöjen määritelmä perintö- ja lahjaverolaissa oli aivan samanlainen kuin tulo- ja omaisuusverolaissa, ja määritelmät ovat yhä niin lähellä toisiaan, että asiallista eroa ei ainakaan taiteen osalta juuri ole.

\subsection{Taideteokset tavanomaisena koti- irtaimistona}

Perintö- ja lahjaverolain 7 b $\$: n$ mukaan perintöveroa ei ole suoritettava perinnönjättäjän omassa tai hänen perheensä käytössä olleesta tavanomaisesta koti-irtaimistosta siltä osin kuin sen arvo on enintään 4000 euroa.

Tavanomaisen koti-irtaimiston käsitteellä on merkitystä myös luovutusvoittoverotuksessa, koska omassa tai perheen käytössä olleen tavanomaisen koti-irtaimiston luovutuksista saadut voitot ovat verovapaita siltä osin kuin ne ovat verovuonna yhteensä enintään 5000 euroa (TVL 48.1 \$:n 2 kohta). Tuloverolaissakaan ei ole tarkemmin määritelty, mitä tavanomaisella koti-irtaimistolla tarkoitetaan, eikä asiasta ole myöskään julkaistua oikeuskäytäntöä. Tavanomaisena koti-irtaimistona voidaan Verohallinnon tulovero-ohjeen mukaan pitää mm. astiastoja, vaatteita, kodinkoneita, huonekaluja, harrastusvälineitä, työkaluja ja kirjoja. Koti-irtaimiston luovutusvoittojen 
verovapautta koskevaa säännöstä ei Verohallinnon ohjeen mukaan sovelleta tavanomaista arvokkaampien taulujen ja muiden taideesineiden taikka sijoituskohteina pidettävien esineiden luovutuksiin.

Vielä 2 500-3 000 euron arvoinen taulu voitaneen yleensä katsoa perintöverotuksessa tavanomaiseksi koti-irtaimistoksi. ${ }^{151}$ Koska asuntoirtaimisto lähes poikkeuksetta arvostetaan perukirjassa hyvin varovasti, säännöksellä on käytännön merkitystä hyvin harvalle.

\subsection{Tekijänoikeudet oikeuskäytännössä}

Laeissamme ei ole eikä ole koskaan ollut nimenomaisia säännöksiä tekijänoikeuksien asemasta perintö- ja lahjaverolaissa, mutta asiasta on erittäin tärkeitä oikeustapauksia. Ensimmäinen ennakkopäätös oli täysistunnossa äänestyksen (16-9) jälkeen tehty KHO 1960 I 13. Siinä katsottiin, että perillisille siirtynyttä oikeutta vainajan sävellysteoksiin ei pidetty sellaisena omaisuutena, josta PerVL 1 \$:n nojalla oli suoritettava perintöveroa.

KHO:n linjauksen oikeellisuutta epäiltiin. Asia tuli uudelleen ratkaistavaksi 2000-luvun alussa. Tällä kertaa kysymys oli kirjailijan perillisistä. Päätöksessä KHO 2004:55 aikaisempi kanta säilyi, kun jaostoplenumissa äänestyksen 7-1 jälkeen katsottiin, että perillisille siirtynyt oikeus perittävän kirjallisiin teoksiin ei ollut sellaista omaisuutta, josta PerVL 1 \$:n nojalla oli suoritettava perintöveroa. KHO hyväksyi verovelvollisten valituksen ja kumosi toisella kannalla olleen hallinto-oikeuden ratkaisun. KHO perusteli päätöstään seuraavasti:

Tekijänoikeuslain 1 §:n 1 momentin mukaan sillä, joka on luonut kirjallisen tai taiteellisen teoksen, on tekijänoikeus teokseen. Tekijänoikeuslain $2.1 \$$ :n mukaan tekijänoikeus tuottaa laissa säädetyin rajoituksin yksinomaisen oikeuden määrätä teoksesta valmistamalla siitä kappaleita ja saattamalla se yleisön saataviin. Kustannussopimuksella tekijä luovuttaa tekijänoikeuslain 31.1 \$:n mukaan kustantajalle oikeuden painamalla tai sen kaltaista menetelmää käyttäen monistaa ja julkaista kirjallisen tai taiteellisen teoksen. Tekijänoikeus on aineeton oikeus, ja se voidaan laissa

151 Puronen Perintö- ja lahjaverotus (2015) s. 207. 
säädetyin rajoituksin luovuttaa kokonaan tai osittain. Oikeus tuottaa tekijälleen sekä taloudellisia että hänen henkilöönsä liittyviä oikeuksia.

Tekijänoikeuslain 41.1 \$:n mukaan tekijän kuoltua sovelletaan tekijänoikeuteen avio-oikeutta, perintöä ja testamenttia koskevia sääntöjä. Lain 42 \$:n mukaan tekijänoikeutta ei saa ulosmitata tekijältä itseltään eikä siltä, jolle se on siirtynyt avio-oikeuden, perinnön tai testamentin nojalla. Tekijän oikeudenomistajat saavat siten hyväkseen tekijänoikeuslain tekijälle kuuluvan oikeussuojan.

PerVL 1.1 \$:n mukaan on se, joka perintönä, testamentilla tai lahjana saa omaisuutta, velvollinen suorittamaan siitä valtiolle veroa sen mukaa kuin tässä laissa säädetään. Lain 1.2 \$:ssä ja 2 §:ssä tarkennetaan lain soveltamisalaa, mutta 1.1 \$:ssä ei tarkemmin määritellä veron kohteena olevaa omaisuutta, eikä muuallakaan PerVL:ssa ole nimenomaan tekijänoikeuksia koskevaa säännöstä.

Varallisuusverolain (1537/1992) 9.2 \$:n 3 kohdan mukaan veronalaisia varoja ovat erikseen luovutettavissa olevat vastiketta vastaan hankitut aineettomat oikeudet, kuten patenttioikeus sekä oikeus kirjalliseen tai taiteelliseen teokseen, valokuvaan ja tavaramerkkiin. Perintönä saatu tekijänoikeus on siis varallisuusverosta vapaa.

KHO on antanut päätöksen 1960 I 13, jonka mukaan perillisille siirtynyttä oikeutta vainajan sävellysteoksiin ei pidetty sellaisena omaisuutena, josta PerVL 1 \:n nojalla oli suoritettava perintöveroa. Tuolloin oli voimassa tulo- ja omaisuusverolaki (888/1943), jonka 32 \$:n mukaan muun ohella kustannusoikeus luettiin varoiksi. Lainkohdan perusteella pyrittiin kuitenkin verottamaan ainoastaan elinkeinotoiminnassa käytettyjä aineettomia oikeuksia. Säännöstä tulkittiin suppeasti, eikä kustannusoikeutta verotettu alkuperäisen omistajan kädessä.

Tulo- ja omaisuusverolain 32 \$:ää muutettiin 29.12.1967 annetulla lailla (613/1967), jota sovellettiin ensi kerran vuodelta 1968 toimitettavassa verotuksessa. Tuolla lainmuutoksella tulo- ja omaisuusverolain 32 \$:n 3 kohta sai varallisuusverolain 9.2 \$:n 3 kohtaa vastaavan sanamuodon. Verolakivaliokunta katsoi tuolloin hallituksen esityksen (HE 100/1967 vp) johdosta antamassaan mietinnössä (Verolakivaliokunnan mietintö No 2) kohtuulliseksi ehdottaa, että veronalaisiksi varoiksi luetaan oikeudet, jotka on hankittu vastiketta vastaan. Omaisuusverotuksen ulkopuolelle jäisi mietinnön mukaan mm. kustannusoikeus taiteilijan kädessä. Verolakivaliokunnan mukaan tällöin vältytään niistä suurista arvostamisvaikeuksista, joita ilmeisesti syntyisi, jos veronalaisiin varoihin luettaisiin muutkin kuin vastiketta vastaan hankitut aineettomat oikeudet.

Oikeus- ja verotuskäytäntö tekijänoikeuksien perintöverotuksen suhteen on vakiintunut KHO:n em. päätöksen jälkeen samanlaiseksi kuin vastikkeetta hankittujen tekijänoikeuksien verotus varallisuusverotuksessa, eli ne ovat jääneet kummankin verotuksen ulkopuolelle. Tähän pitkäaikaiseen ja vakiintuneeseen käytäntöön ei ole katsottu tarpeelliseksi 
puuttua lainsäädäntöteitse. Kun lisäksi otetaan huomioon tekijänoikeuden erityinen luonne ja tekijänoikeuden arvostamiseen liittyvät vaikeudet, KHO katsoi äänestyksen jälkeen, ettei perillisille siirtynyttä oikeutta kirjailijan teoksiin voida pitää sellaisena omaisuutena, josta on PerVL 1 \$:n nojalla suoritettava perintöveroa. ${ }^{152}$

Myöhemmässä päätöksessä KHO 2016:5 lahjana siirtyvää tavaramerkkioikeutta pidettiin sellaisena omaisuutena, josta oli PerVL 1 \$:n nojalla suoritettava lahjaveroa. Koska asiassa viitattiin myös tekijänoikeuksia koskeviin KHO:n ratkaisuihin, päätöksen perusteluja on syytä selostaa tarkemmin:

KHO totesi, että PerVL:ssa ei ole nimenomaan tavaramerkkejä koskevaa säännöstä. Tavaramerkkilain 1.1 \$:n mukaan rekisteröinnillä saadaan yksinoikeus tavaramerkkiin erityiseksi tunnusmerkiksi myytäviksi tarjottavien tai muutoin elinkeinotoiminnassa liikkeeseen laskettavien tavaroiden erottamiseksi toisten tavaroista. Lain 2.1 \$:n mukaan yksinoikeus tavaramerkkiin voidaan saada ilman rekisteröintiäkin, kun merkki on tullut vakiintuneeksi. Tavaramerkkilain 32.1 \$:n mukaan tavaramerkki voidaan luovuttaa toiselle.

A aikoi lahjoittaa pojalleen B:lle omistamansa C Oy:n koko osakekannan ja henkilökohtaisesti omistamansa, yhtiön liiketoiminnassa käytettävät tavaramerkkioikeudet. C Oy oli maksanut luovutuksen kohteena olevista tavaramerkeistä A:lle rojaltikorvauksia 108000 euroa vuodessa ainakin vuosilta 2010-2012. Tavaramerkkioikeuksien osalta A:n oli tarkoitus pidättää itselleen elinikäinen tuotto-oikeus.

Asiassa oli KHO:ssa kysymys siitä, ovatko tavaramerkkioikeudet sellaista omaisuutta, josta on PerVL 1 §:n nojalla suoritettava lahjaveroa. PerVL:ssa ei ole säädetty aineettoman omaisuuden jäämisestä lain

152 Eri mieltä ollut jäsen totesi mm., että KHO oli täysistuntoratkaisussaan 1960 I 13 katsonut, että perillisille siirtynyttä oikeutta vainajan sävellysteoksiin ei ollut pidettävä sellaisena omaisuutena, josta PerVL $1 \$$ :n nojalla oli suoritettava perintöveroa. Verotuskäytännössä näyttäisi sen jälkeen noudatetun tuota KHO:n enemmälti perustelematta jäänyttä laintulkintaa. Asia oli otettu käsiteltäväksi KHO:n veroasioita käsittelevän jaoston täydessä kokoonpanossa. Eri mieltä ollut jäsen katsoi, että kysymys PerVL:n oikeasta sisällöstä oli tässä tilanteessa ratkaistavissa KHO:n em. ratkaisun estämättä. Hän päätyi siihen, että PerVL:n sanamuodon ja tavanmukaisen laintulkinnan pohjalta oli perintönä saaduista tekijänoikeuksista suoritettava perintöveroa. Hän ei katsonut laintulkinnan muuttamisen loukkaavan verovelvollisten yhdenvertaisuutta, eikä asiassa ollut kysymys luottamuksensuojasta. Myöskään tekijänoikeuksien arvostamisessa mahdollisesti ilmenevillä vaikeuksilla ei hänen mukaansa ollut tässä merkitystä. 
soveltamisalan ulkopuolelle. Näin ollen myös aineettoman omaisuuden on lähtökohtaisesti katsottava olevan PerVL 1 \$:ssä tarkoitettua omaisuutta, kun se voi olla luovutuksen kohteena. Yritystoiminnassa käytettävät tavaramerkit eivät luonteeltaan vastaa tekijänoikeuksia, joiden saannoista on ollut kysymys ratkaisuissa KHO 1960 I 13 ja KHO 2004:55. Aineetonta omaisuutta ei myöskään voida jättää perintö- ja lahjaverotuksen ulkopuolelle vain sen arvostamiseen liittyvien vaikeuksien vuoksi.

KHO katsoi, että lahjoitettavat tavaramerkkioikeudet ovat sellaista omaisuutta, josta on PerVL 1 §:n nojalla suoritettava lahjaveroa. Ennakkoratkaisussa tuli määrittää tavaramerkeille käypä arvo ja käsitellä myös muilta osin tavaramerkkien luovutuksiin liittyvät ennakkoratkaisuhakemuksessa esitetyt kysymykset.

KHO:n mukaan yritystoiminnassa käytettävät tavaramerkit eivät siis luonteeltaan vastaa tekijänoikeuksia, joiden saannoista oli aikaisemmissa KHO:n ratkaisuissa ollut kysymys. Näin ollen tekijänoikeuksia koskevaa linjausta ei ole muutettu. 


\section{Huvi- ja elokuvaverotus}

\subsection{Huvien verotus ennen Suomen itsenäistymistä}

Huvitilaisuuksista kannettiin meillä veroa jo 1700-luvun lopulla. Erilaisten artistien (comodianter och marionettspelare, lindansarne och dylika) oli nimittäin 12.12.1782 annetun julistuksen mukaan suoritettava jokaisesta esiintymiskerrasta maksu Kehruuhuonerahastoon. ${ }^{153}$ Huveja verotettiin myös vaivais- ja työhuonerahaston hyväksi 5.5.1818 annetun julistuksen perusteella (för skådespel, concerter, assemleer). Kehruuhuone on vanha nimitys naisten työvankiloille, joissa vangeilla teetettiin lähinnä käsitöitä, kuten kehruuta.

Joulukuussa 1914 keisarin armollisessa asetuksessa säädettiin pääsymaksuista kannettavaksi meneillään olleen sodan aikana erityinen valtiolle menevä vero. Tämä huvivero ymmärrettiin aluksi lähinnä ylellisyysveroksi. Tästä verosta olivat vapaita ne tilaisuudet, joiden puhdas tuotto meni kokonaan sellaisille yhdistyksille ja laitoksille, joiden tarkoituksena oli haavoittuneiden ja sairaiden sotilaiden hoitaminen taikka huolenpito sotaan kutsuttujen perheistä. Vero oli aluksi $10 \%$ pääsylipun hinnasta, mutta se korotettiin $20 \%$ :ksi vuonna 1916. Vero kannettiin siten, että pääsylippuun kiinnitettiin veron määrää vastaavat postimerkit. Merkit oli kiinnitettävä lippuihin niin, että merkkien yläosa jäi kävijälle annettavaan pääsylippuun ja alaosa lippuvihon kannassa olevaan lipun osaan.

153 Huvi- ja elokuvaverotuksesta ks. esim. Linnakangas Elokuvaverotus (1990). 


\subsection{Itsenäistymisestä 1960-luvun alkuun}

Suomen itsenäistyminen ja sotatilan päättyminen eivät merkinneet huviverotuksen loppumista. Vuonna 1920 siirryttiin käyttämään leimamerkkejä ja vuonna 1922 valtion toimesta painettuja pääsylippuja. Tansseista samoin kuin sirkusnäytännöistä oli 1920-luvulla yleensä suoritettava huviveroa $40 \%$ pääsylipun hinnasta. Veroa ei suoritettu tilaisuuksista, joiden pääasiallisena ohjelmana oli puheita, esitelmiä, lausuntaa, laulu- ja soittoesityksiä, näytelmiä yms. mutta joissa tanssia ohjelman päätyttyä oli enintään yhden tunnin ajan. Sodan jälkeen vuonna 1946 tanssien huvivero nostettiin jopa $50 \%$ :iin. Vuonna 1948 säädettiin sellainen helpotus, että verovapaassa tilaisuudessa sai tanssia 1,5 tuntia. Tanssien huvivero alennettiin 1950-luvun lopulla 25-30\%:iin.

Huviverotus koski myös elokuvia. Ensimmäiset elokuvaesitykset Suomessa oli järjestetty jo 1890-luvulla, ja aluksi se tapahtui ulkomaalaisten yrittäjien sirkus- ja muiden viihdekiertueiden yhteydessä. Vuoden 1921 alussa voimaan tulleessa leimaverolaissa veroksi säädettiin enintään 50 pennin hintaisesta lipusta 10 penniä ja sitä kalliimmasta lipusta "kinematografinäytännöissä" 40 penniä markalta tai sen osalta. Nyt elokuvasta oli ensi kerran oma erityismaininta huviverosäännöksissä. Elokuvanäytäntöjen huviverotuksessa otettiin vuoden 1921 lopulta asti huomioon ohjelmiston laatu. Normaali vero oli $30 \%$, mutta tiede- ja taide-elokuvilla vero oli $20 \%$. Vuoden 1927 alusta tiede- ja opetuselokuvat säädettiin verottomiksi. Taidefilmien veroksi tuli $15 \%$ ja muiden $30 \%$.

Kotimainen elokuva tuli verovapaaksi vuonna 1930. Hyvin tärkeä oli myös vuonna 1933 voimaan tullut säännös, jonka mukaan sellaisten elokuvien veroa alennettiin, joiden täytekuvana esitettiin vähintään 200 metrin pituinen Suomessa valmistettu elokuva, joka oli katsottava tiede-, opetus- tai taide-elokuvaksi taikka joka kuvasi maan elinkeinoelämää. Tätä perusteltiin paitsi kotimaisen elokuvatuotannon edistämisellä myös kotimaisen elinkeinoelämän tunnetuksi tekemisellä ja matkailun edistämisellä. 
Sotavuosien poikkeusolot lujittivat erityisesti kotimaisen elokuvan asemaa suuren yleisön vapaa-ajanviettotottumuksissa, kun kilpailevien huvittelumahdollisuuksien tarjonta oli vähäistä. Elokuvan suosiota ei vienyt edes verotuksen ankaroituminen vuonna 1941, jolloin vero säädettiin koskemaan myös kotimaisia elokuvia, tosin ulkomaisten elokuvien veroa lievempänä. Lainmuutosta perusteltiin poikkeuksellisilla oloilla ja valtion kasvaneella rahantarpeella. Kotimaisen lyhytelokuvan suomaa alennusta tarkennettiin siten, että lyhytelokuvan piti olla kohtuulliset laatuvaatimukset täyttävä äänielokuva.

Jatkosodan aikana lakia muutettiin. Tiede- ja opetuselokuvat säilyivät verovapaina, muutoin verotus tuli entistä ankarammaksi. Huviverotus säilyi sotien jälkeenkin varsin ankarana, mutta 1950-luvun alussa sitä lievennettiin. Kokonaan verottomiksi säädettiin siveellisesti ja taiteellisesti korkeatasoiset sekä kohtuulliset tekniset vaatimukset täyttävät Suomessa valmistetut kokoillan äänielokuvat. Toisaalta 1950-luvun puolivälissä kotimaisten elokuvatarkastamon heikkotasoisiksi luokittelemien elokuvien vero korotettiin 30 \%:ksi ja ulkomaisten heikkotasoisten filmien vero peräti $50 \%$ :ksi.

1950-luvun puolivälissä tuli voimaan ns. pienten paikkakuntien veronhuojennus: vero oli normaalia alempi, jos elokuva esitettiin maalaiskunnassa tai enintään 4000 asukkaan kaupungissa tai kauppalassa. Elokuvaveron fiskaalinenkin merkitys oli 1950-luvulla huomattava.

\subsection{0- ja 1970-luvut}

Kotimainen elokuvatuotanto joutui 1950-luvun lopulla taloudellisiin vaikeuksiin, ja elokuvien huviverotusta kevennettiin. Elokuvateattereissa kävijöiden määrä kuitenkin aleni pääasiassa televisioiden yleistymisen vuoksi. Vuonna 1964 hallitus katsoi, ettei ollut syytä poistaa elokuvien verotusta kokonaan. Säädettiin elokuvaverolaki, jossa elokuvien verotusta alennettiin ja elokuvat jaettiin kahteen ryhmään. Normaaliksi veroksi tuli $10 \%$, mutta heikkotasoisiksi luonnehdittujen (seksi- ja väkivaltaelokuvien) veroksi $30 \%$. Elokuvaveroa käytettiin kotimaisen elokuvatuotannon avustamiseen. Tämä uusi laki romahdutti veron tuoton, ja vuoden 1969 lopulla opetusministeriö ja 
elokuva-alan järjestöt sopivat Suomen elokuvasäätiön perustamisesta. Säätiön rahoitukseen liittyen elokuvaverolakiin lisättiin säännös, jonka mukaan veroa alennettiin, jos näytännön toimeenpanija sitoutui suorittamaan elokuvasäätiölle tietyn osan näytännön pääsymaksusta. Säätiöratkaisun jälkeen veron tuotto laski entisestäänkin. Elokuvaveroa kertyi 1970-luvulla lähinnä vain seksielokuvien esittämisestä niihin keskittyneissä elokuvateattereissa.

\subsection{Huviverotuksen kumoaminen 1980-luvun alussa}

Ravintolaelinkeinon elvyttämistoimenpiteenä luovuttiin keväällä 1979 ravitsemisliikkeiden aukioloajan ja tarjoilun pidentämistä koskevien lupien leimaverosta sekä tanssi-, revyy- ja muiden niihin verrattavien ohjelmien lupapäätöksistä perittävästä leimaverosta, joka oli tavallaan korvannut näiden tilaisuuksien huviveron.

Kesällä 1980 hallitus antoi esityksen huviverosäännösten muuttamisesta. Esityksen perustelujen mukaan $80 \%$ huviveron tuotosta muodostui yleishyödyllisten yhteisöjen järjestämien tanssitilaisuuksien pääsylipuista suoritettavasta verosta. Hallitus esitti huviveron poistamista yleishyödyllisten yhteisöjen toimeenpanemien tanssien pääsylipuilta, mutta valtiovarainvaliokunta ehdotti koko huviverotuksen poistamista. Huviverotuksen kumoava leimaverolain muutos hyväksyttiin tämän mukaisesti, ja se tuli voimaan vuoden 1981 alusta.

\subsection{Elokuvaveron hiipuminen 1980-luvulla ja kumoaminen vuonna 1994}

Valtiovarainministeriö asetti vuoden 1981 alussa työryhmän selvittämään, olisiko huviverosta luopumisen vuoksi aiheellista kumota myös elokuvaverotus. Työryhmä totesi elokuvaveroa kertyvän käytännössä vain 30 \%:n elokuvien (seksi- ja väkivaltaelokuvat) esittämisestä. Veron tuotto oli vähäinen, joten veron kumoamisella ei siltä kannalta 
ollut merkitystä. Koska 30 \%:n elokuvavero oli merkittävä kulttuuripoliittinen elokuvien esitys- ja levitystoiminnan säätelykeino, olisi elokuvaverolain kumoaminen työryhmän mielestä merkinnyt supistusta yhteiskunnan mahdollisuuksiin rajoittaa heikkotasoisten elokuvien esittämistä. Työryhmä katsoi, että jos elokuvavero poistettaisiin, pitäisi elokuvien ennakkotarkastusperusteita laajentaa. ${ }^{154}$ Työryhmä totesi myös, että Suomen elokuvasäätiön rahoitus oli säätiömaksun tuoton kautta olennaisesti kytketty elokuvaverolakiin. Työryhmä ei pitänyt tarkoituksenmukaisena kumota lakia.

Elokuvaveron tuotto hupeni 1980-luvun puolivälistä alkaen niin, että vuonna 1992 se oli enää 22000 markkaa. Se johtui mm. videolaitteiden yleistymisestä: seksielokuvien katselu siirtyi elokuvateattereista koteihin. Vuonna 1994 elokuvaverotus kumottiin. Hallituksen esityksessä todettiin, että rangaistusveron merkitys elokuvateattereiden ohjelmiston laatuun vaikuttavana tekijänä oli menettänyt merkityksensä. Säätiömaksulla ei ollut enää Suomen elokuvasäätiön talouden kannalta samaa merkitystä kuin aikaisemmin, sillä maksu kattoi vain vähäisen osan säätiön rahoituksesta. Eduskunnalle oli annettu esitys arvonlisäverolaiksi, ja siinä ehdotettiin elokuvanäytöksistä suoritettavaksi arvonlisäveroa. Kun ei pidetty kohtuullisena, että elokuvateatterit olisivat joutuneet suorittamaan myös säätiömaksua, elokuvaverosta luovuttiin. Elokuvasäätiön toiminta rahoitettiin osoittamalla sille valtion talousarviossa määräraha.

154 Vuonna 1988 joutuivat 30 \%:n veroluokkaan seuraavat elokuvat: Ruotsittaret Ibizalla, Adam \& Nicole, Polttava himo, Come play with me, Vaalea kuuma, Likainen Harry, Lemmenjanoiset nymfot, Tarjoan itseni sinulle, Tuhansien nautintojen talo, Mobilhouse Girls, Molly, Newman's Law, Haluatko rakastella kanssani, Läimäys, Intohimon orjattaret, Kiihkeät kaunottaret, Thrill Seekers, Väkivallan vihollinen 3, Pahuuden yö, Ennustus. 


\section{Arvonlisäverotus ja tulliverotus ${ }^{155}$}

\subsection{Yleisen kulutusverotuksen historiasta ${ }^{156}$}

Yleisen kulutusverotuksen katsotaan alkaneen, kun I maailmansota finanssitarpeineen johti ensin Saksassa (vuonna 1916) ja pian sen jälkeen muissakin maissa liikevaihtoveron käyttöön ottamiseen.

Suomessa liikevaihtoverotus otettiin käyttöön vuonna 1941, kun ulkomaankauppa oli sodan takia tyrehtynyt ja valtiolle tärkeän tulonlähteen muodostaneet tullitulot olivat romahtaneet. Liikevaihtoverotuksemme uudistui merkittävästi vuoden 1951 alussa.

Liikevaihtoverotusta kehitettiin arvonlisäverotuksen suuntaan vuonna 1964 voimaan tulleella uudella liikevaihtoverolailla. Siirryttiin järjestelmään, jossa vero kannettiin taloudellisen vaihdannan kaikissa vaiheissa tuotteelle muodostuneesta arvonlisästä. Soveltamisalan ulkopuolelle jäi kuitenkin vielä suuri osa palveluja. Liikevaihtoverotus uudistettiin 1.10.1991 voimaan tulleella uudella lailla. Järjestelmää selkeytettiin, ja se muutettiin vastaamaan ajan vaatimuksia sekä kansainvälistä käytäntöä.

Pitkään vireillä ollut hanke siirtyä laajapohjaiseen arvonlisäverotukseen konkretisoitui, kun asia otettiin vuonna 1991 hallitusohjelmaan.

155 Arvonlisäverotuksesta ks. Juanto - Punavaara - Saukko Arvonlisäverotus ja muu kulutusverotus (2018).

156 Tarkemmin esim. Linnakangas Suomen kulutusverotuksen historia ja veneveron haaksirikko (2017). 
Hallitus antoi kesäkuussa 1993 eduskunnalle esityksen arvonlisäverolaiksi, ja arvonlisäverolaki tuli voimaan 1.6.1994. Lakia muutettiin perusteellisesti vuoden 1995 alusta, kun Suomesta tuli EU:n jäsen ja osa sisämarkkina-aluetta. Seuraavassa selvitetään taiteen tai taiteilijoiden asemaa nykyisten arvonlisäverosäännösten valossa.

\subsection{Pakollinen ja vapaaehtoinen arvonlisäverovelvollisuus}

Verovelvollisuuden edellytyksenä arvonlisäverotuksessa on, että myynti tapahtuu liiketoiminnan muodossa (AVL 1 \$). Käytännössä liiketoiminnan muodossa tapahtuvana pidetään ansiotarkoituksessa tapahtuvaa, jatkuvaa, ulospäin suuntautuvaa ja itsenäistä toimintaa, johon liittyy tavanomainen yrittäjäriski. Myynnin ei katsota tapahtuvan liiketoiminnan muodossa, jos siitä saatu vastike on ennakkoperintälaissa tarkoitettua palkkaa.

Vähäinen toiminta on rajattu pakollisen verovelvollisuuden ulkopuolelle. Myyjä ei ole verovelvollinen, jos tilikauden liikevaihto on enintään 15000 euroa, ellei häntä ole hänen oman

ilmoituksensa perusteella merkitty verovelvolliseksi (AVL 3 ja 12 \$). Hakeutuminen arvonlisäverovelvolliseksi voi olla kannattavaa suurten vähennysten vuoksi ja silloin, kun myynti tapahtuu arvonlisäverovelvollisille, jotka saavat vähentää hankintoihinsa sisältyvän arvonlisäveron.

Tuloverolaissa tarkoitettu yleishyödyllinen yhteisö on AVL 4 \$:n mukaan verovelvollinen vain, jos sen harjoittamasta toiminnasta saatua tuloa pidetään tuloverolain mukaan yhteisön veronalaisena elinkeinotulona. Kytkentä tuloverokohteluun on merkittävä; sen ansiosta yleishyödyllisten yhteisöjen ei yleensä tarvitse maksaa arvonlisäveroa mm. huvitilaisuuksista. Vaikka yleishyödyllinen yhteisö ei AVL $4 \$$ huomioon ottaen olisi arvonlisäverovelvollinen, voi se halutessaan hakeutua liiketoiminnastaan arvonlisäverovelvolliseksi (AVL $12 \$$ ).

KHO 15.2.2019 T 546. Ennakkoratkaisun hakija oli yleishyödyllisenä yhteisönä pidettävä itsenäinen julkisoikeudellinen säätiö, jonka toiminta 
perustui lakiin. Säätiö harjoitti näyttely- ja taidemuseotoimintaa sekä huolehti sille laissa säädetyistä tehtävistä. Toimintaa harjoitettiin pääasiassa valtion varoin. Säätiön museo- ja näyttelytoiminnan tuotoilla katettiin n. $27 \%$ mainitun toiminnan kuluista. Asiassa oli kysymys siitä, oliko säätiöllä oikeus hakeutua arvonlisäverovelvolliseksi museo- ja näyttelytoiminnastaan. Kokonaisarvioinnin perusteella säätiön ei ollut katsottava harjoittavan toimintaansa AVL 1 \$:ssä tarkoitetulla tavalla liiketoiminnan muodossa. Koska yhteisestä arvonlisäverojärjestelmästä annetussa neuvoston direktiivissä 2006/112/EY ei ollut säännöksiä yleishyödyllisen yhteisön oikeudesta hakeutua vapaaehtoisesti verovelvolliseksi liiketoiminnastaan ja kysymyksessä oli siten vain kansallisesti noudatettava järjestelmä, mainitun direktiivin liiketoimintakäsitteellä ei ollut tulkintavaikutusta asiassa. Näin ollen säätiöllä ei ollut oikeutta hakeutua verovelvolliseksi museo- ja näyttelytoiminnastaan.

\subsection{Esiintymispalkkioiden ja tekijänoikeuskorvausten arvonlisäverollisuus}

\subsubsection{Verottomat ja verolliset suoritukset}

Esiintymispalkkioista ja eräistä immateriaalioikeuksista säädetään arvonlisäverolain 45 §:ssä nykyisin seuraavasti:

Veroa ei suoriteta:

1) esiintyvän taiteilijan tai muun julkisen esiintyjän ja urheilijan palkkiosta;

2) tilaisuuden järjestäjälle luovutettavaksi tarkoitetun 1 kohdassa mainitun esiintyjän esityksen myynnistä;

3) 1 kohdassa tarkoitetun esiintyjän esityksen ääni- tai kuvatallennusta koskevan oikeuden luovuttamisesta tai oikeuden perusteella saadusta korvauksesta;

4) tekijänoikeuslain (494/1961) 1, 4 tai 5:ssä tarkoitetun oikeuden luovuttamisesta tai oikeuden perusteella saadusta korvauksesta;

5) tekijänoikeuslakiin perustuvan oikeuden luovuttamisesta tai oikeuden perusteella saadusta korvauksesta tekijänoikeuslain 19 a, 26, 26 a, 26 i

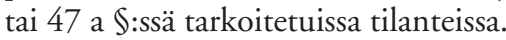

Edellä 1 momentin 3 ja 4 kohdassa tarkoitettu verottomuus ei koske valokuvaa, mainosteosta, karttaa tai sen valmistamiseen käytettyä aineistoa, 
automaattista tietojenkäsittelyjärjestelmää tai tietokoneohjelmaa koskevan oikeuden eikä elokuvan, video-ohjelman tai muun sellaisen ohjelman esittämisoikeuden luovuttamista.

Edellä 1 momentin 3-5 kohdassa tarkoitettu verottomuus ei koske tekijänoikeuden haltijoita edustavan järjestön oikeuden luovuttamisesta tai oikeuden perusteella saamia korvauksia.

Esiintymispalkkioiden ja tekijänoikeuskorvausten arvonlisäverottamista on pidetty hallinnollisista syistä ongelmallisena. Julkisen esiintyjän, kirjailijan ja säveltäjän toiminta ei useinkaan tapahdu liiketoiminnan muodossa, vaan toiminnasta saadut korvaukset voidaan rinnastaa palkkaan. Esiintymis- ja tekijänoikeuskorvaukset tulevat lisäksi hyvin usein verotetuiksi osana kulutukseen myytävän hyödykkeen myyntihintaa, esimerkiksi tilaisuuden pääsymaksussa taikka kirjan tai äänilevyn myyntihinnassa. Korvauksen verottamatta jääminen ei siis merkitse sitä, että esiintyjän tai taiteilijan luoma arvonlisä jäisi kokonaan verottamatta.

Esiintyjän palkkiot ja esityksen myynti. Arvonlisäveroa ei AVL 45.1 \$:n 1 kohdan mukaan suoriteta esiintyvän taiteilijan tai muun julkisen esiintyjän ja urheilijan palkkioista. Esiintyviä taiteilijoita ovat esimerkiksi laulaja, soittaja, näyttelijä ja lausuja. Veroa ei suoriteta myöskään tilaisuuden järjestäjälle luovutettavaksi tarkoitetun esiintyjän esityksen myynnistä (AVL 45.1 \$:n 2 kohta).

Ohjelmatoimistojen ja vastaavien palkkalistoilla olevien esiintyjien välitystoimintaa pidetään säännöksessä tarkoitettuna verottomana esityksen myyntinä. Myös ohjelmatoimistojen väliset myynnit ennen niiden myyntiä tilaisuuden järjestäjille ovat verottomia. Veroton esityksen myynti on kysymyksessä myös silloin, kun esiintyjä harjoittaa toimintaansa yhtiömuodossa. Esityksen myyminen televisio- tai radiolähetyksen lähettäjäyrityksellekin on veroton.

Tekijänoikeudet. Veroa ei suoriteta AVL 45.1 \$:n 1 kohdassa tarkoitetun esiintyjän esityksen ääni- ja kuvatallennusta koskevan oikeuden luovuttamisesta tai oikeuden perusteella saadusta korvauksesta (AVL 45.1 §:n 3 kohta). Verottomuus koskee esimerkiksi levy-yhtiön muusikoille maksamia korvauksia. Veroa ei suoriteta myöskään tekijänoikeuslain 1, 4 tai 5 §:ssä tarkoitetun oikeuden eli kirjallisen tai taiteellisen teoksen tekijänoikeuden luovuttamisesta tai sellaisen oikeuden perusteella saadusta korvauksesta (AVL 45.1 §:n 4 kohta). 
Verottomuus koskee myös tekijänoikeuslain 4 \:ssä tarkoitettuja käännöstöitä ja 5 §:ssä tarkoitettuja kirjallisia kokoomateoksia.

KHO 2012:5. Musiikkiyhtyeen jäsenet olivat luovuttaneet esitystensä tallennusoikeuden A Oy:lle, joka oli tuottanut yhtyeen esityksistä masternauhan. A Oy oli tehnyt levy-yhtiön kanssa sopimuksen, jolla se luovutti masternauhan käyttöoikeuden levy-yhtiölle levynvalmistusprosessia varten. Sopimukseen sisältyi mm. oikeus valmistaa tallenteesta äänilevyjä sekä myydä, jaella, mainostaa ja antaa niitä vuokralle. A Oy:n tuottajana luovuttamaa mastertallenteen käyttö- ja kopiointioikeutta oli pidettävä tekijänoikeuslain 46 \$:ssä tarkoitettuna oikeutena, jota ei ollut erikseen säädetty AVL 45 \$:ssä verottomaksi. Koska A Oy:n masternauhan käyttöoikeuden luovutuksen perusteella laskuttamia lisenssikorvauksia oli pidettävä verollisena palvelun myyntinä, yhtiöllä oli oikeus vähentää masternauhan tuotanto-, masterointi- ja äänityskustannuksiin sisältyneet arvonlisäverot.

Tekijänoikeuskorvaukset olivat aikaisemmin verottomia myös tekijänoikeuden haltijoita edustavan etujärjestön (tekijänoikeusjärjestön) saamina. Vuoden 2009 alusta edellä käsitellyt AVL 45.1 §:n 3-5 kohdissa säädetyt verottomuudet eivät ole enää koskeneet tekijänoikeuden haltijoita edustavan järjestön oikeuden luovuttamisesta tai oikeuden perusteella saamia korvauksia. ${ }^{157}$ Lainmuutosta perusteltiin hallituksen esityksessä 159/2008 seuraavasti:

Tekijänoikeusjärjestöjen kansainvälisen kilpailukyvyn parantamiseksi ja neutraalisuuden lisäämiseksi tekijänkorvausten arvonlisäverotusta ehdotetaan muutettavaksi siten, että tekijänoikeudenhaltijoita edustavien järjestöjen saamat tekijänkorvaukset saatetaan verollisiksi. Tekijöiden ja esiintyjien saamat korvaukset säilyisivät sitä vastoin nykyiseen tapaan verottomina.

Ehdotus merkitsisi sitä, että tekijänoikeusjärjestöt olisivat arvonlisäverovelvollisia esiintyvän taiteilijan tai muun julkisen esiintyjän esityksen ääni- tai kuvatallennusta koskevan oikeuden luovuttamisesta taikka oikeuden perusteella saaduista korvauksista sekä tekijän tekijänoikeuslain

157 KHO 2017:93. Tekijänoikeuden haltijoita edustavien järjestöjen valtiolta tekijänoikeuslain 26 a \$:n nojalla saamia yksityisen kopioinnin hyvityksiä ei ollut pidettävä arvonlisäveron soveltamisalaan kuuluvana palvelun myynnistä suoritettuna vastikkeena. Näin ollen järjestöjen ei ollut suoritettava arvonlisäveroa saamastaan hyvityksestä. Äänestys 4-1. 
1, 4 tai 5 §:ssä tarkoitetun oikeuden luovuttamisesta tai oikeuden perusteella saaduista korvauksista. Sama koskisi tekijänoikeusjärjestön tekijänoikeuksien yhteisvalvonnan piirissä olevasta teosten jälkikäytöstä käyttäjiltä saamia korvauksia tekijänoikeuslain 19 a, 26, 26 a, 26 i tai 47 a §:ssä tarkoitetuissa tilanteissa.

Arvonlisäverovelvollinen tekijänoikeusjärjestö veloittaisi tekijänoikeuskorvaukset tekijänoikeuksien käyttäjiltä omana verollisena myyntinään. Se saisi vastaavasti yleisten sääntöjen mukaan vähentää omiin hankintoihinsa sisältyvän arvonlisäveron, kun hankinnat tapahtuvat sen verollista oikeuksien hallinnointia varten eli tekijänoikeuksien luovutuksiin ja korvausten veloittamiseen, valvontaan sekä korvausten tilityksiin tekijänoikeudenhaltijoille ja tekijöiden yhteisiin tarkoituksiin liittyen. Tekijänoikeuksien käyttäjät voisivat vähentää korvaukseen sisältyvän veron, kun kyse on niiden vähennykseen oikeuttavaa liiketoimintaa varten tapahtuneesta hankinnasta.

Tekijänkorvausten verollisuutta ei ehdoteta laajennettavaksi laajemmin. Ehdotus ei siten vaikuta muiden tekijänoikeuteen perustuvien korvausten saajien, kuten säveltäjien, kirjailijoiden ja esittävien taiteilijoiden sekä kustantajien, äänilevy-yhtiöiden ja elokuvatuottajien arvonlisäverokohteluun.

Myös tekijänoikeudenhaltijoille tilitettävät korvaukset ja tekijänoikeudenhaltijoiden yhteisiin tarkoituksiin käytettäväksi tarkoitetut korvaukset tekijänoikeuslain 19 a, 26, 26 a, 26 i tai 47 a \$:ssä tarkoitetuissa tilanteissa olisivat nykyiseen tapaan verottomia riippumatta siitä, onko korvauksen saajana tekijä, esittävä taiteilija, äänitetuottaja tai elokuvatuottaja.

Tekijänoikeudenhaltijoita edustavien järjestöjen saamiin tekijänkorvauksiin ehdotetaan sovellettavaksi alennettua verokantaa. Alennetun verokannan soveltaminen pienentäisi verorasitusta niissä tilanteissa, joissa korvausten maksajalla ei ole vähennysoikeutta ja joissa arvonlisävero muodostuu kustannukseksi. Tämä koskisi mm. seurakuntien ja yleishyödyllisten yhteisöjen maksamia korvauksia.

Nykyisessä verotuskäytännössä tekijänoikeusjärjestöt on katsottu tuloverolaissa tarkoitetuiksi yleishyödyllisiksi yhteisöiksi ja niiden tekijänoikeuksien hallinnoinnista saamaa tuloa ei ole pidetty tuloverotuksessa elinkeinotulona. Oikeustila ei tältä osin muuttuisi tämän lainsäädäntöehdotuksen johdosta. Järjestöjen harjoittama tekijänoikeuksien hallinnointi säilyisi siten tämän lainmuutoksen voimaan tullessa nykyisen verotuskäytännön ja arvonlisäverolain $4 \$$ :n perusteella verottomana, ellei järjestö 12 \$:n perusteella ole hakeutunut tai hakeudu toiminnastaan verovelvolliseksi. Tekijänoikeusjärjestöjen verokohtelu voi kuitenkin tulla jatkossa uudelleen arvioitavaksi.

Ehdotus lisäisi verotuottoa vähäisessä määrin. Tekijänoikeusjärjestöt laskuttavat tekijänkorvaukset yleensä sellaisilta tahoilta, joilla on arvonlisäveron vähennysoikeus. Näiltä osin ehdotus ei vaikuta verotuloihin. 
Tekijänoikeusjärjestöjen laskutus sellaisilta korvausten maksajilta, joilla ei ole vähennysoikeutta, on vuosittain arviolta 14,6 miljoonaa euroa. Tästä määrästä valtion osuus on noin 10 miljoonaa euroa, kuntien osuus 1,9 miljoonaa euroa, seurakuntien osuus 0,7 miljoonaa euroa ja muiden osuus 2 miljoonaa euroa.

Tekijänkorvausten muuttuminen verolliseksi lisäisi verotuottoa noin 1 miljoonalla eurolla vuoden 2009 tasolla laskettuna. Tästä määrästä veronsaajan eli valtion maksama osuus on kuitenkin huomattava, 0,8 miljoonaa euroa. Tekijänoikeusjärjestöjen toiminnan muuttuessa verolliseksi ne voivat vähentää omiin hankintoihinsa sisältyvän arvonlisäveron. Järjestöjen nykyisellä kulurakenteella tämä merkitsisi verotulojen pienentymistä vuosittain yhteensä noin 0,7 miljoonalla eurolla. Kokonaisuutena verotulot kasvaisivat ehdotuksen johdosta siten noin 0,3 miljoonalla eurolla vuodessa.

AVL 45.1 \$:n 3 ja 4 kohdassa tarkoitettujen tekijänoikeusluovutusten verottomuus ei koske valokuvaa, mainosteosta, karttaa tai sen valmistamiseen tarkoitettua aineistoa, ATK-järjestelmää eikä tietokoneohjelmaa koskevan oikeuden luovuttamista (AVL 45.2 \$). Koska tällaiset tekijänoikeuden luovutukset liittyvät läheisesti normaaliin kaupalliseen toimintaan, ne ovat yleisten sääntöjen mukaan verollisia.

KHO 2001 T 1256. A Oy harjoitti aikakauslehtien julkaisutoimintaa, jota varten se oli ostanut B Oy:ltä lehdissä julkaistavia artikkeleita ja niihin liittyviä valokuvia. Lehtiartikkelin kirjoituspalkkio on AVL 45.1 \$:n 4 kohdan mukaan veroton ja valokuvan julkaisuoikeuden luovuttamisesta saatu korvaus AVL 45.2 \$:n mukaan verollinen. Kirjoitetusta tekstistä ja valokuvista muodostuvan lehtiartikkelin verokohtelu ei määräytynyt niin sanottua liittymisperiaatetta soveltaen yhtenäisesti vaan kummankin hyödykkeen osalta erikseen. Tämän vuoksi B Oy:n veloitus tuli jakaa siten, että kirjoituspalkkiot olivat verottomia ja valokuvien julkaisuoikeuksien luovutukset verollisia. A Oy:llä oli oikeus vähentää valokuvien julkaisuoikeuksien hankintahintaan sisältyvä vero.

Tekijänoikeusluovutusten verottomuus ei koske myöskään elokuvan eikä video-ohjelman tms. ohjelman esittämisoikeuden luovuttamista (AVL 45.2 §). Arvonlisäverojärjestelmässä mainoselokuvien verottaminen on perusteltua veron kertaantumisen estämiseksi. Myös muu liiketoiminnan muodossa tapahtuva elokuva- ja ääniohjelmatuotanto on verotuksen piirissä. Ohjelmantuottajan on siis suoritettava veroa elokuvan ja ääniohjelman esittämisoikeuksien luovuttamisesta 
saaduista korvauksista. Taiteilijoiden ohjelmatuottajilta veloittamat AVL 45 \$:n 3 ja 4 kohdissa tarkoitetut tekijänpalkkiot sitä vastoin ovat verottomia. Ohjelmatuotannossa käytettävät verollisina hankitut tuotantopanokset ovat vähennyskelpoisia.

\subsubsection{Esiintyvien taiteilijoiden vapaaehtoinen verovelvollisuus}

Lainmuutoksella, joka tuli voimaan 1.4.2019, AVL 12 \$:ää muutettiin niin, että liiketoiminnan harjoittaja voi sen estämättä, mitä lain 45.1 §:n 1 ja 2 kohdassa säädetään, tulla hakemuksesta verovelvolliseksi. Hakeutumismahdollisuuden säätämistä perusteltiin hallituksen esityksessä (HE 258/2018) seuraavasti:

Kulttuuri- ja viihdeala kokonaisuudessaan ja esittävien taiteilijoiden toiminta osana sitä on ammattimaistunut vahvasti esiintyvien taiteilijoiden verovapautta koskevan säännöksen säätämisen jälkeen. Liiketoimintaa harjoitetaan yhä useammin yhtiömuodossa. Esiintyvien taiteilijoiden ja ohjelmatoimistojen tapahtumien järjestäjille tarjoamat esiintymiskokonaisuudet sisältävät usein paitsi itse esiintymisen, myös esityksen vaatiman äänentoiston ja valaistuksen, näistä vastaavien teknikkojen palvelut, esiintyjäryhmän majoituksen ja kuljetuksen sekä muita vastaavia hankintoja. Kyseiset arvonlisäverolliset lisäpalvelut ostetaan ulkopuolisilta palveluntuottajilta. Esiintymispalkkioiden verottomuudesta johtuva hankintojen vähennyskelvottomuus aiheuttaa veron kertaantumista ja hankaloittaa viihde- ja kulttuurialan toimijoiden toimintaedellytyksiä.

Alan muutokset ja ammattimaistuminen koskevat myös esiintyvien taiteilijoiden asiakaskuntaa. Aiemmin esitysten ostajina toimivat usein erilaiset yhdistykset, kuten tanssilavatoimintaa harjoittavat urheiluseurat. Nykyisin ostajat ovat useimmiten arvonlisäverovelvollisia toimijoita, joilla on vähennysoikeus tekemistään hankinnoista.

Esityksen tavoitteena on muuttaa esiintymispalkkioiden arvonlisäverotusta vastaamaan alan keskuudessa ja markkinoilla tapahtunutta kehitystä. Arvonlisäverolakia ehdotetaan muutettavaksi siten, että esiintyville taiteilijoille ja muille julkisille esiintyjille ja urheilijoille sekä heidän esityksiään myyville tahoille annettaisiin oikeus päästä hakemuksesta verovelvolliseksi esiintymispalkkioiden ja tilaisuuden järjestäjälle luovutettujen esitysten myynnistä saatavien korvausten osalta. Hakeutumalla verovelvolliseksi tällaiset toimijat voisivat vähennysoikeuden avulla poistaa liiketoimintaansa liittyvien hankintojen sisältämän veron. Oikeus tulla hakemuksesta 
verovelvolliseksi antaisi esiintyville taiteilijoille ja ohjelmatoimistoille tasavertaiset toimintaedellytykset muiden alojen yrittäjien kanssa.

Esiintyvien taiteilijoiden ja muiden julkisten esiintyjien kenttä on monipuolinen. Jo musiikin alan sisällä esimerkiksi kevyen musiikin ja klassisen musiikin alan edustajien toimintaympäristö on erilainen. Esiintyvien taiteilijoiden lisäksi nykyinen esiintymispalkkioiden verottomuus koskee myös muita julkisia esiintyjiä, kuten näyttelijöitä ja juontajia, sekä urheilijoita. Esiintyvien taiteilijoiden ja muiden julkisten esiintyjien joukko ei ole yhtenäinen ja näin ollen intressit verovelvollisuuden suhteen voivat olla erilaiset. Tähän nähden pakollinen verovelvollisuus kaikille tämän alan toimijoille on ongelmallinen.

Verovelvolliseksi hakeutumista koskeva malli vastaisi periaatteiltaan arvonlisäverodirektiivissä ja -laissa pienyrityksille ja vähäisen toiminnan harjoittajille mahdollistettua vapaaehtoista verovelvollisuutta hakemuksen perusteella. Vapaaehtoinen verovelvollisuus ottaisi parhaiten huomioon kulttuurialan monimuotoisuuden antamalla jokaiselle esiintyvälle taiteilijalle harkinta- ja päätäntävallan siitä, onko verovelvolliseksi hakeutuminen hänen toiminnassaan taloudellisesti ja verotuksellisesti järkevä ratkaisu. Tämän vuoksi ehdotus perustuu tähän toteuttamismalliin.

Verovelvolliseksi hakeutuneen esiintyjän tai ohjelmatoimiston tulisi suorittaa vero kaikista arvonlisäverolain 45.1 \$:n 1 ja 2 kohdassa tarkoitetuista myynneistään ja muista mahdollisista verollisista myynneistään vastaavalla tavalla kuin muiden verollista toimintaa harjoittavien yritysten. Veroa olisi suoritettava myynneistä sekä arvonlisäverovelvollisille että ei-verovelvollisille ostajille. Arvonlisäverodirektiivin 391 artiklaan ei sisälly säännöstä, jonka mukaan esiintymistoiminnasta verovelvolliseksi hakeutuvan valintaoikeus voitaisiin rajata ostajan aseman perusteella. Direktiivissä ei ole säädetty myöskään pienyritysten osalta mahdollisuutta asettaa verovelvolliseksi hakeutumiselle tämänkaltaisia lisärajoituksia. Esiintymispalkkioiden ja -korvausten osalta verovelvollisiksi hakeutuvia ei ole syytä asettaa tässä suhteessa erilaiseen asemaan pienyritysten kanssa. Ostajan asemasta riippumaton malli on myös hallinnollisesti yksinkertainen ja selkeä.

Esiintyvä taiteilija tai ohjelmatoimisto merkittäisiin arvonlisäverovelvollisten rekisteriin hakemuksen tekemisestä lukien ja poistettaisiin rekisteristä hänen tekemänsä vaatimuksen perusteella AVL 173 ja 174 \$:ssä säädettyjen periaatteiden mukaisesti.

Esiintyvä taiteilija ja muu julkinen esiintyjä saa usein tuloja esiintymispalkkioiden lisäksi myös muista tulolähteistä, kuten erilaisista tekijänoikeuskorvauksista. Näiden verottomuudesta on säädetty AVL 45.1 §:n 3-5 kohdassa. Verovelvolliseksi hakeutumista ei säädettäisi mahdolliseksi näiden korvausten osalta. 
Esiintyvän taiteilijan esiintymispalkkiot saatetaan käsitellä ja maksaa henkilökohtaisena palkkatulona. AVL 1.4 \$:n mukaan myynnin ei katsota tapahtuvan liiketoiminnan muodossa, jos siitä saatu vastike on ennakkoperintälain 13 \$:ssä tarkoitettua palkkaa. Tuloverotuksessa noudatettavat periaatteet ja rajanvedot esimerkiksi palkkatulon ja työkorvauksen välillä soveltuisivat myös näiden korvausten arvonlisäverokäsittelyyn. Siltä osin kuin esiintymispalkkio tai muu esiintyvän taiteilijan saama korvaus käsiteltäisiin tuloverotuksessa palkkatulona, hakeutuminen verovelvolliseksi ei olisi mahdollista.

Edellä mainituilla periaatteilla olisi vaikutusta myös verovelvolliseksi hakeutuvan esiintyvän taiteilijan ja ohjelmatoimiston tekemien hankintojen vähennyskelpoisuuteen ja vähennysoikeuden jakamiseen. Yleisten vähennysoikeutta koskevien periaatteiden mukaisesti hankinnat eivät olisi vähennyskelpoisia siltä osin kuin ne liittyvät esiintyvän taiteilijan tai ohjelmatoimiston yksityiseen kulutukseen, verottomaan toimintaan kuten tekijänoikeuskorvauksiin sekä toimintaan, josta saatu vastike on palkkaa.

Lisäksi ehdotetaan, että edellä mainittujen esiintyjien ja ohjelmatoimistojen esiintymispalkkioihin ja tilaisuuden järjestäjille luovutettavien esitysten myyntiin sovellettaisiin alennettua $10 \%$ :n verokantaa, kuten muidenkin kulttuuripalvelujen osalta nykyisin sovelletaan.

\subsection{Taide-esineiden marginaaliverotus}

Jos verovelvollinen ostaa verollista liiketoimintaansa varten tavaraa arvonlisäverovelvolliselta myyjältä, tavaraan sisältyvä vero on vähennyskelpoinen yleisten säännösten mukaan. Marginaaliverotusmenettely (AVL 79 a-79 k \$) on erityissääntely, joka koskee käytettyjen tavaroiden lisäksi taide-, keräily- ja antiikkiesineitä, jotka ostetaan ei-verovelvollisilta. Ei ole pidetty asianmukaisena, että niistä jouduttaisiin suorittamaan täysi vero joka kerran niitä kaupasta myytäessä. Sen sijaan on katsottu olevan paikallaan, että kaupan perimästä myyntipalkkiosta peritään vero. Tällainen marginaaliverotusmenettely on vapaaehtoinen. Verovelvollinen voi valita myös yksinkertaistetun marginaaliverotusmenettelyn, jossa voittomarginaalina on verokauden voittomarginaali (AVL $79 \mathrm{k} \$$ ). 
AVL 79 b \$:n mukaan taide-esineillä tarkoitetaan seuraavia tullitariffissa luokiteltuja tavaroita:

1) taulut, alkuperäiskaiverrukset ja muut nimikkeeseen 9701 tai 9702 0000 kuuluvat esineet;

2) nimikkeeseen 97030000 kuuluvat veistokset ja niistä tekijän tai hänen oikeudenomistajiensa valvonnassa valmistamat jäljennökset enintään kahdeksan kappaleen määrään;

3) nimikkeeseen 58050000 kuuluvat kuvakudokset ja nimikkeeseen 63040000 kuuluvat seinävaatteet edellyttäen, että ne on tehty käsin taiteilijan alkuperäisluonnosten mukaan, enintään kahdeksana jäljennöksenä työtä kohden;

4) taiteilijan ottamat ja hänen vedostamansa tai hänen valvonnassaan vedostetut signeeratut ja numeroidut valokuvat, joiden määrä on rajoitettu kolmeenkymmeneen riippumatta koosta ja tukimateriaalista.

\subsection{Yleinen ja alennettu verokanta}

\subsubsection{Yleistä}

Yleinen arvonlisäverokanta on Suomessa nykyisin $24 \%$ verottomasta hinnasta laskettuna (EVL 84 \%). EU:n edellyttämä vähimmäistaso on $15 \%$. Eräisiin palveluihin ja tavaroihin sovelletaan erilaisista yhteiskuntapoliittisista syistä normaalia alempaa verokantaa. Jäsenvaltio voi soveltaa tiettyihin hyödykkeisiin yhtä tai kahta vähintään $5 \%$ :n suuruista verokantaa. Elintarvikkeet verotetaan meillä $14 \%$ :n verokannalla. Toista alempaa verokantaa, joka on nykyisin $10 \%$, sovelletaan lääkkeisiin, henkilökuljetuksiin, majoituspalveluihin jaliikuntapalveluihin sekä jäljempänä käsiteltäviin kulttuurihyödykkeisiin. 


\subsubsection{Kirjat}

Painotuotteiden kustantamista ja välitysliikkeiden epäkohtia tutkiva komitea ehdotti vuonna 1945, että "ala-arvoiselle" kirjallisuudelle pitäisi säätää erikoisvero, mutta ehdotus ei edennyt. ${ }^{158}$ 1950-luvulla liikevaihtovaihtoverosta vapaita olivat varsinaiseen kirjallisuuteen kuuluvat kirjat ja myös sanomalehdet, samoin aikakauslehdet, ajanvietelehtiä lukuun ottamatta. Ajanvietelehdiksi luokiteltiin mm. eräät miestenlehdet.

Nykyisin kirjoihin ${ }^{159}$ sovelletaan kulttuuripoliittisista syistä alennettua verokantaa, joka on tällä hetkellä $10 \%$ (AVL 85 a.1 §:n 7 kohta). Lakia on muutettu 1.7.2019 lukien siten, että sama verokanta koskee sekä fyysisellä alustalla olevaa että sähköisesti luovutettavaa kirjaa, samoin fyysisellä alustalla olevia ja sähköisesti luovutettavia sanoma- ja aikakauslehtiä. Alennetun verokannan piiriin kuuluvana julkaisuna ei pidetä pääasiallisesti mainoksia sisältävää julkaisua eikä pääasiallisesti videosisältöä tai kuunneltavaa musiikkia sisältävää julkaisua.

\subsubsection{Tekijänoikeusjärjestön saama tekijänoikeuteen liittyvä korvaus}

Tekijänoikeuden haltijoita edustavien järjestöjen jälkikäytöstä saamat korvaukset ovat olleet verollisia vuodesta 2009 alkaen, kuten edellä on selvitetty, ja niihin sovelletaan $10 \%$ :n verokantaa (AVL 85 a.1 §:n 10 kohta).

\subsubsection{Taide-esineet}

Vuoden 2002 loppuun Suomessa oli voimassa AVL $46 \$$, jonka mukaan tekijän ei ollut suoritettava arvonlisäveroa taide-esineen

158 Vuonna 2013 Lapin yliopistossa tarkastettu Laukan väitöskirja Kekkoslovakian kuninkaat - Hurriganes 1970-luvun suomalaisen kulttuurin tuotteena, tekijänä ja nostalgiana s. 72 .

159 Ks. myös Nurkkala Kirjan käsite arvonlisäverotuksessa, Verotus 1996 s. 284 ss., jossa selvitetään mm. sitä, montako sivua julkaisussa pitäisi vähintään olla, jotta kysymyksessä olisi kirja. 
myynnistä eikä välittäjän ollut suoritettava arvonlisäveroa tekijän omistaman taide-esineen välityksestä. Taide-esineiden edelleenmyynti ja muiden kuin tekijän omistamien taide-esineiden välitys oli normaalien sääntöjen mukaista verollista toimintaa.

Verovapaudella, joka oli säädetty kulttuuripoliittisista syistä, jatkettiin liikevaihtoverolain aikana syntynyttä käytäntöä. Liittyessään Euroopan unioniin Suomi neuvotteli itselleen taiteilijoita koskevan poikkeuksen, jonka perusteella verovapaus pidettiin voimassa. Poikkeus koski kuitenkin vain palveluja, ei tavaroita. EU-tuomioistuin katsoi tuomiossaan 7.3.2002, että Suomi ei ollut noudattanut velvoitteitaan, kun se oli pitänyt voimassa lainsäädännön, jolla vapautettiin verosta taide-esineiden tekijän itse tai välittäjän välityksellä suorittama taide-esineiden myynti sekä tekijän omistaman taide-esineen maahantuonti.

Suomi muutti arvonlisäverolakia vuodesta 2003 alkaen siten, että taide-esineiden myynti, välitys ja maahantuonti säädettiin verolliseksi. Kulttuuripoliittisista syistä verokannaksi säädettiin alennettu verokanta, joka on nykyisin $10 \%$. Alennettua verokantaa sovelletaan kuitenkin muun kuin maahantuonnin osalta vain silloin, kun myyjänä on tekijä tai hänen oikeudenomistajansa taikka satunnaisesti muu elinkeinonharjoittaja kuin AVL 79 a.3 \$:ssä tarkoitettua marginaaliverotusta soveltava verovelvollinen. Alennettua verokantaa ei sovelleta välityspalkkioon. Jos taas esimerkiksi galleria myy omissa nimissään taide-esineen omistajan lukuun, kyse on komissiokaupasta, jota verotetaan ikään kuin omistaja olisi myynyt esineen gallerialle ja galleria olisi myynyt sen edelleen ostajalle.

Taide-esine määritellään AVL 79 c :ssä, jota on selvitetty edellä marginaaliverotuksen yhteydessä.

\subsubsection{Kulttuuritilaisuuksien sisäänpääsymaksut}

Kulttuuri- ja viihdetilaisuuksien järjestäminen on verollista, jos toimintaa harjoitetaan liiketoiminnan muodossa. Yleishyödyllisten yhteisöjen järjestäminä nämä tilaisuudet ovat kuitenkin normaalisti verottomia AVL 4 \$:n perusteella. Ei-kaupallisten ja kaupallisten tilaisuuksien erilaisen verokohtelun lieventämiseksi verollisten tilaisuuksien pääsymaksut ovat alennetun, nykyisin $10 \%$ :n, verokannan 
piirissä (AVL 85 a.1 §:n 4 kohta). Alennettua verokantaa sovelletaan teatteri-, sirkus-, musiikki- ja tanssiesitysten, elokuvanäytösten, näyttelyiden ja museoiden sekä vastaavien kulttuuri- ja viihdetilaisuuksien tai laitosten pääsymaksuihin.

\subsubsection{Esiintyvien taiteilijoiden palkkiot}

Lainmuutoksella, joka tuli voimaan 1.7.2019, AVL 85 a.1 §:ään lisättiin 11 kohta, jonka mukaan alennetun $10 \%$ :n verokannan piiriin lisättiin esiintyvän taiteilijan tai muun julkisen esiintyjän ja urheilijan esityksen myynnistä saatava 45.1 §:n 1 ja 2 kohdassa tarkoitettu palkkio tai korvaus, jos liiketoiminnan harjoittaja on hakeutunut tästä toiminnasta verovelvolliseksi. Tämä on perusteltua, kun otetaan huomioon kulttuuri- ja viihdetilaisuuksien $10 \%$ :n verokanta.

\subsection{Kulttuuri- yms. palvelujen myyntimaa}

Arvonlisäveroa suoritetaan liiketoiminnan muodossa Suomessa tapahtuvasta tavaroiden ja palvelujen myynnistä sekä Suomessa tapahtuvasta tavaran maahantuonnista ja yhteisöhankinnasta. Arvonlisäverolain 5 luvussa säädetään myynnin tapahtumisesta Suomessa. Taiteen kannalta laissa on pari kiinnostavaa myyntimaasäännöstä.

Kulttuuri-, viihde- ja muita vastaavia palveluja koskee AVL 69 d \$: Elinkeinonharjoittajalle luovutettu oikeus pääsyyn opetus-, tiede-, kulttuuri-, viihde- ja urheilutilaisuuteen, messuille ja näyttelyyn ja muuhun vastaavaan tilaisuuteen sekä pääsyyn välittömästi liittyvä palvelu on myyty Suomessa, jos tilaisuus järjestetään täällä. Muulle kuin elinkeinonharjoittajalle luovutetut palvelut, jotka liittyvät opetukseen, tieteellisiin palveluihin, kulttuuri-, viihde- ja urheilutilaisuuksiin, messuihin ja näyttelyihin ja muihin vastaaviin palveluihin sekä niiden järjestämiseen, on myyty Suomessa, jos toiminta tapahtuu täällä.

Immateriaalipalveluja koskee AVL 69 h \$: Muulle kuin elinkeinonharjoittajalle luovutettua immateriaalipalvelua ei ole myyty Suomessa, jos palvelu luovutetaan ostajalle, joka on sijoittautunut Yhteisön 
ulkopuolelle tai jonka kotipaikka tai vakinainen asuinpaikka on Yhteisön ulkopuolella. Tässä tarkoitettuja palveluja ovat mm. tekijänoikeuden, patentin, lisenssin, tavaramerkin ja muiden sellaisten oikeuksien luovuttamiset.

Radio- ja televisiolähetyspalveluja sekä sähköisiä palveluja koskevat AVL 69 i $\$$ ja 69 j $\$$. Muulle kuin elinkeinonharjoittajalle luovutettu radio- ja televisiolähetyspalvelu, sähköinen palvelu tai telepalvelu on myyty Suomessa silloin, kun palvelu luovutetaan ostajalle, joka on sijoittautunut Suomeen tai jonka kotipaikka tai vakinainen asuinpaikka on Suomessa.

Tätä lainkohtaa ei sovelleta, jos:

1) myyjällä on Yhteisössä liiketoiminnan kotipaikka tai kiinteä toimipaikka vain yhdessä jäsenvaltiossa;

2) palvelu luovutetaan muulle kuin elinkeinonharjoittajalle, joka on sijoittautunut muuhun kuin 1 kohdassa tarkoitettuun jäsenvaltioon tai jonka kotipaikka tai vakinainen asuinpaikka on muussa jäsenvaltiossa kuin 1 kohdassa tarkoitetussa jäsenvaltiossa; ja

3) 2 kohdassa tarkoitettujen luovutusten arvonlisäveroton kokonaisarvo on kuluvana kalenterivuonna enintään 10000 euroa eikä tämä määrä ole ylittynyt edellisenäkään kalenterivuotena.

Sähköisillä palveluilla tarkoitetaan seuraavia sähköisesti suoritettavia palveluja: kuvien, kirjoitusten ja tietojen luovuttamista sekä tietokantojen antamista käyttöön; musiikin, elokuvien ja pelien sekä kulttuuri-, taide-, urheilu-, tiede- tai viihdelähetysten ja -tapahtumien tarjoamista.

\subsection{Tulliverotus}

\subsubsection{Tulliverotuksen historiaa}

Tulli on vanha kulutusverolaji. Ensimmäinen kirjallinen todiste tullinkannosta Ruotsissa on 1200-luvun puolivälistä. Kun Ruotsista 1600-luvulla alettiin tehdä suurvaltaa, sotakoneiston käynnissä pitämiseen tarvittavien lisätulojen hankkimiseksi säädettiin myös uusi tulli, pikkutulli. Sitä ei peritty ulkomaankaupasta, vaan sillä verotettiin kotimaankauppaa. 
Venäläiset pyrkivät jo Suomen sodan aikana rauhoittamaan suomalaisten mielialoja, jotta maan saattaminen Venäjän keisarin alaisuuteen sujuisi joustavasti. Maaliskuussa 1808 lakkautettiin kotimaan kaupan pikkutulli. Keisarin Suomelle vahvistama ensimmäinen oma tullitaksa tuli voimaan kesäkuussa 1812, ja vuonna 1900 valtio sai verotuloistaan $70 \%$ tulleista. I maailmansodan aikana tullitulot romahtivat, mutta sodan jälkeen ne kohosivati yli 50 \%:iin II maailmansodan aikana tullitulot jälleen romahtivat.

Sittemmin tehtyjen vapaakauppasopimusten vuoksi tullituottomme vähenivät entisestään. Vuoden 1995 alusta Suomesta tuli EU:n jäsen. EU:n jäsenmaiden välisessä kaupassa ei kanneta tulleja, ja EU:n ulkopuolelta tuotavien tavaroiden tullit ovat unionin eivätkä jäsenvaltion tuloja.

\subsubsection{Taideteosten tulli}

EU:n tullilainsäädäntö, joka sitoo myös Suomea, on hyvin yksityiskohtaista. Sen perustana on tullikoodeksi, jossa säädetään mm. tavaran alkuperästä ja tullausarvon ${ }^{160}$ määrittämisestä. EU:n yhdistetty nimikkeistö (CN) ja EU:n integroitu tariffi (TARIC) yhdessä muiden tullimääräysten kanssa muodostavat yhteisen tullitariffin. Tullitariffissa on myös monia tiettyihin maihin tai maaryhmiin sovellettavia etuetuusmääräyksiä. Taideteoksia koskevat erityisesti seuraavat nimikkeet: ${ }^{161}$

9701 Maalaukset, piirustukset ja pastellit, kokonaan käsin tehnyt, muut kuin nimikkeen 4006 piirustukset ja muut käsin maalatut tai käsin koristellut tavarat; kollaasit ja niiden kaltaiset koristetaulut 9702 Alkuperäiskaiverrukset, -painokset ja -litografiat

9703 Mistä aineesta tahansa valmistetut alkuperäisveistokset ja -patsaat (nimikettä ei sovelleta massatuotantona tehtyihin tavaroihin eikä kaupallisen luonteen omaaviin tavallisiin käsitöihin, vaikka ne olisivatkin taiteilijoiden suunnittelemia tai tekemiä).

160 Joidenkin tavaroiden osalta sovelletaan paljoustullia, jolloin tullimaksu voi määräytyä myös painon mukaan.

161 Nimikkeistöä hyödynnetään myös taide-esineiden arvonlisäverotuksessa (ks. edellä luku 6.4). 
6 Arvonlisäverotus ja tulliverotus

Taideteokset ovat yleensä tietyin edellytyksin tullittomia. Ainakin USA:ssa on tuomioistuimessakin riidelty siitä, onko jokin veistos taidetta vai ei. ${ }^{162}$

162 Esim. maailmankuulua ja kallista Bird in Space -nimistä veistosta koskenut kiista vuosina 1926-1927 (ks. siitä Wikipedia Bird in Space). 


\section{Arvonimivero}

\subsection{Sääntelyn historiasta}

Arvonimiä voidaan antaa henkilöille, jotka ovat kunnostautuneet hallitsijan palveluksessa tai muuten edistäneet yhteistä hyvää. Hallitsijalla itsellään on usein ollut suorastaan tolkuton määrä arvonimiä.

Perustuslakivaliokunta ehdotti vuoden 1919 hallitusmuodon 15 §:ksi seuraavaa: "Älköön tasavallassa annettako älköönkä käytettäkö aatelisarvoja, arvonimiä eikä ritarimerkkejä.” Se perusteli tittelien antamisen soveltuvan huonosti kansanvaltaan ja olevan omiaan edistämään ja ylläpitämään turhamaisuutta. Suuri valiokunta kuitenkin muutti pykälän muotoon "Älköön tasavallassa annettako aatelisarvoja eikä ritarimerkkejä.” Perustuslakivaliokunta hyväksyi 15 \$:n siinä muodossa kuin se lopulta säädettiin: "Älköön tasavallassa annettako aatelisarvoja älköönkä muita perinnöllisiä arvoja." Vasemmisto oli vastustanut ritarimerkkijärjestelmän hyväksymistä. Eduskunnan enemmistö taas oli pitänyt kiinni ritarimerkeistä, ja lopulta vasemmisto hyväksyi ne lehmänkauppana, kun hallitusmuodon 6 \$:ään samalla otettiin säännös: "Kansalaisten työvoima on valtakunnan erikoisessa suojeluksessa." Suomen nykyisessä perustuslaissa ei kielletä aatelisarvojen ja muiden perinnöllisten arvojen antamista, mutta kieltoa voidaan pitää itsestään selvänä lain $6 \$$ :n yhdenvertaisuusvaatimuksen takia.

Arvonimistä on verotettu useissa valtioissa. Meillä niistä verotettiin leimaverolain mukaan 2000-luvun alkuun asti, jolloin leimaverolain tilalle säädettiin laki arvonimistä suoritettavasta verosta. Avoimesta kirjeestä, jolla tasavallan presidentti myöntää arvonimistä annetussa 
tasavallan presidentin asetuksessa tarkoitetun arvonimen, suoritetaan veroa valtiolle. ${ }^{163}$ Arvonimivero ei ole tuloverotuksessa maksajalle vähennyskelpoinen meno eikä arvonimen saajalle veronalainen etu.

\subsection{Taiteilijoille sopivat arvonimet ja niiden hinta}

Taiteilijoille sopivia arvonimiä voivat olla esimerkiksi seuraavat (suluissa veromäärä): ${ }^{164}$

professori (12 000 tai 3000 euroa), kulttuurineuvos (8 700 tai 2200 euroa), balettineuvos, elokuvaneuvos, musiikkineuvos, taideneuvos ja teatterineuvos (6 200 tai 1550 euroa) sekä director cantus ja director musices (70 tai 50 euroa).

Professorin arvonimi on taiteilijoista myönnetty ainakin Lasse Pöystille. Veijo Baltzar on kulttuurineuvos ja Seija Simonen balettineuvos. Elokuvaneuvoksia ovat olleet mm. T. J. Särkkä, Kari Uusitalo ja Ere Kokkonen. Musiikkineuvoksen arvo on myönnetty mm. Lasse Pihlajamaalle, Seppo Hoville, Matti Heinivaholle, Ilkka Lipsaselle ja Kari "Epe" Heleniukselle. Teatterineuvoksen arvon ovat saaneet esimerkiksi Ritva Oksanen, Tapani Perttu, Kalle Holmberg, Matti Ranin ja Eila Roine. Arvonimien listalla uusi on taideneuvos. Se on suunnattu sellaisille ansioituneille kuvataiteilijoille, joiden kohdalla professorin arvonimen tutkimukselliset kriteerit eivät täyty.

Director cantus -arvonimen saajat ovat yleensä olleet kanttoreita, kapellimestareita ja laulunopettajia. Director musices -arvonimen saaneiden joukossa on ollut mm. kanttoriurkuri, laulunopettaja, kansakoulunopettaja, kuoronjohtaja, soittokunnan johtaja, käyrätorvisoittaja, bassoviulunsoittaja, viulutaiteilija, oboetaiteilija, kapellimestari, säveltäjä ja laulajatar.

163 Ainoastaan tasavallan presidentin myöntämistä arvonimistä maksetaan arvonimiveroa. Esim. sarjakuvaneuvoksen arvosta, jonka myöntää Suomen Sarjakuvaseura, veroa ei suoriteta.

164 Alempaa veroa peritään, jos arvonimen saaja on päätoimisessa virka- tai työsuhteessa taikka muussa siihen verrattavassa palvelussuhteessa valtioon, kuntaan tai kirkkoon. 


\section{Verojen vanhentuminen ja anteeksianto}

Verojen ja maksujen täytäntöönpanosta annetun lain 20 \$:n mukaan julkinen saatava vanhentuu yleensä viiden vuoden kuluttua sitä seuranneen vuoden alusta, jona se on määrätty tai maksuunpantu, ja muussa tapauksessa sitä seuranneen vuoden alusta, jona se on erääntynyt.

Lähtökohtana myös vero-oikeudessa on "duralex-periaate", jonka mukaan ankaraakin lakia on noudatettava (dura lex sed lex). ${ }^{165}$ Toisaalta mm. vanhoissa tuomarinohjeissa todetaan: "Mikä ei ole oikeus ja kohtuus, se ei saata olla lakikaan." Kohtuuden noudattaminen lieventää ja korjaa kaavamaisen yhdenmukaisuuden periaatteen jäykkyyttä. Kohtuullistamisessa on kyse kohtuuttomuuden poistamisesta siten, että yksittäistapauksen erityispiirteet otetaan huomioon.

Verotuksen yhteydessä kohtuullistamisella on tarkoitettu $\mathrm{mm}$. ilmiötä, josta yleisesti on käytetty nimitystä verosta vapauttaminen. ${ }^{166}$ Tuo termi on kuitenkin väritön, koska siitä ei ilmene, minkä vuoksi verosta vapautetaan. Usein on käytetty myös termiä veronhuojennus, mutta sekään ei ole hyvä ilmaus, koska veronhuojennuksista puhutaan yleisesti myös aivan muunlaisten verohelpotusten kohdalla.

165 Kohtuuttomaan ratkaisuun pakotettu tuomari saattaa kokea "Pilatus-ilmiön": tuntea halua pestä kätensä.

166 Linnakangas Verojen kohtuullistaminen (1987); Söderlund Oikeus ja kohtuus verotuksessa - Oikeustieteellinen tutkimus verovelvollisen oikeudesta saada ja veroviranomaisen velvollisuudesta myöntää harkinnanvaraisia veronhuojennuksia (2009); Räbinä - Myrsky - Myllymäki Verotusmenettelyn perusteet (2017) s. 371 ss. 
Verojen anteeksianto olisi osuvampi termi, vaikka sitä ei verolaeissa käytetä. Anteeksiannossa vero on aineellisten verosäännösten nojalla määrättävä, mutta huojennushakemuksen nojalla verovelvollinen vapautetaan veron maksuvelvollisuudesta kohtuussyistä. Yleissäännös tästä asiasta on nykyisen veronkantolain 47 §:ssä.

Verotuksen kohtuullistamissäännökset voivat tulla sovellettaviksi myös taiteilijoihin. Julkisuudessa on kerrottu mm. Vesa-Matti Loirin tapauksesta seuraavaa (Ilta-Sanomat, Viihde 5.1.2015):

Vesa-Matti Loiri kertoo Helsingin Sanomien Kuukausiliitteen haastattelussa saaneensa niskaansa jopa miljoonan markan verovelat jätettyään maksamatta verot vuosien varrella käteisenä saamistaan keikkapalkkioista. Lopulta rahat riittivät hädin tuskin koroista selviämiseen.

Loirin mukaan kierre katkesi vuonna 1988 hänen törmättyään taiteilijanuransa 25-vuotisjuhlassa Helsingin Kulttuuritalolla nuoreen valtiovarainministeriin Erkki Liikaseen, jolle paikalla ollut näyttelijä Eija Ahvo ehdotti Loirin velkojen anteeksiantoa. Asiasta Liikaseen olivat olleet yhteydessä myös Mainos-tv:n viihdepäällikkö Päiviö Pyysalo sekä työkaveri Spede Pasanen.

Loirin mukaan Liikanen ja Puolanne kutsuivat hänet myöhemmin eduskuntaan tapaamiseen, jossa sovittiin 150000 markan velkakorkojen anteeksiannosta. Loppua velkaa varten Loirille järjestettiin laina, jonka takasivat Liikanen, Pasanen, Mainos-tv sekä sanoittaja Vexi Salmi. Lopulta summa tuli kuitattua, mutta aikaa maksamiseen kului yli kymmenen vuotta.

Vuonna 1988 toisena valtiovarainministerinä toiminut Ulla Puolanne vahvistaa allekirjoittaneensa sopimuksen, jolla viihdetaiteilija Vesa-Matti Loirin mittavista veloista kertyneistä koroista annettiin merkittävä osa anteeksi erikoisjärjestelyn avulla.

- Omien muistikuvieni perusteella voin todeta, että näin tapahtui. Yhteydenotto tapahtui silloisen valtiovarainministeri Erkki Liikasen kautta, ja minä olen sellaisen lainajärjestelyn allekirjoittanut, Puolanne toteaa. - Eli jos Loiri haluaa kiittää jotain näistä helpotuksistaan, niin kiitos kuuluu hänelle. Liikasella oli paljon enemmän mielikuvitusta suhdetoiminnassa. Itse mietin vain, mihin rahat riittävät tai riittävätkö, entinen ministeri kuvailee.

Puolanne toteaa, ettei edes muista kyseistä tapaamista tai keskustelua järjestelystä Loirin kanssa. Hänen mukaansa päätös Loirin velkojen helpottamisesta kuitenkin valmisteltiin huolella virkamiesten toimesta, ja sitä puolsi myös valtiovarainministeriön vero-osaston johtaja. 
- Sen minä muistan, että kyllä sitä asiaa jonkin verran mietittiin myös ministeriön puolella, eikä se ollut mikään itsestäänselvyys, Puolanne sanoo.

Hän muistaa Loirin tapauksen olleen varsin monimutkainen ja koskeneen monia erilaisia verotusmuotoja.

- Sen takia asia kulki myös minun osastoni kautta, hän sanoo.

Puolanteen mukaan Loiri ei suinkaan ollut ainoa, joka noihin aikoihin pääsi vastaavan järjestelyn piiriin. Hänen mukaansa vastaavassa tilanteessa oli muitakin, sekä taiteilijoita että muunlaista työtä tekeviä.

- Siinä tehtiin sopimus siitä, kuinka velat hoidetaan, ja että osa annetaan anteeksi. Toinen mahdollisuus olisi ollut että asianomainen ei pysty maksamaan yhtään mitään. Kysymys oli siitä, saako valtio yhtään mitään, vai jääkö käteen nolla.

Puolanne toteaa järjestelyn olleen täysin lainmukainen.

- Tähän minulla ei ole sen enempää sanottavaa. Minä kannan vastuun, sillä siinä on myös allekirjoitukseni. 



\section{IV \\ Osa}

\section{Verotuksen taidesuhteen kehitys ja tulevaisuus}

\subsection{Taiteen julkisen tukemisen perustelut}

Joonas Stenmanin vuonna 2012 Tampereen yliopistossa tekemässä kansantaloustieteen gradussa "Taiteen julkinen rahoitus" on tutkittu perusteluja taiteen tukemiselle. Stenman on todennut mm.:

Varojen käyttäminen taiteen kehittämiseen ei ole pelkkää rahatuhlausta, vaan sillä voidaan parantaa yhteiskuntaa ja auttaa talouden kehittämistä. Oli kyseessä sitten demokraattinen maa, jossa vallan on tarkoitus olla kansalaisilla, tai millainen maa tahansa, on sen toiminnan kannalta tärkeää saada ihmiset kyseenalaistamaan asioita, ajattelemaan ja olemaan kriittisiä. Taide ja kulttuuri ovat voimia, jotka kannustavat toimimaan näin.

Taiteella voi olla tärkeä rooli yhteiskunnan muokkaajana, mutta se ei tarkoita automaattisesti sitä, että julkisen puolen varoja kannattaa käyttää taiteen tukemiseen. Myös yksityisen sektorin rooli on otettava huomioon. Markkinavetoisemmassa USA:ssa taiteen julkinen rahoitus on pienempää kuin Suomessa, jossa valtion rooli on suurempi. 
Taiteen rahoituksen pitäisi kohdistua lähinnä taiteilijoille itselleen, joten jakaessaan rahojaan köyhemmille taiteilijoille julkinen sektori voi toteuttaa tulojen uudelleenjaon tehtäväänsä. Taiteilijan, joka ei ilman avustuksia pystyisi toimimaan ammatissaan, ei tarvitse vaihtaa ammattia. Tarkoituksena ei ole kuitenkaan vain elättää menestymättömiä taiteilijoita, vaan tavoitteena on antaa uusille taiteilijoille mahdollisuus luoda jotain uutta ja siten edesauttaa innovaatioita ja luovuuden kasvamista. Köyhiä taiteilijoita varten on olemassa muitakin tuki-instrumentteja ja normaali sosiaaliturva.

Silloin kun taiteilijan tekemästä taiteesta hyötyy koko yhteiskunta, ei vain tuottaja ja ostaja, kyseessä on julkishyödyke. Julkinen tuotanto ei kuitenkaan sovi hyvin taiteen tukemiseen. Koska taiteen luonteeseen kuuluu, ettei se saa olla riippuvainen päättäjien toiminnasta eikä sen tarvitse olla linjassa yleisimpien mielipiteiden kanssa, julkisessa tuotannossa taiteen sisältö kärsii.

Taiteen positiivisia ulkoisvaikutuksia on kulttuurin säilyminen. Kulttuurinen aktiviteetti mahdollistaa kulttuurin kukoistamisen myös tulevaisuudessa, ja tavallaan on kysymys kulttuuriperinnön jättämisestä tuleville sukupolville. Toisena vaikutuksena on valtion tai jonkin muun alueen paikallisen identiteetin kasvattaminen. Valtion tai kaupungin menestyksestä kulttuurikeskuksena tai taiteilijoiden syntypaikkana voidaan tuntea ylpeyttä. Kolmanneksi voidaan mainita kulttuurin tarjonnan myötä tapahtuva ihmisten kuluttaman kulttuurin tason kasvu. Neljänneksi voidaan mainita se, että monet kulttuurihyödykkeet ovat julkishyödykkeitä; esimerkiksi julkiset installaatiot ja taideteoksen ovat hyödykkeitä, joiden kuluttamista on vaikea mitata ja hinnoittelu lähes mahdotonta. Viidenneksi on mainittava kulttuuriin sijoitettujen varojen aiheuttama talouden kerroinvaikutus; panostus kulttuuriin synnyttää taloudessa liiketoiminnan kasvua ja on eräänlainen finanssipolitiikan muoto.

Taiteella voi olla myös negatiivisia vaikutuksia. Taide voi normaalin kritiikin lisäksi pyrkiä vaikkapa tuhoamaan yhteiskunnan rakenteita. Mahdollisia negatiivisia ulkoisvaikutuksia on kuitenkin positiivisia vähemmän.

Taiteilija, kirjailija, ohjaaja, tutkija, kuvataiteen tohtori Teemu Mäki on Taiteilijalehden artikkelissa 29.8.2018 käsitellyt, miksi valtion pitäisi tukea taidetta. Hänen perustelunsa ovat seuraavanlaiset:

1. Taide on tärkeää, koska se luo kansallistunteen, kansallisen identiteetin, yhteenkuuluvaisuuden tunteen ja yhteisen kielen. Tämä ajatus on yleismaailmallisesti hyvin tavallinen, mutta Suomessa sillä on ollut aivan erityisen suuri merkitys. Suomi on nuori valtio ja väkiluvultaan pieni kansa. Globalisoituneessa maailmassa pienet ja paikalliset kulttuurit 
ovat jatkuvassa katoamisvaarassa. Voi jopa sanoa, että suomen kieli ja suomalainen taide katoavat vääjäämättä, ellei niitä tieten tahtoen tueta ja vaalita.

2. Taide on tärkeää, koska se jalostaa ihmistä. Taide sivistää ihmistä tiedollisesti ja jalostaa häntä uskonnollisesti ja moraalisesti. Parhaimmillaan taide todellakin saattaa onnistua jalostamaan meitä. Taiteella voidaan kyllä myös kannustaa vaikkapa muukalaisvihaan ja kansanmurhaan ja taidetta voidaan käyttää piittaamattomuuden ja omahyväisyyden lietsomiseen, mutta se ei poista taiteen tavallisempaa, hyvää potentiaalia. Taide ei ainoastaan välitä uskonnossa, filosofiassa ja politiikassa luotuja ja niissä hyviksi katsottuja ajatuksia ja tapoja, vaan luo entistä enemmän niitä myös itse.

3. Taide on tärkeä virkistysväline, jonka parissa ihminen saa levätä ja hetkeksi unohtaa ongelmansa. Ajanviete- tai ajantappotaiteen tuotantoon ei valtion tukea tarvita, mutta asia on toki monimutkainen, sillä taidelajeja ja taideteoksia ei voi simppelisti jakaa kahteen lokeroon, joista yhdessä on puhdas ajantappo- tai akkujenlataustaide ja toisessa jotain syvällisempää ja todellisuutta käsittelevää ja todellisuutta muuttavaa.

4. Taide on tärkeä kriittisen ajattelun muoto. Kriittinen ajattelu on toki myös kaiken tieteellisen ajattelun ja tutkimuksen kantava periaate, mutta tiede ei yksinään riitä. Faktojen lisäksi tarvitaan jotain muuta. Kriittinen taide ja tieteellinen perustutkimus ovat kriittisen ajattelun tärkeitä muotoja. Joskus ne kumpikin ovat ilmeisellä tavalla hyödyllisiä puuhia, joiden tuloksia voidaan välittömästi soveltaa jopa taloudellisesti voitokkailla tavoilla. Valtion ja kuntien - tai EU:n tai vastaavan - antama rahoitus on tärkeämpää kuin yksityinen, sillä se on - tai sen pitäisi olla - a) pitkäjänteisempää, b) kattavampaa, ja c) edustaa valtion tai muun vastaavan kautta kanavoituvaa kansan tahtoa eikä vain pienen ja vauraan eliitin näkemyksiä.

5. Taide on tärkeä talouden sektori. On alettu korostaa sitä, miten paljon taide työllistää ja lisää taloudellista toimeliaisuutta. Taiteen julkista rahoitusta on ruvettu puolustamaan sanoen että vaikka verorahoin usein rahoitetaan taloudellisesti tappiollista toimintaa, niin laajemmassa katsannossa ja välillisesti se silti vauhdittaa talouden pyörien pyörimistä. Tässä mielessä suomalaisen kulttuurin tukeminen verorahoilla on ihan samaa puuhaa kuin suomalaisen metsäteollisuuden, laivanrakennuksen, kaivostoiminnan, maatalouden tai tietotekniikkasektorin tukeminen. On oikein, että valtio investoi ja tukee kaupallisen suomalaisen taiteen tuotantoa ja vientiä, kunhan se tehdään lähinnä työ- ja elinkeinoministeriön varoista, eikä opetus- ja kulttuuriministeriön varoista. 
6. Taide on tärkeää, koska sillä on merkittäviä myönteisiä terveys- ja hyvinvointivaikutuksia. Viimeisen kymmenen tai kahdenkymmenen vuoden aikana on puhuttu paljon taiteen myönteisestä vaikutuksesta yksilön ja väestön terveyteen ja hyvinvointiin. Puhe taiteen terveys- ja hyvinvointivaikutuksista jakaa taiteilijoiden mielipiteet usein jyrkästi. Monet taiteilijat pelkäävät, että kaikelta taiteelta aletaan vaatia näyttöä myönteisistä terveys- ja hyvinvointivaikutuksista, että kohta rahaa ja elintilaa annetaan vain sellaiselle taiteelle, joka todistettavasti alentaa verenpainetta ja jonkin mittarin mukaan lisää keskivertoyleisön hyväntuulisuutta. Moni ajattelee myös, että hyvinvointivaikutuksista puhuminen on taiteen filosofian näkökulmasta lähtökohtaisesti väärin. Ja useimpien taiteilijoiden mielestä taiteen paras potentiaali on kuitenkin sen vapaudessa, siinä että taidetta tehdään silkasta taiteen tekemisen ilosta. Välittömiä terveys- tai hyvinvointivaikutuksia tavoittelevaa taidetta pitäisi rahoittaa pääosin sosiaali- ja terveysministeriön varoista, eikä opetus- ja kulttuuriministeriön varoista.

\subsection{Taiteen julkisen rahoituksen historiasta Suomessa 1830-luvulta 2020-luvulle}

Suomalaisen taiteilijatuen alku sijoittuu autonomian ajalle. ${ }^{167}$ Varhaisimman taiteilijatuen muodostivat 1830-luvulta lähtien taiteilijan eliniäksi annetut vuotuiset rahalahjat eli gratiaalit. Sellaisen saivat mm. C. L. Engel, J. L. Runeberg sekä Magnus ja Ferdinand von Wright.

Varsinaiset taiteenedistämismäärärahat tulivat valtion budjettiin 1860-luvulla. Vuonna 1863 senaatin käyttövaroista myönnettiin joitakin matka-apurahoja kuvataiteilijoille, ja seuraavana vuonna budjetissa oli määräraha kaunotaiteiden edistämiseen. Autonomian ajalla ja itsenäisyyden alussa taiteenedistämismäärärahaa käytettiin lähinnä taide- ja taiteilijaseurojen toiminnan tukemiseen.

Taidepalkinnot taiteilijatuen muotona syntyivät vuonna 1865, jolloin senaatti jakoi käyttövaroistaan kirjallisuuden, kaunokirjallisuuden ja kansantajuisen kirjallisuuden palkinnot. Kaunokirjallisuuden

167 Tarkemmin Rautiainen Suomalainen taiteilijatuki - Valtion suora ja välillinen taiteilijatuki taidetoimikuntien perustamisesta tähän päivään (2008) s. 22 ss. sekä Rautiainen Kuvataiteilijan oikeudellinen asema (2012) s. 179 ss. 
palkinnon sai Aleksis Kivi teoksella Nummisuutarit. Seuraavan kerran kirjailijapalkinto myönnettiin vasta vuonna 1881. Samoihin aikoihin palkintoja alettiin myöntää myös säveltaiteilijoille, kuvataiteilijoille ja näyttämötaiteilijoille.

Tärkeimmäksi taiteilijatuen muodoksi alkoi itsenäisyyden ajalla kehittyä taiteilijoiden työskentelyapurahajärjestelmä. Aluksi näitä suorituksia kutsuttiin valtion taiteilijaeläkkeiksi, vaikka ne oli tarkoitettu aktiivitaiteilijoille. Tällaisia etuja myönnettiin lähinnä kuvataiteilijoille, näyttämötaiteilijoille, kirjailijoille ja säveltaiteilijoille. Niitä saivat mm. Juhani Aho, Arvid Järnefelt, Robert Kajanus, Teuvo Pakkala, Kasimir Leino ja Jean Sibelius.

Taiteilijaeläkkeet muuntuivat II maailmansodan jälkeen pitkälti vanhuuseläkkeen luonteisiksi. Niitä korvaaviksi aktiivitaiteilijoiden tukimuodoiksi muodostuivat akateemikon virat ja akatemian myöntämät nuorten ja varttuneiden taiteilijoiden akatemia-apurahat.

Vuonna 1962 valtioneuvosto asetti Valtion taidekomitean kehittämään valtion taiteilijatukea. Komitea jätti mietintönsä vuonna 1965 . Tuon mietinnön toteutuneiden ehdotusten myötä Suomessa siirryttiin hyvinvointivaltiollisen taidepolitiikan aikakauteen.

Suoraan taiteilijatukeen käytetty määräraha oli esimerkiksi vuonna 2006 noin 20 miljoonaa euroa, joka jakautui taiteenlajeittain prosenttiosuuksina seuraavasti:

\begin{tabular}{|l|c|}
\hline Kirjallisuus & $24 \%$ \\
\hline Kuvataide & $23 \%$ \\
\hline Säveltaide & $10 \%$ \\
\hline Näyttämötaide & $10 \%$ \\
\hline Taideteollisuus & $7 \%$ \\
\hline Tanssitaide & $5 \%$ \\
\hline Valokuvataide & $5 \%$ \\
\hline Elokuvataide & $4 \%$ \\
\hline Rakennustaide & $3 \%$ \\
\hline Muut (mm. sirkustaide, mediataide, arvostelijat, lastenkulttuuri) & $9 \%$ \\
\hline
\end{tabular}


Vuoden 2021 valtion talousarvion loppusumma on noin 66 miljardia euroa. Siitä opetus- ja kulttuuriministeriön hallinnonalan määräraha on noin 7,4 miljardia euroa, josta taiteen ja kulttuurin osuus on noin 730 miljoonaa euroa sisältäen mm. seuraavat:

\begin{tabular}{|l|l|}
\hline - Rahapelitoiminnan tuotot taiteen edistämiseen & 190275000 \\
\hline $\begin{array}{l}\text { - Valtionosuus ja -avustus teattereiden, orkestereiden ja } \\
\text { museoiden käyttökustannuksiin }\end{array}$ & 129197000 \\
\hline $\begin{array}{l}\text { - Valtionosuus ja -avustus taiteiden perusopetuksen } \\
\text { käyttökustannuksiin }\end{array}$ & 92583000 \\
\hline - Taiteen edistämiskeskuksen toimintamenot & 84178000 \\
\hline - Ylimääräiset taiteilija- ja sanomalehtimieseläkkeet & 19619000 \\
\hline - Apurahat taiteilijoille, kirjailijoille ja kääntäjille & 17460000 \\
\hline
\end{tabular}

Opetus- ja kulttuuriministeriön julkaisusarjassa on 23.8.2021 ilmestynyt Ehdotus kansallisten taidelaitosten rahoitukseksi. Siinä työryhmä ehdottaa, että säädettäisiin laki valtion rahoituksesta kansallisille taidelaitoksille. Laki koskisi Kansallisgalleriaa, Suomen Kansallisoopperaa ja -balettia sekä Suomen Kansallisteatteria. Harkinnanvaraisen valtionavustuksen sijaan kansallisille taidelaitoksille myönnettäisiin lakisääteistä valtionrahoitusta laissa määriteltyihin tehtäviin. Rahoitus kytkettäisiin kustannustason kehitykseen. Lisäksi ehdotetaan, että niille kansallisille taidelaitoksille, jotka eivät ole arvonlisäverovelvollisia, korvataan niiden muuhun kuin liiketaloudelliseen toimintaan liittyvät arvonlisäverot.

\subsection{Verotuksen tavoitteista}

Veropolitiikan keskeiset tavoitteet palautuvat julkisen sektorin perustehtäviin. Voimavarojen kohdentamistehtävään kuuluu se, että julkinen valta hankkii rahoituksen omalle toiminnalleen. Tässä rahoituksessa on hallitseva asema veroilla, ja fiskaalinen tavoite eli tulojen kerryttäminen julkiselle sektorille onkin verotuksen olennaisin tavoite. Julkinen sektori käyttää verojärjestelmää fiskaalisen päätehtävän ohella lukuisten muiden tavoitteiden toteuttamiseen. Verotuksen ei-fiskaaliset tavoitteet liittyvät $\mathrm{mm}$. seuraaviin politiikkalohkoihin: jakopolitiikkaan, sosiaalipolitiikkaan, terveyspolitiikkaan, perhe- ja väestöpolitiikkaan, asuntopolitiikkaan, tulopolitiikkaan, 
työllisyyspolitiikkaan, kulttuuri- ja koulutuspolitiikkaan, elinkeinopolitiikkaan, kasvupolitiikkaan, aluepolitiikkaan, suhdannepolitiikkaan, turvallisuuspolitiikkaan ja ympäristöpolitiikkaan.

\subsection{Verotuet sekä niiden edut ja haitat verrattuna suoriin tukiin}

Verotusta lieventävät sääntelyt keventävät tiettyjen henkilöiden verotusta. Näin julkiselta sektorilta saamatta jääneet verotulot merkitsevät sitä, että julkinen valta antaa tukea verojärjestelmän kautta. Lähtökohtana verotukien osoittamisessa on voimassa olevan tai suunnitellun verolainsäädännön vertaaminen sellaiseen verojärjestelmään, joka mahdollisimman neutraalisti keräisi julkisen sektorin verotulot.

Kun joillekin verovelvollisille annetaan verotukea, verorasitus kohdentuu suurempana muihin verovelvollisiin. Tällöin verojärjestelmän sisällä tapahtuu tulonsiirto. Usein lähdetään kuitenkin siitä, että verotuki kasvattaa taloutta ja siten voi jopa kasvattaa verotuloja, jolloin ilman verotukea jääneidenkään verorasitus ei lisäänny. Verotuet eivät näy budjetin menomomenteilla, toisin kuin suorat tuet. Verotukien seuranta perustuu tukien määristä tehtyihin arvioihin.

Verotukien määrä ei ole meillä viime vuosina vähentynyt, päinvastoin. Veropohjan laajentaminen verotukia karsimalla on vaikeaa, koska verotukien lupaaminen on poliittisten päättäjien kannalta houkuttelevaa. Verotukien taloustieteellistä tutkimusta on tehty runsaasti. Usein on sekä meillä että muualla ehdotettu verotukien karsimista ja yleisten verokantojen alentamista - turhaan. Taiteeseen kohdistuu Suomessa hyvin paljon verotukia, kuten kirjan edellisestä osassa on selvitetty.

Verotukien etuina suoriin tukiin verrattuna voidaan pitää hallinnollista helppoutta sekä parempaa yhdenvertaisuutta ja oikeusturvaa, koska verotukia ei tarvitse samalla tavalla anoa kuin suoria tukia. Nykyaikaisessa verotuksessa harkintavalta on erittäin rajoitettua ja muutoksenhakuoikeus laajaa. Verotukien haittoina taas suoriin tukiin verrattuna voidaan pitää heikompaa osumatarkkuutta. 
Verotuen päinvastainen rinnakkaiskäsite on veropakote eli verosanktio, jolla tarkoitetaan poikkeamaa normaalia ankaramman verotuksen suuntaan. Sen jälkeen kun elokuvavero kumottiin, Suomessa ei ole ollut verosanktioita missään taidelajissa.

\subsection{Taiteen asema verotusta uudistettaessa}

Suuria verouudistuksia on itsenäisessä Suomessa toteutettu 20-30 vuoden välein. Ensimmäinen suuri uudistus toteutettiin 1920-luvun alussa, toinen 1940-luvun alussa, kolmas 1960-luvun lopussa ja neljäs 1980-luvun lopussa.

Kokoomuksen, SDP:n, RKP:n ja SMP:n keväällä 1987 muodostaman hallituksen ohjelmassa oli kokonaisverouudistuksen toteuttaminen. Tavoitteena oli eri tulolajien yhtäläinen verottaminen sekä vähennysjärjestelmän selkiyttäminen ja karsiminen. Lähtökohtana oli, että verotulot turvattaisiin eivätkä eri tuloluokkien keskimääräiset veroasteet muuttuisi. 1980-luvun lopun nousukaudella kokonaisverouudistus alkoi reippaasti, mutta kehitys rakoili jo 1990-luvun laman aikana. Myöhemmin on säädetty yhä uusia veropohjaa rapauttavia ja verojärjestelmää monimutkaistavia uusia verotukia ja entisten tukien soveltamisalaa on laajennettu.

Edellisestä kokonaisverouudistuksesta on kulunut jo yli 30 vuotta. Vaikka nykyisen verojärjestelmän kanssa pystyy vielä jotenkin elämään, olisi sopiva aika ottaa vuonna 2023 muodostettavan uuden hallituksen ohjelmaan kokonaisverouudistuksen toteuttaminen veropohjaa laajentamalla ja nimellisiä verokantoja vastaavasti alentamalla. Taiteen rahoitukseen vaikuttaisi ehkä merkittävimmin yleishyödyllisten yhteisöjen veronhuojennusten supistaminen esimerkiksi säätämällä sijoitustoiminnan tuotot veronalaisiksi.

Vaikka kokonaisverouudistusta lähdettäisiin toteuttamaan, taiteen verotukia tuskin merkittävästi leikattaisiin ainakaan ilman suorien tukien vastaavaa korottamista. Toisaalta taiteen asema verotuksessa on jo nyt niin edullinen, että taiteen ja taiteilijoiden verohelpotuksia ei liene tarvetta eikä valtiontaloudellisesti juuri mahdollistakaan lisätä. Vaikuttaa myös siltä, että nykyisin voimassa olevien verolakien 
tulkinnassa voidaan ottaa riittävästi huomioon taiteellisen toiminnan erityispiirteet, joten suuria paineita verosäännösten muuttamiseen tältä osin ei nyt liene.

\subsection{Veropoliittisen taiteen tulevaisuus - maailman onnellisin kansa}

Käsiteltyään Beatlesin 1960-luvulla julkaistua ”Taxman”-laulua ja Irwinin 1970-luvulla esitettyä haistattelulaulua Reijo Knuutinen totesi kirjassaan "Hyvät pahat verot" (2017), että noista ajoista maailmanmeno on monella tapaa muuttunut. Verotus on useassa maassa edelleen kireää, mutta muusikot ovat käsitelleet enemmän muita yhteiskunnan epäkohtia tai epäreiluina kokemiaan asioita kuin verotusta. Oma vaikutuksensa tähän voi Knuutisen mukaan olla nykyisillä verosuunnittelumahdollisuuksilla.

Yksi verosuunnittelukeino on muuttaa veroja pakoon alhaisemman verotuksen valtioon, mutta se ei ole aina ollut edes tarpeen. On voitu käyttää myös yhtiöittämisjärjestelyjä, joilla tuloja on ohjattu veroetuja antaviin valtioihin. Myös suomalaiset muusikot ovat yhtiöittäneet toimintojaan. Vaikka yhtiö ei osaa laulaa eikä soittaa, monen yhtiön liikevaihto on peräisin musiikin esittämisestä ja myymisestä. Taiteilijoiden vero-ongelmat ovat vähentyneet senkin vuoksi, että marginaaliveroja on huippuvuosista alennettu olennaisesti ja ennakkoperintää kehitetty niin, että ennakot aikaisempaa paremmin vastaavat lopullista veroa.

On vaikea löytää verotusta selvästi ylistävää taidetta sen jälkeen kun varmistui, että Hiski Salomaan "Vapauden kaihossa" ei laulettu verotuksesta vaan todellakin vapaudesta. Jonkinlaista mahtipontista ihailua kuitenkin ilmentää Tammerkosken sillalla oleva muinaista veronkantajaa esittävä patsas.

Suuri osa verotaiteesta on ollut hyvinkin ankaraa protestia verolakien säätäjiä ja verotuksen toimittajia vastaan. On arvosteltu hyvätuloisten ankaraa marginaaliveroa ja joskus myös köyhien vaikeaa asemaa verotuksessa. Muuten kritiikki on ollut usein kovin yleisluonteista napinaa. Monet taiteilijat näkyvät suhtautuneen verotukseen melko neutraalisti tai alistuvasti. Ainakin suomalainen verotaide on nykyisin paljolti viihdettä ilman selvăä pyrkimystä verolakien tai 
käytännön muuttamiseen. Viime aikoina olemme alkaneet kuulla sellaisiakin protestilauluja, joissa vaaditaan rikkaiden verovälttelyn lopettamista.

Muutokset eivät kuitenkaan toteudu yksin taiteellisin keinoin ja taiteilijoiden voimin. Suuriin uudistuksiin tarvitaan laajempaa tyytymättömyyttä, tietoa, joukkovoimaa ja uhkailemista. Vuosituhansien ajan maailmassa on vastustettu epäoikeudenmukaisiksi koettuja veroja kieltäytymällä veronmaksusta, ryhtymällä verokapinoihin ja jopa vallankumouksilla.

Jo Lallin 1150-luvun puolivälissä tekemä piispa Henrikin surma voidaan nähdä verokapinana. Myös 1500-luvun lopun nuijasodassa oli kysymys keskeisesti verotyytymättömyydestä. Veronkannon yksityistämiseen liittynyt Hurtta-ongelma säilyy muistissa $\mathrm{mm}$. siihen liittyvän taiteen vuoksi. Uudempiakin veroprotesteja Suomessa on ollut myös itsenäisyyden aikana, vaikka niistä ei vielä ole julkaistu kattavaa tutkimusta. Historiantutkimuksen lisäksi tarvitaan oikeustieteellistä tutkimusta siitä, milloin nämä protestit ovat laillisia ja milloin laittomia, sekä siitä, millaisia rangaistuksia ja muita seurauksia laittomiin veroprotesteihin ja niihin yllyttämiseen voi liittyä.

Maailman onnellisuusraportin mukaan suomalaiset ovat nykyisin maailman onnellisin kansa. Listan kärjessä ovat Suomi, Islanti, Tanska, Sveitsi, Hollanti, Ruotsi, Saksa, Norja, Uusi-Seelanti ja Itävalta. Veroasteemmekin on maailman korkeimpia. Verotaiteen valtavirtana kuitenkin pysynee protestointi, eikä verokarhu tule saamaan taiteessa rakastetun roolia. ${ }^{168}$ Tuomari Nurmion laulussa "Maailman onnellisin kansa" (2021) ei mainita sanaakaan verotuksesta.

168 Suomessa toimii Veronmaksajain Keskusliiton lisäksi Iloiset Veronmaksajat ry, jonka jäsenmäärä tosin on erittäin paljon pienempi. 


\section{Liite}

Tekijänoikeuksien yksinomaisen käyttöoikeuden luovuttaminen määräajaksi musiikintekijän yhtiölle

Antopäivä 28.9.2018, Diaarinumero A120/200/2018

Voimassaolo 28.9.2018 - Toistaiseksi

Valtuutussäännös Laki Verohallinnosta (503/2010) $2 \$ 2$ mom.

Tässä ohjeessa käsitellään tekijänoikeuksien käyvän arvon määrittämistä ja verotusta, kun musiikintekijä myöntää määräajaksi yksinomaisen käyttöoikeuden tekijänoikeuden yhteishallinnoinnista annetun lain (1494/2016, YHL) soveltamisalaan kuuluviin oikeuksiin ja korvauksiin omistamalleen osakeyhtiölle. Ohje ei koske muiden kuin edellä mainitun lain soveltamisalaan kuuluvien tekijänoikeuksien luovuttamista musiikintekijän yhtiölle.

\section{Johdanto}

\subsection{Taustaa}

Opetus- ja kulttuuriministeriö, työ- ja elinkeinoministeriö ja sosiaali- ja terveysministeriö asettivat 13.12.2016 työryhmän tekemään ehdotuksia luovien alojen vahvistamiseksi Suomessa.

Työryhmän 12.4.2017 päivätyssä julkaisussa (Opetus- ja kulttuuriministeriön julkaisuja 2017:18) asetettiin tavoitteeksi, että luovilla aloilla, esimerkiksi musiikin alalla, on oltava mahdollisuus toimia elinkeinonharjoittajana samoin edellytyksin kuin muissakin elinkeinoissa. Tämän tavoitteen saavuttamiseksi Teosto ja musiikin oikeuden 
haltioiden etujärjestöt selvittävät yhdessä valtiovarainministeriön ja tarvittaessa Verohallinnon kanssa edellytyksiä, jolla tekijänoikeudet voidaan siirtää tekijän yritykselle sekä siitä aiheutuvia veroseuraamuksia. Julkaisussa esitettiin myös, että Verohallinto laatii ohjeet tekijänoikeuksien siirtämiseen liittyvistä kysymyksistä tilanteessa, jossa tekijä luovuttaa tekijänoikeutensa omistamalleen yritystoimintaa harjoittavalle yritykselle.

Myös Sipilän hallituksen 28.4.2017 olleen puoliväliriihen kirjausten mukaan luovien alojen tekijänoikeuksien luovuttamiseen ja niiden arvostamiseen liittyvät verotuskäytännöt yhtenäistettäisiin, jolloin tekijänoikeudet ja niistä syntyvä tulo olisi mahdollista siirtää yhtiölle.

Yhtiön käyttäminen on usein edellytyksenä kansainvälisissä liikesuhteissa ja perusteltua esimerkiksi asiakkuuksien hoitamisen, laskutuksen, toiminnassa tarvittavan kaluston hankinnan ja hallinnoinnin kannalta sekä muiden immateriaalioikeuksien hallinnoimiseksi.

\subsection{Yleistä tekijänoikeuksien verotuksesta}

Tekijänoikeudet (oikeus kirjoitukseen, sävellykseen ja sanoitukseen, valokuvaan, tietokoneohjelmaan tai muuhun teokseen) ovat immateriaalioikeuksia. Tekijälle kertyy teoksensa taloudellisesta hyödyntämisestä tekijänoikeustuloa, joka on veronalaista käyttökorvausta. Tekijä saa oikeudestaan korvausta, kun hän luovuttaa oikeutensa joko kokonaan tai osittain tai joku muu käyttää suojattua teosta. Tekijä voi myös sopimuksella luopua kokonaan tai määräajaksi tekijänoikeudestaan.

Tekijänoikeuden luovuttamisesta saatu korvaus on luovuttajan veronalaista tuloa. Tuloverolain (TVL) 52 \$:n mukaan verovelvollisen saama korvaus patentista, tekijänoikeudesta tai muusta niihin verrattavasta oikeudesta on veronalaista pääomatuloa, jos oikeus on saatu perintönä tai testamentilla taikka hankittu vastiketta vastaan. Muutoin korvaus on ansiotuloa. Tekijänoikeuksien verotuksesta on kerrottu enemmän Verohallinnon ohjeessa Aineettomista oikeuksista saatavien tulojen verotus.

Tekijänoikeuksien luovutuksesta tai siirtämisestä toiselle verovelvolliselle ei ole tuloverolaissa erityissäännöksiä. Oikeuskäytännön (KHO 24.11.2000 taltio 3033 ja KHO 14.2.2003 taltio 342) mukaan tekijänoikeuteen liittyvät taloudelliset oikeudet voidaan siirtää esimerkiksi 
osakeyhtiöön. Tämä kuitenkin edellyttää, että oikeuksien siirrosta on tehty nimenomainen sopimus luovuttajan ja yhtiön välillä ja oikeuksien siirrosta maksetaan käypä korvaus. Tekijänoikeudet on siten arvostettava siirtohetkellä niiden käypään arvoon. Verotuskäytännössä on ongelmana ollut nimenomaan erilaisten tekijänoikeuksien käyvän arvon määritys.

\subsection{Ohjeen soveltamisala}

Tässä ohjeessa käsitellään tekijänoikeuksien käyvän arvon määrittämistä ja verotusta, kun musiikintekijä (säveltäjä, sanoittaja ja sovittaja) myöntää sopimuksen perusteella määräajaksi yksinomaisen käyttöoikeuden (lisenssin) YHL:n soveltamisalaan kuuluviin tekijänoikeuksiin ja korvauksiin omistamalleen osakeyhtiölle. Tällaista sopimusta on käsitelty jäljempänä kohdassa 2. Ohjeessa esitettyjä verotusperiaatteita sovelletaan ainoastaan tällaiseen sopimusmalliin ja siihen liittyviin sopimuksiin.

Tekijä voi tässä ohjeessa käsitellyn sopimusjärjestelyn ulkopuolella siirtää yhtiölle muita haluamiaan oikeuksia, jotka eivät kuulu YHL:n soveltamisalan piiriin. Tässä ohjeessa ei käsitellä näiden muiden oikeuksien tai kustannussopimusten siirtämistä musiikintekijän osakeyhtiölle eikä myöskään niistä musiikintekijälle ja osakeyhtiölle aiheutuvia veroseuraamuksia. Muiden oikeuksien ja sopimusten käypä arvo määritetään aina niistä saatujen ja saatavien tosiasiatietojen perusteella käyttäen kyseiseen tapaukseen parhaiten soveltuvaa arvonmäärittämismenetelmää.

\section{Tekijänoikeusjärjestön kanssa solmittava sopimus}

\subsection{Yleistä sopimusjärjestelystä}

Sopimusjärjestelyn lähtökohtana on tekijänoikeuksien yksinomaisen käyttöoikeuden luovuttaminen musiikintekijän osakeyhtiölle niin, että tekijä voi edelleen pysyä tekijänoikeusjärjestönsä jäsenenä tai oikeudenhaltija-asiakkaana. Koska kokonaisjärjestelyn erityisenä 
tarkoituksena on tekijän elinkeinotoiminnan edellytysten parantaminen, järjestelyn soveltamisala ja -ehdot on rajattu vastaamaan tätä tavoitetta.

Yllä mainittujen oikeuksien siirtäminen yhtiölle on vapaaehtoista ja sen täytyy perustua yhteishallinnointiorganisaation (jäljempänä tekijänoikeusjärjestö), oikeudenhaltijan (jäljempänä musiikintekijä) ja oikeudenhaltijan omistaman yhtiön väliseen määräaikaiseen sopimukseen (jäljempänä kokonaisjärjestely). Sopimuksesta on kerrottu lisää täällä.

Musiikintekijä siirtää kokonaisjärjestelyllä yhtiölleen ainoastaan sellaiset tekijänoikeuslain 2 §:ään perustuvat määräämisoikeudet, joiden laatu ja laajuus vastaavat YHL 5 \$:n mukaista musiikintekijän antamaa valtuutusta tekijänoikeusjärjestölle. Sopimus koskee siten ainoastaan YHL:n soveltamisalaan kuuluvia oikeuksia ja korvauksia.

Käytännössä yllä mainituissa oikeuksissa on kyse tekijänoikeusjärjestön sen hallinnointiin annettujen, jo olemassa olevien ja sopimuskauden aikana syntyneiden uusien oikeuksien perusteella musiikintekijälle tilittämistä tekijänoikeuskorvauksista.

\subsection{Sopimusjärjestelyn osapuolet ja siihen sisältyvät oikeustoimet}

Kokonaisjärjestelyssä on oltava osapuolina YHL:ssa tarkoitettu yhteishallinnointiorganisaatio (tekijänoikeusjärjestö, YHL $4 \$ 1$ kohta), oikeudenhaltija (musiikintekijä, YHL $4 \$ 4$ kohta) ja osakeyhtiölaissa tarkoitettu musiikintekijän omistama yksityinen osakeyhtiö (OYL 1 luku 1 §). Musiikintekijän omistamalla osakeyhtiöllä tarkoitetaan tässä ohjeessa musiikintekijän yksin tai yhdessä muiden musiikintekijöiden kanssa omistamaa osakeyhtiötä.

Kokonaisjärjestelyyn kuuluvat seuraavat oikeustoimet:

- oikeudenhaltijan tekijänoikeusjärjestölle antaman valtuutuksen (YHL 5 \$) osittainen ja määräaikainen peruuttaminen (YHL 8 \$) eli määräämisoikeuden palauttaminen;

- valtuutuksen peruuttamisen piiriin kuuluvien oikeuksien määräaikainen yksinomaisen käyttöoikeuden luovuttaminen osakeyhtiölle, jonka kaikki osakkeet kuuluvat valtuutuksensa osittain 
peruuttaneelle musiikintekijälle, tai jonka kaikki osakkeet kuuluvat valtuutuksensa osittain peruuttaneelle musiikintekijälle sekä samalle tekijänoikeusjärjestölle valtuutuksen antaneille muille musiikintekijöille;

- osakeyhtiön antama toimeksianto samalle tekijänoikeusjärjestölle hallinnoida valtuutuksen osittaisen peruuttamisen piiriin kuuluvia osakeyhtiölle myönnettyjä oikeuksia yhtiön lukuun.

Yllä mainittu valtuutuksen peruuttaminen ei ole varallisuuden luovuttamista, koska tekijänoikeusjärjestö ei alkuperäisen valtuutuksen perusteella ole siirronsaaja. Tuotto-oikeus kuuluu valtuutuksen kestäessä edelleen oikeudenhaltijalle (YHL 22 \$). Osakeyhtiön antama toimeksianto hallinnoida peruuttamisen piiriin kuuluvia oikeuksia ei myöskään ole varallisuuden luovuttamista, koska tekijänoikeusjärjestölle ei toimeksiannon perusteella synny siirronsaajan asemaa eikä sille siirry tuotto-oikeutta.

Sen sijaan yllä mainittu oikeuksien yksinomaisen käyttöoikeuden luovuttaminen osakeyhtiölle on varallisuusarvoisen aineettoman oikeuden siirtämistä, koska oikeuksien määräämisoikeuden lisäksi myös oikeus niiden tuottoon siirtyy yhtiölle.

Kokonaisjärjestely on luonteeltaan väliaikainen, koska osapuolten tarkoituksena ei ole lopullisesti peruuttaa musiikintekijän valtuutusta tekijänoikeusjärjestölle. Järjestely mahdollistaa valtuutuksen jatkumisen siinä vaiheessa, kun yhtiön käyttämiselle musiikintekijän elinkeinotoiminnassa ei enää ole tarvetta tai perusteita. Näistä syistä kokonaisjärjestely on aina määräaikainen ja kestoltaan lähtökohtaisesti vähintään yksi ja enintään viisi vuotta. Järjestely olisi uudistettavissa uudeksi määräajaksi kaikkien osapuolten yhteisellä sopimuksella.

Sopimus päättyy kesken määräajan musiikintekijän kuoleman vuoksi. Sopimus voi päättyä ennen määräajan päättymistä myös, jos musiikintekijän osakeyhtiö tulee maksukyvyttömäksi tai hakeutuu yrityssaneeraukseen tai selvitystilaan kokonaisjärjestelyn aikana sekä, jos musiikintekijän osakeyhtiö purkautuu konkurssin seurauksena. Samoin sopimus päättyy kesken sopimuskauden, jos osakeyhtiön osakekanta tai osakkeisiin perustuva määräysvalta osaksikaan siirtyy muille kuin sopimuksen allekirjoittamishetkellä yhtiön omistajana oleville tahoille. 


\section{$3 \quad$ Yleistä tekijänoikeuksien arvostamisesta}

\subsection{Verohallinnon varojen arvostamista koskeva ohjeistus}

Verohallinnon ohjeessa Varojen arvostaminen perintö- ja lahjaverotuksessa on kohdassa 1.2.2 käsitelty yleisesti omaisuuden arvonmääritysmenetelmiä. Ohjeen mukaan kohteen käypä arvo määritetään aina siitä saatujen ja saatavien tosiasiatietojen perusteella käyttäen kyseiseen tapaukseen parhaiten soveltuvaa arvonmäärittämismenetelmää. Valitun menetelmän tulee ottaa huomioon kohteen mahdolliset erityispiirteet.

Omaisuuden toteutuneiden tai vertailuluovutuksissa käytettyjen luovutushintatietojen puuttuessa kohteen käypä arvo määritetään laskelmilla, jotka perustuvat tosiasiatietoihin arvonmäärittämisen kohteesta. Menetelminä voidaan käyttää esimerkiksi tuottoarvo- ja kustannusarvolaskelmia. Lähtökohtaisesti omaisuuden arvoa määritettäessä sovelletaan ohjeessa esitettyjä arvostamismenetelmiä, jos ei ole perusteltua syytä niistä poikkeavan, käypään arvoon johtavan, metodin käyttämiseksi.

\subsection{Tekijänoikeuksien arvostamisperiaatteet}

Tekijänoikeuksien arvostamisesta tuloverotuksessa ei ole erillistä Verohallinnon ohjetta. Yllä mainitussa ohjeessa esitettyjä periaatteita on sovellettu soveltuvin osin myös tuloverotuksessa tällaisen omaisuuden arvonmäärityksessä. Kun samanlaisten oikeuksien vertailuluovutuksia ei yleensä ole, eikä muutakaan perusteltua käyvän arvon osoittavaa arvostamismenetelmää ole käytettävissä, oikeudet arvostetaan tuottoarvomenetelmää käyttäen.

Verotuskäytännössä lasketaan yksityishenkilöiden omistamien tekijänoikeuksien siirtotilanteissa niiden käypä arvo lähtökohtaisesti Verohallinnon yllämainitun ohjeen kohdassa 1.2.3. kerrotulla 
tuottoarvomenetelmällä. Tuottoarvomenetelmä tarkoittaa menetelmää, jolla kohteen arvo (todennäköinen luovutushinta) määritetään kohteesta käyttöaikana tulevaisuudessa todennäköisesti saatavien vuosituottojen pääomitettuna nykyarvona.

Esimerkiksi kirjailijoilla on tavallisimmin toisena sopijapuolena kustantaja, joka maksaa kirjan kirjoittajalle korvausta. Tämä arvo lasketaan pääomittamalla oikeuden todennäköinen tuotto. Pääomituksessa otetaan tapauskohtaisen selvityksen pohjalta huomioon oikeuden todennäköinen tuotto, sen kestoaika ja tuoton epävarmuuden huomioon ottava pääomituskorkokanta. Vuotuinen nettotuotto joudutaan muun tiedon puuttuessa usein määrittämään historiatietojen perusteella.

Tässä ohjeessa kuvattuun musiikintekijöiden tekijänoikeuksien yksinomaisen käyttöoikeuksien määräaikaiseen luovuttamiseen osakeyhtiölle liittyy sellaisia erityispiirteitä ja -ehtoja, että tällaisissa tilanteissa sovelletaan verotuksessa jäljempänä esitettyjä periaatteita. Ohjeen linjauksia ei siis voida soveltaa mahdollisten muiden oikeuksien siirtämiseen musiikintekijän osakeyhtiölle.

\section{Määräajaksi luovutetun yksinomaisen käyttöoikeuden arvostaminen}

\subsection{Yleistä}

Musiikintekijä voi luovuttaa tekijänoikeusjärjestön kanssa solmittavalla sopimuksella tekijänoikeuksien yksinomaisen käyttöoikeuden omistamalleen osakeyhtiölle määräajaksi, kuitenkin vähintään yhdeksi ja enintään viideksi vuodeksi.

Sen lisäksi, että oikeuksien siirron yhtiölle on perustuttava edellä kohdassa 2 käsiteltyyn sopimukseen, yhtiön oikeuksista maksaman korvauksen (lisenssimaksu) on vastattava niiden käypää arvoa. Yhtiön maksama käypä korvaus määräytyy lähtökohtaisesti sen perusteella, mikä oikeuksien tuottoarvo olisi musiikintekijälle siinä tilanteessa, että hän olisi itse valtuuttanut tekijänoikeusjärjestön hallinnoimaan oikeuksiaan YHL 5 \$:n mukaisesti. Tämä vastaa tekijänoikeusjärjestön 
Liite

musiikintekijälle kulloinkin maksamien tekijänoikeuskorvausten arvoa.

Tekijänoikeuskorvausten kertymiselle ovat tyypillisiä kausikohtaiset erot, jotka johtuvat mm. teosten markkinasuosion vaihteluista, menestyvien teosten kerryttämistä tuottopiikeistä ja sopimuskauden aikana syntyvistä uusista teoksista sekä siitä, onko kyseessä jo pitkään toiminut vai vasta uraansa aloitteleva musiikintekijä. Tekijänoikeustuottojen kertymistä on siksi vaikeaa ennustaa luotettavasti.

Seuraavassa on esitetty perusperiaatteet tekijänoikeuskorvausten käyvän arvon laskemisesta erilaisissa tilanteissa.

\subsection{Korvauksen käyvän arvon laskemisperiaatteet}

\subsubsection{Käyvän arvon laskemisen perusperiaatteet}

Yhtiön käyttöoikeuksista musiikintekijälle maksaman käyvän korvauksen (lisenssimaksun) määrä lasketaan seuraavasti:

- lasketaan tekijänoikeusjärjestön musiikintekijälle kalenterivuosittain tilittämien korvausten keskiarvo sopimuskauden alkua lähinnä edeltäneiltä 5 kalenterivuodelta tai näiden puuttuessa 1-4 kalenterivuodelta, joilta korvauksia on tilitetty (keskimääräinen vuosituotto);

- lasketaan 15 \%:n mukaisen pääomituskorkokannan ja oikeuksien sopimuskauden määräajan (1-5 vuotta) pituuden perusteella määräytyvä pääomituskerroin;

- lasketaan koko sopimusajalle keskimääräisen vuosituoton ja pääomituskertoimen tulona määräytyvä korvaus (lisenssimaksu).

Yllä todettua tekijänoikeusjärjestön tekijälle tilittämien korvausten keskimääräistä vuosituottoa laskettaessa tarkoitetaan kunkin vuoden korvauksilla musiikintekijän saamaa nettokorvausta. Nettokorvaus saadaan vähentämällä tekijänoikeusjärjestön tilittämästä kunkin vuoden korvauksesta osakeyhtiön laskennallinen tuloverovelka (tällä hetkellä 20 \%). Jäljempänä olevissa esimerkeissä tekijänoikeuskorvausten keskiarvolla tarkoitetaan laskennallisella tuloverovelalla vähennettyä 
määrää. Musiikintekijän aikanaan saamistaan tekijänoikeustuloista maksamia todellisia tai laskennallisia veroja ei oteta huomioon nettokorvausta laskettaessa.

Pääomituskorkokantana laskennassa käytetään aina kaavamaisesti $15 \%$. Edellä mainittu $15 \%$ :n mukaisen pääomituskorkokannan ja sopimuskauden määräajan pituuden perusteella määräytyvä pääomituskerroin on esitetty vuosittain alla olevassa taulukossa:

Pääomituskerroin

\begin{tabular}{|c|c|}
\hline Vuosien lukumäärä & Pääomituskerroin \\
\hline 1 & 0,8696 \\
\hline 2 & 1,6257 \\
\hline 3 & 2,2832 \\
\hline 4 & 2,8550 \\
\hline 5 & 3,3522 \\
\hline
\end{tabular}

Tekijänoikeuksien arvioitu lisenssimaksu koko sopimusajalle saadaan laskemalla keskimääräisen vuosituoton ja pääomituskertoimen tulona määräytyvä korvaus. Tekijänoikeuksien kunkin vuoden käypänä korvauksena pidetään suhteellista osuutta koko sopimusajalle lasketusta lisenssimaksusta (esimerkiksi neljän vuoden määräaikaisessa sopimuksessa $25 \%$ lisenssimaksusta).

Esimerkki 1: Neljän vuoden sopimus

Make luovuttaa tekijänoikeuksien yksinomaisen käyttöoikeuden omistamalleen osakeyhtiölle 1.1.2018 neljän vuoden määräajaksi. Maken sopimusta edeltävien viiden kalenterivuoden aikana saamien tekijänoikeuskorvausten keskiarvo on 18.000 euroa. 15 \%:n mukaisen pääomituskorkokannan ja oikeuksien sopimuskauden määräajan (4 vuotta) pituuden perusteella määräytyvä pääomituskerroin on tässä tilanteessa 2,8550. Koko sopimusajalle keskimääräisen vuosituoton ja pääomituskertoimen tulona määräytyvä tekijänoikeuksien käypä arvo on 51.390 euroa $(=18.000$ euroa $\mathrm{x} 2,8550)$. Tekijänoikeuksien kunkin vuoden lisenssimaksu sopimuskauden aikana on siten $12.847,50$ euroa $(=51.390$ euroa / 4).

Jos sopimus alkaa muulloin kuin kalenterivuoden alussa, tekijänoikeuksien sopimuskauden kullekin vuodelle kohdistuvaksi lisenssimaksuksi 
katsotaan kyseiselle verovuodelle kohdistuva osa koko sopimusajalle lasketusta lisenssimaksusta.

Esimerkki 2: Tammikuun alussa 2018 alkavan viiden vuoden määräaikaisessa sopimuksessa $1 / 5$ osa lisenssimaksusta verotetaan musiikintekijän vuoden 2018 ansiotulona.

Esimerkki 3: Elokuun alussa 2018 alkavan kolmen vuoden määräaikaisessa sopimuksessa 7/36 osaa lisenssimaksusta verotetaan musiikintekijän vuoden 2021 ansiotulona.

\subsubsection{Tekijänoikeuskorvauksia jo aikaisemmin saanut musiikintekijä}

Kausivaihteluiden tasaamiseksi otetaan oikeuksien käyvän arvon perusteeksi tekijänoikeusjärjestön musiikintekijälle aiemmin vuosittain maksamat tekijänoikeuskorvaukset aina viideltä oikeuksien siirtoa lähinnä edeltäneeltä täydelta kalenterivuodelta riippumatta tekijänoikeuksien luovuttamista koskevan määräaikaisen sopimuksen pituudesta (katso yllä esimerkki 1).

Jos tekijänoikeuskorvauksia jo saaneelle musiikintekijälle ei ole ennen oikeuksien siirtoa ehditty maksaa tekijänoikeuksia viiden täyden kalenterivuoden aikana, otetaan käyvän arvon perusteeksi hänelle aiemmin sopimusta edeltäneinä täysinä kalenterivuosina (1-4) maksetut tekijänoikeuskorvaukset riippumatta tekijänoikeuksien luovuttamista koskevan määräaikaisen sopimuksen pituudesta.

Esimerkki 4: Tekijänoikeuskorvauksia kahdelta vuodelta, neljän vuoden sopimus

Peran sopimusta edeltävien kahden kalenterivuoden aikana saamien tekijänoikeuskorvausten keskiarvo on 20.000 euroa. 15 \%:n mukaisen pääomituskorkokannan ja oikeuksien sopimuskauden määräajan (4 vuotta) pituuden perusteella määräytyvä pääomituskerroin on 2,8550. Koko sopimusajalle keskimääräisen vuosituoton ja pääomituskertoimen tulona määräytyvä tekijänoikeuksien käypä arvo on 57.100 euroa $(=20.000$ euroa x 2,8550). Tekijänoikeuksien kunkin vuoden lisenssimaksu sopimuskauden aikana on siten 14.275 euroa (= 57.100 euroa / 4). 
Esimerkki 5: Tekijänoikeuskorvauksia neljältä vuodelta, joista vain kolmena korvauksia on maksettu täydeltä kalenterivuodelta, viiden vuoden sopimus

Pera on liittynyt tekijänoikeusjärjestön jäseneksi 1.5. 2014. Hän on saanut tekijänoikeuskorvauksia neljän edeltävän vuoden aikana seuraavasti:

Esimerkki tekijänoikeuskorvauksista

\begin{tabular}{|c|c|}
\hline Ajanjakso & Ajanjaksona saadut tekijänoikeuskorvaukset \\
\hline $1.5 .-31.12 .2014$ & 5.000 euroa \\
\hline $1.1 .-31.12 .2015$ & 9.000 euroa \\
\hline $1.1 .-31.12 .2016$ & 8.500 euroa \\
\hline $1.1 .-31.12 .2017$ & 13.100 euroa \\
\hline
\end{tabular}

Pera luovuttaa tekijänoikeuksien yksinomaisen käyttöoikeuden omistamalleen osakeyhtiölle 1.1.2018 viiden vuoden määräajaksi. Hänen sopimusta edeltävien kolmen täyden kalenterivuoden aikana saamien tekijänoikeuskorvausten keskiarvo on 10.200 euroa (= 30.600 euroa ( 3). $15 \%$ :n mukaisen pääomituskorkokannan ja oikeuksien sopimuskauden määräajan (5 vuotta) pituuden perusteella määräytyvä pääomituskerroin on 3,3522. Koko sopimusajalle keskimääräisen vuosituoton ja pääomituskertoimen tulona määräytyvä tekijänoikeuksien käypä arvo on 34.192,44 euroa (= 10.200 euroa x 3,3522). Tekijänoikeuksien kunkin vuoden lisenssimaksu sopimuskauden aikana on siten 6.838,49 euroa $(=34.192,44$ euroa / 5).

\subsubsection{Uraansa aloitteleva musiikintekijä}

Jos uraansa aloittelevalle musiikintekijälle ei ole ennen tekijänoikeuksien luovuttamista maksettu lainkaan tekijänoikeuskorvauksia, joudutaan ensimmäisen vuoden korvausten määrä arvioimaan. Laskentajakso ja sopimusaika voi tällaisessa tapauksessa olla ainoastaan vuosi.

Jos musiikintekijä ei pysty esittämään ensimmäisen vuoden korvausten määrästä muuta luotettavaa arviota, pidetään korvausten arvioituna määränä kulloinkin sopimuksentekohetkellä voimassa olevaa tekijänoikeusjärjestön tätä tarkoitusta varten laskemaa tekijänoikeuksien mediaanituloa. Tekijänoikeusjärjestö tarkistaa ja julkaisee 
internet-sivuillaan vuosittain tässä tarkoitetun mediaanitulon määrän. Vuodelle 2018 laskettu mediaanitulo on 1.200 euroa.

Esimerkki 6: Aloittava musiikintekijä, vuoden sopimus

Aki ei pysty arvioimaan ensimmäisenä vuonna mahdollisesti saamiensa tekijänoikeuskorvausten määrää. Tästä syystä pidetään korvausten arvioituna määränä yllä mainittua 1.200 euron mediaanituloa. $15 \%$ :n mukaisen pääomituskorkokannan ja oikeuksien sopimuskauden määräajan (vuosi) pituuden perusteella määräytyvä pääomituskerroin on 0,8696 . Vuoden sopimusajalle keskimääräisen vuosituoton ja pääomituskertoimen tulona määräytyvä tekijänoikeuksien käypä arvo (lisenssimaksu) on $1.043,52$ euroa $(=1.200$ euroa x 0,8696$)$.

Ensimmäisen sopimusvuoden jälkeen musiikintekijä voi tehdä uuden sopimuksen 1-3 vuodelle. Uuden sopimuksen oikeuksien käyvän arvon perusteeksi otetaan ensimmäisenä vuonna maksetut tekijänoikeuskorvaukset. Jos uusi sopimus tehdään vuotta pitemmälle ajalle, tätä määrää pidetään sopimusajan keskimääräisenä vuosituottona.

Esimerkki 7: Aloittava musiikintekijä, uusi kahden vuoden sopimus

Aki solmii heti ensimmäisen sopimuksen päättymisen jälkeen kahden vuoden sopimuksen. Yhtiö sai ensimmäisenä sopimusvuonna tekijänoikeuskorvauksia 4.000 euroa. Tätä määrää pidetään uuden sopimusajan keskimääräisenä vuosituottona (katso jäljempänä kohta 6.3). 15 \%:n mukaisen pääomituskorkokannan ja oikeuksien sopimuskauden määräajan (2 vuotta) pituuden perusteella määräytyvä pääomituskerroin on 1,6257. Koko sopimusajalle keskimääräisen vuosituoton ja pääomituskertoimen tulona määräytyvä tekijänoikeuksien käypä arvo (lisenssimaksu) on $6.502,80$ euroa $(=4.000$ euroa x 1,6257). Tekijänoikeuksien kunkin vuoden lisenssimaksu uuden sopimuskauden aikana on siten 3.251,40 euroa $(=6.502,80$ euroa / 2$)$.

Jos uraansa aloitteleva musiikintekijä haluaa tehdä ensimmäisen sopimuksen päättymisen jälkeen tekemänsä $1-3$ vuoden sopimuksen määräajan päättyessä taas uuden sopimuksen, voidaan tämä sopimus tehdä 1-5 vuodeksi. Uuden sopimuskauden käyttöoikeuksien keskimääräisenä vuosituottona käytetään tällaisessa tapauksessa jo päättyneiden sopimuskausien (1 ja 1-3 vuotta) aikana maksettujen tekijänoikeuskorvausten keskiarvoa.

Esimerkki 8: Aloittava musiikintekijä, alkuun vuoden sopimus, sitten uusi kahden vuoden sopimus, jonka jälkeen uusi viiden vuoden sopimus Aki solmii heti toisen sopimuksen päättymisen jälkeen uuden viiden vuoden sopimuksen. Yhtiö sai ensimmäisen vuoden sopimuksen aikana 
tekijänoikeuskorvauksia 4.000 euroa (katso jäljempänä kohta 6.3). Sitä seuranneen kahden vuoden sopimuskauden aikana yhtiö sai tekijänoikeuskorvauksia yhteensä 26.000 euroa. Uuden viiden vuoden sopimusajan keskimääräisenä vuosituottona pidetään kahden edellisen sopimuskauden aikana saatujen tekijänoikeustulojen keskiarvoa eli 10.000 euroa $(=(4.000$ + 26.000) / 3). $15 \%$ :n mukaisen pääomituskorkokannan ja oikeuksien sopimuskauden määräajan ( 5 vuotta) pituuden perusteella määräytyvä pääomituskerroin on 3,3522. Koko sopimusajalle keskimääräisen vuosituoton ja pääomituskertoimen tulona määräytyvä tekijänoikeuksien käypä arvo (lisenssimaksu) on 33.522 euroa (= 10.000 euroa x 3,3522). Tekijänoikeuksien kunkin vuoden lisenssimaksu uuden viiden vuoden sopimuskauden aikana on siten $6.704,40$ euroa $(=33.522$ euroa / 5$)$.

\section{Tekijänoikeuksista maksettavan korvauksen verokohtelu}

\subsection{Musiikintekijän verotus}

Yhtiön musiikintekijälle maksamaa tuloa (lisenssimaksua) verotetaan TVL 52 \$:n nojalla tekijän ansiotulona. Tekijän ansiotulona verotettavana tulona pidetään kullekin verovuodelle kohdistuvaa ja hänelle sopimuksen mukaan maksettavaa osaa koko sopimusajalle lasketusta lisenssimaksusta.

Esimerkki 9: Neljän vuoden sopimus, sopimus alkaa 1.6.

Kikka luovuttaa tekijänoikeuksien yksinomaisen käyttöoikeuden omistamalleen osakeyhtiölle 1.6.2018 neljän vuoden määräajaksi. Tekijänoikeuksien käypä arvo (lisenssimaksu) koko sopimusajalle on 51.390 euroa. Kikan yhtiöltään saamat ja hänen ansiotulonaan verotettavat lisenssimaksut kohdistuvat eri verovuosille seuraavasti:

Esimerkkitaulukko

\begin{tabular}{|l|l|}
\hline \multicolumn{1}{|c|}{ Ajanjakso } & \multicolumn{1}{c|}{ Ajanjaksona verotettava osa lisenssimaksusta } \\
\hline $1.6 .-31.12 .2018$ & $7.494,38$ euroa $(=51.390$ euroa $/ 4 \times 7 / 12)$ \\
\hline $1.1 .-31.12 .2019$ & $12.847,50$ euroa $(=51.390$ euroa $/ 4)$ \\
\hline $1.1 .-31.12 .2020$ & $12.847,50$ euroa $(=51.390$ euroa $/ 4)$ \\
\hline $1.1 .-31.12 .2021$ & $12.847,50$ euroa $(=51.390$ euroa $/ 4)$ \\
\hline $1.1 .-31.5 .2022$ & $5.353,13$ euroa $(=51.390$ euroa $/ 4 \times 5 / 12)$ \\
\hline
\end{tabular}


Tekijän ansiotulona verotettavasta korvauksesta voidaan tehdä verotuksessa normaalit ansiotulojen verotuksessa tehtävät vähennykset.

Tekijä voi nostaa omistamastaan osakeyhtiöstä sinne luovutetuista tekijänoikeuksista ja yhtiön harjoittamasta muusta elinkeinotoiminnasta kertynyttä tuloa itselleen esimerkiksi palkkana, osinkona tai osakaslainana. Hänen nostamaansa tuloa verotetaan kyseistä tuloa koskevien säännösten ja periaatteiden mukaan normaalisti.

Musiikintekijän kalenterivuonna ennen sopimuksen tekemistä tai sen päättymisen jälkeen (jos hän ei solmi heti uutta sopimusta) tekijänoikeusjärjestöltä saamat tekijänoikeuskorvaukset verotetaan normaalisti ansiotulona TVL 52 \$:n mukaisesti.

Esimerkki 10: Kikka ei halua tehdä uutta sopimusta yllä olevassa esimerkissä mainitun sopimuksen päätyttyä. Hän on saanut tekijänoikeustuloja ennen sopimusta vuonna 2018 (1.1.-31.5.2018) yhteensä 4.000 euroa. Nämä tulot on verotettu hänen vuonna 2018 saaminaan tekijänoikeustuloina. Kikka saa sopimuksen päättymisen jälkeen vuonna 2022 (1.6.-31.12.2022) tekijänoikeustuloja yhteensä 6.000 euroa. Nämä tulot verotetaan hänen vuonna 2022 saaminaan tekijänoikeustuloina.

\subsection{Yhtiön verotus}

Elinkeinotulon verottamisesta annetun lain (EVL) 4 \$:n mukaan yhtiön veronalaisia elinkeinotuloja ovat elinkeinotoiminnassa rahana tai rahanarvoisena etuutena saadut tulot. Osakeyhtiön saamat tekijänoikeuskorvaukset ovat siten yhtiön elinkeinotoiminnan tuloa, jos ne liittyvät yhtiön harjoittamaan elinkeinotoimintaan. Yhtiön elinkeinotoiminnan tulona pidetään kullekin verovuodelle kohdistuvaa osaa tekijänoikeusjärjestön sille tilittämistä tekijänoikeuskorvauksista.

EVL 7 \$:n mukaan vähennyskelpoisia ovat elinkeinotoiminnassa tulon hankkimisesta tai säilyttämisestä johtuneet menot ja menetykset. EVL 22 §:n mukaan meno on sen verovuoden kulua, jonka aikana sen suorittamisvelvollisuus on syntynyt. Elinkeinotoimintaa harjoittava musiikintekijän omistama osakeyhtiö voi vähentää omassa verotuksessaan tekijänoikeuksista musiikintekijälle sopimuksen mukaan kullekin vuodelle kohdistuvan lisenssimaksun.

Jos yhtiö ainoastaan saa tekijänoikeusjärjestön tilittämät korvaukset ja maksaa ne edelleen musiikintekijälle esimerkiksi lisenssimaksuina 
tai osinkona ilman, että yhtiö harjoittaa muuta toimintaa, verotetaan yhtiötä lähtökohtaisesti TVL:n mukaan. Yhtiön saamien tekijänoikeuskorvausten verottamisessa ja yhtiön maksamien lisenssimaksujen vähentämisessä noudatetaan myös tällöin yllä esitettyjä periaatteita. Osakeyhtiön verotuksesta on kerrottu enemmän esimerkiksi ohjeessa Tuloverotus - osakeyhtiö ja osuuskunta.

Yhtiön on toimitettava ennakkoperintälain (EPL) 25 \$:n 1 momentin 2) kohdan mukaan ennakonpidätys musiikintekijälle vuosittain maksamistaan lisenssimaksuista, jos musiikintekijää ei ole merkitty ennakkoperintärekisteriin. Ennakonpidätys on toimitettava ennakkoperintäasetuksen (EPA) mukaan tekijän verokorttiin merkityn ennakonpidätysprosentin mukaisesti (EPA 10 \$). Jos musiikintekijä ei toimita maksajalle verokorttia, ennakonpidätys on toimitettava 60 prosentin suuruisena (EPA $3 \$$ ).

\section{Sopimuksen päättyminen ja jatkaminen}

\subsection{Sopimuksen päättyminen sopimuskauden kuluttua umpeen}

Sopimuksen määräajan päätyttyä palautuvat sopimuksen kohteena olevat musiikintekijän tekijänoikeudet osakeyhtiöltä tekijänoikeusjärjestön hallinnoitaviksi. Tällaisessa tilanteessa oikeuksien palauttaminen ei aiheuta veroseuraamuksia musiikintekijälle eikä hänen omistamalleen osakeyhtiölle. Sopimuksen päättymisen jälkeen tekijänoikeusjärjestöltä saadut tekijänoikeustulot verotetaan normaalisti musiikintekijän ansiotulona TVL 52 \$:n mukaisesti.

\subsection{Sopimuksen päättyminen ennen sopimuskauden umpeen kulumista}

Jos sopimus päättyy musiikintekijän kuoleman vuoksi ennen sopimuskauden umpeen kulumista, palautuvat sopimuksen kohteena olevat musiikintekijän tekijänoikeudet sopimuksen päättymishetkellä 
osakeyhtiöltä tekijänoikeusjärjestön hallinnoitaviksi musiikintekijän tai tämän oikeudenomistajien nimiin.

Sopimus voi päättyä ennen määräajan päättymistä myös, jos musiikintekijän osakeyhtiö tulee maksukyvyttömäksi tai hakeutuu yrityssaneeraukseen tai selvitystilaan kokonaisjärjestelyn aikana. Näissä tapauksissa järjestely päättyy riippuen päättymisen perusteesta joko silloin, kun yhtiön on todettu olevan konkurssilain (2004/120) 2 luvun 3 \$:n mukaisesti maksukyvytön, yhtiötä koskeva hakemus saneerausmenettelystä on jätetty käräjäoikeudelle tai yhtiö on asetettu selvitystilaan.

Jos musiikintekijän osakeyhtiö asetetaan kokonaisjärjestelyn aikana konkurssiin, musiikintekijällä on 30 päivän kuluessa saatuaan tästä tiedon oikeus lunastaa lisenssisopimuksen mukaiset oikeudet itselleen. Lunastushinnan määrää, ellei sitä sovita, tekijänoikeusjärjestön nimeämä toimialan tunteva puolueeton asiantuntija. Lunastushinnassa otetaan huomioon jäljellä oleva lisenssikausi sekä oikeuksien tuotto-odotus lisenssikautena. Musiikintekijän maksama lunastushinta on hänelle vähennyskelpoinen meno tulonhankkimiskuluna. Kokonaisjärjestely purkautuu musiikintekijän osakeyhtiön purkauduttua konkurssin seurauksena.

Samoin sopimus päättyy kesken sopimuskauden, jos osakeyhtiön osakekanta tai osakkeisiin perustuva määräysvalta osaksikaan siirtyy muille kuin sopimuksen allekirjoittamishetkellä yhtiön omistajana oleville tahoille. Tällöin järjestely päättyy osakkeiden tai osakkeisiin perustuvan määräysvallan siirtymishetkellä.

Yllä mainituissa tilanteissa oikeuksien palauttaminen ei sinällään aiheuta veroseuraamuksia musiikintekijälle, tämän oikeudenomistajille eikä hänen omistamalleen osakeyhtiölle. Kuitenkin, jos sopimus päättyy kalenterivuoden aikana, pidetään osakeyhtiön sopimuksen päättymisvuoden veronalaisena tulona kyseisenä kalenterivuonna maksettavista tekijänoikeuskorvauksista sitä osaa, joka kohdistuu sopimuksen voimassaoloajalle kyseisenä vuonna. Musiikintekijän saamana ansiotulona verotettavana lisenssimaksuna pidetään sitä osaa kyseisen vuoden lisenssimaksusta, joka kohdistuu sopimuksen voimassaoloajalle kyseisenä vuonna. Yhtiö voi vastaavasti vähentää verotuksessaan saman määrän kyseisen vuoden lisenssimaksuna. 
Esimerkki 11: Neljän vuoden sopimus, sopimus päättyy kolmantena vuonna musiikintekijän myydessä yhtiönsä osakkeet.

Anna on luovuttanut tekijänoikeuksien yksinomaisen käyttöoikeuden omistamalleen osakeyhtiölle 1.1.2018 neljän vuoden määräajaksi. Tekijänoikeuksien käypä arvo (lisenssimaksu) koko sopimusajalle on 60.000 euroa eli 15.000 euroa vuodessa. Anna myy yhtiönsä kaikki osakkeet Kikalle 31.8.2021 eli kesken sopimuskauden. Annan vuoden 2021 ansiotulona verotetaan hänelle sopimuksen voimassaoloaikaan 1.1.-31.8.2021 kohdistuva osuus kyseisen vuoden lisenssimaksusta eli 10.000 euroa (= $15.000 \times 8 / 12)$. Tämä määrä on myös yhtiön sopimuksen päättymisvuoden vähennyskelpoisen lisenssimaksun määrä.

\subsection{Sopimuksen uudistaminen}

Jos kokonaisjärjestelyn osapuolet haluavat uudistaa sopimuksen joko heti sen määräajan päättymisen jälkeen tai vasta myöhemmin, on tekijänoikeudet arvostettava uudestaan. Yhtiön tekijänoikeuksista tekijälle maksama käypä arvo (lisenssimaksu) lasketaan näissäkin tapauksissa edellä kohdassa 4.2 kuvatulla tavalla.

Sopimuksen uudistamisen yhteydessä pidetään käyvän arvon perusteena tekijänoikeusjärjestön yhtiölle ja musiikintekijälle aiemmin viideltä oikeuksien siirtoa edeltäneeltä kalenterivuodelta, tai näiden puuttuessa 1-4 kalenterivuodelta, maksamia tekijänoikeuskorvauksia.

Esimerkki 12: Sopimus tehty alkuun 3 vuodeksi, sopimus uudistetaan vasta 2 vuoden päästä uudeksi 3 vuoden sopimukseksi

Anna on luovuttanut tekijänoikeuksien yksinomaisen käyttöoikeuden omistamalleen osakeyhtiölle 1.1.2018 kolmen vuoden määräajaksi. Annan osakeyhtiö on saanut tekijänoikeuskorvauksia sopimusaikana 2018 - 2020 yhteensä 45.000 euroa. Anna ei uudista sopimusta sen päätyttyä 31.12.2020 ja hän saa sen jälkeen tekijänoikeuskorvauksia itselleen yhteensä 10.000 euroa vuonna 2021 ja 8.500 euroa vuonna 2022 . Anna päättää tehdä uuden kolmen vuoden sopimuksen tekijänoikeuksien yksinomaisen käyttöoikeuden luovuttamisesta yhtiölleen 1.1.2023.

Annan osakeyhtiön ensimmäisen kolmen vuoden sopimuksen aikana saamien tekijänoikeuskorvausten (45.000 euroa) ja Annan itse seuraavien kahden vuoden aikana saamien tekijänoikeuskorvausten (18.500 euroa) keskiarvo on 12.700 euroa (= 63.500 euroa / 5). 15 \%:n mukaisen pääomituskorkokannan ja oikeuksien sopimuskauden määräajan (3 vuotta) pituuden tulona määräytyvä pääomituskerroin on tässä tilanteessa 2,2832. 
Koko sopimusajalle keskimääräisen vuosituoton ja pääomituskertoimen tulona määräytyvä tekijänoikeuksien käypä arvo on 28.996,64 euroa $(=12.700$ euroa x 2,2832). Tekijänoikeuksien kunkin vuoden lisenssimaksu Annan uuden sopimuskauden aikana on siten 9.665,55 euroa (= 28.996,64 euroa / 3).

Tekijänoikeuksien uuden sopimuskauden kullekin vuodelle kohdistuvaksi käyväksi korvaukseksi katsotaan kyseiselle verovuodelle kohdistuva osa koko sopimusajalle lasketusta lisenssimaksusta (katso myös yllä esimerkki 9). 


\section{Tutkimuskirjallisuutta}

Ala-Lahti-Kataja, Anette Osakeyhtiön sivuuttaminen veronkiertosäännöstä soveltamalla - tulkintaympäristön kehitys, Verotus 2020 (väitöskirjaartikkeli)

Andersson, Edward Tuloverotus ja varallisuusverotus (1995)

Andersson, Edward - Gyllström, Katy Kuvataiteilijan verotuksesta (1982)

Andersson, Edward - Linnakangas, Esko - Frände, Joakim Tuloverotus (2016) Arajärvi, Pentti Taiteen vapaus (perusoikeutena), Tieteen termipankki

Burg, David F. A World History of Tax Rebellions - An Encyclopedia of Tax

Rebels, Revolts, and Riots from Antiquity to the Present (2004)

Halila, Heikki - Norros, Olli Urheiluoikeus (2017)

Helminen, Marjaana Kansainvälinen verotus (2016)

Juanto, Leila - Linnakangas, Esko Peliverot - vanhaa ja uutta, Verotus 2018 s. 606 ss.

Juanto, Leila - Punavaara, Anu - Saukko, Petri Arvonlisäverotus ja muu kulutusverotus (2018)

Katajala, Kimmo Nälkäkapina - Veronvuokraus ja talonpoikainen vastarinta Karjalassa 1683-1697 (1994)

Katajala, Kimmo Suomalainen kapina - Talonpoikaislevottomuudet ja poliittinen kulttuuri Suomessa Ruotsin ajalla (n. 1150-1800) (2002)

Knuutinen, Reijo Hyvät pahat verot (2017)

Kujala, Antti Voudintileistä veroparatiiseihin (2021)

Laukka, Petri Kekkoslovakian kuninkaat - Hurriganes 1970-luvun suomalaisen kulttuurin tuotteena, tekijänä ja nostalgiana (2013)

Lindgren, Juha Maaverojen ja yritysverotuksen kehitys - Veroparseleista ja suostunnasta kansainväliseen verokilpailuun, Verotus 1865-2015 Näkökulmia suomalaiseen verotukseen, Verohallinnon julkaisu (2015) Linnakangas, Esko Urheilu ja verotus - Oikeustieteellinen tutkimus (1984) Linnakangas, Esko Verojen kohtuullistaminen (1987)

Linnakangas, Esko Elokuvaverotus (1990)

Linnakangas, Esko KHO:n oikeustapausselostuksia, Tekijänoikeuspalkkioiden henkilöllinen kohdistaminen - veron kiertäminen, Verotus 2001 s. 436 ss. 
Linnakangas, Esko Väkivalta, seksi ja rikokset verotuksessa, Terttu Utriaisen juhlakirja (2006) s. 331 ss.

Linnakangas, Esko Suomen kulutusverotuksen historia ja veneveron haaksirikko (2017)

Linnakangas, Esko Korvamerkkiverot, vapaaehtoiset verot ja veron kirnuaminen, Defensor Legis 4/2018 s. 656 ss.

Linnakangas, Esko Kansanvalta, ikä, vero-oikeus (2020)

Linnakangas, Esko - Immonen, Raimo - Puronen, Pertti Verotuskäytäntö 1997

Linnakangas, Esko - Immonen, Raimo - Puronen, Pertti Verotuskäytäntö 1998

Linnakangas, Esko - Juanto, Leila Verojen historia - Synty, kehitys, kuolema, ylösnousemus, reinkarnaatio (2016)

Linnakangas, Esko - Juanto, Leila Synti- ja haittaverokirja - Anekaupasta paheveroihin ja kompensaatiomaksuihin (2020)

Lähde, Heikki K. Manttaali - miesluvusta tuottavuuden mitaksi, Maankäyttö $2 / 2013$

Malmgrén, Marianne - Myrsky, Matti Kansainvälinen henkilö- ja yritysverotus (2017)

Malmgrén, Marianne - Myrsky, Matti Elinkeinotulon verotus (2020)

Marcato, Silvia A sociological approach to The Beatles' protest songs (2012/2013)

Marjamäki, Tuomas Hän hymyilee kuin Mikko (2020)

Mäki, Teemu Miksi valtion pitäisi tukea taidetta? Taiteilijalehti 20.8.2018

Nurkkala, Tarja Kirjan käsite arvonlisäverotuksessa, Verotus 1996 s. 284 ss.

Puronen, Pertti Lahjaverotuksen ala (1990)

Puronen, Pertti Perintö- ja lahjaverotus (2015)

Rautiainen, Pauli Taiteen vapaus perusoikeutena (2007)

Rautiainen, Pauli Suomalainen taiteilijatuki - Valtion suora ja välillinen taiteilijatuki taidetoimikuntien perustamisesta tähän päivään (2008)

Rautiainen, Pauli Kuvataiteilijan oikeudellinen asema - Ammattimaista taiteellista toimintaa rajoittava ja edistävä oikeussääntely (2012)

Rekola, Aarne Tulo- ja omaisuusverolaki (1947)

Räbinä, Timo - Myllymäki, Janne - Myrsky, Matti Henkilökohtaisen tulon verotus (2019)

Räbinä, Timo - Myrsky, Matti-Myllymäki, Janne Verotusmenettelyn perusteet (2017)

Seppälä, Suvianna Viljana, nahkoina, kapakalana - Talonpoikien maksamat kruununverot Suomessa vuosina 1539-1609 (2009)

Stenman, Joonas Taiteen julkinen rahoitus (2012)

Söderlund, Seppo Oikeus ja kohtuus verotuksessa - Oikeustieteellinen tutkimus verovelvollisen oikeudesta saada ja veroviranomaisen velvollisuudesta myöntää harkinnanvaraisia veronhuojennuksia (2009) 
Taina, Jesse Keywords in heavy metal lyrics (2014).

Tarkiainen, Kari Ruotsin itämaa - Esihistoriasta Kustaa Vaasaan (2010)

Tikka, Kari S. Veron minimoinnista (1972)

Tunturi, Markku O. Miniosakeyhtiön sivuuttamisen veroseuraamukset, Verotus 1993 s. 433 ss.

Vilkuna, Kyösti Veto, veikka ja maanrahat, Virittäjä 1959 s. 452-465

Virtaranta, Pertti Amerikansuomen sanakirja (1992)

Voionmaa, Väinö Suomalaisia keskiajan tutkimuksia (1912)

Wikström, Kauko Valtion tuloveron rakenne - Tutkimus tuloveron rakentees-

ta ja sen peruspiirteiden historiallisesta kehityksestä (1985)

Ylikangas, Heikki Nuijasota (1977) 


\section{Oikeustapaushakemisto}

Korkein hallinto-oikeus

1952 II 763

1960 I 13

1961 T 602

1965 II 555b

1965 II 560

1966 II 555

1970 II 512

1975 T 3262

1979 II 553

1980 II 614

1981 II 597

1982 II 503

28.9.1982 T 4277

1983 II 602

1983 T 4696

1985 II 506

1986 II 549

1986 T 4724

1987 B 570

1988 B 538

1989 B 522

25.10.1990 T 3642

1992 B 515
1993 B 516

124

1994 B 549

165

$\begin{array}{rlr}126 & 21.1 .1997 \mathrm{~T} 65 & 141 \\ 19,196 & 1997 \mathrm{~T} 155 & 165 \\ 127 & 1997 \text { II 532 } & 120 \\ 125 & 1997 \mathrm{~T} 1820 & 165 \\ 122 & 24.11 .2000 \mathrm{~T} 3033 & 168 \\ & & 236\end{array}$

125

$122 \quad 2001 \mathrm{~T} 1256$

$145 \quad 14.2 .2003$ T 342

208

$141 \quad 2004: 5$

$127 \quad 2004: 55$

2008:6

169

167

193, 196

163

164

$183 \quad 2012: 5$

165 2016:5

206

195

206

158

146

2017:93

139

15.2.2019 T 546

203

183

127

127

146

127

Keskusverolautakunta

1989:279

127

1990:441

159

127

1993:313

122

160

153

122 


\section{Teoshakemisto}

A

Aarretta etsimässä 53

An Act of Conscience 40

A Taxing Woman 46

After Taxes 70

Arvaamaton arvonlisävero 47

Artturi Robotti levitoi 87

Arvonlisäveron mekin ansaitsem-

me 91

Avoveteen 154

\section{B}

Baden-Baden 98

Balladi toveri Viljasesta 67

Barrikadimarssi 67

Blank Mafia 72

1040 Blues 71

Boston Tea Party 65

\section{D}

Darling Buds of May 46

Death \& Taxes 73

Der Steuersong 110

Diktaattorimies 99

Don't Pay the Poll Tax 106

E

Ei aina voi olla joulu 101

Ei muuta keinoa 98

Ei Voi Laittaa Verotukseen 104

Eikä me olla veljeksiä 83
El impuesto 111

Eniten vituttaa kaikki 99

Erottamattomat 86

Erämaan taistelu 43

Että hyvät voittaisi 87

$\mathbf{F}$

Flow So Sick 74

G

Get Drunk and Do Your Taxes 73

Get Out! 74

Gulliverin retket 49

H

Haistakaa paska koko valtiovalta 82

Hala! 101

Hellaan laakeri 154

Herra Huu - Ei toivottu lastenlaulu 102

Hopearahan kertomukset 48

Hovin Inkeri 43

Huss ja Andersson 93

I

I Committed Tax Fraud 74

I'm No Communist 69

I'm paying taxes but what am I

buying? 70

Ideology 78 
Ihminen on selviytyjä 87

Ilkka 58

Iltapäivän aurinko 76

Iltapäivää 75

Isojako 87

J

Jätkät senkun porskuttaa 86

K

Kalevala 57

Kansainvälinen 66

Karhunpyynti 154

Karhutaan 81

Kingpin 74

Kirotkaamme vanha maailma 66

Koetalo 42

Koiraverohelvetti 91

Kolme pikku miestä 67

Krötenwanderung 55

Kummeli 56

Kun ei rahat riitä 81

Kun iso joki tulvii 86

Kunnioittaen 44

Kunnollinen tullimies 100

Kätten työtä 67

Köyhälistön marssi 67

L

Lahjomattomat 45

Lalli 56

Laulu 20 perheestä 67

Laulu Laukon häädöistä 67

Laulu II maailmansodasta 67

Laulu punaisesta sydämestä 67

Lauluja verotuksesta 91

Lenin-setä asuu Venäjällä 67

Leon McDuff 70

(Let Me Flip Your) Taxes 74

Lisää veroja (niille) 104

Livets skatt 108

Lukemisia lapsille 48

Löysäläisen laulu 59
M

Maailman onnellisin kansa 234

Make Me Laugh 70

Marseljeesi 65

Masturbaatio ilman käsiä 90

Matin muijan kuolema 78

Meni rahahommat pieleen 82

Menolippu 96

Merkit 101

Mies, joka ei osannut sanoa ei 44

Misty 74

Mitä jos ne tajuu 100

Molskis, sanoi Eemeli 44

Myö ei makseta veroja 102

N

Nalog 107

Nikke Knatterton 55

Noobie Taxes 73

Nuestros impuestos 111

Nuijamiesten marssi 64

0

Oi ihana toukokuu 46

Oi, kallis Suomenmaa 98

Oikeuden puolesta 46

Olen suomalainen 99

Ol' George Stopped Drinkin'

Today 70

Olithan kerran minun 92

On the Basis of Sex 46

Orjan poika 58

$\mathbf{P}$

Palkat, verot ja elintasoerot 104

Perustuslaillinen riemumarssi 67

Pieni Huijaus - Kuutamokeikkaa 102

Pimps Don't Pay Taxes 71

Podatek Od Miłości 36

Poliittisesti Correcti 104

Poll Tax Song 106

Pomperipossa i Monismanien 50 
Punainen viiva 43

Punakaartin marssi 67

Punaorvon vala 67

Putous 55

Pyhän Henrikin surmavirsi 56

Päivit tua menee 103

$\mathbf{R}$

Rahan takii 104

Raskaasti verotettu laulu 91

Ravintola Wunderbar 47

Reki Balboa 101

Rekkamies 101

Remonttihommia 60

Riistäjän lait 67

Robin Hood 45

\section{S}

Sales Tax On The Woman 69

Sam 73

Samle skatter 108

Seitsemän veljestä 37

Simo Hurtta 43

Simo Hurtta ja Anna 43

Simo Hurtta ja isoviha 43

Simo Hurtta ja kultainen pikari 43

Sjung språket 110

Skattevisan 109

Skattsången 110

Sossu-Possuilua Finlandiassa Totuus punataudista! 89

Spede-show 56

Sunny Afternoon 75

Suomen poliisit 89

Suomi-neidon elätit 91

Suuri Huuhaakirja 67

Syntax 74

Syyttäjä 46

\section{T}

Taistojen tiellä 67

Take This Job And Shove It 72

Take This Tax and Shove It 72
Talking with the Taxman About Poetry 78

Talonomistaja 101

Tango fasismin ja kapitalismin suhteesta 67

Tax Exile 70

Taxes 73

Taxman 77

Tesomajärvelle 100

The Lottery 71

The Prayer 71

The Tax Collectors 40

The Tax Inspector 46

Tonni 102

Transitmies 99

Tuhma tullimies 100

Tullimies 100

Tullivapaa avioliitto 44

Tuulen viemää 45

Työväen marssi 67

Tästäkö minä maksan 87

U

Ulkomaille 103

Uusfasismia vastaan 85

Uusi Paavo 81

V

Vakuutuskuori 104

Vanha salakuljettaja Laitinen 101

Vapauden kaiho 67, 233

Veli, sisko 67

Veroblues 91

Verojenkka 92

Verokarhu.fi - Verotuksen alkeet 54

Verolaulu 88

Verolippu 96

Veron hetki on kallis 94

Veronkantaja 41

Veronkierto-Vilkku 101

Veropakolaiseksi Somaliaan 96

Veroparatiisi 90, 97

Verorock 89 
Veroswing 91

Verot ja kuolema 95

Verotango 93

Verotoimiston huorat 89

Verottaja ja vouti 83

Verotus 103

Verotus keveni 62

Verotus on kauhistus 80

Verovalitus 80

Vicky Lee 88

Viiden vuoden päästä 88
W

Western World 73

$\mathbf{Y}$

Yhdentoista virran maa 6,85

You Make Me Like Charity 71

Ä

Älä nuolaise 44

Ära maksa maksu! 108 


\section{Taiteilijahakemisto}

A

Aalto, Alvar 42

Aaltonen, Ilkka 79

Aaltonen, Wäinö 41

Aho, Juhani 229

Alatalo, Mikko 6, 69, 85

Anal Paprika 102

Anthrax 70

B

Baez, Joan 80

Baltzar, Veijo 220

B.o.B 72

Barz, Dr. 73

Bates, Herbert Ernest 46

Bragg, Billy 78

Brown, James 70

Brown, Terrell 71

C

Caesar, Daniel 73

Caiborne, Shane 80

Carey, Peter 46

Cash, Johnny 69

2 Chaiz 73

Changemaker 109

Chaos New Money 74

Chisu 98

Chydenius, Kaj 92

Cooper, Myrtle 69

Cray, Robert 71

\section{D}

Davies, Ray 75

Degeyter, Pierre 66

Dixon, Dorsey M. 69

Dowler, Damon 77

Døt Kb 74

E

Ecker, Horst 53

El Tri 111

Elastinen 102

Engberg, Gabriel 42

Engel, C. L. 228

Epps, Tauheed 73

Esko, Matti 101

$\mathbf{F}$

F.U.2-02 70

Finneide, Svein 108

G

Ginsburg, Ruth Bader 46

Goodman, Irwin 79, 80, 102, 233

Graham, John 47

Gyllström, Katy 54

H

Hakaniemi, Aleksanteri 100

Hammarberg, Antti 80

Hankonen, Petri 97

Harrison, George 77 
Hauta-aho, Jussi Tapani 104

Heinivaho, Matti 220

Helenius, Kari 220

Hellaakoski, Aaro 60

Heller, Fred 72

Hendryx, Nina 70

Hilipiliboys 96

Holmberg, Kalle 220

Hovi, Seppo 220

Huge L 102

Huhtala, Timo 55, 99

Hummeripojat 79

Huusko, Kimmo 102

I

Iglu 91

Itami, Juzo 46

Ivalo, Santeri 43

J

Janosch 53

Jarva, Risto 44

Johnston, Karen Michelle 106

Jones, George 70

J-Zone 71

Juju 102

Julle 96

Järnefelt, Arvid 229

Järvenpää, Veli-Matti 78

K

Kajanus, Robert 229

Kallio, Onni 60

Kanniainen, Vesa 62

Karjalainen, J. 78

Kayah 36

Keim, Walther 55

Kepplerus, Anni 43

Kianto, Ilmari 43

Kinnunen, Heikki 92

Kivi, Aleksis 37, 86, 229

Klamydia 90, 97, 101

Koivisto, Tapani 83

Koivula, Pertti 91
Kokkonen, Ere 220

Korpela, Jukka K. 67

Korzhukov, Sergey 107

Koskenniemi, V. A. 64

Kottonmouth Kings 71

Kramsu, Kaarlo 58

Kube 104

Kujala, Juho 67

Kummeli 56

Kunnas, Mikko 54

Kuula, Toivo 64

Kuusela, Lasse 80

Kuusinen, Otto Wille 66

Kylävaara, Ilkka 92

Kätkävaara, Julle 96

L

Laiho, Kimmo 102

Lane, Mike 107

Lavi, Veikko 79, 91

Leiber, Jerry 70

Leino, Eino 43, 58, 85

Leino, Kasimir 229

Leinonen, Seppo 53

Les Inconnus 110

Leskinen, Juice 47

Lesopobal 107

Liebkind, Johnny 75

Lindgren, Astrid 50, 77

Lipsanen, Ilkka 220

Loiri, Vesa-Matti 222

Loiriplukari 104

Lulu Belle 69

Lundegren, Yrjö 154

Lönnrot, Elias 57

M

Massys, Quinten 40

Mattsson, Jan 110

Maustetytöt 82

Mc Mane \& Sarkastinen 103

Miettinen, Karri Pekka Matias 101

Mitchell, Margaret 45 
Mumford, Jay 71

Mäki-Lohiluoma, Jouni 99

N

Narri 104

Neeras, Maja 108

Niemeläinen, Ilmari 154

0

O blivion, Monty 73

Oksanen, Ritva 220

P

Paakkari, Katri 55

Pakkala, Teuvo 229

Palaste, Onni 43

Paleface 79, 101

Parker, Junior 77

Pasanen, Spede 56

Pax Americana 104

Perttu, Tapani 220

P-Funk North 74

Pihlajamaa, Lasse 220

Pink Floyd 70

Portion Boys 103

Pottier, Eugène 66

Psychoterror 108

Pylkkänen, Tauno 43

Pöysti, Lasse 220

R

Ranin, Matti 220

Ranta, Ville 53

Rebel G 74

Reponen, Pertti 80, 104

Rinne, Harri 85

Rislakki, Ensio 44

Robin 76

Roine, Eila 220

Roosberg (s. Sundberg), Christel 98

Roget de Lisle, Claude Joseph 65

Runeberg, J. L. 108, 228

Ruonansuu, Jope 56
Ruudolf 101

Räyhänhenki 100

S

Saalmann, Klaus 55

Salmi, Vexi 81

Sariola, Mauri 43

Sarisalmi, Julius 102

Sarpila, Antti 92

Scotty 69

Shocked, Michelle 106

Sibelius, Jean 229

Silvo, Satu 92

Simmonds, Ashton Dumar Norwill 73

Simmons, Bobby Ray Jr. 72

Simonen, Seija 220

Sipe 100

Sirola, Yrjö 66

Sleepy Sleepers 89

Snellman, Timo 60

Somerjoki, Pauli 97

Spekti 99

SRKMXTP3! 103

Sund, Viktor 60

Suomalainen, Kari 53

Suotaunot 100

Swift, Jonathan 49

Särkkä, T. J. 220

T

Taivainen, Kalle 104

Tanich, Mikhail 107

Tapio, Kari 99

Tax Exiles 70

Taylor, Edward 47

TEA 70

The Beatles 77

The Beef Boys 74

The Exploited 106

The Granite Countertops 74

The Kinks 75

The Knife 71

The New Lost City Ramblers 69 
The Nitty Gritty Dirt Band 70

The Recalculating 73

The Sensational Alex Harvey Band 65

The Stanfields 73

Topelius, Zacharias 48

Tuisku, Antti 104

Tukiainen, Aimo 41

Tuomari Nurmio 234

Turf 111

Turo's Hevi Gee 96

Tuukkanen, Kalervo 154

Tynni, Aale 154

Töyssy, Mikko 55

U

Uusitalo, Kari 220
V

Vainio, Juha "Watt" 79, 88, 101

Verhoog 74

Veronalainen, Paolo 41

VEROT BOYS 92

Viilunk, Urmas 55

Vilperin perikunta 91

Virtanen, Eino 40, 80

Visanti, Matti 42

W

Wesley, Fred 70

Wheeler, Billy Edd 70

von Wright, Ferdinand 228

von Wright, Magnus 228

WSHH Heatseekers 73

Wuolijoki, Sulo 66

$\AA$

Åttopojat 100 


\section{Asiahakemisto}

\author{
A \\ aineettomat hyödykkeet 122,138 , \\ 140, 185, 194, 236 \\ ajallinen kohdistaminen 138 \\ alennettu verokanta 212 \\ alkoholi 79, 98 \\ ansiotulot 115, 121, 137, 139, \\ 142 \\ anteeksianto 47, 55, 221 \\ apurahat 123 \\ arvonimivero 219 \\ arvonlisäverotus 202 \\ autovero 98 \\ avainhenkilöt 181
}
B
brittiläiset veroprotestilaulut 75
C
country 68
D
duralex-ilmiö 221

\section{E}
edustusmenot 186
e-kirja 47
e-urheilu 153
elinkeinotulo 120, 146, 183, 207
elokuvat 42
elokuvatuotantotuki 143

elokuvaverotus 197

ennakkoperintä 29,32

esiintymispalkkiot 204, 215

espanjankieliset verolaulut 110

H

harakka 54

harrastus 21

henkilökuntaetu 129

henkilöllinen kohdistaminen 155

henkilöyhtiöt 160

henkivero 104

hetekavero 61

huviverotus 197

I

ihmisvero 57

irtolainen 60

J

jaksottaminen 138

K

kaksinkertainen verotus 172

kansanlaulut 78

kantri ks. country

kiinteistövero 118

kilpailupalkinnot 127

koiravero 60

koti-irtaimisto 192

Kristus-ratkaisu 158 
kulttuuritilaisuudet 214, 215 kulumaton käyttöomaisuus 186 kulutusverotus 33

kunnallisverotus 29, 114, 154

kuunnelma 47

käsitetaide 20

käyttöomaisuus 185

L

lahjaverotus 190

lahjoitusvähennykset 187

lapsettomuusvero 107

laulut 64

linnaleiri 64

luontoistalous 92

lähdevero 180

löysäläinen 60

\section{M}

maksu 27

marginaaliverotus 211

menovaraus 147

metsästysvero 92

muistomerkit 40

myyntimaa 215

mätkyt 96

\section{N}

noise-musiikki 91

norjankieliset verolaulut 108

nuijasota 42, 58, 64

näytelmät 42

o

osakeyhtiö 161

P

palkinnot 125

palkkiosta luopuminen 157

patsaat 40

perintöverotus 190

perustuslaki 25

pilapiirtäjä 53

piirrokset 53 pirkkalaiset 41

pohjoisamerikkalaiset laulut 68

poll tax 104

progressio 154

puhelaulu 69

puu ja hedelmät -oppi 157

pääomatulot 121

\section{$\mathbf{R}$}

rahastointi 149

rakennukset 40

ranskankieliset verolaulut 110

rap 68

rikossarja 42

rojaltit 176

romaanit 42

runot 56

ruotsinkieliset verolaulut 108

räppäys 68

S

sadut 48

saksankieliset verolaulut 110

sarjakuvat 53

sisäänpääsymaksut 214

sivuuttaminen 160,164

sketsit 55

stipendit 123

suhdetoimintamenot 186

suomalaiset verolaulut 78

sänkyvero 61

T

taide 19

taide-esineet 117, 186, 192, 211, 213, 217

taidelainsäädäntö 25

taidemenot 185

taidesäätiöt ja -yhdistykset 191

taiteenlaji 19

taiteilija 21

taiteilija-artikla 174

taiteilijarahasto 149

taiteilijatili 147 
tappiontasaus 142

taulut 40, 193

tekijänoikeudet 26, 193, 204, 213

tekijänoikeusjärjestöt 213

tekijänoikeustulot 168

tukijat 182

tullit ja tulliverotus 33, 100, 216

tulolajit 121

tulolähde 120

tulon veronalaisuus 120

tulonhankkimismenot 134

tulontasaus 144

tuloverotus 113

tunnustuspalkinnot 125

turkisverot 92

työväenlaulut 64

U

urheilu 23

V

vaihto-omaisuus 185

vajaaverotus 172

vallankumouslaulut 64

vanhentuminen 221

vapaaehtoinen verovelvollisuus 203 varallisuusverotus 115

Veikkaus 184

verokanta 212

verokarhu 53

veron kiertäminen 155

veron käsite 27,35

veropakolaisuus 96

veroparatiisi $87,90,95,97,103$

veroparseli 57, 92

verosopimukset 173

verosuunnittelu 155

viihdetaiteilija 22

vouti $29,37,83$

välillinen verotus 33

välitön verotus 28

$\mathbf{Y}$

yleishyödylliset yhteisöt 191

Yleisradio 99, 184

Ä

äänikirja 47

Ö

örinä 47 
Kirjassa selvitetään verotusteemaa ja sen kehitystä tauluissa, patsaissa, romaaneissa, elokuvissa, saduissa, piirroksissa ja runoissa sekä erityisesti protesti- ja muissa lauluissa. Käsittelyssä on suomalaisten taiteilijoiden teosten lisäksi ulkomaista aineistoa varsinkin USA:sta,

Britanniasta ja Ruotsista, mutta myös esimerkiksi Norjasta ja Saksasta.

Tutkimuksen juridisessa osassa tarkastellaan, miten taiteet on otettu huomioon verolainsäädännössä sekä oikeus- ja verotuskäytännössä. Laajimmin analysoidaan tuloverotusta ja siihen liittyviä kysymyksiä. Tuloverotuksen lisäksi mukana ovat perintö- ja lahjaverotus, huvi- ja elokuvaverotus, arvonlisäverotus, tulliverotus ja arvonimivero. Kirjassa arvioidaan myös taideverotuksen tulevaisuutta.

Kirjassa on asiahakemiston lisäksi teos- ja taiteilijahakemistot.

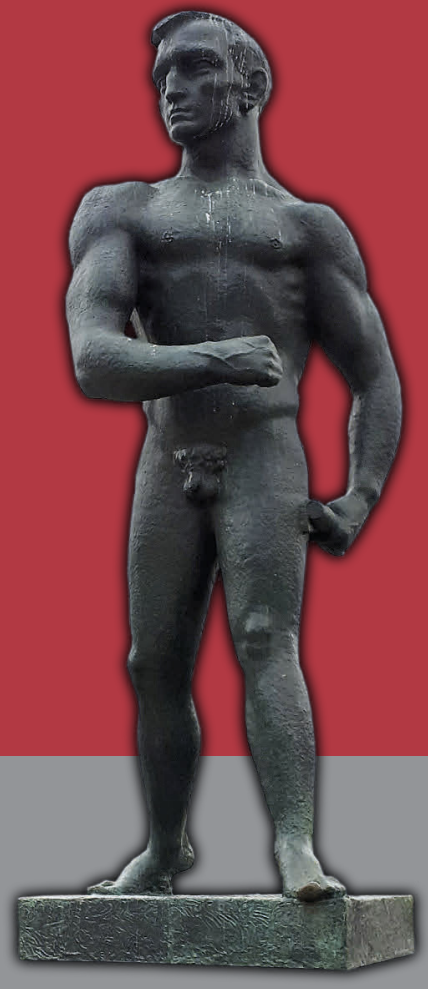

